Universidade de Brasília

Instituto de Artes

\title{
OS CONTADORES DE HISTÓRIAS NA CONTEMPORANEIDADE: da prática à teoria, em busca de princípios e fundamentos.
}

\author{
Ângela Barcellos Café
}

Orientação: Luciana Hartmann 
Ângela Barcellos Café

\section{OS CONTADORES DE HISTÓRIAS NA CONTEMPORANEIDADE: da prática à teoria, em busca de princípios e fundamentos.}

Tese apresentada ao Programa de Pós-Graduação em Arte do Instituto de Artes da Universidade de Brasília - PPG-IDA, para obtenção do título de Doutora em Arte.

Linha de Pesquisa: Processos Composicionais para Cena.

Orientadora: Prof. ${ }^{a}$ Dr ${ }^{a}$ Luciana Hartmann

Brasília - DF

2015 
Ângela Barcellos Café

\section{OS CONTADORES DE HISTÓRIAS NA CONTEMPORANEIDADE: da prática à teoria, em busca de princípios e fundamentos.}

Tese apresentada ao Programa de PósGraduação em Arte do Instituto de Artes da Universidade de Brasília como requisito para obtenção do título de Doutora em Arte na linha de pesquisa Processos Composicionais para Cena.

Orientadora: Prof ${ }^{a}$. Drª . Luciana Hartmann

\section{Banca Examinadora:}

Profa ${ }^{\text {. }}$ Dr ${ }^{\text {a }}$. Luciana Hartmann - (Orientadora)

Universidade de Brasília - UnB

Prof ${ }^{a}$. Dr . Gilka Girardello - (membro externo)

Universidade Federal de Santa Catarina

Prof. Dr. Celso Sisto - (membro externo)

Universidade Federal do Rio Grande do Sul

Prof ${ }^{\text {a }}$. Dr ${ }^{\mathrm{a}}$. Roberta Matsumoto - (UnB/IdA/CEN)

Universidade de Brasília - UnB

Prof. Dr. César Lignelli - (membro interno)

Universidade de Brasília - UnB

Prof ${ }^{-}$. Drª . Clarisse Costa - (suplente)

Universidade de Brasília - UnB

Brasília, dezembro de 2015 
Dedicatória.

A todos aqueles que no mundo de hoje encontram tempo para ouvir e/ou contar histórias, encantando pessoas e despertando encantamentos...! 


\section{AGRADECIMENTOS}

Agradeço em primeiro lugar aos meus pais: Adelmo de Moura e Silva Café por me inserir no mundo das artes, da sensibilidade, do respeito e observação; e Maria Helena Café, que contando histórias e brincando me ensinou a educar, reconhecendo o valor do outro, do diálogo, do espírito de liberdade que se conquista com a consciência da responsabilidade; aos dois especialmente, dedico essa tese, como retribuição à educação que me deram e fizeram de mim uma contadora de histórias, educadora e artista.

Ao meu querido esposo, Sérgio Duboc, agradeço o companheirismo de todos os momentos, nas lutas e conquistas cotidianas, sempre ao meu lado disposto a ajudar, repartir e servir com amor. Aos meus filhos agradeço o carinho e compreensão de não me deixarem desistir nos momentos mais difíceis. Com meus netos compartilho as histórias que fui descobrindo ao longo do processo, quando pude estar presente.

À minha orientadora fica a eterna gratidão por ter acreditado em minha capacidade, na relevância do tema proposto, aceitando e validando minha experiência pessoal, sendo a peça chave nas desconstruções necessárias para o alcance dos resultados conquistados. Ao mesmo tempo as correções atentas e minuciosas me ajudaram a reconstruir caminhos mais seguros.

Aos colegas de pós-graduação agradeço os desabafos, reclamações e brincadeiras, essa vivência maravilhosa de ser aluno que nos permite experiências inesquecíveis, em qualquer época da vida. Às queridas colegas mais de perto: Tânia Garsen e Janaína Melo por persistirem na amizade, solidariedade e ajudas até os últimos momentos, assegurando uma amizade eterna. À colega e amiga Luzirene Rego, agradecimentos especiais pela difícil tarefa de me socorrer na formatação e referências da edição final, e pelo apoio e amizade durante o período do curso. Às novas amigas contadoras de Brasília, Aldanei Menegaz e Ana Marize Pessoa que me socorreram com generosas conversas que muitas vezes me reorientavam, minha gratidão e amizade, regada de muitas experiências a serem compartilhadas.

Agradeço por fim, a todos aqueles que um dia pararam um momento para me ouvir contando histórias, àqueles a quem tive oportunidade de um dia ouvir uma história e dela participar, e, a todos aqueles que um dia contaram, contam ou passarão a contar uma ou muitas histórias, deixando encantamentos como rastros... 


\section{RESUMO}

A presente pesquisa se inicia com o problema: se sempre existiu o contador de histórias, por que as pessoas procuram por curso de contadores, assumindo não conseguirem 'contar uma história'? Ao estruturar minha experiência pessoal, de vinte anos ministrando cursos e oficinas e contando histórias para públicos distintos, chego aos princípios e fundamentos que elucidam a prática de um contador de histórias. Com o objetivo de contribuir para a ampliação da arte de contar histórias, conquistando mais contadores e ouvintes, o contexto e o sujeito da pesquisa foram definidos como princípios, nas relações entre cultura, educação e arte, e na definição do sujeito contador, descritos nos dois primeiros capítulos. Os outros capítulos esclarecem os fundamentos decorrentes dos princípios eleitos para o estudo, em razão da reflexão sobre as práticas já realizadas. Assim, a presença do contador envolve os seguintes fundamentos: memória, imaginação, emoção e espontaneidade, que atuam juntos na significação do conto durante a ação do contar. A escolha e preparação do conto são apontadas como fundamentos que se definem pelo conhecimento e autonomia sobre as definições e alternativas assumidas. E, por fim, o fundamento do autoconhecimento, para atender as necessidades do uso das técnicas da linguagem corporal, para cada texto. O levantamento desses princípios e fundamentos pode orientar a constituição de outros contadores, sem, contudo, oferecer um modelo pronto, que não leve em conta as individualidades e objetivos de cada contador.

Palavras chave: contadores de histórias; educação/arte; aprendizagem; escolha; linguagem corporal. 


\begin{abstract}
This research starts from the following question: as the storyteller always existed, why do people keep on looking for courses on storytelling, assuming that they cannot 'tell a story'? When structuring my personal 20-year experience of giving out courses, workshops and storytelling for different audiences I reached the principles and basis that elucidate the practices of a storyteller. Aiming at contributing to the broadening of the art of telling stories, reaching more storytellers and audiences, the context and subject of the research were defined as principles, within the relations between culture, education and art, and in the definition of the storyteller, described in the two first chapters.

The other chapters clear out the basis resulting from the principles elected for the study, resulting from the reflections over the practices already carried out. Therefore, the presence of the storyteller involves the following basis: memory, imagination, emotion and spontaneity that act together on the meaning of the story during the act of the telling.

The selection and preparation of the story are pointed out as bases that define themselves through the knowledge and autonomy about the assumed definitions and alternatives. And, at last, the bases of the self-knowledge in order to meet the needs for the use of body language for each text. The survey on these principles and bases may orient the constitution of other storytellers without, nevertheless, offering a ready model that does not take into account the individualities and objectives of each storyteller.
\end{abstract}

Keywords: storytellers; education/arts; learning; selection; body language 
Epígrafe

O segredo não é correr atrás das borboletas...

É cuidar do jardim para que elas venham até você.

Mário Quintana 


\section{Sumário}

INTRODUÇÃO.

CAPÍTULO 1 - O CONTEXTO DA PESQUISA - CULTURA, EDUCAÇÃO E ARTE: uma rede conceitual que envolve o contador de histórias.

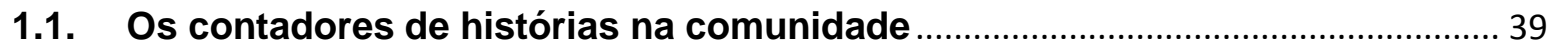

1.2. Os contadores de histórias na educação básica................................................. 43

1.2.1. A educação infantil e o contador de histórias.................................................. 46

1.2.2. 0 ensino de arte do $11^{\circ}$ ao $5^{\circ}$ ano do ensino fundamental..................................... 52

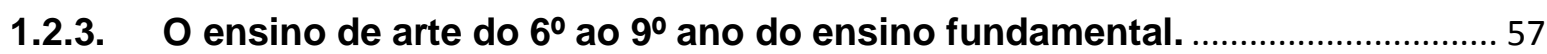

1.2.3.1. O contador de histórias no ensino médio. ...................................................... 63

1.3. O contador de histórias na formação do professor ............................................. 65

CAPÍTULO 2 - O SUJEITO DA PESQUISA - O CONTADOR DE HISTÓRIAS............ 70

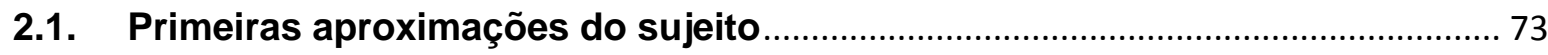

2.1.1. O contador de histórias na contemporaneidade …........................................ 76

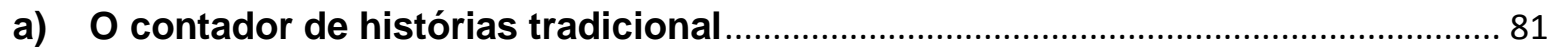

*Contos do Arco da Véia- pesquisa em Pirenópolis......................................................... 85

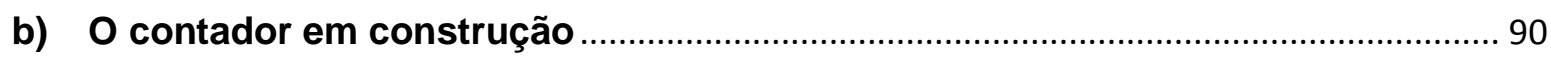

2.1.2. Um contador aprendendo com outro..................................................................... 96

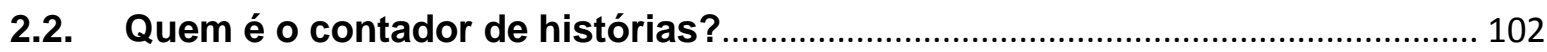

CAPÍTULO 3 - A PRESENÇA DO CONTADOR DE HISTÓRIAS ..............................109

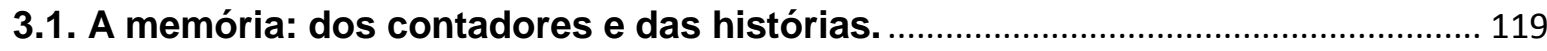

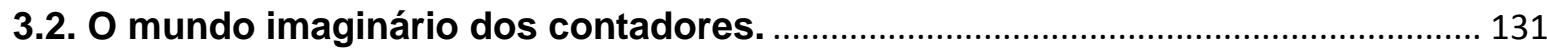

3.3. As emoções suscitadas pelas histórias ............................................................... 148

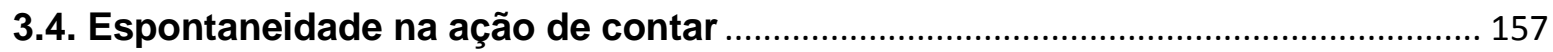

CAPÍTULO 4 - ESCOLHA E PREPARAÇÃO DO REPERTÓRIO …................................ 164

4.1. Definindo um repertório: um estudo de sociolinguística ..................................... 169

4.1.1 Contos populares: um repertório sem fim............................................................. 174

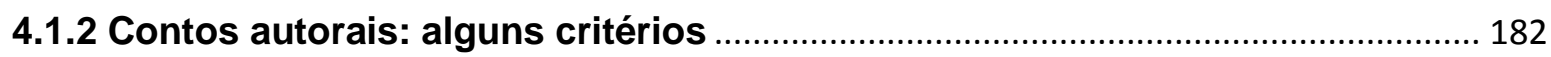

4.2. A preparação do conto - aproximações com o texto …………............................. 189

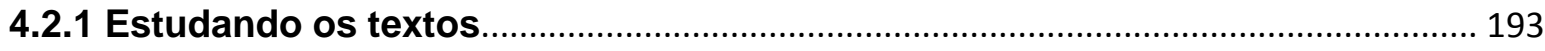

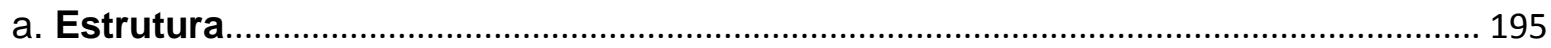

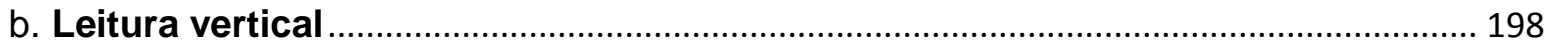

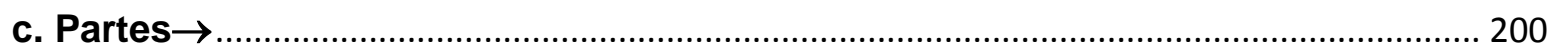


d. Sequência $\rightarrow$ 201

CAPÍTULO 5 - AS TÉCNICAS DA LINGUAGEM CORPORAL: do contador de histórias

5.1 - Oralidade

5.1.1 - A palavra: matéria prima do contador. 213

5.1.2 - A voz de quem conta histórias. 215

5.1.2.1. Parâmetros do som 217

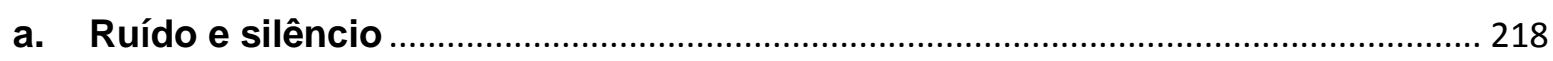

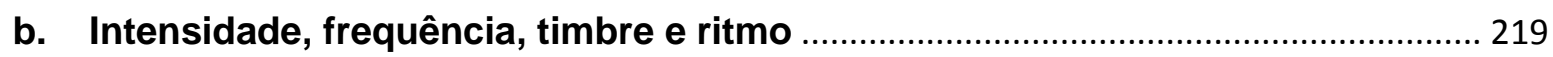

c. Contorno, direcionalidade e reverberação .............................................................. 222

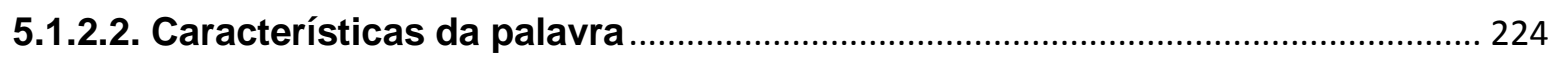

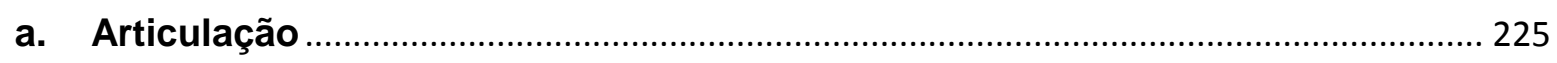

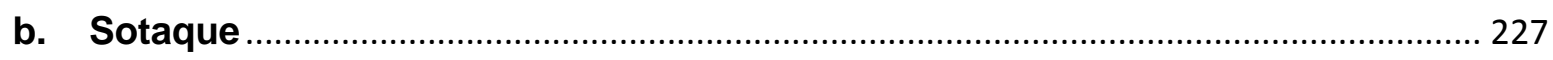

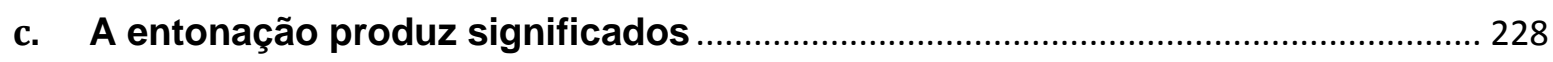

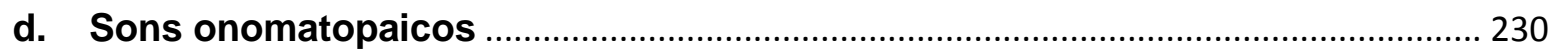

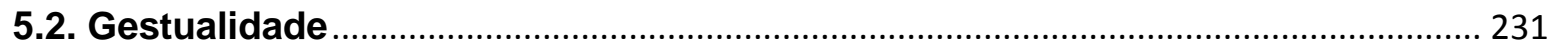

5.2.1. Gestos e movimentos na ação de contar ........................................................... 233

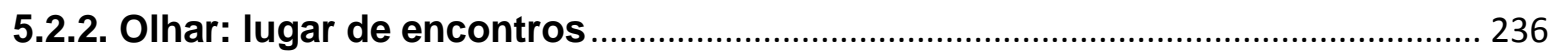

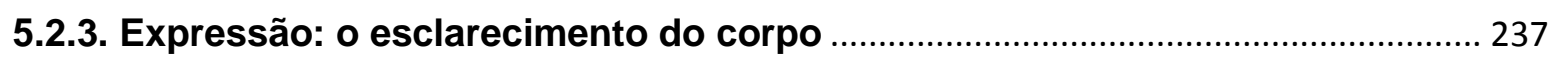

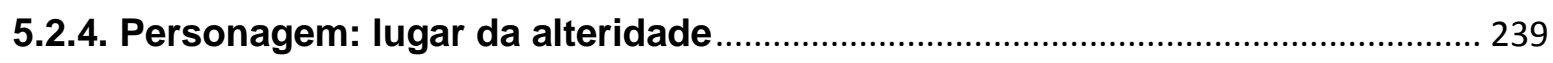

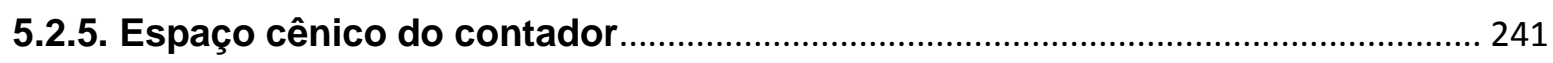

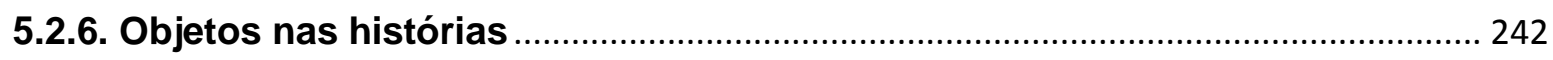

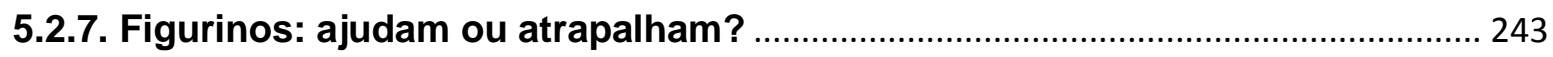

5.3. Ritmo

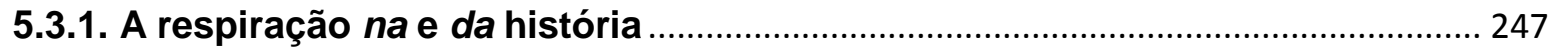

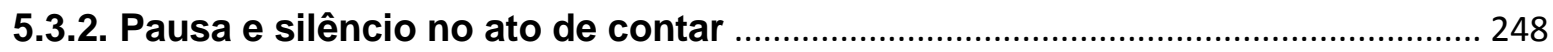

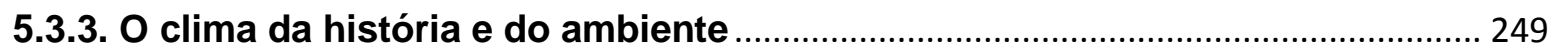

5.3.4 Ajustes finais na preparação e apresentação das histórias................................. 250

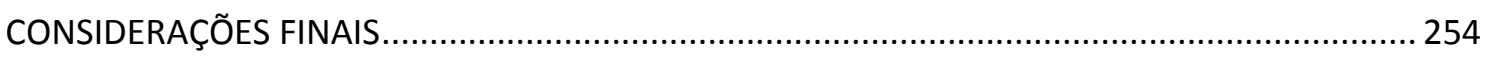

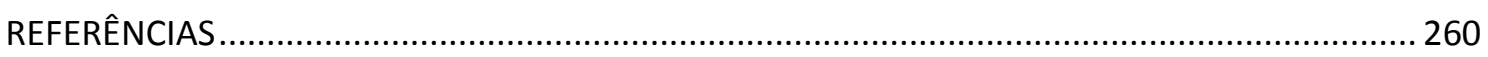

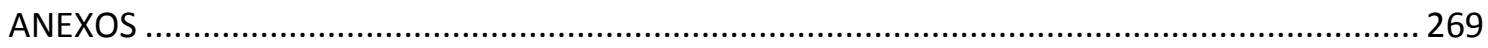




\section{INTRODUÇÃO}

Cada um carrega consigo uma sacola prá onde vão os personagens das histórias que ouvimos!

Só poderão sair de lá quando aquele conto for recontado...

(A sacola de couro - conto popular)

O contador de histórias passa a existir dentro de cada um, quando abrimos bem os ouvidos para um conto. E depois, quando encontramos outros ouvidos ávidos e curiosos por uma boa história, tendo a oportunidade de recontá-la. É quando cada um abre sua sacola e, à sua maneira e à sua escolha, 'conta um conto', suscita imagens e emoções nos ouvintes, permitindo o sonho e a fantasia. Tudo pode começar com um simples "Era uma vez...", ou qualquer outro início de história que, de imediato, convide o ouvinte a acompanhar as palavras cheias de encantamento, navegando nos significados, criando imagens, encontrando sentimentos, descobrindo sentidos, desvendando mistérios.

Os contadores de histórias se encontram presentes em uma infinidade de gerações que cresceram e se desenvolveram ouvindo e contando histórias, como meio de perpetuar sua cultura e, ao mesmo tempo, renovar e transformar suas ações. As alterações em uma narrativa são comuns, fazendo parte da dinâmica cultural em que os seres humanos estão inseridos, podendo ser observadas na criação, adaptação ou repetição de uma história. Em cada época e contexto, o contador as apresenta com traços diferentes.

Nos dias atuais, encontramos uma multiplicidade de contadores de histórias que empregam técnicas e estéticas variadas, atendendo a objetivos, espaços e públicos distintos. Alguns deles são reconhecidos, naturalmente, por sua comunidade, aprendendo o ofício no cotidiano da vida, com seus ancestrais, pela observação, repetição e recriação. Esses narradores vêm se perpetuando e, ao mesmo tempo, resignificando sua arte de contar histórias, de acordo com as transformações de seu tempo e de sua cultura. Por volta da década de 1980, em vários países, houve uma recuperação na valorização e no desenvolvimento da arte de contar histórias, por meio de formações específicas de contadores. Começaram a 
aparecer oficinas e cursos de contadores de histórias, formando um movimento ${ }^{1}$ desses 'novos' contadores, em bibliotecas, escolas e outras instituições, fossem elas educativas ou não.

Que movimento seria este? Acontece também no Brasil? Quais áreas estão envolvidas? De qual contador de histórias estamos falando? Quem é esse contador de histórias na contemporaneidade? Existem tipos diferentes de contadores de histórias? Como isso tudo começou? Se o contador de histórias sempre existiu, ou existe desde os tempos mais remotos, porque as pessoas sentem necessidade de procurar por cursos de contadores de histórias? Qualquer um pode ser contador de histórias? Para ser contador é preciso participar de alguma formação? É possível construir ou formar um contador de histórias?

Essas questões mostram tanto a existência, quanto apontam a consistência do objeto de estudos que me proponho a investigar e teorizar, na intenção de entender como se dá a construção/formação do contador de histórias, na contemporaneidade. Uma pesquisa feita de experiências vividas, analisadas e refletidas, abarcando emoções e imagens construídas, ao longo dos últimos vinte anos, contando histórias e formando contadores em oficinas e cursos, para alunos de áreas distintas, com idades e objetivos variados.

Refletir a própria experiência, buscando um corpus teórico que subsidie a gênese desse contador de histórias na contemporaneidade é, então, o foco central desta pesquisa, que tem como base a descoberta de um narrador oral ${ }^{2}$ que considere as possibilidades da arte educação como fonte de transformações significativas. A busca por várias áreas do conhecimento, como artes, antropologia, filosofia, letras, pedagogia/educação, história oral e psicologia, se justifica pelas múltiplas possibilidades que o objeto suscita em sua averiguação, por sua constituição. Mas é mais especificamente nas artes que esta pesquisa encontra maior contribuição teórica, uma vez que, para além das opções estéticas, o contador se apropria de uma linguagem corporal e textual, que também pode ser explorada

\footnotetext{
${ }^{1}$ Movimento observado em alguns países na Europa, na África e nas Américas. No decorrer da tese serão apresentados exemplos de projetos e contadores de vários desses lugares. Considero como movimento, com base nas conquistas de políticas públicas que começam a colocar o contador de histórias como destinatário de recursos para projetos específicos, em níveis internacional, nacional, estadual e municipal.

${ }^{2}$ Narrador oral é um termo emprestado por Francisco Garzón Céspedes, da Cátedra Ibero-americana Itinerante de Narração Oral Cênica (CINOE), retirado de material sobre Pedagogia teatral, publicado em 1994. O autor trabalha também com o termo narrador oral cênico, revelando as diferenças, destes com o ator de teatro. Nesta pesquisa, contador de histórias é tratado como sinônimo de narrador oral.
} 
nos estudos de formação do ator, aproximando esta pesquisa do campo das artes cênicas.

O uso da terminologia "arte de contar histórias" também é uma questão a ser considerada e analisada, uma vez que perpassa minha experiência, na intenção de ampliar diálogos e campos de ação dos contadores, entendendo de onde cada um fala. O que trago para compartilhar é minha experiência de arte educadora, cuja discussão de professor artista responde a multiplicidade do objeto que acolhe vários olhares, por sua característica plural. A luta pelo espaço de vivências e manifestações artísticas é o que dá sustentabilidade à minha luta pessoal, portanto, o olhar aqui presente encontra-se na arte.

O reconhecimento da importância desses estudos e práticas está presente em algumas Universidades, em áreas do conhecimento diversificadas, sobretudo aquelas que aceitam os saberes populares como legítimos. Pontualmente, alguns professores universitários ${ }^{3}$ vêm desenvolvendo essa prática em projetos de extensão e/ou pesquisa. Também começam a nascer disciplinas, na graduação de artes cênicas, seja de forma optativa ou obrigatória, que indicam o reconhecimento do trabalho do contador também para a formação do ator. Contudo, esta investigação, embora tenha foco na descoberta do contador de histórias, não se propõe a discuti-la na graduação de modo específico, embora envolva as experiências com alunos de graduação em projetos e disciplinas. Tampouco considera uma atividade direcionada exclusivamente para a infância, podendo ser utilizada para qualquer idade, com objetivos diversos, considerando com o repertório e com as técnicas, mais explorado no último capítulo. E, ainda que seja analisada como uma atividade educativa é na perspectiva de uma educação maior do que a escola, portanto, alcançando e ampliando espaços de atuação.

Para dar conta de abranger toda essa diversidade, considero importante situar o leitor, revelando como surgiu esta investigação. Entretanto, tal tarefa pede uma contextualização de parte de minha própria história, que, em muitos pontos, se funde com as experiências que estão aqui refletidas e analisadas. Esclarecer de onde falo elucida posicionamentos e embasamentos constituídos no percurso de

\footnotetext{
${ }^{3}$ Regina Machado (artes visuais; USP); Gilka Girardello (educação; UFSC); Gislayne Matos (letras; PUC - MG); Cleidna Landivar (escola de aplicação; UFG); Diane Valdez (educação; UFG); Eliana Yunes (letras; PUC - RJ); Luciana Hartmann (artes cênicas UnB - DF); Gisele Soares de Vasconcelos (UFMA).
} 
minha própria construção como arte-educadora e narradora de histórias, "de boca e de livro".

Filha de professores universitários ${ }^{4}$, com o pai professor de história da arte e mãe na filosofia da educação, tive a sorte de crescer em um ambiente de muitas histórias e muitas brincadeiras. O maior valor em minha casa era brincar e jogar, sem se importar com o resultado do jogo. Ninguém podia apelar quando perdesse. E fomos aprendendo que era normal perder, o gostoso era jogar, no meio de muita diversão, com seis irmãos e um monte de amigos e vizinhos. Casa cheia, sempre com alguém para compartilhar. Com meus pais, aprendi que educação é troca, e nunca saí de uma sala de aula, de uma sessão de histórias, ou de um simples diálogo, sem aprender algo novo. Ainda hoje, continuo com essa vontade boa de aprender mais! Acredito que a flexibilidade que acompanhou o contexto de minha educação familiar me ensinou a aceitar e compreender a diversidade como estímulo para a aprendizagem.

Com a vida cheia de surpresas e contratempos, somente aos 26 anos foi possível iniciar minha graduação. O curso escolhido foi Licenciatura em Educação Física, na Escola Superior de Educação Física de Goiás (Esefego) e, depois de trabalhar alguns anos para o Estado de Goiás, na Secretaria de Ação Social e na própria Esefego, fui convidada para compor a equipe técnica que abriu a Creche da Universidade Federal de Goiás - UFG. Meus maiores interesses, durante minha formação, se direcionavam, especialmente, para a criança e tudo que envolvia o jogo e a brincadeira: o corpo em movimento. Desde criança, sempre gostei de conviver com outras crianças e, embora eu tenha crescido, continuo a me sentir bem no meio delas, direcionando, sempre que possível, minhas atividades profissionais para essa convivência. A maior parte da minha vida foi, e ainda é, rodeada por muitas crianças e minha facilidade de envolvimento com elas acabou por direcionar minhas escolhas 5 .

Enquanto trabalhava na creche, fui selecionada em concurso para dar aulas de Educação Física para o ensino fundamental e médio, no Colégio de Aplicação da

\footnotetext{
${ }^{4}$ Meus pais migraram de Minas para Goiás, no início de suas vidas profissionais e fizeram família e nome em Goiânia e várias cidades do Estado de Goiás, sendo referência em arte e em educação, tendo recebido grandes títulos e homenagens, embora não tenham deixado registros escritos, embora não tenham deixado muitos registros escritos.

${ }^{5}$ Digo isso porque, em paralelo às atividades de formação profissional, de alguma forma sempre estive envolvida com a infância, fosse em animações de festa de aniversário, fosse em rua de recreio, colônia de férias, creches, entre outros projetos. Com isso, grande parte da minha experiência pode ser dirigida à pessoas que lidam com este público.
} 
UFG (escola em que eu havia estudado). Atualmente, esta escola é o CEPAE, Centro de Ensino e Pesquisa Aplicada à Educação ${ }^{6}$, onde lecionei por dez anos, entre 1992 e 2001. Nessa escola, tive muitas oportunidades de fazer pesquisa e descobrir o que é estudar. E gostar.

Nessa época, mais precisamente em 1993, nasceu o grupo Gwaya Contadores de Histórias/UFG, do qual fiz parte, durante doze anos. É um projeto de Extensão da UFG, uma vez que, nesta escola (CEPAE), todos os professores são concursados em nível superior, tendo todas as atribuições do professor universitário: ensino, pesquisa e extensão, sendo, ainda, responsáveis pelo acompanhamento dos estágios dos institutos da UFG. O grupo Gwaya foi objeto de estudo de meu mestrado, defendido na perspectiva do Lazer, na Unicamp, em 20007. Hoje, são outras pessoas, outros caminhos... Mas, as histórias continuam!

Nesta escola da UFG, onde tudo começou, minhas aulas de educação física eram 'aulas historiadas', método que desenvolvi para exercitar tarefas psicomotoras com as crianças, sem que elas percebessem que estavam fazendo ginástica. Tudo era em forma de uma grande brincadeira, pois considerava que brincar era o mais importante, na lida com os alunos de 6 a 10 anos. As histórias, muitas vezes, eram escolhidas no planejamento semanal, com os outros professores. Nessa época, muitos docentes desta escola faziam parte do Gwaya e, juntos, estudávamos a literatura infantil e juvenil, autoral e popular e a importância dessas histórias para as crianças.

A arte sempre rondou minha infância e toda a minha vida, em minha casa e nos lugares que frequentávamos. Desde pequena, tive interesse em passear pelos livros de arte da biblioteca de minha casa, nada pequena, tendo contato com registros de muitas obras de arte, de épocas e contextos diferentes, construções da humanidade. A forma com que meu pai explicava sobre uma obra de arte era diferente da forma dos professores que encontrei, pois ele se limitava a esclarecer o contexto de criação daquela obra. Muito cedo, aprendi que a interpretação, seja de que modalidade for, era livre, do jeito que o espectador quisesse entender e que, de

\footnotetext{
${ }^{6}$ Antigo Colégio de Aplicação, escola de ensino básico que nasceu como departamento da Faculdade de Educação da UFG e, hoje, é unidade independente, acolhendo os estágios dos cursos de licenciatura e oferecendo pós-graduação à distância, além de todo o ensino fundamental e médio.

${ }^{7}$ Com publicação em 2005, com o título: Dos contadores de histórias e das histórias dos contadores.

${ }^{8} \mathrm{Na}$ Educação Física, nunca encontrei bibliografia que identificasse essa minha prática. Quando iniciei os estudos dos jogos dramáticos e teatrais, me deparei com o autor inglês do Drama Infantil, Peter Slade (1978), descobrindo que, intuitivamente, as minhas aulas de corpo se aproximavam intensamente das ações dramáticas propostas por este autor, apenas meu foco na época era outro.
} 
certa forma, todas as interpretações encontram ressonâncias nas experiências pessoais de cada um. E, assim, fui aprendendo a importância de considerar os contextos de qualquer produção, atuação e/ou construção/descoberta e, sobretudo, respeitar o fazer do outro. Essa perspectiva, de sempre analisar o contexto, considero como forma de ver e agir no mundo, referente à minha formação pessoal, que trago como posicionamento para localização de onde falo.

Sempre gostei de estudar o lúdico e tudo que o envolve. Assim, defendi minha especialização na Faculdade de Educação da $\mathrm{UFG}^{9}$, investigando este tema nos conceitos de ensino/aprendizagem sócio interacionista. Unindo toda essa experiência, registrei a história do grupo Gwaya - Contadores de histórias/UFG - em meu mestrado ${ }^{10}$, caracterizando a contação de histórias como atividade de lazer, analisando suas consequências de encantamento ou aprisionamento para os ouvintes. Tema que pretendo retomar como um dos pressupostos para entender a elaboração do contador de histórias, de que trata esta tese, ampliando os conceitos de cultura e educação nela trabalhados.

Com uma vida cheia de surpresas e mudanças repentinas, fui transferida para a Escola de Música e Artes Cênicas (EMAC) da UFG, para ministrar aulas na licenciatura em Artes Cênicas, em 2002. A aproximação com o campo das artes cênicas revelou-me novas oportunidades e conhecimentos, obrigando-me a rever certos dogmas daquele primeiro grupo. Na continuação dos estudos, fui percebendo o quanto essa área contribuía para o contador de histórias, ao contrário do que se acreditava, anteriormente, no grupo que iniciei. Fui, aos poucos, reformulando posturas teórico/práticas, a fim de ampliar possibilidades para usos diferenciados dessa atividade artística, oferecendo contribuições que dialoguem com o campo das artes em geral.

Em 2006, comecei a lecionar uma disciplina de Núcleo Livre ${ }^{11}$, oferecida para os alunos de graduação de todos os cursos da UFG, intitulada: " $A$ arte de contar histórias", misturando alunos de áreas diversas, de forma bem interessante. Essa

\footnotetext{
9 Especialização na UFG, cuja monografia explorou a ludicidade, por meio da concepção de ensino/aprendizagem sócio interacionista de Vygotsky, Lúria, Leontiev e Wallon.

${ }^{10}$ Dissertação de mestrado defendida na Unicamp, em 2000, na FE, área de Estudos do Lazer, linha de pesquisa: Lazer \& educação. Publicado pela Cegraf/UFG, em 2005, com o título: Dos contadores de histórias e das histórias dos contadores. Atualmente com edição esgotada.

${ }^{11}$ As disciplinas de Núcleo Livre pertencem a um projeto da PROGRAD/UFG, desde 2004, do qual participam todas as unidades de ensino da UFG, e visam, entre outros objetivos, gerar saberes interdisciplinares e convivências entre os alunos de áreas diferentes, fazendo parte da última reforma curricular, atualmente em vigor.
} 
mistura provocava turmas questionadoras e ricas, porque diversificadas em experiências advindas de suas especificidades de atuação. Mas, sobretudo, me fez compreender a importância de considerar as potencialidades e limites de cada um, na aprendizagem do exercício da contação das histórias. É, especialmente, respeitando a forma e as escolhas de cada um, que os princípios dessa elaboração podem ser analisados e teorizados. Nesse sentido, não cabem respostas prontas, regras rígidas ou fixas, e sim, possibilidades a serem experimentadas e/ou recriadas, que constituem a sistematização da elucidação do contador de histórias na contemporaneidade, aqui teorizada.

O campo de pesquisa se constitui em minha vivência profissional de contadora de histórias e formadora de novos contadores, desde 1993, associada à outras conhecimentos de docência, num total de vinte anos como contadora de histórias e mais de trinta anos de sala de aula, na escola de ensino regular, em variadas atuações. Sendo uma experiência tão ampla, aponta para a necessidade de delimitação do campo a ser investigado, o que será exposto, oportunamente.

O problema formulado, em torno do objeto proposto, orienta possíveis caminhos e direções, na busca de respostas que incentivem novas investigações e muitas práticas de contadores de histórias. Como e porque pensar em uma formação de um contador de histórias na contemporaneidade, uma vez que sempre existiu um narrador oral? Quais princípios e fundamentos podem constituir a formação do contador, livre de modelos prontos? Quando e onde a atuação do contador de histórias pode contribuir com a formação de pessoas, com vistas a uma sociedade mais justa? Como investigar e aprofundar as técnicas do narrador oral, atendendo aos princípios levantados?

Contudo, é precisamente a experiência vivida, portanto real, que orienta e, ao mesmo tempo, justifica a hipótese de uma descoberta para o contador de histórias da atualidade. Não um modelo pronto a ser repetido, mas orientações que ampliem e deem subsídios à novas criações. Essa suposição me leva a investigar quais são os princípios e fundamentos teóricos para a elaboração de um contador, na contemporaneidade, inserido em sua dinâmica cultural, reconhecendo que essa prática se mantém em constante transformação, em razão das contradições e 
emoções presentes na História ${ }^{12}$ da humanidade, sendo este um recorte relativo à minha experiência.

O fato dos contadores de histórias existirem a muito tempo, ao longo da existência da humanidade, revela sua importância. As narrativas vêm sendo contadas, recontadas, recriadas, ouvidas, transformadas e registradas por meio de várias linguagens. Em minha observação, as histórias valorizam cada cultura em seu contexto, preservando biografias, inventando fábulas, ampliando imaginários. Ao mesmo tempo, faz de conta e vidas cotidianas se confundem e se fundem, num emaranhado de narrativas que vão revelando modos de viver e de ser; presentes, futuros e passados dos diferentes povos espalhados pelo planeta.

Contar histórias mobiliza o imaginário, permitindo vivência de tempos e lugares distintos. É uma viagem sem sair do lugar! As oportunidades criadas pelas narrativas podem ser infinitamente variadas, despertando emoções, ampliando conhecimentos, exercitando formas de interagir e oportunizar a prática da alteridade. Quando um ouvinte se identifica com determinado personagem de uma história e acaba por se colocar no lugar daquele papel, exercita sua alteridade, uma vez que pode entender o ponto de vista de outra pessoa, às vezes, contrário do seu, quase sempre diferente.

As narrativas mexem com a memória da humanidade, despertando e atualizando valores, educando cada povo com seus costumes e tradições. As histórias são, ao mesmo tempo, a reinvenção do que se quer mudar e a preservação do que se quer manter.

Assim, o objetivo desta investigação consiste em sistematizar uma experiência de descoberta/formação do contador de histórias na contemporaneidade, por meio da teorização de princípios e fundamentos que possam orientar e ampliar suas diversas práticas.

Decorrentes do objetivo maior serão considerados, ao longo da pesquisa, alguns outros desígnios que merecem um olhar mais atento, no sentido de contribuir com uma formação que amplie as possibilidades de atuação dos contadores. Reconhecer-se como contador de histórias, optando por desenvolver essa arte, faz parte do início da descoberta de um narrador oral, sendo fundamental ouvir muitas

\footnotetext{
${ }^{12}$ História aqui está grafada com letra maiúscula, por representar a área de conhecimento constituída pelos registros diversos das produções humanas.
} 
histórias. Saber escolher um texto e a linguagem própria a cada contexto implica ter liberdade em suas ações, assumindo a responsabilidade que lhe é devida.

As investigações seguem na direção da construção de referências para que cada um consiga estabelecer seus próprios critérios, para fazer suas próprias escolhas em relação as suas histórias, pensando em como preparar cada uma delas. A aplicação de técnicas no uso do corpo, por meio da voz, do gesto e do ritmo para o desenvolvimento da performance do contador de histórias, é uma das contribuições, por meio de minha experiência, no estudo de elementos da linguagem corporal, percebendo uma interferência na contação de histórias, exercitando-os por meio de jogos lúdicos. Espero, com isto, contribuir com uma educação que forme um ser humano mais feliz ${ }^{13}$, e, ao mesmo tempo, consciente de seu papel social e cultural.

A curiosidade, as necessidades profissionais, a vontade de melhorar sua prática, muitas vezes aliadas à falta de prática no ouvir e contar histórias, tem levado pessoas dos mais diversos níveis profissionais e sociais a procurar por uma formação na arte de contar histórias, como pode ser observado na demanda, com base na procura dos alunos por cursos e oficinas de formação do contador de histórias. Embora todos possam ser contadores de histórias, ao contrário do que parece, esta vivência, hoje, é pouco saboreada, por razões inerentes aos tempos modernos em que estamos inseridos, tema desenvolvido em meu mestrado, nas relações de tempo e Lazer. Desde que comecei a ministrar cursos de contadores, nunca mais parei, acumulando experiências interessantes e variadas. A proposta da presente sistematização nasce da vontade de dividir essas riquezas, compartilhadas com tanta gente diferente.

A delimitação dessa investigação, quanto às experiências de formação e quanto às apresentações de sessões de histórias, foi feita com a intenção de orientar a descoberta de cada narrador oral e foi demarcada pela minha vivência, como professora e contadora de histórias. O conhecimento é associado às análises que apontem as direções de um fazer livre e transformador, refletidas à luz de teorias e autores/contadores que corroboram com os fundamentos e princípios a serem explicitados. A escolha da base teórica da presente pesquisa é fundamentada basicamente em autores brasileiros, sobretudo contadores de histórias, e se justifica

\footnotetext{
${ }^{13}$ Felicidade aqui é considerada com base nas opções de cada um, não necessariamente igual para todos.
} 
por ser o objeto deste estudo enraizado em sua própria cultura. São referências que fazem parte da minha história, da minha identidade brasileira.

Desse modo, algumas questões se impõem, de imediato, em torno do objeto proposto, quais sejam, a construção de um contador de histórias que consiga suscitar no ouvinte a imagem e a emoção do conto. Quem é esse contador de histórias em construção? O aluno, o professor ou os dois? Precisa ser artista ou ator? Existem tipos diferentes de contadores? Quais seriam? O que envolve o imaginário presente nas histórias e, consequentemente, na ação do contar? Como se manifesta ou o que acontece com as emoções despertadas pelas histórias? Essas serão as primeiras aproximações com o tema. A escolha do repertório interfere no desenvolvimento do contador? Existe um repertório específico para cada idade? Como conhecer as histórias a serem contadas? Oralidade ou vocalidade? Como explorar a linguagem corporal na narração de uma história? Essas e algumas outras questões são desenvolvidas, ao longo da pesquisa, numa espécie de diálogo em torno da construção/formação do contador de histórias, nos dias atuais, com autores contadores que tem experiências semelhantes.

Para dar conta do problema formulado, as questões propostas exigem um método de abordagem que aceite posições abertas, mantenha os diálogos entre os conceitos e termos, permita transformações constantes, busque resultados qualitativos e ainda acolha as contradições inerentes aos seres humanos. A escolha do método dialético como abordagem para esta pesquisa se explica na aplicação dos quatro fundamentos apresentados pelas autoras (LAKATOS e MARCONI, 2003): "tudo se relaciona"; "tudo se transforma"; "qualidade no lugar da quantidade"; "interpenetração dos contrários”.

O primeiro fundamento, "tudo se relaciona", explicita a necessidade da superação das fragmentações de conceitos, definições e termos e, mostra que os recursos propostos nos estudos dos contadores de hoje são interligados, mantendo relações permanentes e mutáveis entre si, não tendo sentido entendê-los separadamente. Considero que as relações construídas pelo contador com seu corpo, com o espaço em que atua, com seu público e com o texto que está narrando são interdependentes, funcionando por meio de ações recíprocas e interrelacionadas. Se, às vezes, aparecem isolados é apenas por uma questão de aprofundamento dos termos e conceitos, para um melhor entendimento e consequente possibilidade de investigação e aplicação daquele recurso. Nas ações 
do contador, esses elementos aparecem como um único fenômeno. Essa interdependência se dá, também, entre os componentes dos conceitos que compõem esta pesquisa, construída segundo os preceitos de (DELEUZE e GUATTARI, 1992), sendo facilmente reconhecidos nas ações dos contadores de histórias. Para esses autores, todo conceito é formado com base em um ou mais problemas a serem resolvidos, é constituído por componentes que se interrelacionam e ainda possuem sua própria história.

O segundo fundamento é de que tudo se transforma e, nesse sentido, entendo que toda ação educativa é transformadora de si e do outro. Ninguém é igual depois de ouvir e/ou contar uma história, nada é definitivo e sagrado. Lidamos com fazeres e pensares maleáveis e transitórios, pois considero que a cultura é dinâmica. A interação alcançada com uma plateia pode não dar certo em outra, exigindo do contador atenção e capacidade de improviso. Cada um escolhe seu repertório movido por sua própria história, que vai sendo construída na medida em que é vivida, numa constante variação. O contador suscita em seu ouvinte a emoção e as imagens que o conto provoca, e isto, por si só, já é transformador, pois, além de permitir interpretações individuais, permite a construção de imagens, até mesmo de lugares nunca vistos antes. Mesmo quando recontada, uma narrativa continua propiciando transformações, ampliando a visão de mundo do contador e do ouvinte.

Qualidade no lugar da quantidade, na proposição das autoras (LAKATOS e MARCONI, 2003), é a terceira lei que se apresenta à abordagem dialética e que caracteriza, simultaneamente, o objeto deste estudo. Primeiro, por ser um objeto de arte cuja criação é única. Em um produto obtido somente pela repetição, a quantidade teria importância, mas, dificilmente, este é considerado um produto artístico, pois envolve outros parâmetros que pertencem mais ao sistema econômico vigente do que à produção artística. Nesse sentido, a quantidade não pertence à abordagem do método proposto, uma vez que sua discussão apenas denuncia a falta de políticas públicas para os setores de arte e de educação. A direção da formação que se quer construir, bem distante de modelos prontos, apresenta perspectivas de elaborações e escolhas que, por sua vez, envolvem estéticas e qualidades. São processos pessoais, mesmo quando conquistados coletivamente, artifícios desenvolvidos por cada contador, na busca por uma comunicação que envolva o ouvinte nas significações, emoções e imagens do conto narrado. 
O quarto e último fundamento da dialética, a interpenetração dos contrários, tem a presença da contradição como força e motor para as transformações dinâmicas e constantes. Assim, o método dialético é aquele que "penetra o mundo dos fenômenos através de sua ação recíproca, da contradição inerente ao fenômeno e da mudança dialética que ocorre na natureza e na sociedade". (LAKATOS e MARCONI, 2003, p. 106) Como exemplo, podemos citar os valores presentes nas histórias contadas, que acabam sendo assumidos pelos ouvintes, de uma forma ou de outra, merecendo cuidados e conhecimento do contador aprendiz, em razão das mudanças inerentes às sociedades. Nem sempre os valores de uma época são os mesmos de outros tempos e lugares, pois as experiências geram interrogações e, consequentemente, novas respostas, transformando as formas de entender e se colocar no mundo. A força dos valores de uma história parece se manter, ao mesmo tempo em que uma força contraditória, que provoca novas mudanças constantes e dinâmicas, aparece na modificação das histórias. Histórias que serviram para educar as sociedades ocidentais, por longos anos, ao ensinar o valor de "primeiro 0 trabalho, depois a brincadeira", como a conhecida fábula dos três porquinhos, são hoje questionadas por seus valores absolutos, fazendo surgir várias versões com base em um mesmo conto, como, por exemplo, "A verdadeira história dos três porquinhos", "O Lobo Guará e os três porquinhos caititus ${ }^{14 " . ~ H o j e, ~ a ~ d i s c u s s a ̃ o ~ m a i s ~}$ aprofundada, nessa área, vai mostrar que é possível e coerente brincar, mesmo durante períodos de trabalho, e que estes valores foram construídos com fins definidos e conscientes, para manutenção de um status-quo. A versão do lobo guará aborda discussões sociais e ecológicas que são investigadas e debatidas, hoje.

O contador de histórias, da atualidade, se apresenta como um acontecimento que vai além do cotidiano das comunidades, explorando habilidades artísticas e objetivos diversificados e específicos. Assim, o corpus teórico destacado para a comprovação desta tese é constituído por conceitos de diversas áreas do conhecimento, formando uma teoria, no sentido de que esta pode ser "considerada toda generalização relativa a fenômenos físicos e sociais, estabelecida com o rigor científico necessário para que possa servir de base segura à interpretação da realidade". (ibidem, 2003, p. 112) O rigor metodológico será perseguido nas análises

\footnotetext{
${ }^{14} \mathrm{O}$ primeiro título é de autoria de Jon Scieszka, ilustração de Lane Smith, editora Companhia das Letrinhas, 2005. O outro é: Os três porquinhos caititus e o lobo guará. Texto de Diane Valdez, ilustração de Francisco Veiga. Goiânia, editora Vieira, 2007.
} 
e reflexões iniciadas pelas indagações feitas, com base em observações empíricas das experiências vividas. Vivência, levantamento de questões e investigação dessas questões, nas diversas teorias que as envolvem, desenvolvendo uma reflexão teórico/prática, demonstram a ordem do rigor que se pretende manter na reflexão almejada, com base nas leituras dos autores e nas experiências de contadora e formadora, escolhidas como referência para esta pesquisa.

Para a constituição de um eixo epistemológico que atenda a abordagem do método dialético, a presente pesquisa se utiliza de conceitos nas áreas de: artes, antropologia, filosofia, história oral, educação, letras, psicologia e, mais especificamente, das artes cênicas. No entanto, para maior apoio teórico, fiz a opção de dialogar com as experiências dos próprios contadores que, por terem múltiplos olhares, podem me conduzir no foco da constituição/formação do contador, como orientação central.

A construção do contador de histórias em sua base teórica é constituída por contribuições de diversos autores, em áreas afins, levando-se em conta a multiplicidade do objeto em questão e as experiências empíricas advindas da prática de contar histórias e formar professores e outros profissionais, em várias áreas do conhecimento. Por essas razões, os autores que dão sustentação teórica a este estudo são, sobretudo, os contadores de histórias que investigaram e registraram suas experiências. Assumo, com isso, o risco de receber críticas por não ir direto à fonte, investigando a origem de conceitos que envolvem o tema. Entretanto, justifico essa escolha pelo foco da investigação estar direcionado à formação de um narrador oral, cujo eixo de interesse se faz no diálogo com outros contadores, nas análises e reflexões de suas práticas, relacionadas às experiências minhas e deles.

Resguardando a flexibilidade dos conceitos e as fronteiras permeáveis entre as definições e áreas de atuação, além das possibilidades técnicas que envolvem diferentes linguagens no contar uma história, a presente proposta não fecha uma única forma, e sim, apresenta caminhos a serem compartilhados por aqueles que escolhem aperfeiçoar sua prática artística. Nestas escolhas não há certo ou errado, mas maneiras diferentes para atender às realidades diversas.

Os procedimentos e técnicas metodológicas, assim como a delimitação do campo de análise empregadas na investigação foram pensados e organizados com base no material disponível, acumulado nos vinte anos de experiência. 
Como descrição desse material, assinalo: as fichas de planejamento de oficinas e minicursos, que continham anotações, geralmente, do funcionamento ou não das dinâmicas trabalhadas nas oficinas. Essas oficinas foram ministradas, em sua maioria, para professores de ensino básico da rede pública do ensino, no Estado de Goiás - também em outros Estados brasileiros e, não somente atendendo ao público de professores, sendo encontrada uma diversidade inumerável de pessoas, áreas e intenções diferentes, na participação das oficinas.

Os cadernos de planejamento de curso maiores, onde também eram feitos os diários de campo, com comentários sobre as aulas, dos cursos com maior duração (64h). Selecionei apenas a experiência com o Núcleo Livre, disciplina oferecida, dentro do currículo da UFG, a todos os alunos, de todos os cursos. Foram selecionadas quatro turmas, entre 2008 e 2011, e o material inclui uma auto avaliação dos alunos, cujas respostas foram de extrema importância para o início de uma possível organização da estrutura da tese. Um questionário semiestruturado e aberto, admitindo respostas com base nas experiências de cada um, contendo informações subjetivas e objetivas que coadunam com as bases teóricas da presente reflexão. No momento em que seus dados forem acessados, ao longo da escrita da Tese, a descrição exata de sua utilização se fará acompanhar. Foram selecionadas cinco turmas, num total de 85 questionários que foram utilizados em vários momentos da pesquisa, sobretudo, no quinto capítulo.

As sessões de histórias que ficaram marcadas, por alguma razão, e que foram ressurgindo em minha memória ao encontrar ressonância na escuta de outras experiências, ou nas reflexões de minha própria ação, também aparecem como material de análise proveniente da experiência investigada. Nessas lembranças de contação de histórias estão muitas vivências das relações de interação com o público, sobretudo, nos improvisos, que por serem inusitados e espontâneos, nos fornecem reflexões importantes acerca das técnicas de narração.

Entre sessões de histórias e oficinas, reservo como uma das maiores preciosidades, os eventos específicos de contadores de histórias e afins, como feiras literárias; Cantinho da leitura ${ }^{15}$, Boca do Céu ${ }^{16}$ e outros. As participações como

\footnotetext{
${ }^{15}$ Evento de literatura infantil e juvenil que equipou todas as salas de aulas de ensino fundamental das escolas estaduais, em 2002; projeto que sem dúvida representa um marco no incentivo à leitura no Estado, embora tenha sido suspenso, pelas gestões políticas subsequentes.

16 Evento bianual de contadores de histórias, promovido pela contadora e professora Regina Machado, da ECA/USP, e São Paulo.
} 
contadora, oficineira ou simples participante me ajudaram a construir uma visão além de minha própria experiência, ampliando conhecimento e possibilidades, bem como me oportunizaram o acesso à maioria dos autores que trabalho.

O exercício constante da aproximação e distanciamento do objeto investigado, necessário ao rigor científico da pesquisa, foi conduzido com sabedoria por minha orientadora, que sempre alerta às minhas generalizações, me empurrava a uma desestrutura necessária à reflexão, que significa um repensar a prática, agora, com apoio de uma teoria, para chegar às possíveis contribuições para a construção do contador de histórias. Assim, organizei, desorganizei e reorganizei todo o material subdividindo-o em capítulos, itens e subitens, por mais de três vezes, tentando perceber a importância de entender com o olhar do outro, para conseguir contribuir.

Portanto, a organização metodológica foi sendo construída ao longo do percurso, na medida em que os problemas surgiam e precisavam de uma solução. Ao privilegiar o diálogo com os outros contadores, sinto minha prática enriquecida no encontro dos caminhos percorridos e de novos caminhos a serem descobertos.

A fim de organizar e sistematizar a construção/formação do contador de histórias na contemporaneidade, por meio de minhas experiências pessoais, ofereço caminhos, em lugar de receitas prontas, nos cinco capítulos, a seguir, apresentando o contador de histórias em seu contexto e sua constituição, por meio da sistematização de uma experiência pessoal dialogada com outras experiências que possam abrir espaços para cada contador de histórias se descobrir com liberdade e conhecimento.

A primeira discussão apresentada tem por base o delineamento do contexto em que se insere o objeto de pesquisa, em seu universo geral e particular, considerando a importância dessa compreensão, para entender as possibilidades de descoberta da construção/formação do contador de histórias na contemporaneidade, capaz de assumir suas próprias escolhas e atitudes. Aproveitando parte dos estudos do mestrado, aprofundo as discussões sobre cultura e educação e arte, tecendo a rede de conceitos que insere o narrador oral na contemporaneidade, em busca de princípios e fundamentos que the apontem caminhos para a sua elaboração. Ao eleger o espaço da escola como parte da delimitação do campo de pesquisa, priorizo minha experiência pessoal, por acreditar ser esta minha maior contribuição. Avaliando a importância não só do diálogo entre escola e comunidade, como 
também, considerando que a elucidação do contador, aqui proposta, não quer apontar espaços restritos de atuação, pelo contrário, deseja ampliar possibilidades. Por isso, trago também, na reflexão, algumas experiências fora da escola.

O segundo capítulo intitula-se "O sujeito contador de histórias". Revela o protagonista de nossa pesquisa, o objeto central, alvo das investigações propostas, o contador de histórias na contemporaneidade. Identifica vários tipos de contadores de histórias coexistindo com saberes e papeis diferentes. Recorte complicado por não eleger um tipo de contador para investigar. O contador de histórias, sujeito dessa pesquisa, se faz na multiplicidade de possibilidades para construção de um narrador oral, na contemporaneidade. A delimitação do sujeito é constituída pelo contador de histórias que procura deliberadamente por uma formação, um contador que também assume a responsabilidade dos saberes que envolvem essa arte.

No terceiro capítulo, procuro o que torna o contador de histórias presente. Não a presença de palco estudada no teatro, mas aquilo que faz o contador de histórias existir, em sua arte. Na concepção de Ana Mae Barbosa ${ }^{17}$, uma obra de arte se completa na leitura do espectador, fazendo-me crer que a arte de narrar, de se fazer presente está no 'contar com': momento de comunhão do conto, em que contador e ouvinte dão significado às palavras ditas, característica que pertence a todos os tipos de contadores de histórias, indistintamente. Assim, investigo: como a memória é envolvida e envolve o contador de histórias; de que maneira o contador de histórias suscita em seu ouvinte a imagem e a emoção do conto que está narrando; como entender a memória e a reminiscência ligadas à ancestralidade do narrador oral; como aprender com a espontaneidade. Desse modo, a compreensão sobre memória, emoção, imaginário e espontaneidade em suas relações com o contar histórias são percebidas como fatores preponderantes na constituição da presença do contador de histórias, que 'conta com', seu ouvinte.

No quarto capítulo é oferecida uma variedade de possibilidades para a constituição do repertório de um contador de histórias, na contemporaneidade, com o fundamento de que a escolha e a percepção crítica se constroem com o conhecimento, por meio de critérios pessoais e coletivos. Os campos teóricos que orientam e apoiam essa discussão são os conceitos de narrativa, oralidade e sócio linguística, na intenção de perceber o que envolve a preparação do conto, antes de

\footnotetext{
${ }^{17}$ Arte educadora de referência no Brasil, autora da Abordagem Triangular para o Ensino de Artes.
} 
refletir sobre as técnicas corporais envolvidas em sua preparação e contação. Este é o desafio que se impõe ao manter a proposta aberta, respeitando as especificidades do texto e do contador, assim como, respeitando o público ouvinte e a própria atividade.

No quinto capítulo, investigo como são construídas as técnicas da linguagem corporal que podem interferir na eficiência da narração de uma história. O fundamento dessa busca é o autoconhecimento corporal, no sentido de explorar os recursos e potencialidades de cada corpo que se dispõe ao diálogo com o outro. Com o pensamento de que somos nosso corpo, e não, temos um corpo, procuro recursos corporais, desenvolvidos por meio de jogos e brincadeiras em minhas oficinas e cursos, com base em um quadro de recursos (em anexo 1) utilizados, por muitos anos. A teorização e consequente reflexão dos elementos desse quadro passaram por alterações, tanto em seus conceitos, como em sua estrutura. Organizei este capítulo com os diálogos entre minhas experiências e autores que são, também, contadores de histórias e registraram suas práticas, na intenção de que a riqueza dessas práticas possa servir de estímulo para antigos e novos contadores.

Assim, a subdivisão apresentada segue a orientação de não ser considerada em sua fragmentação, e sim, na necessidade da verticalização do conhecimento. A cada um dos subitens: oralidade, gestualidade e ritmo, seguem-se outros que deles derivam, mas quando entram em ação é o corpo todo que participa, por inteiro. Cada elemento age individual e coletivamente, por meio da linguagem do corpo, na intenção de dar significado ao conto que está sendo narrado.

Ao analisar os recursos da linguagem corporal que participam da narração de uma história concluo que a formação/construção de um narrador oral inclui o domínio desses elementos, entretanto, vale advertir que não são todos utilizados em um mesmo conto, ou pelos mesmos contadores, ou, ainda, necessários de serem obrigatoriamente desenvolvidos. A perspectiva colocada de uma educação para a autonomia exige que cada um conheça e amplie seus conhecimentos, de acordo com seus próprios princípios de vida em sociedade. 


\section{CAPÍTULO 1 - 0 CONTEXTO DA PESQUISA - CULTURA, EDUCAÇÃO E ARTE: uma rede conceitual que envolve o contador de histórias.}

Caminhante, não faço o caminho por onde eu caminho, mas o caminho me faz o seu caminho. Carlos Brandão

Ao investigar e identificar o objeto de estudos proposto para a presente tese, procuro, nessas páginas iniciais, revelar o contexto em que se insere o contador de histórias na contemporaneidade. A rede conceitual tecida pela trama que envolve o narrador oral em seus estudos se constrói em torno das definições de cultura, educação e arte, por ser este o contexto escolhido para o recorte e aprofundamento do tema apresentado, uma vez que a presente pesquisa tem por base experiências consolidadas na área da educação. Considerando este contexto, apenas como uma das possibilidades para a atuação dos contadores de histórias na contemporaneidade, sem desmerecer tantos outros existentes, utilizo-o para analisar e refletir conhecimentos que considero esclarecedores na aprendizagem da arte de narrar.

Ao identificar o contador de histórias inserido no mundo atual, em suas funções sociais, educativas e artísticas, portanto, culturais, percebo a quantidade de termos e conceitos que emergem do tema, envolvendo aspectos que, embora se apresentem, muitas vezes, de forma isolada, são aspectos e categorias interdependentes e/ou interligadas. Considero que cultura, arte e educação pertencem ao universo do ser humano, que tecendo uma rede de significados e conceitos, que não são fixos, podem enriquecer o entendimento da construção do contador de histórias na contemporaneidade. Portanto, estudos sobre cultura, educação e arte contribuem na construção do contexto e da perspectiva em que se insere o contador de histórias da presente pesquisa, embora esse sujeito seja tematizado/problematizado somente no capítulo seguinte.

Para entender meu ponto de partida, ou sob quais perspectivas e concepções meu objeto de estudo se apresenta, recorro aos estudos que sustentaram minha 
prática docente e que apoiaram minha experiência, aqui refletida. A fim de identificar o contexto atual do contador de histórias, proponho um aprofundamento nas discussões em torno do entendimento da cultura, da arte, da educação, seja ela dentro ou fora da escola, para compreender os princípios e fundamentos que apoiam a construção do contador de histórias, dessa pesquisa.

Meu desafio como contadora de histórias se dá na direção de uma educação para a autonomia, onde o aluno se sinta sujeito de sua própria aprendizagem, sendo capaz de interferir na realidade, transformando-a em direção à construção de uma sociedade mais justa e mais feliz. E por que não, mais democrática.

A intenção não indica conceber uma posição hermética, muito menos um modelo de ensino, pelo contrário, objetiva ampliar os entendimentos e condições críticas das quais um narrador oral carece em sua descoberta, considerando a autonomia e variedade de objetivos possíveis em sua constituição, na atualidade. Portanto, é no reconhecimento de seu próprio contexto, que cada narrador oral escolhe seus objetivos e ações, observando outros contadores, abrindo diálogos, enriquecendo suas práticas.

Em meus estudos de mestrado, as definições de cultura e educação são exploradas, no entendimento do contador de histórias, como atividade de lazer, mostrando suas possibilidades de encant(o)ar (leia-se: encantar ou encantoar). Ou seja, o contador de histórias pode tanto encantar, no sentido de libertar o ouvinte, deixando-o livre para sentir/entender/interpretar a história, à sua maneira, ou, por outro lado, pode encantoar, no sentido de aprisioná-lo, exigindo, por exemplo, um entendimento único advindo da visão do contador, de acordo com seu entendimento do mundo. Esta segunda forma é ainda encontrada em muitas escolas brasileiras, que permanecem com um ensino tradicional, marcado pela velha cópia de conteúdo do "quadro negro, ou lousa", distantes da realidade ou do interesse do aluno, revelando a desigualdade entre as escolas e a falta de uma formação continuada ${ }^{18}$, na educação brasileira. Desta forma, um dos fundamentos que orienta a construção de um contador de histórias, na perspectiva da educação, aqui colocada, seja ela

\footnotetext{
${ }^{18}$ Considerada aqui em relação às necessidades constantes de uma continuidade dos estudos dos professores, após a conclusão da graduação, ou seja, formação durante o tempo de trabalho, em razão das constantes transformações humanas. Infelizmente as políticas públicas para a educação não têm garantido essa necessidade, pois na desvalorização da remuneração dos professores, estes são obrigados a trabalhar em mais de uma escola, ou, às vezes, em até três turnos, para cumprir obrigações familiares, deixando de participar das possíveis reuniões de discussões e planejamentos, que deveriam ser cotidianas nas escolas.
} 
dentro ou fora da escola, é a necessária reflexão permanente sobre as consequências de suas atitudes em suas escolhas, tanto do repertório, como no uso da linguagem corporal, temas desenvolvidos nos capítulos 4 e 5, dessa pesquisa, respectivamente.

Por meio dos estudos de Huizinga (1971), entendo que a ludicidade faz parte do ser humano, enquanto característica inerente a ele, independente de sua cultura, pois que o brincar é anterior à cultura humana. Por isto, defendo uma educação escolar em que o espaço para a vivência da manifestação lúdica ${ }^{19}$ seja garantido. Portanto, outro fundamento na aprendizagem do contador de histórias, presente todo o tempo em minha prática docente é: "aprender brincando", tema e ação que me acompanham nas experiências com a educação escolar, e que me aproximou dos estudos dos jogos teatrais.

No mestrado, além dos estudos da ludicidade humana, a contação de histórias foi caracterizada como atividade de lazer, analisada na contemporaneidade, considerando as fragmentações presentes nos fatos culturais da época atual. Os estudos antropológicos de Geertz (1989) e Brandão (1985)(1995), e filosóficos de Laterza e Rios (1971) e Henrique Lima Vaz (1966), indicaram as dimensões diferentes da cultura, na vida dos seres humanos, ao longo de sua existência, se fazem em razão de suas condições, necessidades e capacidades. Disso se depreende a dinâmica da cultura, observada nas constantes transformações humanas. Segundo Vaz (1966), uma obra cultural, representada por sua face objetiva, só pode ser compreendida por meio do sentido conferido pelo ser humano, como sujeito do seu processo cultural. Essa atribuição/compreensão de sentido, ou seja, essa significação da obra, de acordo com o autor, constitui a parte subjetiva da cultura, pois as obras humanas "atestam ao homem a essência e o sentido de sua presença no mundo: a presença de um sujeito que compreende, transforma e significa" (VAZ, 1966, p. 5). As sociedades mais industrializadas, pertencentes ao sistema capitalista da contemporaneidade, costumam se preocupar com quantidades produzidas em detrimento daquilo que faz sua qualidade, ou seja, do processo de sua construção, caracterizando a atual alienação cultural ${ }^{20}$.

\footnotetext{
${ }^{19}$ Os autores nos quais me apoiei nos estudos do lazer e do lúdico foram: (DUMAZEDIER 1986); (HUIZINGA 1971); (LAFARGUE 1990); (MARCELLINO, Lazer \& Educação 1987), (MARCELLINO, Pedagogia da animação 1991), (MARCELLINO, Estudos do Lazer: Uma nova introdução 1996).

20 Temas trabalhados em minha dissertação de mestrado - Unicamp (FEF - 2000).
} 
Para Geertz (1989), a importância da cultura está em sua interpretação, na análise de seus vários significados, da origem e das possibilidades de ressignificação do fazer humano. Ao propor uma teoria interpretativa das culturas, o autor recusa a posição funcionalista e defende a necessidade de considerar o dinamismo cultural, partindo do referencial da semiótica e assumindo a perspectiva da interpretação e da ressignificação contínua.

No conjunto das grandes transformações sociais ocorridas na Europa, em fins do século XVIII, ou princípio do século XIX, se evidenciam as fragmentações que se polarizam em torno de dicotomizações ou polarizações, como: rural/urbano; oral/escrito; tradicional/moderno; erudito/popular; racionalidade/afetividade; teorização/vivência; religioso/mágico; civilizado/primitivo; racional/irracional; histórico/mítico; e outras. Como posicionar os contadores de histórias frente a essas polaridades, sem perpetuá-las, ou reforçá-las? Como analisar o contador de histórias na contemporaneidade, uma vez que ele aparece nos lados opostos, por vezes, de forma simultânea? Assumo o contador de histórias como alguém que perpetua e dinamiza sua cultura, independente do grupo ao qual pertence e que tem, de certa forma, o poder de vencer essas polaridades.

Como consequência das mudanças no processo civilizatório ocorrido na Europa, a partir do século XVIII, alguns intelectuais reconhecem "um sistema cultural de preservação do "espírito do povo" (ROCHA 2007, p. 2), dirigindo as investigações para as manifestações das classes menos favorecidas. Mais adiante, em 1848, o inglês Willian John Thomas assumiria o termo folk-lore para diferenciar e identificar os saberes tradicionais do povo. Carlos Brandão (1982), ao investigar os significados do uso do termo, quase dois séculos mais tarde, apresenta duas acepções: "Na cabeça de alguns, folclore é tudo que o homem do povo faz e responde como tradição. $\mathrm{Na}$ de outros, é só uma pequena parte das tradições populares" (BRANDÃO, 1982, p. 23). Continuando a descrição das duas acepções, o autor mostra, claramente, que a diferença está em alguns teóricos considerarem folclore e cultura popular como sinônimos e outros aceitarem apenas uma pequena parte das tradições populares como folclore.

O termo cultura continua chamando a atenção de muitos pesquisadores, pela variedade de maneiras e atitudes observadas, e, ao mesmo tempo, pela importância que assume nas consequências desses usos e significados. Não se trata de defender ou escolher uma posição, ou considerar uma melhor que a outra. É 
justamente o oposto. O maior valor está em evitar comparações avessas, compreendendo e aceitando as diferenças de cada indivíduo ou coletividade, em cada contexto, tendo que, para isso, procurar aceitar posições teóricas que acolhem posições abertas e diversas, com base em pontos de vistas diferentes. Trata-se, então, de conhecer para reconhecer; um grande desafio!

A variedade de entendimentos relacionados ao termo cultura, tanto na academia, quanto fora dela, tornam complicadas não só a tarefa de conceituá-la, mas, também causam mal-entendidos em certas situações do cotidiano. Em minha área de atuação, qual seja, das artes, a confusão é constante, muitas vezes, gerando preconceitos, poucas vezes percebidos.

Convidada a ministrar um curso de "arte-educação", em Porangatu ${ }^{21}$, para professores de arte da rede pública, como atividade de uma Mostra de Teatro ${ }^{22}$, organizado pela agência de cultura do Estado de Goiás ${ }^{23}$, qual não foi a minha surpresa, ouvindo os comentários das alunas/professoras sobre a presença de Chico Anísio, na cidade, declarando ao jornal local que "se orgulhavam de poder trazer cultura para um lugar tão distante e esquecido, que não tinha cultura". Perante os elogios e aceitações da fala do artista, percebi, claramente, que, até aquele momento, para aqueles professores cultura era o que vinha da secretaria de cultura, ou da televisão e se resumia a produtos artísticos que vinham, sobretudo, de grandes centros urbanos. Minha opção, após ouvir das alunas o que era por elas considerado como cultura local, regional, nacional e mundial ${ }^{24}$, foi apresentar contextos envolvidos nos exemplos deles, assinalando como mudavam as

\footnotetext{
${ }^{21}$ Cidade do interior do Estado de Goiás, localizada ao norte do Estado, mais próxima ao Estado de Tocantins, considerado polo agropecuário dos mais ricos da região. É passagem obrigatória de quem vai para o norte do país, muito usada para pouso dos viajantes.

${ }^{22}$ TeNpo - Mostra de Teatro Nacional de Porangatú, uma parceria (Agepel - Agência Goiana de Cultura Pedro Ludovico Teixeira e Prefeitura Municipal Porangatu. Surgiu em 2001, como ação estratégica pela localização que atrai todo o norte e nordeste do estado, oferecendo shows, peças teatrais e oficinas com artistas nacionais, regionais e locais. Em 2014, foi realizada a $14^{a}$ edição da Mostra, que já passou por altos e baixos, mas se manteve, como prova de seu valor e importância para a cidade e entorno.

${ }^{23} \mathrm{Na}$ época AGEPEL - Agência de cultura do Estado de Goiás, órgão que ocupou o lugar da extinta Secretaria de Cultura do Estado de Goiás. Em 2015, o governador reeleito, em nome do "enxugamento da máquina pública" extinguiu três secretarias, para recriar a antiga Secretaria de Cultura, Educação, Esporte e Lazer. Infelizmente isso não significa unir os aspectos humanos que se apresentam de forma fragmentada na atualidade, e sim, representa menores verbas para as ações necessárias à construção de um país democrático, na medida em que não atende as necessidades básicas da população.

${ }^{24}$ Essa é uma das indicações dos Parâmetros curriculares Nacionais (PCN) de arte, em que o professor identifica, com seus alunos, a cultura local e regional, ampliando o conhecimento com exemplos de outros locais diferentes.
} 
interpretações, dependendo do ponto de referência colocado, até que conseguissem acolher o valor da cultura local, se reconhecendo como produtores de sua própria cultura, valorizando-a. Ou seja, em outras palavras, procurei fazer um trabalho de recuperação da identidade daquelas professoras, que, provavelmente, tiveram pouca ou nenhuma chance de serem ouvidas, contrariando os ensinamentos de nosso grande educador Paulo Freire, orientação constante em minha prática docente.

O aprofundamento das questões debatidas gerou uma riqueza de respostas, ultrapassando a discussão de sala de aula, pois além das reflexões, ações se concretizaram, produzindo resultados surpreendentes, como: o início da construção de um projeto para o ensino de artes na cidade, envolvendo as redes públicas e privadas, considerando as riquezas da região; criação de um grupo de contadores de histórias, ${ }^{25}$ para dar suporte às professoras nas escolas; apresentação artística dos resultados da oficina, expondo a variedade e riqueza da cultura local (contação de histórias em várias linguagens, recuperando a história da cidade; a culinária servida no refeitório para os envolvidos no evento; apresentação ao público do planejamento do ensino de artes nas escolas). A reflexão dessa turma demonstrou sua compreensão, em ações de transformação no cotidiano das escolas, pelo menos nas aulas de artes, o que pode ser verificado, em anos posteriores, ao mesmo tempo que confirmou a necessidade do reconhecimento e valorização da cultura dos sujeitos envolvidos em qualquer ato ou processo educativo.

O mais importante, no meu entendimento, é que os professores parecem ter compreendido que não se leva ou se transporta cultura para os lugares, pois cultura é resultado dos significados de ações humanas. Todo fazer humano que contém um significado é cultural, pois "cultura é humanização" (LATERZA e RIOS, 1971, p. 56). É a maneira como o ser humano modifica a natureza a seu favor. Dessa forma, não existe ser humano desprovido de cultura. A discussão e a vivência dessa experiência encontra eco nas ideias de Roberto Da Matta (1981), mais especificamente, em seu texto: "Você tem cultura?", em situações comparáveis. Da mesma forma, como na resposta dos índios, na carta ao presidente dos Estados Unidos (BRANDÃO, 1995), os arte-educadores de Porangatu escreveram bilhetes de respostas, que foram reunidas e reorganizadas em exercícios lúdicos, na oficina,

\footnotetext{
${ }^{25} \mathrm{O}$ grupo foi criado, sobrevivendo apenas no ano de 2008.
} 
finalizando com um bilhete de toda a turma: "És bem vindo em nossa cidade, Sr. Artista, assim como todos os artistas! Mas, não para preencher um vazio, e sim, para ampliar nosso universo cultural, com sua arte! Oferecemos em troca, conhecimentos de nossa cultura!"

A existência de um Ministério da Cultura ou das Secretarias de Cultura, com a responsabilidade do fomento às artes, ainda que na tentativa de respeitar diversidades, origem, linguagens e modalidades, e até mesmo, considerando "tipos" de cultura (popular, erudita, de elite, de massa, etc.), revela a inconformidade do nome, pelas confusões de entendimento, sendo comum a intenção de "levar cultura", geralmente, aos menos favorecidos, deixando de reconhecer o próprio universo cultural pertencente a cada povo e a cada contexto. As diferentes realidades deste imenso país mostram a riqueza de sua pluralidade cultural, ao mesmo tempo em que as políticas públicas seguem outras direções, nem sempre conseguindo a valorização de forma a respeitar essa heterogeneidade, ou, por outro lado, nem sempre conseguindo valorizar as manifestações das classes menos favorecidas. Embora reconheça avanços nesse sentido, a partir da reorganização do Ministério da Cultura, realizada por Gilberto $\mathrm{Gil}^{26}$, com o reconhecimento e empoderamento de saberes populares, tais políticas ainda não conseguiram vencer tantos anos de exclusão. São muitos os fatores que interferem nessa dinâmica. Para a educação, fica a difícil tarefa de reconhecer que em cada lugar a cultura tem suas particularidades e permite interpretações plurais, aos múltiplos sujeitos, sem escala de valores, aceitando e reconhecendo que as trocas e/ou influências interculturais podem ampliar as possibilidades de aprendizagem e participação no mundo, entre as pessoas.

Concordo com Geertz quando diz que: "Cultura é um todo complexo incluindo conhecimentos, crenças, arte, moral, leis, costumes, ou qualquer outra capacidade ou hábitos adquiridos pelo homem como membro de uma sociedade" (1989, p. 79). Não como imposição, força externa ou hereditariedade, mas como parte das próprias capacidades humanas. A cultura é dinâmica porque é recriada pelo ser humano em todos os significados que este atribui às suas próprias ações. "Cada cultura segue seus próprios caminhos em função dos diferentes eventos históricos

\footnotetext{
${ }^{26}$ Como referência, posso citar o programa "Cultura Viva", do Minc, em 2004, cujo apoio financeiro, em todo o Brasil, tentou alcançar grupos e instituições já existentes, conseguindo atingir classes menos favorecidas, reconhecendo e valorizando formas populares de manifestação.
} 
que enfrentou" (LARAIA, 2004, p. 36/37). Entendo que os dois autores conseguem mostrar a superação de uma ideia central, vista como única ou dominante, levando à aceitação do dinamismo e das diferenças culturais, levando a um reconhecimento da importância de estudos nessa direção, que reconheçam o valor de cada sociedade e/ou comunidade, sem comparações hierárquicas entre si.

Reconheço que, nos tempos atuais, existe certa abertura, reconhecimento e procura na academia pelos saberes populares e na luta por sua legitimação, ainda que de forma insuficiente, para a superação da ideia da forma popular, como saber de menor importância. A história da educação brasileira mostra que, ao deixar de valorizar as formas de arte e cultura ligadas às classes populares ou ao povo, acaba por repercutir o entendimento de que são formas menores de cultura, influenciadas por uma corrente de pensamento cuja origem europeia dominou todo o ocidente, por muito tempo. As mudanças provocadas pelo surgimento da Antropologia, como área de saber, a partir do final do século XVIII, alteram, fundamentalmente, a noção de cultura desvinculando-a de valores progressivos que a colocavam como sinônimo de uma educação formal, erudição ou civilidade (TIBAJI, 2010). Se antes a cultura se comparava ao status de "civilidade" de determinado povo ou comunidade, comparados à civilização ocidental europeia, vai, aos poucos, sendo acolhida de forma a considerar as especificidades de cada contexto, ou seja, tudo que envolve os significados daquele povo, naquele lugar.

Os contadores de histórias cumprem, ao mesmo tempo, uma função social e cultural. Social pelo poder de agregar pessoas, por ser uma atividade coletiva, que exige, no mínimo, um contador e um ouvinte, e cultural, pelos significados que cada conto suscita e envolve.

Não se trata de entender o contexto com uma configuração estática, quando o contorno aponta uma dinamicidade constante. É preciso perceber que as várias denominações em torno da cultura são construídas historicamente para atender às necessidades de épocas e locais distintos. O entendimento dessa variedade pode desmanchar preconceitos e ampliar futuras escolhas, daqueles que se constroem como contadores, no século XXI.

$\mathrm{Na}$ atualidade, os estudos da cultura popular revelam um campo com múltiplas abordagens e disputas. Ao estudar as relações que o teatro popular estabelece com as culturas tradicionais, Rabetti (2000) se apoia em José Jorge de Carvalho, que coloca a cultura popular entre as culturas tradicionais e as culturas de 
massa (fruto da indústria cultural). Para a autora, a cultura popular, hoje, se identifica com o conjunto de produções e manifestações que, inseridas na produção de massa, preservam as dimensões, ou aspectos de valores e características das culturas tradicionais (RABETTI, 2000)

Em uma abordagem "histórico-estrutural" na investigação da constituição do conceito de cultura popular, no Brasil, Gilmar Rocha (2007) realiza um rico exercício de reflexividade epistemológica, examinando e identificando três fases no estudo do mesmo objeto: a sociologia do folclore (nos anos 20), a ideologia política da cultura popular (nos anos 60) e a antropologia do patrimônio (nos anos 90).

Segundo ele, nos anos vinte, os estudos folclóricos são alvos de reflexão de alguns intelectuais e artistas, que viram nas manifestações culturais das camadas menos favorecidas uma fonte de inspiração para sua obra, a exemplo de Mario de Andrade e Villa Lobos. A maneira pela qual os estudos do folclore foram desenvolvidos, se conectando aos elementos da tradição, suscita descontentamento naqueles que entendem a cultura popular como transformação.

$\mathrm{Na}$ contribuição para o debate entre folclore e cultura popular, Carlos Brandão entende que os produtos da cultura são "coisas da natureza transformados pelo trabalho do homem sobre ela e significados através do trabalho que o homem faz sobre si mesmo" (1982, p. 32/33). Denotando não haver polaridade entre folclore e cultura popular, ainda que seu significado possa ser heterogêneo.

A partir da década de sessenta, a cultura popular ganha um sentido ideológico, ficando atrelada à consciência política, como coloca Rocha:

(...) o elemento que parece sustentar a distinção entre folclore e cultura popular consiste no desenvolvimento da sociedade urbana, culturalmente marcada por visões de mundo e estilos de vidas modernos. Neste momento, sem perder de vista a convivência de manifestações folclóricas e da indústria cultural no espaço urbano, o conceito de cultura popular será profundamente marcado pelas experiências artísticas e percepções políticas desenvolvidas na cidade; é o que observam, por exemplo, Magnani (1982) e Carvalho (1992) (ROCHA 2007, p. 7).

Os Centros Populares de Cultura assumem uma função pedagógica, ficando atrelados aos movimentos de educação libertadora da época, vinculadas às ideias de Paulo Freire e do Movimento de Educação de Base, da igreja católica. O conjunto de transformações da época em que o próprio conceito geral de cultura se amplia, 
mostra a necessidade de superação das diferenças culturais, vistas em escalas de inferioridade entre quaisquer grupos sociais.

A opção pelo termo "patrimônio imaterial", por volta dos anos 90, faz parte das tentativas de superação de fragmentações, como a suposta incomunicabilidade entre as culturas popular e erudita. "A aproximação recente da Antropologia com o folclore encontra no patrimônio, mais uma vez, um meio termo para expressar em outras bases a cultura popular" (ROCHA, 2007, 16). Com as fronteiras relativizadas, embora não superadas, a indústria cultural vem fornecendo ingredientes para o aumento da complexidade do tema.

Joana Abreu (2010) alerta para o fato de que é a própria elite quem classifica como cultura popular, visão que nem sempre é compartilhada pelos múltiplos significados de popular: feito pelo povo, feito para o povo, pertencente a classes sociais menos favorecidas, ou ainda, oposto ao erudito, ao que é nobre e válido socialmente.

Antônio Nóbrega, em recente entrevista ${ }^{27}$, assumiu, claramente, não acreditar na oposição entre cultura popular e cultura erudita. Esse tipo de pensamento pertence àqueles que aceitam o dinamismo da cultura e as diferenças entre as pessoas, como consequências de seus fazeres e suas histórias, alterando o sentido das oposições, ou polarizações entre as culturas. Para o multiartista, somos herdeiros de um patrimônio da cultura ocidental, da Europa, chamada de cultura erudita. "Por outro lado, foi se formando no Brasil uma cultura marginal, periférica, de extração popular, tributário de outros universos culturais, por exemplo, dos negros e dos índios" (NÓBREGA, 2015). Somos herdeiros de tudo isso e ainda contribuímos com as transformações provocadas pelas interações entre culturas que conhecemos.

$\mathrm{Na}$ atualidade, há que se considerar que toda essa riqueza de material simbólico advinda do universo popular traz formas mais lúdicas e sensoriais, tem servido de referência para aqueles que buscam um simbolismo contemporâneo, a exemplo das multiartes, ou aquelas que se situam entre as fronteiras, misturando linguagens e recriando formas.

Acredito que o contador de histórias pertence ao universo humano, indistintamente. Visto assim, pode ser percebido, simultaneamente, pelas duas

\footnotetext{
${ }^{27}$ Programa de entrevistas: Roda Viva da TV Cultura. Acessado em janeiro de 2015.
} 
formas de cultura (erudita e popular), porque são carentes uma da outra, pois convivem em espaços e tempos coincidentes.

O historiador Hilário Franco (1996) explica que a cultura ocidental é marcada pela história do cristianismo, que por sua vez, construiu parte de seus ritos com influência de rituais profanos, pertencentes às camadas populares, comprovando a inexistência da oposição entre erudito e popular.

Assim, os contadores de histórias, na atualidade, se apresentam das formas mais diversas, tanto na escolha do texto a ser narrado, como na possível colocação de técnicas teatrais e/ou artísticas, nos empregos de uma ou mais linguagens, exigindo maior compreensão desses termos. Essa diferença entre os vários tipos de contadores, da atualidade, não tem sentido algum de hierarquia, mas sim, de atuar em contextos e objetivos diferentes. A diversidade de contadores de histórias encontrados na contemporaneidade é tema do próximo capítulo, em que será apresentado o sujeito dessa pesquisa, definindo qual contador estaremos tratando, nesta tese.

É com o pensamento de que "Educação é Cultura" (BRANDÃO, 1985), que trago o foco, agora, para a escola sem, no entanto, desmerecer outros campos educativos que, com certeza, refletem os acontecimentos dentro da escola e são espaços cativos de contadores, na atualidade. "Ninguém escapa da educação", nos diz Brandão (1995). Ela acontece em cada gesto humano que se instala num mundo concreto, em circunstâncias diversas e originais. É o sujeito, a pessoa humana, que faz a educação existir por seus atos, que respondem a uma situação concreta.

Educação é um processo simultâneo de transformar-se e de transformar o mundo, é realidade-processo que não pode ser considerada como coisa ou fato a ser descrita ou medida. Como realidade-processo, a educação permanece mudando, na construção do homem e da sociedade. Na escola, ou fora dela, a responsabilidade do educador é respeitável.

Porém, antes de explorar a diversidade de contadores da atualidade, continuo a discussão sobre educação e contadores de histórias, em uma pesquisa realizada na comunidade e outras experiências nas fases do ensino básico, campo em que foi construída minha experiência. 


\subsection{Os contadores de histórias na comunidade}

Embora a perspectiva da educação escolar seja foco desta pesquisa, considero que pontos de convergência entre as instituições de ensino e outras organizações da sociedade podem orientar ações dos contadores/educadores, sobretudo, na valorização das culturas locais. Ademais, os contadores de histórias, hoje, encontram espaços para suas atividades em bibliotecas, associações e organizações não governamentais (ONGs), além de teatros e casas de arte e cultura, muitas vezes, desenvolvendo projetos em parcerias com escolas, o que mostra como a atividade é inerente à educação, seja pelos valores que carrega, pela possibilidade de transformação do ser humano, ou pela capacidade de formação de público que pode promover. Seja qual for a intenção, o narrador oral consciente de suas ações saberá responder às questões, que, do meu ponto de vista ${ }^{28}$, são fundamentais, em qualquer ação educativa, neste contexto incluindo a contação de histórias. Que sociedade tenho? Que sociedade quero ajudar a construir? Com este pensamento, planejo e executo minhas atividades, seja na escola ou fora dela.

Contar histórias sempre foi uma atividade presente na vida em sociedade, tanto no cotidiano, quanto em solenidades, festas e rituais. Esse relato de experiência envolve contadores tradicionais, que também pertencem ao mundo contemporâneo, como eu, mas que, diferente de mim, nunca precisaram fazer ou ministrar cursos para outros contadores de histórias.

Nos anos de 1999/2000, quando tive a feliz oportunidade de morar em Pirenópolis ${ }^{29}$, Goiás, para escrever minha dissertação de mestrado, animada pelos estudos, de um lado, e pela empolgação e pedidos das amigas, de outro lado, reunimos um grupo para troca de experiências sobre essa história de contar histórias. E disso, renderam muitas histórias. Esse experimento foi de fundamental importância para a minha aproximação com os contadores tradicionais daquela

\footnotetext{
${ }^{28}$ Essas questões junto a outras na mesma direção, acompanharam minhas práticas pedagógicas desde o início, sempre conversadas e orientadas por minha mãe, Maria Helena Barcellos Café, professora de Filosofia da Educação, da UFG e PUC Goiás, a quem atribuo os sucessos que tive em sala de aula e o prazer de participar das lutas por melhoria na educação e todo o reconhecimento, por parte dos alunos, como mestra e professora, em várias homenagens.

${ }^{29}$ Pirenópolis é uma cidade turística do interior de Goiás, localizada no vértice de um triângulo entre Brasília e Goiânia. Isso a faz ser frequentada pelos dois públicos, que nos últimos quinze anos parecem ter descoberto a beleza da região, que foi tombada pelo patrimônio histórico. Apresentando uma arquitetura barroca, da época do Brasil colônia, a região é rica em cachoeiras e paisagens do cerrado, além de preservar uma das festas populares mais ricas da região: as Cavalhadas, uma das atrações da festa do Divino Espírito Santo.
} 
cidade e, consequentemente, ampliação do meu entendimento sobre o papel de um contador de histórias em sua comunidade, no reconhecimento da cultura local e no despertar do imaginário de quem ouve e de quem conta.

No início, reunimos um grupo, por coincidência ou não, só de mulheres interessadas na arte de contar histórias. Algumas queriam aprender como se conta uma história, animadas por me verem em alguns palcos, pelos bares da cidade. Outras ofereciam contatos com moradores da cidade, que se reconheciam como contadores de histórias. Eu poderia trocar experiências, oferecer meu tempo, meu repertório de histórias e um ouvido. As reuniões começaram a acontecer, com gente muito criativa e bem-disposta, com vários acontecimentos engrandecendo nossa experiência e ensinando o respeito e a admiração pelo que estávamos conhecendo e vivenciando.

Algumas pessoas desse grupo de amigas, formado em Pirenópolis (sem qualquer compromisso acadêmico) queriam conhecer as histórias de D. Benta, que andava sempre com Marieta, também narradora oral e poetiza, que me levaram ao conhecimento do $3^{\circ}$ contador, Seu Ico. Somadas às contribuições de Safia e Seu Bertoldo, formou-se, então, um grupo de cinco contadores, selecionados ao acaso, por ouvir falar que eles eram contadores de histórias, aqui e ali, pelas ruas e becos da cidade. Estes cinco contadores se apresentavam em sessões públicas e gratuitas, em diversos locais da cidade, durante nossa pesquisa. Resolvemos gravar as histórias, e isto foi conversado e pensado. Como seriam as primeiras aproximações, para que não houvesse interferências na naturalidade dos contadores?

A prática mostrou-nos que aqueles contadores de histórias participantes dessa pesquisa gostavam, e muito, de se apresentar e fazer sucesso! Havia certa vaidade ou disputa entre eles, pelo sucesso das histórias que contavam, de forma positiva e brincalhona. O prazer e a satisfação com que eles atendiam nossos convites para contar histórias em escolas, pousadas, cadeia, hospitais, fórum e praça pública nos deixava sempre emocionadas e empolgadas para continuar. As histórias eram ótimas e sempre bem recebidas! Valia à pena registrar.

A plateia era sempre misturada de crianças, adultos e pessoas de diversas classes sociais e origens, pois os turistas se misturavam aos moradores, garantindo um número reduzido para uma audição, sem uso da voz amplificada, o que poderia dificultar a adaptação desses contadores, ou perder o aconchego. Algumas dessas 
sessões de histórias foram apresentadas em treinamento de professores, de todo o Estado de Goiás, que nessa época, eram oferecidos aos professores, coordenadores e diretores de escolas pela Secretaria de Educação do Estado, na cidade de Pirenópolis. Nessa época, já havia chegado certo movimento de contadores de histórias, nas Secretarias de educação, incentivadas pelo $\operatorname{Proler}^{30}$, verificado na procura de professores interessados, após apresentações de histórias e em oferecimentos e pedidos de oficinas para contadores de histórias.

Uma das características no registro das histórias, nessa pesquisa que, por enquanto, recebe o título de "Contos do Arco da Véia", se manifesta na forma que as histórias foram gravadas: sempre em sessões públicas e gratuitas, organizadas pelas integrantes do grupo de pesquisa, preparada para plateias diversas, em locais também variados, alcançando moradores e turistas. Em momento algum os contadores narraram para o gravador ou para alguém do grupo de forma isolada. $O$ equipamento não foi pensado para uma qualidade de reprodução, mas apenas de registro do evento, e não da história. O objetivo maior não era a divulgação ou coleta das histórias, isso foi uma consequência, que considero uma boa descoberta!

Outra consideração é que a dimensão da história, na presença real de um público, se amplia pela cumplicidade da interação estabelecida entre ambos, por meio dos olhares, expressões do corpo e outros recursos. Em minha experiência, a presença do público, o olho no olho, propicia ao contador espontâneo a verossimilhança do conto. Nesse momento da pesquisa, observei que quando aconteciam imprevistos e interrupções, o clima de aconchego e cumplicidade garantia o entendimento da história. É nesse sentido que reivindico a necessidade de contar 'com' o público ouvinte, e não 'para' uma plateia, tema que será discutido, no decorrer da tese, como fundamento da presença do narrador oral.

Foram muitas histórias recolhidas em fitas k-7, que o grupo, da época, deu início a transcrições para que um registro escrito pudesse ser compartilhado pelos interessados. As regras de transcrição foram respeitadas, atendendo ao material de Aspásia A. de Camargo e Márcia B. M. Nunes, do grupo de estudos sobre o

\footnotetext{
${ }^{30}$ Proler - Programa Nacional de Incentivo à leitura, criado pela Fundação Biblioteca Nacional do Livro Infantil e Juvenil e Casa da Leitura, no início da década de 1980. Programa que chegou a muitas cidades, de todos os Estados brasileiros, pautado na parceria de instituições em cada localidade, na intenção da garantia de continuidade. Joinville, em Santa Catarina, está comemorando 20 anos de Proler, com um evento, em setembro deste ano de 2014. Com várias atividades de incentivo à leitura,esse projeto originou grande parte dos contadores de histórias da atualidade, pelo Brasil, inclusive o grupo Gwaya - Contadores de Histórias/UFG, do qual fiz parte, até 2005.
} 
desenvolvimento da ciência - GEDEC, associado à Superintendência de Memória e Patrimônio Cultural e Museu da Imagem e do Som de São Paulo, elaborado em 1977, por uma equipe da USP.

O material recolhido e transcrito, em parte, ficou guardado por um tempo, pelas dificuldades de políticas de financiamento, cujos editais contemplam apenas pesquisadores com doutorado. Entretanto, alguns alunos mais dispostos e curiosos tiraram a 'caixa branca' da estante, em que estava guardado o material e desenvolveram várias atividades. Essa mudança ocorreu quando fui dar aulas no curso de Artes Cênicas, cuja aproximação com a área me revelou um novo universo teórico, presente neste estudo, sobretudo, nas técnicas dos contadores desenvolvidas no último capítulo.

Entre transcrições e recriações das histórias, várias atividades foram desenvolvidas com o repertório coletado. Muitos alunos que fizeram parte do grupo de estudos e pesquisa da EMAC/UFG ${ }^{31}$, nos últimos oito anos, reescreveram sua versão e se aperfeiçoaram na arte de contar histórias, participando, também, de discussões para a possível edição do livro. O projeto de edição sempre foi adiado, por diversos motivos, aguardando uma oportunidade definitiva. No entanto, as consequências de todo esse processo são responsáveis por grande parte do meu amadurecimento, como formadora e contadora de histórias, pelas oportunidades de diálogos e trocas de conhecimentos e vivências com os participantes. Por esses motivos, exponho, aqui, as contribuições e aprendizagens que obtive com esses contadores tradicionais e todos aqueles que conviveram comigo, dividindo o tema e as experiências.

Durante o tempo em que estávamos organizando as sessões de histórias aleatoriamente, na cidade de Pirenópolis, surgiu, no MINC, o projeto Ação Griô ${ }^{32}$, dando oportunidade de remuneração, mesmo que pequena, às pessoas (mestres) da cultura popular, levando-as às escolas. O projeto Ação Griô Nacional é uma das ações do programa Cultura Viva, do Minc, que faz parte da demanda gerada pela Lei 10.693/03, que institui a obrigatoriedade do ensino sobre a cultura africana e

\footnotetext{
${ }^{31}$ Escola de Música e Artes Cênicas da Universidade Federal de Goiás, unidade em que atuo como docente, desde 2002.

${ }^{32} \mathrm{O}$ projeto Ação Griô foi assumido e desenvolvido pela Cooperativa Educacional de Pirenópolis COEPI (mantida pela Associação de Amigos de Pirenópolis) que recebeu a condição de Ponto de Cultura do MINC, por sua atuação junto à coordenação de Isabela Rovo, que aderiu ao edital do projeto, me procurando como parceira da UFG.
} 
afro-brasileira, que, por sua vez, fazem parte de um movimento maior de aceitação do outro e luta pela convivência e respeito com as diferenças entre as pessoas.

Por fim, posso afirmar que o movimento dos contadores, realizado na cidade de Pirenópolis, ainda hoje, proporciona consequências, tanto para os contadores que voltaram a contar histórias, quanto para o público que começa a procurar pelos contadores de histórias em várias situações. A cidade, hoje, abriga uma feira literária que, a cada ano, cresce em proporções, atividades e participações. No ano de 2014, a feira esteve inserida num evento maior: a Feira Internacional de Folclore.

Dos cinco contadores que participaram da pesquisa, em Pirenópolis, Marieta é, hoje, membro da "Academia Pirenopolina de Letras", reconhecida pela elite da cidade como poetiza. Dona Benta e Seu Ico já se foram, e deixaram suas histórias. Seu Bertoldo conta histórias aos netos e à família, quando se reúnem. Safia continua fazendo santos de barro e contando histórias, quando é solicitada.

As características das histórias que fizeram o repertório da pesquisa dos "Contos do Arco da Véia" são abordadas no próximo capítulo, junto à descrição dos sujeitos considerados contadores tradicionais.

Além desses espaços não governamentais e privados, o contador de histórias, hoje, no Brasil, atua profissionalmente em bibliotecas, clubes, livrarias, abertura de mesas em eventos acadêmicos, espetáculos de arte, saraus e festas, atendendo a públicos diversificados. A caracterização dos vários sujeitos que atuam nesses espaços, delimitando o sujeito desta pesquisa, constituirão tarefa do segundo capítulo. Antes, porém, pretendo explorar as ações dos contadores de histórias, nas escolas de ensino regular.

\subsection{Os contadores de histórias na educação básica}

Se narrar é uma arte, então pode ser ensinada.

Dora Etchebarne

O ambiente escolar não precisa ser duro, frio e sério para ser eficiente. A busca por uma educação de qualidade tem questionado a rigidez na educação escolar. Nesse sentido, a luta pela valorização da arte e da experiência lúdica, como 
fundamentos da educação humana e não como complementos supérfluos, tem merecido atenção e adesão. Em um momento em que o mundo pede criatividade, atitude e iniciativa para a resolução dos problemas que a vida impõe, o maior valor da educação passa a apontar para as teorias que aceitem e valorizem a autonomia e o protagonismo do aluno, estimulando respostas novas, como, por exemplo, o ensino de arte, na educação escolar. Não que considere a arte como solução de todos os problemas da educação, mas sua contribuição pode ser significativa para novas visões sobre o cotidiano escolar.

No Brasil, o ensino de arte, "obrigatório" na educação básica, modificado na última LDB (9394/96), não consegue atender as exigências da própria Lei, que determina formação em nível superior (Licenciatura), para atuação em cada uma das quatro modalidades de arte propostas: música, artes visuais, dança e teatro. Essa formação indica o atendimento ao ensino médio e às séries do 6ํa aำ ano, do ensino fundamental, e nem assim, temos o número de profissionais suficientes para 0 atendimento de toda a rede escolar ${ }^{33}$. O que acontece com a educação infantil e a chamada "primeira fase" do ensino fundamental, de $1^{\circ}$ ao $5^{\circ}$ ano? Quem Ihes propicia as primeiras experiências escolares no universo artístico, considerando que, para alguns, pode ser a única forma de acesso? Pela nossa legislação essa responsabilidade fica com os pedagogos, professores únicos que se responsabilizam pela educação integral da criança.

Entretanto, a formação em pedagogia tem se mostrado insuficiente para que o professor adquira competência e habilidades para o ensino de arte. Um dos fatores que corroboram para este contexto pode ser assim explicado: se o pedagogo não teve oportunidade de contato com referências, construções e manifestações artísticas, como poderá construir esse espaço para a criança? Como ensinar arte sem ter tido experiência prática com qualquer forma de arte? Os cursos e oficinas para professores pedagogos são reveladores da carência de atividades artísticas, pela atitude sedenta e pela inexperiência da grande maioria, nas atividades desenvolvidas, e as surpresas são constantes.

A partir de minha experiência na área, percebo que uma situação análoga acontece com os professores de educação física, cuja atuação sobre o universo da

\footnotetext{
${ }^{33}$ Após a homologação da LDB 9394/96, o MEC e as Secretarias de Educação deram início à vários projetos de formação de professores, em todas as áreas do conhecimento, por todo o país, presenciais e à distância (EaD). Mesmo depois de 18 anos e com todos esses cursos, ainda estamos longe de ter qualificação docente em todas as áreas.
} 
cultura corporal, em sua complexidade, exige vivência prática, que também não está presente na formação do pedagogo. Concluo, por meio das vivências nos planejamentos e cotidiano de escolas do ensino fundamental, por mais de 20 anos, que os professores têm dificuldades de lidar com a corporeidade dos alunos, provavelmente, por não ter desenvolvido a sua própria consciência corporal.

Há tempos noto e comento, em minhas oficinas para narradores, a diferença de comportamento entre os alunos de pedagogia e de licenciatura em educação física, isto, quando tive oportunidade de fazer oficinas em eventos acadêmicos, com exclusividade de público. Refiro-me à disponibilidade para mobilidade corporal. Enquanto os alunos de educação física gritavam, pulavam, ocupavam toda a sala e subiam, literalmente, uns em cima dos outros, os estudantes de pedagogia demoravam a explorar os espaços e sons, demonstrando maior facilidade nas compreensões do texto e exploração das palavras. Porém, isto é apenas uma observação isolada que não pode gerar generalizações, apenas sugere diferenças de experiências e oportunidades.

Aqueles que têm contato com manifestações artísticas da cultura popular, ou com artistas reconhecidos em sua família, ou no bairro, e aqueles que frequentam centros de artes ou participam, por vontade própria, de processos e produções artísticas, acabam se responsabilizando e contribuindo com a presença da arte na escola. Mas, há quem precise do ambiente da escola para o acesso ao que está fora da mídia, ou para o reconhecimento de manifestações artísticas pertencentes a sua e às demais culturas do país e do mundo. Nesse sentido a escola deveria se integrar mais com a comunidade local, como propôs a UNESCO, na década de 1960.

A falta de valorização e reconhecimento da importância da arte, na formação das crianças e jovens, e do papel da escola nessa formação, é aparente: na falta de formação desses pedagogos e licenciados; na falta de espaço e tempo adequados, destinado ao ensino de artes nas escolas; na falta de profissionais para concretizarem experiências artísticas; na escassez de material e disponibilidade para adquiri-lo. Tudo isso deveria ser revelado no Projeto Pedagógico de cada escola e nos currículos de todo o ensino básico. "Algumas escolas estão incluindo a Arte apenas numa das séries de cada um desses níveis (fundamental e médio) porque a LDB não explicitou que esse ensino é obrigatório em todas as séries" (BARBOSA, 2008, p. 13). Este é apenas um dos absurdos denunciados por Ana Mae. Em minha prática nos estágios, durante dez anos, pude ver aberrações 
semelhantes. Não raramente, encontramos escolas, no Estado de Goiás, em que o trabalho em grupo é proibido, de qualquer natureza, e para qualquer objetivo, e qualquer motivo para suspensão de aula, a de arte é a primeira a ser eliminada.

Por outro lado, minha vivência no cotidiano escolar, como professora e formadora, permite afirmar que nenhuma escola funciona sem a presença da arte. A crítica é justamente essa, de uma valorização utilitarista e velada em relação às atividades artísticas, fazendo com que valorizem as produções de alunos e professores, somente em datas comemorativas que, em sua maioria, atendem mais ao comércio do que a preocupação com a formação humana. De tal modo, a arte, na maioria das escolas, tem ficado limitada a esse tipo de produção, sobretudo, aquelas mais distantes dos grandes centros urbanos, onde se encontram legitimadas as atividades e produções de arte.

Em meio a todos esses problemas, presentes no modelo falido das escolas brasileiras e, ainda, outros que não foram mencionadas, há por outro lado, muitas tentativas e conquistas de experiências que dão certo. Alguns experimentos que colaboram para a valorização da educação escolar, por meio do trabalho com o contador de histórias, foram selecionados para mostrar suas contribuições. Com o olhar do contador de histórias voltado para o ensino de artes, respeitando as outras áreas, com outros pontos de vista, o professor de arte incentiva a descoberta dos alunos, propondo repertórios variados e uso de diferentes linguagens.

Em razão da diferença de formação do professor, para atuação nas fases de ensino, apresento, separadamente, cada uma das experiências dos contadores de histórias: na educação infantil, na atuação do pedagogo ( $1^{\circ}$ ao $5^{\circ}$ ano do ensino fundamental), e nas demais áreas da licenciatura, que atendem do $6^{\circ}$ ao $9^{\circ}$ ano do ensino fundamental e ensino médio.

\subsubsection{A educação infantil e o contador de histórias}

Era uma vez, um gato Pedrêz, Quer que eu te conte outra vez?! 
O encantamento demonstrado nos olhares e expressões faciais das crianças aparece junto com a pronúncia das três palavrinhas mágicas: era uma vez... E, mais adiante, os gritos e pedidos de: _ "Conta de novo...??' tão conhecidos por todos aqueles que se aventuram a compartilhar oralmente suas histórias, com os pequenos. O saldo é uma admiração recíproca, que me toma de emoção, me empurrando a contar cada vez mais histórias, para mais crianças. Essa característica inerente às crianças menores levadas pela curiosidade e pelo desejo de conhecer as coisas do mundo em que vivem, entusiasma os que sabem dar valor a essa convivência. Criança representa o novo, o improviso, o inusitado, pela espontaneidade que Ihes é peculiar. Entretanto, isso acontece com maior frequência, quando os ambientes frequentados pelas crianças propiciam e/ou instigam descobertas, estimulando aprendizagens, seja em casa, na escola, na rua, ou em qualquer outro lugar.

Com este pensamento, concordo com Kramer (2005) na importância da formação de professores que considerem as crianças como "sujeitos sócio-históricoculturais", seres da natureza, possuidores de especificidades, sendo necessário entendê-las e construí-las como cidadãs ${ }^{34}$ de direito, respeitando-as como tal.

A cada fase da vida, o ser humano se desenvolve de maneira a alargar suas experiências e conhecimentos, interferindo no mundo que o cerca. $O$ desenvolvimento da criança de zero a seis anos, que compreende a fase da Educação Infantil, em questão, é sintetizada na fala das professoras da UFMG, Vitória Farias e Fátima Salles:

\begin{abstract}
Elas se mostram ávidas por explorar esse mundo, na perspectiva de conhecê-lo, dele se apropriarem e terem a possibilidade de transformá-lo, ressignificando-o. Isso se realiza por meio de suas formas específicas de se apropriar da realidade, inicialmente por meio da ação física (pegando, mordendo, apertando, cheirando, experimentando, saltando). Posteriormente, ao adquirirem a linguagem, acrescentam a esse tipo de exploração a ação simbólica (imitando, falando, perguntando, brincando, desenhando, modelando, imaginando) (2007, p. 47).
\end{abstract}

Durante todo esse período, nas Instituições de Educação Infantil (IEI), é importante que sejam oferecidas oportunidades variadas às crianças, que, por sua

\footnotetext{
${ }^{34} \mathrm{O}$ conceito de cidadania que orienta minha prática é de Marilena Chauí, do livro: O convite à filosofia. A autora afirma que cidadania, no Brasil, é algo que precisa ser construído, pois em um país tão desigual em que os ricos têm privilégio e os pobres apenas os deveres, os direitos são uma luta permanente, parte da construção de uma sociedade mais democrática.
} 
vez, vão estabelecendo relações com as coisas e pessoas à sua volta, construindose sujeito de sua cultura. E, ainda que a linguagem seja desenvolvida depois da ação física, o estímulo por meio do uso da fala do mediador/professor com as crianças, facilita seu desenvolvimento e compreensão da linguagem. Anterior ao desenvolvimento da fala, a criança possui capacidade de entendimento, na maioria das situações em que está envolvida.

Em minha experiência na creche da $\mathrm{UFG}^{35}$, quanto menor a criança, mais curta a história, com ações concretas, pertencentes ao cotidiano da criança. A capacidade de compreender o que está ausente, ou seja, a capacidade de imaginar, pertence a uma fase posterior, com o aparecimento da capacidade de perceber, apreender e criar signos e símbolos, por meio da ampliação do vocabulário e compreensão dos significados das palavras e frases. Contar e ouvir histórias sempre esteve na rotina da creche da UFG, e era uma das atividades preferidas das crianças. Embora, nessa época, eu ainda não tivesse as referências e experiências que me construíram contadora de histórias profissional, instintivamente, contava histórias, cantava e estimulava as monitoras a verbalizarem todas as ações direcionadas às crianças, com a intenção de, embora de forma inconsciente, construir, como diz Girardello (2014) uma "Comunidade narrativa", no ambiente da creche.

Fui percebendo, claramente que as crianças mais velhas deveriam ter capacidade de se envolver com histórias mais longas, embora, nem sempre, isso se efetivasse. Ao longo do tempo a observação foi me revelando que o maior envolvimento com os contos são daquelas crianças que tem mais oportunidade de ouvir histórias e/ou participar de ambientes em que a fala era constantemente direcionada a elas. Notei, certa época, que a turminha de dois anos conseguia prender a atenção por mais tempo, gostando de histórias um pouco mais longas e querendo ouvir mais, em comparação às outras turmas. Não por acaso, nesta época tivemos uma estagiária, nesta turma, que contava sempre mais de uma história por dia. Algumas vezes, os contos eram contados outras vezes, e ela fazia leitura de livros e ainda improvisava com alguns objetos. Estava sempre conversando com as

\footnotetext{
${ }^{35}$ Fui integrante da equipe técnica que criou a Creche da Universidade Federal de Goiás, participando ativamente da elaboração de sua Proposta Pedagógica e funcionamento, nos anos de 1990 a 1993.
} 
crianças, ouvindo-as com toda a sua atenção e sugerindo algo a um grupo, ou apenas, verbalizando para a criança suas ações.

Neste sentido, fui percebendo que o tempo de duração da história, para ser contada, depende mais da experiência com a oralidade do que de seu desenvolvimento por idade. Assim, as classificações e indicações de contos, por idade, não pode ser considerado como único critério de escolha para o repertório de um professor, por exemplo. Quanto mais variados forem os contos disponibilizados às crianças da educação infantil, maiores serão as oportunidades de ampliação da visão de mundo dos envolvidos.

O desenvolvimento da narrativa amplia as possibilidades de interação entre sujeitos da cultura, ajudando a construir sua subjetividade. Auxilia na estrutura do pensamento, pela percepção da criança na estrutura, sempre fixa, presente nos contos, organizando conhecimentos e ações. Com a falta de tempo dos adultos, em relação aos cuidados das crianças, a tarefa cotidiana de contar e ouvir histórias, nas Instituições de Educação Infantis - IEls, torna-se imperativa, do meu ponto de vista.

Penso que, no mundo atual, frente ao processo de urbanização que insere adultos da família em longas jornadas de trabalho, ou, ao contrário, se fecha, mantendo-os à margem das sociedades, no desemprego, o afastamento entre crianças e seus familiares é inevitável. As IEls, no século XXI, são garantidas por lei (LDB: 9394/96), para todas as crianças, embora ainda não totalmente atendida pelas Políticas Públicas do país, tendo o papel tanto de cuidar como de educar, de forma integrada, como apontam autores que participam da construção da Educação Infantil no Brasil, como: Fátima Salles, Vitória Faria, Marília Guimarães, Solange Jobim, Sônia Kramer e outros.

\footnotetext{
Neste contexto, se dá, também, a entrada definitiva da televisão como o instrumento pedagogia cultural mais eficiente na formação das crianças, alimentando uma cultura consumista, passiva e muitas vezes nefasta à formação de valores (FARIAS e SALLES, 2007, p. 49).
}

A televisão, sem dúvida, é um grande e maravilhoso invento do ser humano, e pode auxiliar na tarefa do contador de histórias e de educadores, pois, como revela Marcuse em relação à técnica: "A técnica por si só pode promover tanto o autoritarismo quanto a liberdade, tanto a escassez quanto a abundância, tanto o aumento quanto a abolição do trabalho árduo" (MARCUSE, 1999, p. 75). 
Aplico esta referência à televisão, pela maravilha do invento eletrônico, e não pela forma com que vem sendo utilizado, no mundo contemporâneo. Muito menos advogo a substituição do ser humano pela "babá eletrônica", apenas concordo que como tecnologia é um recurso a mais de linguagem, para diversificar ainda mais as possibilidades do contador de histórias e do educador no mundo contemporâneo. Sabendo usar, pode contribuir com os instrumentos a serviço do professor.

Ao tratar a criança como sujeito, os adultos conversam normalmente com elas, combinando e recombinando as normas e regras de convivência coletiva, na medida em que as relações entre as crianças vão se ampliando. As contadoras e autoras Regina Machado e Gilka Girardello, assim como a grande maioria dos autores que escolho para apoio teórico, também criticam a fala infantilizada e diminutiva com crianças. Nesse sentido, não é necessário pedir silêncio com um discurso comprido, chato e quase incompreensível para os muito pequenos. Estes, antes de desenvolverem a linguagem da fala, interagem com os adultos por meio de sua linguagem corporal, da mesma forma que compreendem a linguagem corporal e a entonação do contador em ação. Ao ser questionada sobre como lidar com as interferências das crianças, durante uma contação de histórias, Regina Machado responde que: "O que eles chamam de interferência, eu chamo de participação" (MACHADO, 2004a., p. 81). Em minha experiência, não tem nada que interfira mais negativamente do que as próprias professoras ou monitoras tentando exigir o silêncio e atenção das crianças, quando elas próprias estão com o pensamento em outros lugares, ignorando, por completo, a história que está sendo contada. Muitas vezes, o contador é aceito na escola para que o professor possa "descansar", da difícil tarefa de educar ${ }^{36}$. Entretanto, o contador de histórias que interage com seus ouvintes sabe exatamente como lidar com situações imprevistas, improvisando. Para isso, conhecer os princípios que regem suas ações, para distinguir as consequências de seu fazer, é um dos fundamentos da prática do contador de histórias que se encontra em construção.

Certa vez, em um curso de contadores de histórias, me perguntaram como eu preparava os pequenos para ouvir minhas histórias. Passando a observar minha prática intuitiva, porém refletida e muitas vezes transformada, percebi que meu comportamento dependia muito mais do ambiente em que eu me encontrava, do que

\footnotetext{
${ }^{36}$ Infelizmente essa é uma realidade presente, frente a enorme complexidade de problemas que a educação brasileira vem enfrentando, por falta de investimento e valorização suficientes.
} 
de uma maneira única e específica. Na primeira oportunidade, me descobri entrando em contato com as crianças por meio de brincadeiras, músicas e parlendas, com o sentido de recuperar a espontaneidade delas, favorecer a manifestação lúdica e distanciá-las dos pedidos tradicionais, em que a participação se torna ameaça das cuidadoras.

A resposta a esta questão passa pelo entendimento da relação educativa que fundamenta a prática de cada contador. A reflexão me leva a compreender que, ao utilizar como fundamento a interação com o ouvinte, dando significados individuais e/ou coletivos às narrativas, o contador de histórias nota na linguagem corporal dos ouvintes, sobretudo, por meio dos olhares, suas expressões de compreensão e acompanhamento na história, ou quando se mostram perdidos, tentando recuperar uma informação ou um detalhe. Cabe ao contador perceber e, sem perder o fio da história, assegurar a compreensão dos ouvintes, segundo Regina Machado, estar presente, sentir todo o clima do ambiente, participar:

\footnotetext{
Estar presente é saber o que dizer para cada criança quando ela faz comentários durante a história. Para uma é preciso sorrir, para outra responder. Uma terceira só quer compartilhar o que a história está dizendo, outra quer chamar atenção, ou não consegue parar quieta (MACHADO, 2004a., p. 81).
}

Reconhecer a criança como sujeito significa respeitá-las, todas, cada uma em sua condição, respondendo dentro do possível e do respeito à história, sem interromper àqueles que estão acompanhando sua estrutura. Ao admitir que a compreensão da criança seja distinta, aceitamos, também, reações variadas, cuidando para que o respeito e a alteridade prevaleçam.

Faria \& Salles (2007), ao discutirem as questões do currículo e os elementos que compõe uma Proposta Pedagógica, na Educação Infantil, reconhecem o funcionamento interdependente das linguagens, apontando a primeira infância como a fase em que esta se estrutura. A linguagem é a "capacidade humana de compartilhar significados que nos constitui e nos possibilita elaborar e partilhar a vida com os outros, apropriando-se da cultura, produzindo-a e transformando-a" (FARIAS e SALLES, 2007, p. 62). Portanto, o desenvolvimento das linguagens, nas IEls, é o centro do ensino/aprendizagem, por se dar nesta idade "as aquisições mais importantes relativas ao desenvolvimento da linguagem oral" (ibidem, p. 63). Com o desenvolvimento da função simbólica, "a linguagem passa a comunicar o mundo 
interno e permite a criança sair do tempo imediato e do local presente", (ibidem, p. 63). Além da capacidade de linguagem poder ampliar a visão e entendimento de mundo, pela criança, é expressando sua compreensão em relação às coisas, por meio da oralidade, que o adulto pode perceber sua compreensão e interferir, ampliando suas potencialidades.

Girardello, em artigo publicado na revista Signo - UFSC, conclui, em sua pesquisa, que "nunca é cedo demais para começar a contar histórias para as crianças" (2014, p. 9). Portanto, assumo que a narração de histórias para crianças pequenas nas IEIs deveria fazer parte do planejamento e da rotina diária dessas crianças menores. Infelizmente, os profissionais envolvidos com esta faixa etária, nem sempre, estão preparados para reconhecer essa importância, ou para desempenhar esta função.

\subsubsection{0 ensino de arte do $1^{\mathrm{o}}$ ao $5^{\mathrm{o}}$ ano do ensino fundamental}

Quem escuta uma história

está em companhia do narrador; mesmo quem lê partilha dessa companhia.

Walter Benjamin

Nesta fase do ensino fundamental, as crianças estão um pouco maiores e carecem de adquirir maior autonomia, e isso envolve desembaraço e maior domínio das linguagens, para dar conta dos novos conteúdos e desenvolvimentos inerentes à idade. As crianças de seis a dez, ou onze anos pertencem ao período da infância em que é importante considerar sua fase de ampliação das descobertas do funcionamento do mundo e das coisas do mundo. A maneira pela qual a escola se estrutura, nesta fase, dá início a uma fragmentação que se estende a todo o ensino básico. Esta fragmentação tem sido pano de fundo de muitas discussões direcionadas aos modelos da educação escolar vigente, em seu esgotamento atual. Assumindo a necessidade de superação deste modelo falho da educação escolar, no Brasil, reconheço no ensino de arte possibilidades concretas de mudanças significativas, no cotidiano escolar, com vistas às mudanças no processo e resultados da formação dos alunos. Mas, com a utopia que pertence aos crédulos, 
seria importante e talvez necessário que todos pudessem, um dia, vivenciar uma experiência artística, não só como espectador, mas também, como produtor de arte. Infelizmente, a maioria dos professores que atua com essa fase de ensino parece não ter tido oportunidade, nem em seu tempo de criança na escola, nem em sua formação na pedagogia.

Essa afirmação pode ser constatada nas experiências de oficinas e cursos de formação que ministrei para contadores de histórias, observando que a grande maioria dos professores já formados, ou ainda, em formação, demonstravma sua distância com as experiências narrativas. As dificuldades dos alunos/professores aparecem: ao lidar com processos criativos; no repertório a ser escolhido; por não terem a consciência de que conhecem alguns contos tradicionais; por conhecerem pouco, tanto a literatura infantil, como também o seu próprio potencial de criação; no uso da linguagem corporal como recurso narrativo; ao saberem o momento em que a história poderá ser apresentada, garantindo o deleite à arte, sem cobranças posteriores; ao utilizar a contação de histórias como contribuição subjetiva, sem preocupações de como esta interfere na formação de cada aluno ou pessoa que está ouvindo a história; sobretudo, ao propor jogos e brincadeiras, considerando-os como parte séria na educação escolar. Parte de minha trajetória se direcionou para a minimização dessas dificuldades nos objetivos dos cursos e oficinas para professores.

Outro ponto que tem sido bastante discutido nas rodas e encontros de contadores de histórias é a atividade de contação de histórias como incentivo ao letramento, parte da alfabetização, destinada à decodificação dos signos, segundo Emília Ferreiro ${ }^{37}$. Há uma polarização na discussão sobre a contação de histórias como incentivadora da leitura. Em outras palavras, há quem não acredite que a oralidade influencie, de alguma forma, a apreensão da leitura e da escrita. Posiciono-me com aqueles que acreditam que as histórias ampliam a visão de mundo de quem ouve e conta, apontando possibilidades e usos de várias linguagens e, isso sim, estimula a curiosidade pela escrita, como pode ser confirmado por Girardello, em sua Tese de Doutorado:

\footnotetext{
${ }^{37}$ Emília Ferreiro é educadora e alfabetizadora, tendo contribuído com muitas obras a este respeito, conhecida e bastante adotada em todo o Brasil.
} 
É ouvindo histórias (lidas ou contadas livremente, inspiradas na literatura ou na experiência vivida) e vendo ouvidas as suas próprias histórias que elas vão aprendendo a tecer narrativamente sua experiência e, ao fazê-lo, vão se constituindo como sujeitos culturais (GIRARDELLO, 1998, p. 92/93).

Reconhecer sua própria história e conhecer a história dos outros pode fortalecer as comunidades narrativas, dentro das escolas. E, acredito que ao se reconhecer sujeito de uma sociedade letrada, as necessidades da escrita e da leitura passam a ter um valor inerente.

Ana Maria Machado e Ruth Rocha, em seu livro: Contando histórias, formando leitores (2011), escrito em forma de diálogo, contam como foram influenciadas pelas mães e família, cada uma de um jeito, alcançando a condição de leitoras e escritoras reconhecidas, como são, hoje. Ana Maria Machado, professora de literatura, tradutora e, mais tarde, escritora de literatura infantil, avó e contadora de histórias, conta que muito de sua inspiração veio de sua mãe, sempre lendo (até quando mexia a panela), de bons professores e bons autores. "O contato com um bom autor é um momento de revelação, de epifania de abertura para infinitas possibilidades de linguagem" (MACHADO e ROCHA, 2011, p. 23). Foi por influência da família e da escola que a autora seguiu sua carreira nas letras. Ruth Rocha pertence a uma geração anterior, que valorizava a leitura. Era filha de nordestino contador de histórias, também se tornou escritora de literatura infantil e juvenil, bem conhecida e divulgada nas escolas, com dezenas de publicações.

Para Ruth Rocha, a importância de se ouvir, ler e contar histórias na escola "reside no fato de que a criança, o jovem, vai formando um padrão dos acontecimentos da narrativa" (MACHADO e ROCHA, 2011, p. 14). Acredito que a estrutura da história ajuda a criança a organizar as ideias e pensamento, dando condições para que ela crie e organize outras histórias. As leituras, em diferentes linguagens, mobilizam aspectos humanos diferentes, provocam o imaginário, que é constituído por meio das experiências e vivências individuais e coletivas.

Em orientação de estágio curricular, certa vez, duas alunas desenvolveram suas práticas de ensino em uma sala de aula de $1^{\circ}$ ano do ensino fundamental ${ }^{38}$, no CEPAE/UFG. Elas trabalharam com a professora de sala de aula (pedagoga), por

\footnotetext{
${ }^{38}$ Frente a inexistência na época de aulas de teatro na grade curricular e falta de professores com formação específica em teatro, fomos construindo um estágio dentro das possibilidades que apareciam, com os professores de outras áreas que aceitavam dar aulas de arte, mediadas pelas estagiárias. Agradeço a colaboração de muitas professoras que aceitaram 'emprestar' sua turma para a vivência das estagiárias, alunas de Licenciatura em Artes Cênicas da UFG.
} 
não existir professor de teatro na escola, nessa época, conquista que se deu no ano seguinte.

Com um projeto de intervenção planejado para oito aulas, em que a liderança seria revezada entre as alunas, elas escolheram o tema: da contação de histórias ao teatro, e vice-versa. Primeiro, escolheram quatro histórias, com orientação da professora de sala. Duas delas seriam, primeiro, contadas por elas, com o livro, para, em seguida, serem propostos jogos dramáticos ${ }^{39}$ que levariam à encenação da peça pelas crianças. As outras duas narrativas seriam, primeiro, encenadas, para depois, serem recontadas pelas crianças. O objetivo era experimentar e estimular, tanto a arte dramática, quanto a narrativa oral, como formas de participação e interação coletiva, inaugurando a experiência de sala de aula das duas estagiárias, em seu exercício de formação para professores.

A consequência foram dois Trabalhos de Conclusão de Curso (TCC) que partiram de um mesmo objeto, a prática de ensino, chegando a resultados totalmente diferentes, mostrando a variedade de possibilidades para a contação de histórias, em aulas de arte. Um dos trabalhos teve o foco em duas crianças, dessa mesma sala, com o diagnóstico de Déficit de Atenção e Hiperatividade - TDAH. O aluno que se apresentava mais comprometido, que aparentemente não conseguia prender atenção em nenhuma atividade, ficou durante uma aula inteira debaixo da mesa mordendo uma borracha, enquanto uma das estagiárias contava uma história. $\mathrm{Na}$ aula seguinte, a outra estagiária que somente observava, pediu para permanecer na sala e conversar com o referido aluno. Com um desenho para colorir, do personagem da história, a aluna/professora perguntou, descompromissadamente, à criança se ele queria colorir, ou desenhar. O aluno, imediatamente, 'avançou' no papel e na caixa de lápis e começou a colorir cada pedaço da barriga do burro (personagem maior do desenho), de uma cor diferente. Ao ser indagado sobre o que estava fazendo, ele recontou toda a história, mudando as cores do lápis a cada trecho da estrutura narrativa.

A conclusão da aluna é de que as histórias invadem o imaginário da criança, que quando instigada, responde aos estímulos propostos. Às vezes, não sabemos como estimular as crianças, na ansiedade de querer respostas já pensadas por nós

\footnotetext{
${ }^{39}$ Com base nos Jogos Dramáticos de Peter Slade.
} 
mesmos. Quando simplesmente ouvimos o que a criança tem a dizer são comuns as surpresas e admiração por sua capacidade.

O outro trabalho apontou os efeitos e possibilidades da manifestação lúdica, dentro da sala de aula, nas atividades criadas, tanto partindo da história para a dramatização, quanto ao contrário. Uma conclusão respeitável desse segundo trabalho "é a importância de um professor acreditar na melhora da educação, ter consciência de que a mudança só acontece se a gente decide começar", segundo fala da aluna. Então, concluímos juntas que o professor ao fazer suas escolhas com base no que ouviu das crianças, terá mais chance de acertar, por conseguir se aproximar mais da criança. "Junto com a criança, constrói-se a sabedoria e vivenciase uma partilha emocional. $E$ disso cresce o indefinível conhecimento da vida que constitui para a criança em educação no mais completo sentido da palavra". (SLADE, 1978, p. 42). Novamente, aparece a necessidade de ouvir o aluno e considerar sua participação ativa, com autonomia.

A avaliação da professora da escola sobre o projeto de estágio das alunas foi positiva, ao considerar que as atividades são prazerosas para crianças e professores, estimulando até aqueles que raramente participavam. Entretanto, permaneceu a velha queixa de que: "fica pouco tempo para as atividades de escrita, que nessa fase, tomam muito tempo - justifica, meio sem graça - e 'brincar' acaba ficando para depois".

Em minha visão, criança na escola precisa do desenvolvimento de todas as linguagens, a fim de conseguir se expressar e viver em sociedade. Talvez, uma grande contribuição do ensino do teatro, nessa fase, seja por este lidar com muitas linguagens, estimulando, inclusive, a escrita, por meio do incentivo ao conhecimento de autores que marcaram a história, como Shakespeare, Ariano Suassuna ${ }^{40}$ e tantos outros...

Outro ponto, quase sempre presente na preocupação de professores que começam a levar o contador de histórias para a sala de aula, é a repetição de uma história. Chegam a me perguntar quantas histórias tem que ser contadas por semana. Ora, acho que todo dia deveria ser dia de histórias! Alguns dias com um tempo mais comprido e outros mais curtos. Dá para negociar? Não precisa ter sempre história nova. Contar de novo é como fortalecer a curiosidade daquele que

\footnotetext{
${ }^{40}$ Cito apenas esses dois autores, como referência que foram para essa turma da qual participaram as alunas estagiárias, sem qualquer intenção de destaque aos autores.
} 
pede para reviver uma emoção, ou visitar uma imagem, provocada pelas palavras do narrador oral. Por outro lado, há que se considerar que a criança também é contadora e, se existe algum espaço para isso, a aula de arte deveria ser um deles.

\subsubsection{O ensino de arte do $6^{\circ}$ ao $9^{\circ}$ ano do ensino fundamental.}

A arte de contar tem estreita relação com o dom de ouvir: quando se estingue a experiência narrativa, desaparece também a comunidade de ouvintes.

Bia Bedran

A partir do $6^{0}$ ano do ensino fundamental até o final do ensino médio, o professor licenciado é o responsável por cada uma das disciplinas ofertadas nas escolas, vinculadas à sua formação específica do ensino superior, determinando a fragmentação do ensino, que se estende em todas as fases. Este modelo cartesiano de pensamento, ainda predominante nas escolas brasileiras, faz com que cada um se preocupe com seu conteúdo, perdendo de vista a construção dos valores mais humanos, sobretudo o valor da alteridade. Nesta fase de desenvolvimento, os préadolescentes e adolescentes tem demonstrado dificuldades em situações que exigem escuta prolongada, ou em situações do uso de uma fala articulada e estruturada, explicada em parte pela velocidade com que o mundo vai se transformando e colocando novas informações à disposição.

Acredito que a dificuldade de escuta e atenção, por parte dos alunos, reclamada nas escolas, denunciadas por professores e pesquisadores, possa ser minimizada pela constituição de um hábito cotidiano de ouvir e contar, conquistado por meio de estímulos como: contar histórias em vários espaços e eventos, planejados e improvisados. Isto é, todos na escola deveriam (pelo menos experimentar, um dia) contar histórias - direção, coordenadores, professores, alunos, faxineiros, merendeiros, guardas, pais da comunidade escolar, ou seja, todos da comunidade - valorizando a oralidade, dando voz a quem se apresenta, ouvindo e participando, comungando da vida coletiva, segundo Girardello (2014), pela formação de uma "comunidade narrativa". Talvez essa seja a maior utopia da educação escolar: 'todos os educadores preocupados com a formação do ser 
humano, sem considerar este ou aquele conteúdo como mais importante que o outro'.

Para o fortalecimento dessa comunidade narrativa, Girardello (2014) apresenta alguns passos de sua experiência que podem orientar e despertar outros estímulos. Segundo a autora, contar experiências na $1^{\underline{a}}$ pessoa encoraja os alunos pelo sentimento de cumplicidade que se forma. "Emociona o modo como as crianças respeitam a coragem dos colegas, como ouvem em silêncio solidário. Não é um silêncio disciplinar, mas íntimo e fraterno" (GIRARDELLO, 2014, p. 86). Já vivenciei esses momentos, 'de enxugar os olhos', em salas de aula com idades variadas, confirmando a cumplicidade dos colegas, no silêncio, na prontidão e na emoção da escuta.

Outra sugestão da autora é de que "não basta a visita de um contador de histórias profissional em ocasiões especiais" (ibidem, p. 93), o contar sempre é que forma e fortalece uma comunidade narrativa. E na continuidade de seus exemplos, Girardello (2014) indica alguns estímulos que podem ser estendidos para as aulas de arte: escrever com base ou apoio na palavra oral (parte do cotidiano); contar, ou recontar histórias baseadas em livros, num processo posterior, depois de instalada a leitura; atenção aos resultados diferenciados entre as atividades, considerando a utilização de linguagens diferentes. Eu acrescento para aulas de arte: brincar com as histórias individual e coletivamente, utilizando várias linguagens em sua composição, como movimentos corporais, sons e vozes diferentes em uma única história, objetos que se transformam em outros, enfim, estímulos para a criação diversa dos alunos em sua ação de contar.

Participei, certa vez, de um projeto da Secretaria Municipal de Educação, em parceria com a Guarda Municipal de Goiânia, cujo objetivo era humanizar os agentes que trabalhavam nas escolas públicas da cidade. Para tal objetivo, planejaram, dentre outras atividades, um curso de contadores de histórias, com 20 horas de duração, ocupando todas as manhãs ou todas as tardes, em uma única semana. As regras vieram prontas da Secretaria, porém, a prática mostrou a necessidade de ter certa liberdade, verificando cada contexto e as devidas adaptações. Nesta época, eu pertencia ao grupo Gwaya - Contadores de histórias/UFG e, ao atendermos o projeto, as turmas foram divididas, incumbindo a mim duas escolas, em local e turno diferentes. 
A estrutura do projeto envolvia, por escola: dois guardas municipais, quatro professores da escola (com papel de alunos) e 35 alunos do $6^{\circ}$ ao $9^{\circ}$ ano do ensino fundamental, a escolha da escola, durante todo um período, em um total de 41 alunos em sala de aula para aprender a contar histórias. O desafio estava formado!

As duas escolas foram visitadas por mim, para a escolha da data, dos alunos, enfim, os últimos ajustes para o início do curso. A sala de aula era bastante diferente da tradicional, não só pela mistura dos alunos advindos de várias séries, como pela presença de guardas e professores com o papel de alunos, misturados aos adolescentes. A aprendizagem construtivista ${ }^{41}$ acolhe e valoriza a presença de alunos diferentes em uma turma única, por aceitar que a aprendizagem se dê pela mediação dos mais experientes. Os resultados das duas escolas foram muito diferentes entre si, trazendo reflexões que podem contribuir para ampliação e permanência do contador de histórias no cotidiano das escolas.

As duas escolas se localizam na periferia de Goiânia, embora em extremos opostos de sua localização física, e realidades, também, muito diferentes. $\mathrm{Na}$ primeira escola, fui atendida pela coordenadora, que marcou a semana do curso para uma data em que ela estaria de licença. Quando a direção da escola me recebeu, já no primeiro dia do curso, não sabia do que se tratava. Depois de rodar a escola, por quase meia hora, para ver quem sabia do projeto, descobrimos uma professora separando os alunos. Convidada a esperar na sala dos professores, por quase uma hora, enfim, chegou o momento tão esperado do contato direto com os alunos. Acompanhada por duas alunas da UFG, participantes do grupo de pesquisa, na época, entramos na sala e fomos recebidos sem animação alguma, por parte dos alunos. Os guardas não estavam presentes, também não havia professores, como o previsto, e os alunos foram selecionados como se fossem para um castigo. Ficamos sabendo disso na hora do lanche, puxando assunto com um grupo de meninas.

Entendemos o recado, escolheram os piores alunos, aos olhos deles. O que não era esperado era que essa turma ganhasse um presente, pois passaram uma semana de diversão na escola. E, como eram alunos que não se adaptavam ao modelo tradicional daquela escola, nossa aula foi atraente, e, talvez, tenha contribuído com estímulos para que voltassem a procurar por alguma leitura.

\footnotetext{
${ }^{41} \mathrm{~A}$ aprendizagem lúdica construtivista, com base nos estudos de Vigotsk, Leontiev, Lúria e Wallon, foi o estudo desenvolvido por mim, em curso de especialização na UFG, sobre a orientação da Professora Drª Ivone Garcia; conceitos que procuro colocar em prática no exercício da docência.
} 
Os alunos, em geral, tinham muita dificuldade de se organizarem, pouquíssimos sabiam ler, apesar de ser turma do $6^{\circ}$ ao $9^{\circ}$ ano, mas eram receptivos e, aos poucos, foram percebendo que não apontávamos erros, e sim, observações para melhorar a performance da contação, se o aluno pedisse. Considero uma semana pouco tempo para grandes mudanças, mas, é suficiente para sentir que a possibilidade é real. Essa era a intenção do trabalho, contribuir com a inserção da contação de histórias na escola, de forma que dessem continuidade de alguma forma.

Reconheço, hoje, que a tentativa do projeto era fundar uma Comunidade Narrativa $^{42}$ na escola, como me esclareceu Girardello (2014). Porém, o ambiente dessa primeira escola, cujo turno do curso foi o matutino, não estava preocupado com a educação, ou convivência dentro da comunidade escolar. Como falar de encantamento, de imaginário e emoções diversas em um ambiente em que um "Bom dia!" era totalmente ignorado? Como valorizar uma narração ou um diálogo, em um espaço que só havia mandos, ameaças e desconfianças?

Durante toda a semana, chegamos sempre no mesmo horário, tendo que esperar por mais de cinco minutos para abrir a escola, por três vezes. A justificativa da diretora foi a necessidade de manter a chave sob seu poder e fazer fiscalização nos muros da escola, logo no momento da entrada dos alunos, pois os traficantes ${ }^{43}$ passavam a droga pelos buracos feitos nos muros da escola. Quanto aos professores, nunca participaram de nenhuma atividade. Limitavam-se a entrar na sala para pegar algum material ou para algum recado, nem sempre respeitando a atividade em desenvolvimento, sobretudo quando a fala estava em posse do aluno. Confesso nunca ter visto tamanha falta de respeito juntos em um mesmo local. Mas, tenho certeza de que não era percebido assim, por quem cometia tal ato.

A normalidade com que são tratadas certas transgressões, em nossa sociedade, é espantosa, observada, por exemplo, nos absurdos e abusos de poder dos professores, desta escola. No primeiro dia, tendo que esperar na sala dos professores, conheci o "comércio paralelo" que movimentou as professoras, durante toda a semana, tirando-as de sala de aula. Ao passear pela escola, no primeiro dia, para procurar os alunos, e nos outros dias, para conhecer os espaços e saber onde

\footnotetext{
${ }^{42}$ Tema que será retomado no quarto capítulo.

${ }^{43}$ O problema de droga na região é crônico e apesar de ser reconhecido pela imprensa e pelas autoridades, nada é feito para minimizar a situação. A Diretora chegou a me mostrar o saco de cimento que usava, todos os dias, para tapar os buracos que eles tornavam a furar, todos os dias.
} 
poderíamos ocupar, sem interferir nas atividades cotidianas, me deparava sempre com professores conversando na porta da sala de aula. O assunto era o 'comércio' da sala dos professores. E dentro das salas, os alunos fazendo cópias.

A prática da cópia de conteúdos do quadro branco ou quadro giz, foram por mim questionadas, sempre que tive oportunidade, pelo excesso de vezes em que me deparei com essa realidade, me sentindo muito incomodada. Como pesquisadora e conhecedora de meu objeto, fui colecionando respostas sobre o que os professores e coordenadores das escolas pensavam da cópia de conteúdos, como atividade que ocupava a maior parte do dia da criança nas escolas. As respostas elencadas foram ordenadas, conforme maior número de respostas, em um total de 73 contabilizadas. Anotando, sempre, em meus diários de campo, colecionei respostas como: forma de repassar ou revisar conteúdo que vai ser cobrado na prova; tem que copiar para aprender; substituir professor que faltou; ocupar os alunos porque estão muito agitados; castigo, para descontar um monte de coisas erradas que fazem da escola um péssimo ambiente de trabalho. Não falo contra a cópia em si, pois como técnica de aprendizagem pode ser muito válida.

A falta de comprometimento (compromisso mais conhecimento) desses professores se reflete na desorganização dos alunos em sala de aula. Mas, existem outros fatores que conseguem ainda piorar esta situação. A questão do espaço físico, no meu entender, é uma questão grave, de complicada adequação, por exemplo, no número de alunos para o tamanho das carteiras e da sala. A tentativa de formar um círculo, que para mim inicia o ritual do contador de histórias, em razão de dar às pessoas o mesmo grau de visibilidade, vai por água abaixo, pois o espaço só permite um círculo duplo, isto é, metade dos alunos, ao olhar para frente, permanece com a visão da sala de aula tradicional, ou seja: a nuca do colega.

O círculo inaugura, como que por 'um passe de mágica', ou por uma intenção lúcida de quem promove a liberdade, a troca de experiências, sem precisar considerar alguém, à frente, melhor do que os outros. Essa equidade de tratamento, na sala de aula, é fundamental para o exercício da expressão oral. O aluno não pode sentir-se diminuído, para que não tenha vergonha de falar, de se expressar. Ao tentar procurar outros espaços na escola para o trabalho do contador, fomos impedidos, com o fundamento de que desorganizaria a escola.

$\mathrm{Na}$ continuidade do curso, outro problema foi detectado, sem chance de solução. A participação da dupla de guardas da escola era trocada, a cada dia, de 
acordo com o plantão, fato que deveria ter sido observado e solucionado pela parceria das secretarias. O prejuízo fica na falta de continuidade do curso, em detrimento dos vínculos que poderiam ser formados, se não com os professores, pelo menos entre guardas e alunos. Ficou uma séria falha na atividade dos guardas, que perderam continuidades e finais de histórias. Outro problema com os agentes em sala, junto aos alunos, foi a dificuldade que tiveram de entender, ou aceitar, que naquele momento não havia hierarquias, todos ali tínhamos os mesmos direitos (inclusive eu e as estagiárias). Assim, alguns exercícios de duplas foram burlados pela dificuldade do policial em obedecer a um aluno. Como um dos fundamentos de minha sala de aula é a ludicidade, manifesta por meio do jogo, não teve a menor importância a dificuldade de participação dos guardas, para a continuidade das atividades. Às vezes, um comentário e um sorriso, na intenção de que seja possível, um dia, a compreensão de que a autoridade pode ser construída, justamente na aprendizagem da obediência à regra, no interior do jogo. Para quem estuda este tema, "o jogo é ordem e cria ordem" (HUIZINGA, 1971). Essa dificuldade dos guardas em criar estratégias para superas as regras de um jogo e aceitarem quando estas os fazem inferiores ao aluno, foi o ponto de maior coincidência entre as duas escolas.

A outra escola, completamente diferente, não tinha problemas de droga, na vizinhança, o espaço físico era privilegiado, tendo, inclusive, sala de artes e laboratório. A Diretora tinha formação em Educação Física e tinha sido minha colega de faculdade. Prestou-me esclarecimento de que, no município, cada escola tem certa autonomia em sua gestão. O fato de uma escola ser melhor ou pior, ter mais ou menos material que outra é um problema específico de boa ou má gestão. Em Goiânia, a eleição direta para diretores de escola foi uma das primeiras, no país, ainda que se efetive em apenas alguns governos.

Embora a dificuldade dos guardas nas atividades de submissão aos alunos tenha acontecido também, nessa escola, as atitudes carinhosas dos alunos ao perceberam suas dificuldades foi o diferencial entre os resultados das duas oficinas. Nesta segunda escola, atendendo ao turno vespertino, já existia um projeto e um grupo de contadores de histórias que ficou radiante com a notícia da oficina. Achei interessante saber que, apesar de desenvolver projeto na área, ninguém achou que teria mais direito que os outros da escola, sobre o curso de contadores. Os critérios para e seleção e preenchimento das vagas de participação na oficina de Contadores 
de Histórias foram construídos com base em discussões entre os alunos da escola e professores que ajudavam a mediar os debates, ou seja, uma escola que respeita seus alunos e consegue um clima agradável em seu cotidiano.

Confesso que não foi nada fácil entrar em uma sala de aula com 42 pessoas, com tamanho igual ao da escola anterior, dois círculos de carteiras para caber todo mundo, mais uma vez, para desenvolver algo em torno do contador de histórias. Mas, o sorriso no rosto com que fomos recebidas apaga da memória qualquer defeito presente. Este trabalho foi delicioso! A criatividade dos alunos, o deliciar-se, quase infantil, das professoras e a participação parcimoniosa e, ao mesmo tempo, carinhosa dos guardas, rendeu importantes conquistas e reflexões em torno do contador, não só no ensino de arte, mas como em toda a escola, por meio de sua natureza interdisciplinar.

O mais importante é a permanente atitude reflexiva do professor, análoga ao contador de histórias, cuja responsabilidade é conhecer as consequências de seus fazeres. Saber o que se faz, para quem se faz e como se faz, são atitudes de um contador de histórias que se reconhece na tarefa educativa, inerente à contação de histórias.

A sistematização das experiências apresentadas, considera a formação profissional como foco, no qual os licenciados em arte/teatro são formados para atuarem nessas duas fases do ensino, de $6^{\circ}$ ao $9^{\circ}$ ano e no ensino médio. Assim, continuo com a apresentação de experiências, em cada fase da educação escolar.

\subsubsection{O contador de histórias no ensino médio.}

A intenção é o que move e dá sentido à experiência de contar histórias.

Regina Machado

Quem é o aluno de ensino médio? Em que fase de desenvolvimento se encontra e como tem sido tratado? Qual a sua relação com as coisas do mundo? E, como o professor entende essas relações? Quais intenções podem contribuir com o ensino de arte, por meio do contador de histórias? 
Nesta fase do desenvolvimento, o adolescente já é capaz de desenvolver muitas tarefas com autonomia, em um nível profissional, considerando alguns setores da sociedade, além da obrigatoriedade dos estudos serem válidas até o 9ำ ano do ensino fundamental. O ensino médio alcança aqueles que querem ter acesso ao ensino superior, ou desejam aprofundar seus estudos, seja por necessidade pessoal ou obrigação social. As histórias pessoais podem ser um bom convite ao conhecimento do mundo dos contadores de histórias, além de funcionarem como excelentes gatilhos para incentivar a pesquisa de outras histórias, estimular ouvintes e registros escritos.

Certa vez, ao acompanhar outra estagiária da licenciatura em Artes Cênicas, em uma escola, no período noturno, fui chamada em sala de aula para mediar um problema entre esta aluna/estagiária e os alunos do $2^{\circ}$ ano do ensino médio, na aula de artes. Essa turma tinha mais adultos do que adolescentes, por ser do turno da noite, sendo a reclamação dos alunos no sentido de que eles estavam ali para aprender coisas sérias, não para perder tempo com "teatrinhos".

O desconhecimento e, ao mesmo tempo, preconceito com a área de artes/teatro estão presentes em muitas escolas do país, sendo um dos papeis do professor fazer com que o conhecimento possa vencer esses convencionalismos, que acabam impedindo a ampliação de informações. A negação dos alunos em querer conhecer aquilo que não se conhece, faz parte de toda uma estrutura tradicional de escola e de sociedade alienada, que aceita passivamente as respostas prontas, sem capacidade de elaborar seus próprios critérios de escolha, que, em parte, tem conseguido ser superada, ainda que de forma muito tímida. Depois de muitas tentativas e argumentações improdutivas, resolvi contar uma história para mudar o clima da sala.

Após contar uma história oral, bem cotidiana, do tipo Pedro Malasartes, antes de retomar o debate e encaminhar alguma decisão sobre o estágio da aluna e suas aulas, ouvimos um comentário de uma aluna, como que jogando as palavras ao vento, 'falando por ninguém'. "Até que se fosse pra contar uns casinho assim... até que era bão, né!" Não tive dúvida em aceitar que seria este o trabalho de arte, para aquela turma. Faltava combinar como seriam as pesquisas dos alunos e qual seria 0 papel de cada um, para desenvolverem um conhecimento sobre os contadores de histórias e experimentarem sua arte. Quanto à aluna, sua orientação de estágio, 
mais tarde, continuou no Trabalho de Conclusão de Curso, envolvendo o conhecimento dos contadores de histórias e o ensino de teatro.

A aceitação dos alunos de $2^{\circ}$ ano do ensino médio para trabalhar com os Contadores de Histórias, nas aulas de arte, mais uma vez, foi ao encontro da necessidade que o ser humano tem de ser escutado pelo outro. Ouvir passou a ser mais importante do que contar, no meu ponto de vista de professora, naquele contexto tão solitário, e, simultaneamente, solidário, de uma turma de senhoras, querendo melhorar de vida por meio dos estudos.

As histórias pessoais daquela turma começaram a virar memória. "A memória vai salvando aquelas cenas de nossa vida com as cores do mito e isso passa para o relato oral, tornando-o especialmente valioso" (GIRARDELLO, 2014). Ao dar voz às histórias de vida de cada aluno, o professor está dando uma importância que é imediatamente reconhecida pelos presentes, ou seja, os outros alunos, porque são ouvintes e comungam do conto de quem está no papel do narrador oral.

As histórias pessoais fazem parte da vida cotidiana, construindo a identidade de cada um, ou seja, por meio das histórias de vida de seus alunos, os professores podem conhecê-los melhor, entendendo seus pontos de vista e ampliando perspectivas, por meio de uma formação crítica e autônoma. Dar voz aos alunos e sentidos ao que eles falam significa acreditar neles, respeitá-los, fazendo com que eles se sintam importantes. "O teatro, sobretudo na sala de aula, na contemporaneidade, deve fundamentalmente ser inclusivo e não discriminatório e excludente" (HARTMANN, 2011). É neste sentido que as histórias pessoais dos alunos podem ser ricas, na sala de aula, elas permitem que o aluno se sinta protagonista, convidado, sujeito de seu processo de ensino/aprendizagem. No ensino médio o aluno está em um momento de construção de sua autonomia e competência para a vida adulta, com as responsabilidades que lhe são inerentes.

\subsection{O contador de histórias na formação do professor}

Ao trabalhar com os contadores de histórias, na perspectiva da arte e da educação, alunos e professores são, ao mesmo tempo, ouvintes e contadores, formando uma confusão entre os sujeitos envolvidos, que carece de esclarecimento. 
Minha proposta é mostrar como um contador de histórias se elabora (ou como ele pode se constituir), na contemporaneidade, por meio de cursos, oficinas e experiências individuais e coletivas. Ao se descobrir contador, ele também se constrói como ouvinte, simultaneamente, na medida em que ouvir histórias é um fundamento de sua elaboração. Mas os papeis não se confundem, pois são exercidos em momentos distintos; ora sou contadora, significando o conto junto ao meu ouvinte, ora sou ouvinte, significando junto ao contador as palavras que ele expressa. Para dirimir as dúvidas, esclarecendo os papeis dos sujeitos envolvidos, esclareço que o professor leva a contação de histórias como conteúdo a ser desenvolvido em sala de aula, com base em suas próprias experiências de contador, que continua a ser construída junto aos alunos, na relação educativa de troca e transformação.

Cada professor de teatro, ao escolher trabalhar com a contação de histórias, poderá planejar suas atividades explorando as potencialidades de seus alunos, deixando-os livres para experimentar maneiras diferentes de narração. As orientações podem ser dadas por meio de jogos, exercícios e brincadeiras que, ao fazerem ressonância com pontos das histórias de cada um, passam a ser incorporados na contação. Os jogos teatrais ${ }^{44}$ e os jogos dramáticos se encaixam neste contexto.

Técnicas como: formas animadas, objetos, bonecos, mamulengos, ilustração, sombra, tapetes, cenários, bordados, figurinos, cenários, iluminação, projeções, ambientação sonora, mímica, ou qualquer outra que possa ser associada ou inventada pelo contador, devem ser estimuladas e experimentadas em sala de aula, fazem parte do universo das artes cênicas.

Antes de tudo é preciso perguntar: Que importância têm contar e ouvir histórias, na escola atual? O professor que responder estará pronto a seguir em frente.

As histórias nos ensinam que 'vivemos aprendendo e aprendemos vivendo em um movimento contínuo'. Não costuma ser assim? Quando nós, contadores de

\footnotetext{
${ }^{44}$ Jogos teatrais de autores como: Viola Spolim, Jeam-Pierre Ryngaert; Augusto Boal, e outros, são atualmente utilizados e começam a ser pesquisados por contadores de histórias, a exemplo das publicações nos livros organizador por Benita Prieto e Giuliano Tierno, por exemplo.
} 
histórias, descobrimos o mundo dos contos, quanto mais ouvimos e/ou lemos ${ }^{45}$ histórias, mais descobrimos que temos para conhecer, desvendar, ler, ouvir, sentir. Então, se a escola é lugar de aprender, consequentemente, é lugar para muitas histórias, ou seja, para muitas formas de se contar histórias, desde que seja respeitado aprender livremente com elas. Levando-se em conta que contamos histórias para interagir, compartilhar com os ouvintes, sensibilizar, abrir as comportas do imaginário, atribuir sentidos e significados, descortinar possibilidades de mudanças, em quaisquer direções. Os contadores de histórias têm contribuído, de forma significativa, na construção de novas dinâmicas escolares, por meio de atividades diferenciadas, seja desenvolvendo a oralidade, incentivando a leitura, estimulando a expressividade, variando estéticas, permitindo a criatividade, envolvendo o trabalho coletivo, desenvolvendo a interação, instigando a curiosidade - fator essencial para o ensino/aprendizagem -, organizando pensamentos e tantas mais.

A Prof ${ }^{-} D^{a}$ Vera Titzmann Silva (2008) faz uma crítica aos cursos de pedagogia, sobre a falta de formação dos professores em relação ao incentivo à leitura, nas séries iniciais. Na própria Faculdade de Letras da UFG a disciplina sobre literatura infantil é nova. Ao mesmo tempo, esse gênero cresceu enormemente no Brasil, tendo reconhecimento e lugar em feiras literárias como a Feira de Bolonha e a Feira de Frankfurt, tendo sido país homenageado em ambas, e recebido premiações em importantes concursos. O mais importante deles, considerado pela crítica especializada como Nobel da Literatura infantil e juvenil, prêmio Hans Christian Andersen, já foi, anteriormente, de duas escritoras brasileiras (Lígia Bojunga, em 1982 e Ana Maria Machado, em 2000) e em 2014, foi dado ao primeiro ilustrador brasileiro, Roger Mello. Entretanto, na prática, parece não ter a importância suficiente para fazer parte da formação do professor, a não ser em eventos especiais.

Uma crítica semelhante pode ser feita em relação ao ensino de teatro, nos cursos de Pedagogia, e na mesma direção, da falta de uma disciplina específica sobre contação de histórias, nos cursos de teatro ou qualquer licenciatura, como acontece em outros países como Inglaterra, Argentina, Venezuela e outros. De tal

\footnotetext{
${ }^{45}$ Ler, aqui, pode ter o sentido de compreensão mais amplo, dilatando para leituras diversas de imagem, de mundo, de ponto de vista, enfim, o maior alcance que a couber em nossa compreensão. Leitura pressupõe atribuição de sentidos e significados.
} 
modo, ainda que os contadores de histórias se desenvolvam nas escolas, vencendo resistências de algumas ou de várias formas, considero pertinente a denúncia da falta de formação dos profissionais envolvidos com as crianças, nas atividades de contar e ouvir histórias, que deveriam se fazer presentes nos currículos das licenciaturas. Como defende Andrade, "Contar e ouvir histórias são práticas que devem ser estimuladas em nossa sociedade individualista" (ANDRADE, 2012, p. 127). Por isso, deveriam estar presentes nos currículos daqueles que serão professores.

Porém, ainda que sem nenhuma formação, o professor tem levado a contação de histórias para seu cotidiano nas escolas e contribuído com transformações significativas. A maior contradição da presente tese é justamente admitir que não é necessário um curso de formação de contadores para desenvolver um bom trabalho na área e, ao mesmo tempo, defender minha experiência por meio de cursos de formação, tanto na participação quanto na orientação.

Não se trata de contradição, e sim, de liberdade de construção, com a responsabilidade que lhe é devida. Se todos somos contadores de histórias, todos também podemos ensinar a contar. Nesta perspectiva, aqueles cursos que assumem a investigação e o autoconhecimento de cada um, no processo de escolha e construção de cada narrativa, têm o meu apoio, enquanto sou, também, apoiada por aqueles que, além disso, se dispõe a dividir sua experiência pela escrita.

Portanto, este trabalho não tem a intenção de avaliar, mapear ou verificar a existência ou qualidade dos cursos de formação para contadores de histórias. Entretanto, ao apresentar as reflexões que permeiam o contador de histórias, nas escolas de ensino regular, espero contribuir para que o professor possa, também, refletir sua prática, com base em seus próprios recursos e elementos.

Defendo que o teatro desenvolve uma interação com a plateia, por meio de linguagem verbal/corporal, além de lidar com a alteridade, levando a uma maior possibilidade de compreensão do outro. Ao lidar com uma diversidade de papeis, não só se amplia a visão de mundo, como se tem a possibilidade de experimentar por meio da representação, situações que não caberiam no cotidiano. É, também, com o sentido de alteridade que contador e ouvinte podem construir suas perspectivas e desenvolver sua arte.

Assim, não interessa oferecer fórmulas prontas para o contador de histórias, nas aulas de licenciatura em teatro. Se o professor tiver clareza de sua arte e de seu 
papel, certamente terá condições de realizar um bom trabalho, aproveitando as riquezas dos contadores de histórias, sabendo resguardar as especificidades do seu campo do saber, podendo interdisciplinar com outras áreas do conhecimento. 


\title{
CAPÍTULO 2 - O SUJEITO DA PESQUISA - O CONTADOR DE HISTÓRIAS
}

\author{
Como teria sido, anterior de mil milênios \\ uma outra noite, mais esquecida ainda no silêncio do tempo \\ quando um ancestral mais antigo ainda daqueles primeiros homens \\ descansou sobre os ombros de um menino o peso do braço \\ e entre movimentos das mãos apenas, e do olhar \\ ensinou a ele pela primeira vez um pequeno segredo \\ num tempo em que debaixo das árvores e das estrelas não existiam ainda nem mesmo as \\ palavras, nem mesmo os nomes do mundo? \\ como teria sido o desenho daqueles gestos sem voz \\ e tão humanamente simples que sob a proteção dos astros \\ o homem e o menino adormeceram sem de longe imaginar \\ que haviam feito ali o milagre de aprender-ensinar \\ para que o saber não morra, e nem as pessoas, e nem as estrelas? \\ Carlos Brandão
}

O poema do autor nos leva a entender que, desde o seu início, o ser humano já sentia o desejo e a necessidade de compartilhar com seu semelhante suas descobertas, seus sentimentos e invenções do mundo que conhecia. Pode-se dizer que esse compartilhamento veio se desenvolvendo e constituindo um contador de histórias, que, ao narrar com sua comunidade, movimenta valores que vão se alterando e, ao mesmo tempo, se perpetuando, no dinamismo cultural inerente às formas humanas.

Compreendendo a cultura como uma construção humana em seus significados históricos, portanto, em permanente transformação e ressignificação, por isso, dinâmica, sendo possível observar a existência dos contadores de histórias nas mais diversas civilizações, em tempos e lugares diferentes, sustentando a presença dos valores que cada comunidade acredita e quer cultuar. Desta maneira, ao longo dos tempos, as narrativas serviram às várias sociedades para educar, cultivando valores e ações, criando e recriando os modos de vida existentes na humanidade. A ideia de que os contos têm servido à educação (embora não estritamente a isso), também são identificadas em estudos de várias áreas e épocas, em autores como: Regina Machado (2004a.), Girardello (2004), Gislayne Matos e Ino Sorsy (2009), Cléo Busatto (2006), Benita Prieto (2011), Viviane Rocha (2010) e tantos outros. A coleção dos "Contos da mamãe Gansa", de Charles Perrault, por exemplo, uma das primeiras coletâneas de contos populares, na 
Europa, foi encomendada, na época, pelo rei de França, para fins educacionais, conforme Georgina Martins (1994), traduzidas e publicadas, no Brasil, fez parte do repertório de muitas gerações, com fins análogos. No mundo árabe, a educação familiar é povoada de histórias que dão conselhos, como mostra Malba Tahan ${ }^{46}$, que inspirado nos contos orientais das "Mil e Uma Noites", deixou um vasto repertório de contos publicados. Luís da Câmara Cascudo, um dos maiores folcloristas brasileiros, reconhecido internacionalmente, deixou mais de cinquenta livros e quase o mesmo número de ensaios, que, ainda hoje, influenciam o imaginário de muitas gerações. Atualmente, tanto os contos de ensinamentos de países da África, quanto as lendas e contos indígenas brasileiros, têm sido descobertos, registrados e divulgados pelos contadores, escritores e editores, na contemporaneidade, por diversos fatores.

No poema da epígrafe, Brandão (1985) sugere que a educação brota da troca solidária inventada pelo ser humano, que encontra no contador de histórias além de uma fonte inesgotável de experiências, a possibilidade de continuar algo já iniciado por outro. As invenções humanas foram perpetuadas e continuadas por meio das histórias que passaram de geração em geração.

Essa figura dos contadores de histórias aparece como ação humana, antes de existirem palavras, comprovadas nas inscrições das cavernas, encontradas ainda hoje. Apresentam-se de formas variadas, em diversas culturas, em locais e tempos diferentes, e sobrevivem, hoje, conservando e inovando formas, conteúdos, objetivos e intenções, como é possível observar junto aos autores: Regina Machado (2004a.); Cléo Busatto (2006); Gislayne Matos (2006); Mª de Lourdes Patrini (2005); Giuliano Tierno (2010); Robson Santos (2011); e tantos outros, que escolhi para diálogos de ideias e experiências sobre o tema.

$\mathrm{Na}$ literatura da área, observo anúncios sobre a ameaça de extinção do contador de histórias tradicional, por exemplo, em: Regina Machado (2004a.); Cléo Busatto (2006); Afonso Romano de Sant'Anna (2011); Vivian Rocha (2010). Esta última, em sua tese de doutorado, orientada por Regina Machado, sobre aprendizagem de arte por meio dos contadores de histórias, comenta: "Observei que não era muito fácil encontrar contadores tradicionais. Pesquisando descobri que em

\footnotetext{
${ }^{46}$ MalbaTahan - Júlio César de Mello e Souza, brasileiro, grande contador de histórias, que conheci por meio de minha mãe e de seus livros. Professor de matemática, pesquisador e escritor, que encantado com as histórias árabes acabou adotando este pseudônimo, deixando um vasto repertório de contos escritos, traduzidos e criados, além de um livro específico sobre: "A arte de contar histórias" (1963) e outras publicações bastante populares, como "O Homem que Calculava". Regina Machado (2004a) apresenta um belo estudo sobre esse autor.
} 
muitas partes do mundo, incluindo o Brasil, sobretudo a partir do século $X X$, eles estavam desaparecendo" (ROCHA, 2010, p. 17). Considero o afastamento do contador de histórias decorrente de grandes transformações culturais que ocorrem na história da humanidade. Porém, acredito que a diminuição, constatada pela autora, pode ser considerada uma transformação do contador, decorrente das modificações humanas, portanto, culturais. O próprio fato da existência cada vez mais crescente de pesquisas, com este tema, revela seu fortalecimento no mundo contemporâneo, denunciando movimentos, ainda que tímidos, em vários países.

Isso me leva a averiguar quem são os contadores de histórias de hoje, entendendo, também, que a presença do contador tradicional, mencionado em vários estudos, exige maior aprofundamento. E, para a investigação do sujeito dessa pesquisa, observo, primeiramente, todos os contadores presentes na contemporaneidade, sendo tradicionais ou não, sendo aceita qualquer outra categoria ou alcunha encontrada na literatura, que atenda as demandas aqui suscitadas. Assim, minha primeira observação é no contador que favorece um diálogo presente, ao vivo, sem a dependência de aparelhos eletro/eletrônicos que exigiriam outro tipo de reflexão e pesquisa, não menos importantes. O contador de histórias que se revela no presente, ao vivo, na presença física, no "olho no olho", na comunicação interpessoal $^{47}$, ou seja, naquilo que estou considerando interação com seu ouvinte é o que busco neste estudo.

O fato de deixar claro que tipo de contador interessa a esta investigação, por si só, já comprova a existência de uma variedade entre os narradores que existem hoje. Conhecer essa variedade de narradores, presentes na contemporaneidade, ganha sentido apenas na intenção da delimitação do sujeito a ser investigado.

Embora a investigação alcance uma multiplicidade de áreas, como antropologia, filosofia, história oral, educação e outras, é para a área das artes, ou melhor, do ensino de artes, que direciono a maior parte da experiência. Para que a arte possa fazer parte da educação como necessidade humana, assim como pela contribuição das linguagens artísticas para as performances dos contadores.

\footnotetext{
${ }^{47}$ Como referência de comunicação interpessoal, tomo por base os estudos de Howard Gardner (2000) sobre as Inteligências Múltiplas, entendendo a expressão associada à capacidade de se relacionar e se interagir com outras pessoas. Nesse sentido, é importante deixar claro que a palavra comunicação tem, aqui, apenas o sentido do senso comum, não envolvendo as teorias da comunicação. A perspectiva da presente pesquisa estuda o contador de histórias, no campo das artes, acreditando que esta se efetiva quando contador e ouvinte significam, juntos, o que está sendo narrado, denotando um processo mais interativo do que comunicativo.
} 


\subsection{Primeiras aproximações do sujeito}

Revelar o sujeito da pesquisa significa apresentar as características de um dos contadores de histórias eleito para este estudo. Distingui-lo entre tantos outros sujeitos existentes em sua importância. Trata-se de identificar de qual contador de histórias estaremos tratando, uma vez que no mundo de hoje coabitam contadores de histórias com características semelhantes e diferentes, que atendem objetivos e realidades diversas, que serão identificadas ao longo do texto. Para tanto, esclareço que essas características são dinâmicas, na intenção de afastar possíveis rótulos que aprisionam esses sujeitos, no lugar de libertá-los. Assim, todos que quiserem podem ser contadores de histórias, sendo que, para isto, basta querer e se colocar no exercício do ouvir e do contar. "Afinal, a grande beleza da narração oral está em que cada pessoa conta do seu jeito" (GIRARDELLO, 2004, p. 13). E, este é o encanto do contador que conta com a alma.

Retomando a ideia de que todos podem ser contadores de histórias, reivindico uma formação/descoberta para aqueles que não se sentem aptos a contar uma história. A palavra 'todos' está sendo empregada com o sentido da aceitação das formas diversas de contar histórias, respeitando quereres e limites de cada um, significando, também, quem quiser. Aqueles que querem explorar formas e conteúdos diferentes, a fim de interagir melhor com seu público. A falta de formação reivindicada por esses novos contadores e até por alguns estudiosos, pode ser notada na quantidade de cursos e oficinas para contadores de histórias oferecidos por instituições públicas e/ou privadas. Por outro lado, a procura por algum tipo de formação, observada em minha experiência como educadora, ao longo de mais trinta $\operatorname{anos}^{48}$, em sala de aula, me despertou a vontade de investigar e aprofundar o tema, uma vez que esse contador sempre existiu, como afirmado anteriormente. $O$ problema estabelecido em torno do interesse dessa investigação indica a necessidade de um cuidado, para que o conhecimento sobre o contar histórias possa ser construído, no sentido da descoberta de si, do autoconhecimento, onde

\footnotetext{
${ }^{48}$ Somando os períodos iniciais em que trabalhei sem registro profissional, assumindo salas de aula em jardim de infância e alfabetização, são mais de trinta anos de experiência na escola, em sala de aula.
} 
cada um explora suas possibilidades e quereres, sem a obrigação de "dom ou talento", que pertencem a outro tipo de discussão. Machado (2004a.), Busatto (2006) e Matos\& Sorsy (2009) corroboram com esta ideia de que não é preciso dom ou talento para ser um contador de histórias.

Assim, a formação do contador de histórias, que pretendo contemplar nesta pesquisa, tem como base minha experiência de contadora e formadora (educadora), dialogando com experiências de outros contadores/formadores, a fim de ampliar o máximo possível os estudos da concepção proposta.

Assumo o risco do objeto se misturar ao pesquisador, uma vez que esta investigação tem sua base empírica em minhas experiências pessoais, no que diz respeito à formação do contador de histórias, tanto ministrando cursos e oficinas, quanto desenvolvendo meu próprio repertório e apresentando-o a públicos diversos. Entretanto, considero que a pesquisa em arte envolve experiências e subjetividades que coadunam com o aspecto qualitativo dessa investigação, afastando possíveis estranhamentos por parte daqueles que acreditam em neutralidade da ciência. Algumas das leituras que influenciam meu pensamento e ação em Arte, tanto em seu produto, quanto em situação de ensino/aprendizagem, podem ser encontrados em obras dos autores: Robert Read, Ana Mae Barbosa, Fayga Ostrower, Jonh Dewey, Maria Heloísa Ferraz, Maria F de Rezende e Fusari, João Francisco Duarte, e tantos outros.

Por meio dos cursos e oficinas que ministrei, sobretudo, na disciplina de Núcleo Livre (oferecida aos cursos de graduação da UFG, como integrante dos currículos, frequentada por alunos oriundos de várias áreas), pude observar que o exercício narrativo tem sido pouco estimulado e os diálogos orais presenciais, tem sido cada vez menos concretizada entre os indivíduos. Consequentemente, quem vive mergulhado nas atividades cronometradas e aceleradas do mundo moderno tem poucas oportunidades de convivência com a oralidade, narrativa primeira do ser humano. Esse afastamento da oralidade geralmente aparece nas dificuldades de entendimentos que envolvem fala e audição entre as pessoas, sobretudo quando surge a necessidade de estruturar uma fala mais longa. Walter Benjamin (1975) já denunciava a pobreza de "experiência comunicável" no mundo moderno, na primeira metade do século XX, em seu texto "O narrador", escrito em 1936. "Quando se pede em um grupo que alguém narre alguma coisa, o embaraço se generaliza. É como se estivéssemos privados de uma faculdade que nos parecia segura e inalienável: a 
faculdade de intercambiar experiências" (1975, p. 197/198). É com a intenção de se livrar desse embaraço que muitos alunos procuram essa disciplina, revelando o motivo no primeiro encontro, quando lhes é perguntado porque escolheram a disciplina.

Embora concorde com muitas críticas direcionada aos teóricos da escola de Frankfurt, sobretudo, as interpretações absolutas do pensamento benjaminiano, não posso deixar de reconhecer e concordar com parte das reflexões do autor. Acredito que qualquer professor da escola de ensino básico pode constatar a dificuldade de seus alunos, quando são chamados à frente dos outros colegas, na sala de aula, para alguma apresentação oral, sobretudo, quando envolve o improviso e o uso das palavras. Em outros espaços e na correria do mundo globalizado, o tempo também impede ou dificulta essa exposição pessoal que envolve o ouvir e o contar histórias.

Contudo, percebo que a experiência comunicável, no mundo atual, é cada vez mais facilitada pelas novas tecnologias eletrônicas ${ }^{49}$, alterando o comportamento em analogia ao tempo e a forma de compartilhar suas relações, pela possibilidade das informações imediatas e simultâneas, que passam a ter um alcance ilimitado. Tenho percebido que é comum notarmos pessoas sentadas em volta de uma mesa, ou até em numa rodinha, em uma festa, ou num local de lazer, cada um com seu aparelho nas mãos, interagindo, sabe-se lá com quem, em que parte do mundo, podendo ser, até mesmo, com várias pessoas, em várias partes do planeta, simultaneamente. Isso nos diz que o mundo hoje está cada vez mais rico de experiência comunicável, ao contrário da previsão ou observação de Benjamin. No entanto, a dificuldade observada, anteriormente, reafirma a dificuldade da oralidade, nos levando a entender que, embora o mundo esteja rico em experiências comunicáveis, está mais pobre de comunicações interpessoais, sobretudo, aquelas que envolvem uma linguagem corporal e um estado de presença para o envolvimento da parte de quem ouve. E é essa experiência pessoal na interação oral, por meio da linguagem corporal, que este novo contador procura, hoje, em sua descoberta.

Para identificar quem é o contador de histórias, sujeito desse estudo, é indispensável perceber quem são os contadores de histórias que existem hoje, na contemporaneidade. Desvendar a variedade de narradores da atualidade se impõe

\footnotetext{
${ }^{49}$ Refiro-me às tecnologias da comunicação e informação (TICs) que inclui os usos de aparelhos como: celular, tablet, filmadoras, computadores, internet e afins.
} 
como condição para, em seguida, delimitar mais precisamente o sujeito foco deste estudo.

\subsubsection{O contador de histórias na contemporaneidade}

Somos estória em movimento. Parábolas vivas. E quem conta estórias vive várias vidas numa só.

Afonso Romano de Sant'Anna

Quem é o contador de histórias na contemporaneidade, no Brasil?

Ouço dizer que somos todos nós! São todos aqueles que interagem pelas palavras e vivem no mundo de hoje. Mas, esta afirmação ainda é muito abrangente. Seria possível uma afirmação dessa natureza, sem incorrer em riscos? E aqueles que assumem, deliberadamente, que não conseguem contar uma história cuja dificuldade é visível? Podemos dizer que todos que contam histórias, no mundo de hoje, são contadores de histórias contemporâneos? E quanto às diferenças observadas entre eles?

Todos nós nos interagimos pelas palavras, de alguma forma, e ao ordenar os fatos estamos contando uma história a alguém, por exemplo, contando um sonho, um acontecimento, ou uma ideia. Visto assim, de forma simples, verificamos que em certas ocasiões, no cotidiano, relatamos algo a alguém. O que não deixa de ser uma forma de contar história, descompromissadamente, mais coloquial, utilizando várias linguagens em um diálogo que, muitas vezes, ajuda a construir a narrativa que está sendo contada, improvisada. Nesse sentido, uma conversa pode constituir uma história. Independente da linguagem empregada, ou ainda, da facilidade ou limitação individual de cada um, todos nós compartilhamos histórias, vividas ou inventadas de alguma forma.

Porém, aqueles que têm maior facilidade para relatar os fatos diários são eleitos, naturalmente, como contadores de histórias daquela comunidade, de uma forma mais próxima a uma profissão, embora todos tenham potenciais, podendo desenvolvê-los segundo vontade própria. Assim, todos contam histórias a alguém, com maior ou menor grau de facilidade ou dificuldade, dependendo do interesse e 
das oportunidades de ouvir e narrar. Mas, as formas de contar variam bastante, assim como os locais e objetivos.

No momento em que aparece um público para ouvir essas histórias, pode-se verificar até que ponto a atividade é improvisada, ou exigiu um preparo. Quando acontece de forma organizada, em uma sala de aula, em um palco, na rua ou na presença de um cenário pré-determinado, o contador assume uma condição mais profissional, que exige certa preparação.

$\mathrm{Na}$ atualidade, percebemos a existência de muitas dessas pessoas que assumem a atividade de narrar, advindos de diversas profissões e níveis de estudo, com objetivos e interesses múltiplos, numa infinidade de tipos e recursos.

\begin{abstract}
Vêm vestidas de vermelho, azul e amarelas; fitas penduradas pelo corpo; vêm com jeito de palhaço ou de princesa; outros vestidos de si próprio. Alguns trazem consigo instrumentos sonoros, músicos e cantores; outros são eles próprios músicos e cantores; alguns portam malas, bonecos, fantoches, panos, chapéus, tapetes, bonés, caixa de fósforos, mímica, humor; outros nada trazem, apenas vão chegando, contando, cantando, deixando leitura, múltiplas leituras aos seus ouvidos hipnotizados (BUSATTO, 2006, p. 26).
\end{abstract}

Esses contadores, observados pela autora, encontrados hoje de formas bastante diversificadas, coexistem de maneiras diferentes, embora conservem as características fundamentais da narração oral, com seu poder de suscitar as emoções e imagens do conto, por isso, se revelam como experiência pessoal intransferível.

Com base nessa multiplicidade, percebo o contador de histórias, no mundo contemporâneo, identificando-o em duas vertentes básicas. Em uma delas, encontramos 0 narrador oral cuja experiência advém de sua comunidade, reconhecidamente por seu grupo social, ou por toda a sociedade. Às vezes letrado e, na maioria das vezes, pertencentes a culturas orais, contam suas histórias preservando e difundindo sua cultura, valorizando suas experiências. Ligados à reminiscência, característica fundamental dos narradores orais, são responsáveis por manter e, ao mesmo tempo, produzir novos conhecimentos, para a humanidade. Podemos dizer que, de certa forma, o mundo foi construído com base nas histórias que esses contadores foram contando, recontando, preservando e reconstruindo. $O$ ser humano, ao narrar suas histórias aqui e ali, foi preservando o velho e criando o novo, conforme suas necessidades e vontades, de cada época e lugar. 
Neste primeiro grupo, encontramos o repertório das histórias orais e tradicionais, que se referem tanto aos acontecimentos cotidianos de nossas vidas que viram histórias, quanto aos contos fantásticos, como os contos de fadas e/ou maravilhosos, de assombrações e outros, aprendidos e repassados da boca do avô, para os ouvidos dos netos, fazendo transformar e perpetuar a cultura de cada povo. Esse tipo de contador de histórias não precisa de uma formação sistematizada, ao contrário, oferece ao outro grupo, possibilidades de aprendizagem na apresentação de um conto e no envolvimento com o ouvinte. É como se já nascessem sabendo. Alguém que consegue aprender sozinho, por meio de suas próprias observações, de forma intuitiva. Ao demonstrar facilidade de relatar algo, a própria comunidade, de forma consciente, ou não, o elege como contador de histórias, mesmo que não utilize essa terminologia. Este narrador oral é apontado, hoje, como raro, residente em cidades pequenas do interior ou em fazendas, se diferenciando do outro tipo de contador, encontrado geralmente em centros urbanos maiores, que considero pertencerem ao outro grupo.

No segundo grupo de contadores encontramos o sujeito da nossa pesquisa: 0 contador de histórias que procura, deliberadamente, por uma formação e que coloca seus fazeres a serviço de um determinado objetivo. Não importa o repertório, se conto tradicional, literatura moderna, ou que tipo de recursos vai utilizar em sua narração. É um contador que escolhe deliberadamente, uma história, por algum motivo, embora nem sempre tenha consciência disso, ou seja, atende a alguma inspiração, estudando formas de narrá-la para tipos de público e ouvintes. De qualquer forma, sejam lá quais forem as escolhas desse segundo grupo de contadores, sua característica mais forte é a procura por uma formação e por uma composição artística em seu fazer. É aquele contador que deseja aprimorar seus recursos de interação, por meio da voz e do gesto, expressos pela linguagem corporal. Esse recorte se dá em razão de minha experiência aprendida com os outros contadores e com os alunos que me deram oportunidade de pensar sobre essas questões.

As duas vertentes apontam algumas diferenças, resguardando, também, semelhanças que asseguram um entendimento das várias possibilidades de formas de contadores, sem fronteiras definidas ou exatas. Longe de uma compreensão estanque e rígida, as duas vertentes se misturam, fazendo-nos encontrar contadores do segundo grupo com características do primeiro grupo, e, ainda que mais 
raramente, de forma contrária. Alguns estudos nomeiam este segundo grupo como contadores urbanos.

O contador urbano é aquele que, inserido em uma comunidade de tradição escrita, é portador de um repertório de histórias ancestrais e literárias, memorizadas e aprendidas principalmente pela leitura, pois ocasionalmente aprende pela oralidade. Ele transforma o conto e a narração em uma apresentação artística, o que pressupõe uma situação de apropriação e criação pessoal, fruto de aprendizagens geralmente adquiridas em oficinas e cursos de formação de contadores (ROCHA, 2010, p. 109).

Embora esses contadores, em todo seu conceito, pertençam ao segundo grupo de minha descrição, continuo não assumindo uma nomenclatura única em meus estudos, pelas variações que carregam, mas devo reconhecer as semelhanças com o contador urbano, identificado por Vivian Rocha.

Não obstante esses dois grupos de contadores sejam contemporâneos, o contador de histórias que investigo é aquele cuja aprendizagem é adquirida por meio de estudos, por vontade própria, respeitando a diversidade de objetivos e formas, investigando o universo de elementos que podem compor a forma de linguagem de cada conto. Ao considerar as experiências de outros contadores de histórias, comparadas com minha própria vivência, o debate pode ser ampliado, orientando discussões e reflexões acerca dessa construção. Longe de sistematizar ou apontar modelos para a construção de um contador de histórias, persigo as várias possibilidades que se abrem para um contador atual e a responsabilidade na escolha dos caminhos.

Ao buscar vozes de outros contadores, abrindo diálogo com minha experiência pessoal, na direção da investigação de como se dá a constituição do contador de histórias, acredito contribuir para desmistificar possíveis mitos construídos em torno do tema, sobretudo, acusando o uso de algum recurso como certo ou errado. Ao considerar o ato de contar histórias como atividade artística torna-se pressuposta a inexistência de regras fixas e/ou erros e acertos, independente de qualquer contexto de sua produção. "Contar histórias é uma arte muito antiga, presente em diferentes culturas e que se mantém viva na contemporaneidade pela voz dos artistas da palavra" (ROCHA, 2010, p. 53). O que combina e se encaixa perfeitamente em uma história, pode não combinar em outra. Portanto, a base de nossa investigação está em aceitar a diversidade de alternativas, propósitos e caminhos escolhidos por cada um que quer se tornar um 
narrador oral. Consequentemente, é um estudo que pretende mostrar a impossibilidade de considerar modelos prontos ou indicações determiantes.

Alguns contadores daquele segundo grupo estão presentes nas escolas brasileiras, ainda que de forma tímida e insuficiente, do meu ponto de vista, pelos benefícios que poderiam trazer no cotidiano escolar. O inglês Geoff Fox (1999), em uma temporada na Universidade Federal de Santa Catarina - UFSC ${ }^{50}$, explica que, em seu país, todo professor é considerado, naturalmente, um contador de histórias, justificando sua afirmação pela atenção dada aos currículos a este respeito. $\mathrm{Na}$ Inglaterra, segundo o autor, todos os currículos de licenciatura possuem três disciplinas obrigatórias: Literatura infanto-juvenil, Arte dramática e Contador de histórias (FOX e GIRARDELLO, 1999). Essa riqueza na construção do currículo demonstra a importância dada ao campo das artes, fato justificado em terra de Shakespeare.

A arte de contar histórias, segundo minha experiência pessoal, pede alguma preparação, por mais aberta que seja. Pelo menos, uma pesquisa que envolva uma estética em busca de emoções e imagens que o contador suscita em seu público ouvinte e uma visão crítica para reconhecer as consequências de suas ações. Neste sentido, acuso a quase inexistência dessa formação nos cursos de graduação, sobretudo, nas licenciaturas, que continuam a formar professores com ideias de décadas e contextos passados. São poucos os projetos nessa área, que por sua importância e resultados mostram necessidade de ampliação e manutenção. Podemos citar alguns profissionais que, desde o princípio de seus projetos, têm contribuído com a ampliação e formação de uma rede de contadores no Brasil: o grupo Morandubetá, nas figuras de Benita Prieto, Eliana Yunes, Celso Sisto e Lúcia Fidalgo, no Rio de Janeiro; Regina Machado, em São Paulo; Gilka Girardello, em Santa Catarina; Gislayne Matos, em Minas Gerais; falando apenas os mais próximos da minha experiência. As obras desses autores são debatidas, ao longo da tese, por serem alguns dos eleitos para os diálogos sobre as experiências do contar histórias.

Embora esses nomes e projetos sejam desenvolvidos em instituições do ensino superior e sejam extremamente importantes, nem de longe atendem a demanda necessária e requerida para a formação de um professor-contador de

\footnotetext{
${ }^{50}$ Intercâmbio entre a UFSC e a Universidade de Exeter, na Grã Bretanha, com apoio financeiro de ambas as partes, cuja produção resultou na publicação de uma revista com vários artigos, organizada por Beatriz Cabral em 1999, com participação, também, de Gilka Girardello, que escreve um artigo em conjunto com Geoff Fox.
} 
histórias, nem no campo das Artes, e nem em nenhuma outra área. Ainda que possam manter acesso a um movimento em torno do tema, não garantem que a maioria dos professores considere a importância de saber ouvir e saber contar, nas relações educativas ${ }^{51}$ com seus alunos, por exemplo. Por isso, esse trabalho é mais uma pequena contribuição, na esperança de que os ditos populares possam funcionar um dia: "De grão em grão a galinha enche o papo"; "A educação se faz a passo de formiguinha... ela é capaz de mover montanhas";

O exame mais detido, em cada um dos dois grupos apontados, poderá esclarecer quem são os contadores de histórias, na contemporaneidade, e quais são suas contribuições, para, enfim, chegar à delimitação e esclarecimento sobre o sujeito dessa pesquisa.

\section{a) O contador de histórias tradicional}

O contador de histórias é atemporal e tudo começou assim, ao redor do fogo, como estamos agora, sentados sentindo o calor das chamas e a ansiedade da alma para que a história comece logo.

Robson Santos

Com o reconhecimento da existência de tantos tipos de contadores de histórias, todos eles convivendo na contemporaneidade porque coexistem no tempo de hoje, quem pode ser considerado como contador tradicional? Ao tratar dessa questão, reconheço que há, sim, diferenças entre os contadores tradicionais e os contadores que procuram por uma formação, uma investigação nas formas de se apresentar e contar, assim como há, também, semelhanças que impedem uma classificação ou divisão exata ou rígida de cada tipo de narrador oral. Entretanto, algumas características podem ajudar a entender quem é, ou quem mais se aproxima do contador tradicional, apontados, anteriormente, como primeiro grupo,

\footnotetext{
${ }^{51}$ Com experiência de 32 anos em sala de aula, portanto, participando de várias mudanças na sociedade, entendo que a postura de um professor, hoje, é diferente do 'repassador de informações' para o qual fui formada. Se os alunos têm até maior acesso a informações variadas que os professores, estes últimos passam à uma condição de organizadores do pensamento e da visão crítica dos temas em estudo, exigindo que ambos saibam ouvir, isto significa diálogo, também exploradas nas ideias de Paulo Freire e tantos outros educadores, como Ruben Alves e Augusto Boal. Mas, a realidade que encontramos, sobretudo nas escolas públicas, continua mostrando professores tradicionalistas, que abusam da cópia de conteúdo no quadro giz, com carteiras enfileiradas como em um quartel militar, sem grandes vontades de mudanças ou transformações.
} 
ou primeira vertente entre os contadores contemporâneos. Nos estudos de Rocha (2010), por exemplo, é possível verificar que o tipo de repertório pode ser um caminho de reconhecimento desse tipo de contador, uma vez que a autora considera como tradicional quem narra oralmente, com suas próprias palavras, diferente daqueles que leem, ou recitam textos memorizados. É nesse sentido que ela se refere ao contador "genuíno" ou "original".

Contudo, a palavra genuína me parece um tanto forte, pois ao considerar que o contador sempre existiu, então teria de aceitar como genuíno o contador do tempo das cavernas, ou aquele contador pertencente ao imaginário de uma geração passada, como tradicional. E não é bem assim, cada contador é por si só genuíno, porque sua experiência é única e ele a compartilha com seu ouvinte, enquanto narra. Como é dito no senso comum: "nenhuma água banha a mesma margem, mais de uma vez" e, "ninguém é o mesmo depois de ouvir ou contar uma história", ainda que repetidas vezes.

Identifico, ainda, vários narradores orais da atualidade que preferem um repertório de contos tradicionais e orais, sem assumirem a condição de narrador tradicional.

Entendo o termo 'original' utilizado pela autora, como 'de origem', portanto, aquele contador que aprendeu seu ofício em sua cultura, em sua comunidade, de forma intuitiva e repetitiva, tradicionalmente, como observado em tantos estudos antropológicos que descrevem diferentes sociedades. Da mesma forma, considero o termo 'genuíno' como uma opção um tanto perigosa, uma vez que, em algumas situações, é muito difícil separar certos tipos de contadores, pois depende do contexto envolvendo fatores imprevisíveis. É certo que esse contador conta com o improviso, embora essa característica não possa ser exclusiva de um tipo apenas de narrador oral, pertencendo à maioria deles.

A dificuldade de classificar tipos de contadores pode ser exemplificada com Gislayne Matos, cujo repertório se direciona para os contos tradicionais, embora sua atuação alcance grandes centros urbanos e institucionais. Sua aprendizagem inicial foi em família, com seu avô, conta ela em entrevista, na tese de doutorado de Viviane Rocha (2010, p. 35/36), portanto tradicional. Entretanto, seus estudos são reconhecidamente acadêmicos, caracterizando-a como pertencente ao outro grupo de contadores, aqueles que assumem uma formação, seja como multiplicadora ou como contadora, podendo ser reconhecida, também, como contadora urbana. 
Embora com o repertório do primeiro grupo, pertenceria mais ao segundo grupo, confirmando as fragilidades de uma classificação.

Regina Machado é outro exemplo de uma estudiosa da atualidade que demonstra preferência pessoal pelos contos orais, sobretudo, os contos tradicionais, de várias culturas diferentes, revelado em seus estudos e projetos conquanto seja uma pessoa que se relaciona com todos os tipos de contadores e ouvintes, respeitando a forma de cada um. Atuando na formação de muitos contadores, em São Paulo e outras localidades, ela demonstra abertura no contato com o universo dos múltiplos contadores contemporâneos, contribuindo para sua valorização.

Mais importante do que ficar classificando quem pertence a um ou outro grupo é entender a extensão e os significados desses tipos de contadores, para encontrar seu próprio caminho, que não precisa ser igual ao de ninguém. Tradicional ou não, todos os tipos de contadores têm seu lugar na atualidade.

O tratamento dado ao contador tradicional explicita as linhas teóricas assumidas, que revelam ao leitor orientações para a compreensão de que não há uma separação exata ou contornos acabados, em qualquer dos tipos de contadores. Suas características se interpenetram, produzindo semelhanças e diferenças que deixam suas fronteiras móveis e inexatas, ou híbridas, como nomeiam alguns teóricos. Assim, corroboro com Vivian Rocha em sua definição de contador ou narrador tradicional, embora com a ressalva já feita em relação ao uso dos termos 'original' e 'genuíno':

O contador ou narrador tradicional é o portador de um repertório de histórias
ancestrais, conhecidas, memorizadas e aprendidas pela oralidade no seio
da comunidade a qual pertence, e que narra numa situação performática,
que pressupõe uma situação de apropriação e criação pessoal do contador,
ao mesmo tempo em que um conteúdo ancestral é transmitido e um
patrimônio cultural é preservado. O narrador tradicional pode ser chamado
de narrador ancestral, narrador habitual ou ainda narrador de raiz. Todas
essas expressões são adequadas porque se referem a um contador original
e genuíno, pertencente a uma corrente de transmissão de um patrimônio
cultural (ROCHA, 2010, p. 53/54) grifos meus.

Nesse sentido, ainda é possível reconhecer contadores de histórias tradicionais, em algumas regiões do mundo e do Brasil, apresentados pela autora em: "conversas ao pé do fogo", onde são estudados contos e contadores da tradição oral. Também, em outras pesquisas utilizadas nesta tese, como os contadores de 
fronteira, de Luciana Hartmann; os contadores da folia do Divino, na pesquisa de Graça Veloso e os contadores de Pirenópolis, na pesquisa por mim coordenada.

Esses contadores tradicionais, do ponto de vista da minha seleção, são aqueles cujos saberes populares tem origem nas observações cotidianas, diferentes dos que já frequentaram uma academia e misturaram seus conhecimentos e vivências a estudos científicos e experimentos já sistematizados. Percebo que, mesmo entre os contadores tradicionais, há diferenças significativas entre os vários tipos de localidades, na forma, conteúdo e objetivos. Assim como são diferentes os enfoques dos pesquisadores que envolvem o contador de história.

Como exemplo, trago a pesquisa de Graça Veloso (2009) sobre a folia do Divino Espírito Santo, em Luziânia, cidade do entorno de Brasília, no interior do Estado de Goiás. Em sua investigação, os contadores de histórias são percebidos pelo pesquisador dentro da festa, mais especificamente, nos pouso de folia, momento em que todos estão mais descontraídos, conversando. O intuito do pesquisador foi recolher material para cena, fornecida pela espetacularidade dos contadores de dentro da folia do Divino, tendo a etnocenologia como metodologia de estudos. O resultado é apresentado no monólogo intitulado "Inderna de Intão", onde Dona Luzia dialoga com vários personagens imaginários de seu passado, os bois, o marido e Futrica, o cachorrinho. O enfoque da pesquisa dirigiu olhares para futuros materiais de cena. Pelo olhar do pesquisador, percebo que o contador de histórias apareceu como personagem presente na festa de folia, não que estivesse, deliberadamente, sendo procurado. Porém, chamou atenção e participou, com importância significativa, dos resultados da pesquisa de Graça Veloso.

Outro exemplo é a pesquisa com as 'narrativas de fronteira' entre Brasil, Argentina e Uruguai, que envolvem contadores tradicionais, desenvolvida por Luciana Hartmann, apoiada pela Antropologia, com olhares das Artes Cênicas, mais especificamente, na área da performance. Com abordagens sobre as performances narrativas e seus conteúdos, a pesquisa revela os personagens da fronteira com seu modo de vida, suas peculiaridades, tradições e relações sociais. A pesquisadora descobriu que para além do 'Galpão', com a fogueira e os contadores tradicionais, existia uma rede de contadores, que envolvidos no cotidiano, enredam os personagens que Ihes pertencem, apresentando os modos de vida daquela região, conhecida por tríplice fronteira. "Mais do que especular as diferenças e semelhanças entre as tradições orais dos três países, investigar essas relações de fronteira 
através das narrativas e de suas performances" (HARTMANN, 2011, 25), foi o maior foco dessa pesquisa, afirma a autora.

$\mathrm{Na}$ opção de conhecer mais de perto esses contadores tradicionais, a outra pesquisa que apresento foi coordenada por mim, envolvendo contadores tradicionais de Pirenópolis - "Os contos do Arco da Véia" -, desenvolvida na UFG, com vários subprojetos, durante os últimos doze anos, com várias interrupções, reiniciada, sempre, por alunos da graduação. Embora os três exemplos escolhidos tenham no sujeito o contador de histórias tradicional, os focos, perspectivas e objetivos são diferentes, enriquecendo o conhecimento sobre um sujeito que suporta múltiplos olhares, sem perder sua essência.

\section{*Contos do Arco da Véia- pesquisa em Pirenópolis}

Diferente das posturas dos contadores pesquisados por Veloso e Hartmann, o contador de histórias pesquisado por mim na cidade de Pirenópolis - Goiás, se assumia como tal e também era apontado pelo próprio pessoal da cidade como contador de histórias, que nunca deixava de ter uma plateia, mesmo que fosse somente em festas, para amigos e vizinhos. No entanto, reconheço como contadores tradicionais, ou contadores de raiz, os tipos referidos acima, nas pesquisas de Veloso e Hartmann, assim como os participantes da pesquisa "Contos do Arco da Véia", com os contadores de Pirenópolis, que passo a relatar.

Primeiro, conheci Dona Benta, no início, ouvindo falar do famoso Seu Ico, companheiro de tantas aventuras com Dona Benta e Marieta. São moradores da cidade, desde o nascimento, considerados pelos residentes do bairro do Carmo e frequentadores da paróquia, reconhecidos como contadores de histórias, sendo chamados para este fim, por muitos anos, para programações festivas, como me relatavam os moradores, em conversas informais, quando ficavam sabendo que eu era contadora de histórias.

Dona Benta tinha uma maneira bem peculiar de iniciar suas apresentações, dialogando com a plateia, antes de anunciar e iniciar uma história. Apresentava-se com um texto praticamente decorado "Tô com 76 anos, sou de 23, nasci aos domingo, às nove hora do dia. Meu nome é conhecido por santa, na missa de São Bento. Então, pra num ficar só Benta, põe Verônica, né, ah, ah. Benta Verônica de 
Barros, né?" Depois iniciava uma curta sessão de adivinhas e charadas ${ }^{52}$. Cantava uma música de sua autoria, cuja rica experiência será relatada, oportunamente, tocava um instrumento feito por ela própria $^{53}$, sempre que podia anunciava a distribuição de biscoitos ('peta'54, que ela mesma fazia). Falava em uma "língua do B", desafiando quem conseguisse entender e traduzir o que ela dizia. Depois de todo esse ritual, vinham as histórias e ela sempre perguntava se dava tempo das pessoas ouvirem. Queria saber qual história contar, de acordo com o tempo que teria disponível, revelando um profundo conhecimento sobre as relações do tempo entre as pessoas do mundo atual.

Essa dimensão acompanhou cada momento da pesquisa, os choques de tempo e contratempos revelavam as diversas formas, leitura e maneiras de lidar com essas questões. Considero que essa observação foi possível pela característica fundamental da pesquisa, que sempre recolheu as histórias em sessões públicas promovidas pelos integrantes do grupo, em locais variados, procurando alcançar o máximo de ouvintes possível, em cada ambiente. A diferença de ritmo é mesmo marcante entre capital e interior, por razões que não preciso descrever. O admirável é o nível de consciência, sabedoria e percepção de uma narradora oral que conhece seu público, só de olhar para ele, mesmo sem frequentar os centros urbanos maiores e recebendo esse tipo de público.

O repertório de histórias de Dona Benta varia entre contos de príncipes e princesas e histórias de peraltices, como as narrativas de Pedro Malasartes. Embora dissesse que não sabia escrever, empurrando a tarefa, sempre que precisava, para Marieta (a outra contadora), sabia desenhar os números para fazer os 'adivinhas' de matemática. Também tinha, em sua casa, uma caderneta onde fazia anotações particulares.

\footnotetext{
${ }^{52}$ As charadas de Dona Benta lembraram minha infância, em casa, na hora do almoço. Sempre tínhamos uma brincadeira e nunca havia conhecido ninguém que fizesse aquele tipo de charada. Exemplo de uma inventada na minha casa: "O oceano na cintura, é meu irmão". 1 e 1. E, a maneira de resolver: os números significam a quantidade de sílabas que é dada pelos enigmas, na primeira e segunda parte da frase. O resultado deverá ser uma palavra de 2 sílabas no exemplo citado (indicados pelos números: 1 e 1), correspondendo ao significado da última parte da frase. Então: oceano=mar; na cintura=cós; meu irmão = Marcos! Outro exemplo, de D. Benta: "Aqui, esse biscoito está no inferno" - 1 e 2. Resposta: aqui = ca (1 sílaba); esse biscoito = peta (2 sílabas); está no inferno $($ resposta final $)=$ capeta.

${ }^{53} \mathrm{O}$ som deste instrumento (tipo gaita de boca) era produzido pela passagem do som entoado por ela, que alteravam a frequência com a vibração do plástico no pente, que amarrava à ponta de uma cabaça utilizada como caixa de ressonância.

${ }^{54}$ Biscoito de polvilho assado, bastante conhecido na região. É o mesmo vendido nas praias do Rio de Janeiro.
} 
Em algumas de suas histórias, percebemos trechos de outras, revelando a existência de uma rede de histórias que povoam o mundo. Por exemplo: "O causo da linguiça", do repertório ${ }^{55}$ de $D$. Benta, se parece muito com um conto de Nashudim $^{56}$, contado pela francesa Oro Anahori-Librowicz ${ }^{57}$, no encontro Boca do Céu, em São Paulo, 2012. Comparando as duas versões percebo que os personagens e objetos são outros, mas a estrutura e conteúdo continuam os mesmos. Em outra história, "Joãozinho Adivinhão ${ }^{58 ", ~ v a ́ r i a s ~ p a s s a g e n s ~ d e ~ c o n t o s ~}$ europeus (dos irmãos Grimm e de Charles Perrault) são perceptíveis. Isto mostra que, mesmo que a contadora não soubesse ler, certamente teve contato com alguém que leu para ela, ou aprendeu a história em um livro, repassando-a oralmente, revelando que a separação entre conto oral e literário é recente e, não necessariamente, determinante. Portanto, um repertório de contos orais pode estar impregnado e/ou misturado de registros e contos literários, reafirmando, mais uma vez, a ineficiência das teorias classificatórias nesta área.

Já Seu Ico era o contador de histórias mais famoso e reconhecido da cidade. Homem sábio, de grandes conhecimentos sobre as plantas e remédios do cerrado, um conselheiro da comunidade pirenopolina. $\mathrm{Na}$ época da pesquisa, já estava aposentado como porteiro da escola, preservando a função de sineiro da igreja Matriz. Quando reaparecemos na escola promovendo um reencontro, foi emocionante para todos: professores, Seu Ico, nós, os alunos novos que se deliciavam e os antigos, que matavam a saudade de suas histórias. Presenciei relatos emocionados e saudosos do tempo que sempre contava histórias para a criançada.

Difícil falar de Seu Ico, por tamanha grandeza e simplicidade em uma só pessoa. A riqueza de seu conhecimento chegava a ser comovente em tudo o que fazia parte da vida na região. Escreveu uma peça teatral, em 3 atos, (apresentada

\footnotetext{
${ }^{55} \mathrm{O}$ repertório das histórias recolhidas nesta pesquisa fará parte do anexo 2 da tese.

${ }^{56}$ Que minha mãe diz ter ouvido em sua infância, embora não tenha conseguido encontrar referências.

57"Oro Anahory-Librowicz é apaixonada por todas as formas da tradição oral. Especialista das canções tradicionais judeu-espanholas, ou latinas, ensina espanhol na Universidade de Montreal. Oro semeia seus contos aos quatro ventos, em francês, inglês, judeu-espanhol e em espanhol, sua língua materna. Já fez apresentações no Canadá, nos Estados Unidos, na Inglaterra, na Espanha e na Venezuela. Contar é sua maneira de partilhar com o Outro seu próprio patrimônio e sua humanidade. É também a forma que ela encontrou de suspender o tempo, triunfar sobre o cotidiano e tocar o encantamento da vida". Consultado em:http://bocadoceu.com.br/edicoes-anteriores/boca-do-ceu2012/convidados-internacionais/, em 14 de maio de 2014.

${ }^{58}$ Pode ser encontrada no anexo 2 dos "Contos do Arco da Véia".
} 
no teatro de Pirenópolis, por esta época da pesquisa) e participou de documentários de diferentes naturezas ${ }^{59}$. Seu repertório de histórias era mais infantil, embora ao dirigir a palavra ao adulto sempre tivesse algo importante a dizer. Uma vez, Isabela Rovo (cantora e contadora de histórias) contou "O causo do espelho"60" (registrado por Ricardo Azevedo), e ele disse com uma risada: "Mas minha filha, só isso de personagem? Tem muito mais!" Não tivemos tempo de conhecer a versão dele. Às vezes me pego reinventando esses personagens, encompridando a história. Quais seriam?

Dona Benta e Seu Ico já se foram de nossa companhia, deixando saudades e um belo repertório de histórias inéditas, que nunca vi registradas ${ }^{61}$ ou contadas, em lugar algum. Continuam, na cidade, os outros contadores que fizeram parte da pesquisa: Marieta, Safia e Seu Bertoldo.

Marieta é uma pessoa encantadora, poetiza, amiga e vizinha de Dona Benta, na época da pesquisa. Estava sempre por perto. No início, para acompanhar Dona Benta, até que um dia eu pedi a ela que contasse uma história. Pronto! Estava ali mais uma contadora de histórias e poetiza, que veio a ser integrante da academia pirenopolina de letras, na qual tive o orgulho e a honra de ter feito parte dessa aproximação.

Uma das histórias preferidas de Marieta, "Missa dos mortos", encontra-se na coletânea de contos de Câmara Cascudo (2002), mostrando, mais uma vez, que contadores tradicionais podem ou não utilizar de um repertório já escrito. Outras histórias de seu repertório revelam mais de perto sua cultura e costumes cotidianos, tendendo a finais moralizantes, para educar, segundo crenças e costumes de seu tempo.

Safia, que tem o apelido advindo da contração de "sua filha", é também santeira, criando peças em barro (santos, e também personagens e cenários de

\footnotetext{
${ }^{59} \mathrm{Na}$ COEPI - Cooperativa Educacional de Pirenópolis (fundada e doada pela Associação dos Amigos de Pirenópolis), existe um acervo de participações de S. Ico em filmagens, editadas, publicadas e documentos a serem inventariados.

${ }^{60} \mathrm{Um}$ marido, em viajem, compra uma novidade (um espelho) pensando ser a fotografia de seu falecido pai; chegando em casa, guarda no fundo da gaveta. A esposa vai olhar escondido e pensa que o marido arranjou uma amante; a mãe tenta acalmar a filha dizendo que aquela velha horrorosa da foto (se olhando no espelho) já estava com o pé na cova... e assim continua, ou melhor continuaria com S. Ico aumentando a confusão com o número de ações.

${ }^{61}$ Durante vários anos, trabalhamos esse material em grupos de pesquisa com alunos da UFG, do curso de Artes Cênicas e outros cursos, e contando histórias para diversos públicos, em todo o Brasil, nunca encontrei as versões das histórias que recolhemos, nesta pesquisa. Encontramos pontos de contato, semelhanças e coincidências, mas, na íntegra, as histórias são diferentes, mostrando traços peculiares da cultura local.
} 
suas histórias) e contadora de histórias. Safia ganhou esse apelido pelos vizinhos que sempre tinham uma reclamação para sua mãe: "Oh vizinha, olha sua filha subindo no telhado..." - mas na oralidade o som era outro: "Oh vizinha, óia safia in riba do teiado...". "Safia rasgo a rôpa no arame". Safia isso, Safia aquilo, ninguém a conhece por outro nome. A maior quantidade de histórias ${ }^{62}$ recolhidas nessa pesquisa é dela, e do meu ponto de vista, também são as mais desconhecidas e inusitadas, sem falar na riqueza das figuras de linguagem apresentadas.

Por fim, Seu Bertoldo foi o quinto contador que participou de nossa pesquisa, embora em poucos momentos, incentivado por uma das integrantes da pesquisa na época, que era sua filha e professora numa escola pública da cidade. Sua contribuição com a história "Bate meus dois pauzinho", rendeu um conto literário e uma peça teatral, escritos por dois atores, ex-alunos do curso de artes cênicas da UFG, no ano de 2007.

Os temas das histórias, como um todo, em sua maioria, são assuntos do cotidiano, que revelam o modo de vida peculiar do povo daquela cidade e região. No entanto, há narrativas que misturam trechos de contos de fadas ou contos populares, já registrados, anteriormente, revelando a influência de uma rede de histórias tecida pela oralidade. Na divisão por temas encontramos histórias de: casamento, bobeira, diabo, assombração, padres, coisas da roça. Contos aparentemente inéditos, nunca encontrados por mim, em apresentações por vários cantos do país, revelam o modo simples de ser do goiano. Outros revelam traços de intertextualidade com contos de fadas e contos populares já publicados. Variações nos gêneros narrativos, com histórias circulares, cumulativas e contos de estrutura tradicional, também foram verificadas no repertório da pesquisa.

Dentre os cinco contadores de histórias que participaram desses eventos restam, hoje, Safia e Marieta. Os projetos têm aparecido em menor número, sobretudo, se relacionados com a época em que foi realizada a Ação Griô, em seu primeiro edital. Outros contadores tradicionais foram descobertos pelo Ponto de Cultura Guaimbê, que continua desenvolvendo trabalhos com a oralidade, em outras direções, na cidade de Pirenópolis.

\footnotetext{
${ }^{62} \mathrm{O}$ anexo 2 que contém as histórias da pesquisa estão identificados pelo nome dos contadores.
} 


\title{
b) $O$ contador em construção
}

\begin{abstract}
O contador é o responsável pelo estabelecimento das relações lúdicas e amorosas entre a palavra e a escuta, entre o narrador e $o$ ouvinte, entre a oralidade e a escrita e entre o leitor e o livro, esboços

de um repertório cultural. Ma de Lourdes Patrini
\end{abstract}

Diferente do contador tradicional, que aprendeu a contar histórias sem formalidades, inserido em seu contexto de narração, existe, hoje, outro tipo de contador de histórias que procura por uma formação, uma aprendizagem específica. O fato de haver tanto uma procura quanto uma oferta de cursos de formação para contadores de histórias, em vários níveis e diversas abordagens e durações, comprova a existência desse outro tipo de contador, que, nem sempre, tem a oportunidade de um contato pessoal com o contador tradicional. Os cursos e oficinas, que se multiplicam a olhos vistos, podem ser confirmados e encontrados em uma busca simples na internet, identificando eventos e iniciativas menos ou mais isoladas, locais, regionais e internacionais.

Hoje, encontramos uma multiplicidade de contadores de histórias com atuações diversas, formações variadas e práticas diferentes. Nesse sentido, minha experiência não é única, pelo contrário, encontra ressonância com os contadores que transitam nessa direção, em tantos eventos, escolas, bibliotecas e ONGs, que oferecem e constroem projetos que envolvem, de alguma forma, os contadores de histórias. Estes parceiros se fazem presentes ao longo dessa escrita, fortalecendo as reflexões no diálogo com a experiência de contar e de formar contadores.

Os contadores de histórias pertencentes ao segundo grupo, anteriormente apresentado, também oferecem uma diversidade e amplitude em seus fazeres, que a presente investigação não pode dar conta de abarcar. Por isso, a análise de experimentos, vivências e diálogos com outros contadores, por meio de minha experiência como contadora e formadora, constituem o cerne dessa pesquisa, mostrando uma das possibilidades de construção do contador na contemporaneidade.

Assim, como esta pesquisa não tem a intenção de criar rótulos e classificações para os contadores, na contemporaneidade, também tem o cuidado 
de não desmerecer nenhuma intenção direcionada a tal atividade, e, muito menos, de eleger melhores ou piores trabalhos, ou menos e mais importantes. Nesse sentido, os escolhidos para as reflexões, aqui apresentadas, o são pelos encontros nas experiências que suscitam o diálogo para aprendizagem por meio da troca de vivências.

Com essas ressalvas, passo a analisar alguns estudos que considero mais próximos de minha experiência, na intenção de exemplificar e identificar o sujeito contador de histórias, escolhido para essa investigação.

Esse contador que se constrói no mundo de hoje, diferente do contador tradicional, não é novidade apenas no Brasil. Na França, por exemplo, foi identificado e estudado por Patrini ${ }^{63}(2005)$ em um movimento que ela chama de "Reconto", nas três ultimas décadas do século XX, que considero ter origem análoga aos contadores de histórias do Brasil, resguardadas as devidas diferenças de época e contexto, é claro. Para Gislayne Matos, os contos e contadores de histórias reaparecem no cenário urbano como num movimento. "Poderíamos localizar esse 'fenômeno de sociedade' entre as décadas de 1970 e 1980, na Europa, nos Estados Unidos e no Canadá, e entre 1980 e 1990, no Brasil e nos demais países da América Latina" (MATOS, 2012, p. 112). Corroborando com Patrini e Matos, para Carles Garcia o primeiro movimento de contadores, na Europa, se deu no princípio da modernidade, com os primeiros registros dos contos orais, mas reconhece, na atualidade, a recuperação dos contadores em fase de extinção.

Foi na França, na Escócia e na Itália que se iniciou o processo de recuperação da narração como profissão ou pelo menos como prática comum, com surgimento dos primeiros narradores habituais (não profissionais). No final de 1970, esse interesse se estendeu para os países da Europa Central e para os países Nórdicos. No início dos anos 1980, esse avivamento chegou aos países do Mediterrâneo (GARCIA, 2012, p. 318).

Ao considerar o caráter ritualístico que envolve o contar histórias, afirmamos sua presença nas diversas culturas humanas, ao longo dos tempos, considerando as várias formas com que se oferecem. Isto leva ao entendimento e à observação das várias formas com que cada cultura trata seus contadores de histórias, apontando o quase desaparecimento dos contadores no ocidente, sobretudo, nas sociedades urbano/industriais, e sua conseguinte retomada, de formas diversas,

\footnotetext{
${ }^{63}$ Mariade Lourdes Patrini. Tese de doutorado em Antropologia Social, na École des Hautes Études, em Paris, com o título: Les conteurs se racontent. Defendida em 1998, publicada em 2002.
} 
porém, com muitos pontos de contato. Assim, passo a analisar os pontos de encontro entre os movimentos recentes de contadores de histórias, na França, por meio da pesquisa de Patrini (2005) e de minha experiência pessoal com movimento no Brasil.

$M^{a}$ de Lourdes Patrini (2005) reconhece um movimento atual dos contadores de histórias, sobretudo, nos grandes centros urbanos, nascido nas bibliotecas, analisado em sua obra: "A renovação do conto: emergência de uma prática oral". O estudo analisa as sociedades francesas, no final do século $X X$, portanto, mesma época em que iniciaram as atividades do Proler ${ }^{64}$, no Brasil. $\mathrm{Na}$ época, Afonso Romano de Sant'Anna estava à frente da Fundação Biblioteca Nacional, sendo um dos responsáveis pelo inicio do programa.

A contação de estórias passou a ser revalorizada de maneira notável nas últimas décadas, sobretudo a partir dos anos 1980. Uma diversificada bibliografia que permeia diversos ramos do conhecimento nos dá conta de uma verdadeira redescoberta da arte de contar histórias (SANT'ANA, 2011, $p$, 14) grifos meus ${ }^{65}$.

Ao mesmo tempo, é importante ressaltar que as comparações realizadas entre os movimentos de novos narradores orais na França e no Brasil, têm a intenção apenas de ampliar o entendimento sobre esses contadores de histórias que se formam recentemente, em várias partes do mundo, como é possível perceber nas diversas práticas encontradas, tanto em eventos específicos, quanto em redes na internet.

Aldanei Andrade (2012), ao estudar o contador de histórias no Distrito Federal, identifica um movimento de contadores de histórias na esteira das mudanças atribuídas pelos historiadores ao modernismo, por volta dos anos de 1950. A autora aponta as contribuições, sobretudo, de Malba Tahan, com sua rica pesquisa na formação de novos contadores de histórias e registro de contos orientais; Luís da Câmara Cascudo, com sua importante contribuição no registro da oralidade, por meio de contos, lendas, mitos e expressões orais, pesquisados em todo o país. Nesse sentido, pesquisas na área de Letras apontam, em cada Estado

\footnotetext{
${ }^{64}$ O Proler - Programa Nacional de incentivo à Leitura da Fundação Biblioteca Nacional, explicado na nota de número 22.

${ }^{65}$ Chamo a atenção para duas formas diferentes de grafar uma mesma palavra, sem a preocupação com certo e errado. Do meu ponto de vista, assumo contar histórias no lugar de estórias, por concordar com a inexistência de uma verdade absoluta que ganharia o status do "h", deixando a grafia de estória como "inventada", falta de compromisso com a verdade.
} 
do Brasil, aqueles que contribuíram com os registros das formas orais. Nesta mesma época, na vizinha Argentina, Dora Pastoriza Echebarne é apontada por Andrade (2012), como um dos primeiros trabalhos acadêmicos nos anos 1950, com o tema: narração. "El arte de narrar: ofício olvidado". E ainda, nesta mesma contribuição, aponta nos Estados Unidos o desenvolvimento de cursos sobre a arte de contar histórias para professores e bibliotecários, abordando a importância da oralidade para a formação do leitor, pressupondo a formação de um novo contador de histórias.

\begin{abstract}
Um narrador dos tempos modernos que busca no contador de histórias tradicional as bases para desenvolver esta atividade, saindo do espaço familiar e percorrendo novos espaços, como escolas, feiras do livro, livrarias, bibliotecas, teatros, shoppings, saindo do anonimato e passando a desenvolver uma atividade autoral, de certa forma profissional (ANDRADE, 2012, p. 26).
\end{abstract}

Hoje, considero que parte da academia reconhece o valor dos saberes populares, ampliando o número de áreas que investigam sobre o tema. Mas, fica a denúncia de que a maioria das escolas formais ainda conserva a leitura e a escrita como único, ou maior fundamento para suas práticas avaliativas ${ }^{66}$, dificultando sua valorização efetiva no cotidiano.

Um fato que me chamou a atenção durante a leitura da obra de Patrini (2005), se localiza numa das origens do movimento de contadores de histórias da atualidade, que encontrou nas Bibliotecas francesas um fértil local para seu desenvolvimento e crescimento, oferecendo cursos, oficinas, "hora do conto" e outros projetos.

\begin{abstract}
No nosso país, as décadas de 70 e 80 foram anos de grande produção do mercado editorial voltado ao público infantil e juvenil. Novos escritores e ilustradores de talento surgiram naquele momento. A partir da década de 90 , as pesquisas sobre a oralidade e a escrita se intensificaram. Nos grandes centros, pessoas começam a contar, muitas delas motivadas pelo trabalho das bibliotecárias (ibidem, p.40).
\end{abstract}

\footnotetext{
${ }^{66}$ Os trabalhos exigidos nas escolas, em sua grande maioria, em qualquer nível de ensino, do fundamental à pós-graduação, são, ainda hoje, cobrados na linguagem escrita, confirmando uma maior importância dessa linguagem, em detrimento de outras, sobretudo aquelas que são voláteis como o teatro, ou qualquer arte da cena, por exemplo, apesar de todo um discurso contrário. Ensinase a importância da arte, por meio das diversas linguagens artísticas e se cobra trabalho ou prova numa linguagem exclusivamente escrita. Parece que o discurso sobre a prática ainda é mais importante do que a própria prática.
} 
Para a autora, a biblioteca é "o viveiro do conto", local para prática de muitos projetos relacionados aos contadores de histórias, se referindo às bibliotecas francesas. Fazendo uma analogia ao movimento de contadores de histórias no Brasil, encontramos, também nas bibliotecas, uma das origens de um movimento que insiste e cresce, a olhos vistos, em nosso país. Em épocas não idênticas em sua origem, mas acompanhando recentemente a produção mundial, a produção de literatura infantil e juvenil no Brasil tem se revelado em qualidade e quantidade, com participações e premiações internacionais ${ }^{67}$, assim como temos o reconhecimento de nossos contadores de histórias, tais como: Bia Bedran, Rolando Boldrin, Roberto Carlos e outros.

Embora possamos considerar que um dos grandes responsáveis pelo surgimento e proliferação do movimento de contadores de histórias, no Brasil, tenha tido sua origem numa biblioteca, com o Proler, nem de longe é o lugar onde a atividade mais acontece. Isso porque, de maneira geral, não encontramos, no Brasil, uma valorização nos usos de bibliotecas públicas. São inexistentes, na maioria das cidades do interior, sobretudo quando saímos dos estados do sul e sudeste do país. Não é preciso recorrer a números para comprovar que não são todas as escolas que possuem biblioteca, apesar das orientações da legislação, tanto da LDB 9394/96, que está em vigor, como dos Parâmetros Curriculares Nacionais - $\mathrm{PCNs}^{68}$. Vale lembrar que, embora existam várias ações do MEC e das Secretarias de Educação estaduais e municipais para equipar as escolas com bibliotecas, os esforços não são, ainda, suficientes para o atendimento à demanda e a carência por uma educação de qualidade que incentive a leitura.

A pesquisa de Patrini (2005) ainda revela que os contadores franceses da atualidade são formados pelas bibliotecas públicas e tem lugar profissional garantido nas escolas, espaço instituído por programas de governo. No Brasil, não podemos falar da inexistência de programas de incentivo à leitura, literatura e contadores de histórias, até porque o Proler andou por grande parte do país e reconheço a existência de outros subsídios para grupos e ações individuais de contadores de histórias. Mas, com o país muito grande e desigual, depende de ações mais conjuntas e em muito maior número, para que sejam eficazes. As ações existentes

\footnotetext{
${ }^{67}$ Nossa mais recente premiação foi para Roger Mello, no prêmio de Literatura Hanz Christian Andersen, em 2014.

${ }^{68}$ Me refiro a qualquer uma das versões apresentadas, nos três níveis de ensino: educação infantil; educação fundamental e nível médio.
} 
não chegam a alcançar a maioria, surpreendendo, ainda, muitas pessoas na descoberta de projetos do gênero. Nos locais em que as instituições se uniram para continuar o projeto, este continua a existir, a exemplo de Joinville - SC, que comemora, em 2014, vinte anos de Proler, com um evento que homenageia os contadores de histórias.

Em minha observação, o movimento dos contadores de histórias, no Brasil, transita entre artistas (sobretudo atrizes e atores), pedagogos, terapeutas, recreadores e professores. No nível da graduação são várias áreas de estudo envolvidas, como já explicitadas na introdução. Talvez, essa seja uma razão da diversidade de interesse e envolvimento com a atividade.

Em muitos países, contar histórias é profissão. Patrini (2005) faz uma discussão sobre a questão da profissionalização do contador de histórias, mencionando que há uma grande confusão entre ser profissional ou amador, ficando cada um por definir seu próprio perfil, de forma bastante subjetiva. A dificuldade em separar profissionais, semiprofissionais e amadores está em encontrarmos amadores que recebem para se apresentar, e professores, por exemplo, que se apresentam sem receber por isso. Mais adiante, continua:

De uma forma ou de outra, contar é um costume ancestral que permite livre curso ao contador. Contar e ouvir é sempre uma aventura que provoca mudanças e que, eliminando as distâncias, encontra um pretexto para 0 reencontro e a troca de experiência (ibidem, p. 107).

O fato de existir ou não a profissão de narrador oral, pertence às discussões sobre as políticas públicas e desenvolvimento social do país, que foge ao âmbito da presente investigação, mas que não pode deixar de ser apontada como importante para uma discussão pertinente, nas esferas devidas. O fundamental de um contador de histórias é conseguir promover a troca de experiência em sua narração, onde as portas do imaginário de cada um podem se abrir às formas e sensações múltiplas provocadas pela audição e percepção do conto.

Minha primeira experiência, de forma mais sistematizada com os contadores de histórias, foi no projeto de extensão na UFG, grupo Gwaya - Contadores de Histórias, já mencionado, anteriormente, sendo objeto de investigação no meu mestrado, estudando a atividade de contar histórias na perspectiva do lazer. Esse grupo, tendo sido formado pelas ações do Proler, recebeu influências diretas do 
grupo Morandubetá ${ }^{9}$, composto por: Eliana Yunes, Lúcia Fidalgo, Celso Sisto e Benita Prieto. Esta última, por meio de sua empresa de produção cultural, tem fomentado muitos projetos, realizando, anualmente, um Simpósio Internacional de Contadores de Histórias, do qual já tive o prazer de participar, contando histórias na maratona $^{70}$. Prieto, em 2011, organizou uma publicação sobre Contadores de Histórias: um exercício para muitas vozes. Nesta obra, encontrei diversos autores que suscitam diálogos com minha experiência, que são mencionados em momentos diversos da escrita desta tese.

Outro evento internacional de grande relevância na área dos contadores de histórias é o encontro idealizado e organizado em São Paulo, por Regina Machado: Boca do Céu. Este, realizado bianualmente, desde 2001, traz experiências que explicitam qualidades e quantidades dos contadores do mundo atual, como referências importantes para situar o nosso movimento. Além de ser um espaço único de desfrute, deleite e prazer imenso em conhecer pessoas do mundo, que levam suas palavras a outras pessoas. Um encontro de emoções que se multiplicam a cada novo olhar, cheio de descobertas, reencontros, lugar de ouvir e ser ouvido.

Contar histórias, hoje, é profissão reconhecida, envolvendo cada vez mais pessoas nas mais diversas intenções e direções. O contador que aprende, aprende consigo mesmo e com o outro. Aprende a ouvir com os ouvidos que envolvem todos os sentidos, para deixar a história entrar.

\subsubsection{Um contador aprendendo com outro}

A convivência com o contador tradicional é, sem dúvida, uma forma concluída de aprender. Pode ser considerada como uma formação "pronta" e, é ao mesmo tempo, a forma mais antiga e a mais moderna de aprendizagem, no sentido de atender a um dos quatro pilares propostos pela UNESCO para a educação do século XXI: "aprender fazendo". A comprovação deste fato está na própria existência

\footnotetext{
${ }^{69}$ Morandubetá - grupo de contadores de histórias da Casa da Leitura da Fundação Biblioteca Nacional no Rio de Janeiro, um dos pioneiros no movimento de contadores de histórias no Brasil, sendo responsável pela criação de muitos grupos e ações isoladas de contadores.

${ }^{70}$ Nesse Simpósio, entre outras atrações e atividades é organizada uma maratona de 24horas ininterruptas de contos, com diversos contadores, de diversos países. Acontece no SESC Copacabana, com atividades envolvendo algumas escolas em pontos estratégicos da cidade. $O$ encontro é anual, tendo realizado sua primeira edição em 2003.
} 
dos contadores de histórias que foram aprendendo e desenvolvendo seu ofício, que é passado de geração em geração, da boca do avô para o ouvido dos netos.

Entretanto, hoje, com a diminuição do contador de histórias nas atividades cotidianas, não são todos que tem a oportunidade de convivência com contadores tradicionais. Se, no corre-corre do dia a dia, ninguém para mais para ouvir e contar histórias, essa referência passa a não existir para alguns. Como aprender a contar histórias sem encontrar quem conte, ou seja, sem ouvir e conviver com algum narrador oral? Por outro lado, se não precisamos de modelo, para que e porque conhecer outros contadores?

Considero, em primeiro lugar, que referência não é cópia. A necessidade de ouvir para saber contar está, também, no entendimento dos significados que um conto provoca e suscita no ouvinte. A experiência ensina, por si só, é preciso tê-la. O rico é quando temos a consciência da aprendizagem, por meio da observação, pois passamos a prestar atenção de maneira diferente.

Assim, neste item, serão exploradas as diferenças e semelhanças entre contadores de histórias, no sentido de entender "o que" e "como" nós, do segundo grupo, podemos aprender com os narradores orais do primeiro grupo, reconhecidos, naturalmente, por sua comunidade, com um extenso repertório. Recupero uma abordagem que reconheço iniciada no mestrado e que merece ser aprofundada, pelas riquezas que o contador tradicional traz em sua prática, sendo este o ponto de partida da aprendizagem de qualquer contador aprendiz.

O primeiro ponto escolhido para uma comparação entre os dois grupos de contadores é a formação do repertório. A tendência dos contos tradicionais é de serem arquetípicos, sendo apresentados, às vezes, em várias versões que impelem ao contador a responsabilidade de conhecimento para exercer suas escolhas. Não dá para negar que qualquer tipo de contador sempre construiu seu repertório com base em suas vivências individuais e coletivas e, de acordo com os objetivos e usos do conto que intenciona. Essas experiências pessoais do contador criam e recriam histórias que vão sendo recontadas e reelaboradas para cada contexto, como é característica das histórias populares.

O contador de histórias do mundo de hoje, que se assume aprendiz, tem ao seu dispor todo um repertório de contos tradicionais de várias culturas, que são hoje registrados, inclusive, em várias línguas, e, ainda, um repertório imenso de literatura de vários gêneros e estilos. Os dois tipos de contadores apresentam um repertório 
definido, entretanto, além de serem construídos de formas diferentes, atendem a desígnios múltiplos. Talvez possamos esperar que o aprendiz de contador que faz uso de contos literários, sobretudo da literatura infantil e juvenil, esteja com os objetivos voltados para o campo do incentivo à leitura, mas isso não pode ser considerado como regra.

Após a escolha da história a ser contada, cada texto pede e/ou oferece recursos diferentes, dependendo da leitura do narrador oral. Nesse sentido, a técnica é empregada de forma diferente nos dois grupos de contadores, os tradicionais e os aprendizes. Há aqueles que sentem necessidade de ensaiar e elaborar sua performance, experimentando e escolhendo elementos que enriquecem a narração. O contador tradicional, geralmente, aprende a contar na própria experiência do contar, no improviso, sem aviso prévio, com o público já presente. Domina a linguagem oral, tanto na variedade de vocabulário e expressões de linguagem, quanto nas construções das estruturas das histórias. Sabem como funcionam os enredos, com suas fórmulas de início e desfecho, por isso sabe dar ritmo à história. Quando se conhece muitos contos populares, fica possível identificá-los em sua estrutura, prevendo caminhos, improvisando as palavras.

Mas nem todo mundo se sente à vontade para recontar uma história com suas próprias palavras, sobretudo se tiver que improvisar. Conheço ótimos contadores de histórias que decoram cada palavra do texto a ser narrado, no entanto, conseguem a naturalidade do contador, como se as palavras brotassem naquele momento. Nem por isso são melhores ou piores. Reconheço, também, aqueles narradores orais com maior capacidade de improviso, que recontam as histórias com suas próprias palavras, mais próximos do contador tradicional.

Tive uma experiência, no mínimo contraditória, mas, ao final, reveladora, na leitura de um texto de Simone Grande, no livro organizado por Giuliano Tierno, onde ela revela que em sua experiência "contar histórias é um esforço sem força, um deixar levar conduzido, por uma brincadeira séria" (2010, p. 128). Expondo sua experiência pessoal, assume utilizar-se de sua formação de atriz, para a composição de suas performances como contadora de histórias, embora considere que "a sensação de troca, de cumplicidade que acontece entre narrador e seu público é algo mágico, que o teatro ainda não havia me dado" (ibidem, p. 130). A contradição é que durante anos eu negava qualquer relação ou menção de associação do saber do contador com as técnicas e saberes da arte teatral. Hoje, não só concordo com 
ela, como aprendi a rever mais de perto os dogmas construídos neste grupo de contadores de histórias. No início, eu acreditava que para contar uma história seria necessário ensaiar muito, até as palavras serem internalizadas e ficarem naturais. $\mathrm{Na}$ minha primeira experiência com o grupo de contadores, confesso ter acreditado em maneiras certas e erradas para se contar histórias. Porém, não durou muito, os caminhos se diferenciaram e o mundo das artes se descortinou à minha frente, me fazendo entender a possibilidade de uma multiplicidade de entendimentos simultâneos e direções plurais. Ou seja, as pessoas sentem e pensam de formas diferentes, que devem ser respeitadas em sua individualidade. Quando experimentei improvisar, soltar mais as palavras, inclusive incluindo os ouvintes de formas particulares na narração, meu trabalho melhorou muito em eficiência (interação com o público) e satisfação pessoal. É preciso internalizar a história para contá-la, não necessariamente, decorá-la. Ademais, o gostoso é contar junto, “com” a plateia, e quando isso acontece, por vezes, nascem novos significados que suscitam novos improvisos.

Ao recontar improvisando as palavras, o repertório vai misturando pedaços de histórias e criando outras, crescendo em qualidade e quantidade, justificando o dito popular: "quem conta um conto e aumenta um ponto". Minha mãe contava histórias para minha filha, primeira neta, e ambas se orgulhavam de colecionar histórias de "chapeuzinhos" de cores diferentes. Chapeuzinho Vermelho, a nossa velha conhecida; Chapeuzinho Rosa e Chapeuzinho Azul, uma versão da Moura Torta; Chapeuzinho Amarelo, escrita por Chico Buarque de Holanda; Chapeuzinho Verde, cuja versão adaptada de Robin Hood foi inventada numa tarde comprida de histórias, assim como a "História do Chapeuzinho Incolor" que elas não conseguem lembrar o improviso, até hoje.

Embora a discussão sobre repertório não esteja, nem de longe, abordada em todos os seus aspectos mais importantes nesta parte da discussão, reservo o quarto capítulo para a continuidade da abordagem do tema, devido à sua complexidade e relevância na contribuição para o contador de histórias. As escolhas, por mais que sejam múltiplas e diversas, são escolhas e exigem conhecimento, pois incluem consequências e, é com base nessa escolha que o contador define seu repertório e, consequentemente, sua atuação.

Em relação ao uso de técnicas para a narração de uma história, embora todos os contadores façam uso de alguma, o tradicional e o aprendiz a desenvolvem de 
formas diferentes. Enquanto o primeiro grupo de narradores orais age de forma intuitiva, experimentando e explorando o que conhece, o segundo grupo estuda, explora e experimenta formas de chamar mais atenção do público, despertando-lhes participação por meio de técnicas já experimentadas por outros, que são adaptados por cada contador à sua maneira, em sua história.

O repertório de cada contador tem relações diretas com o público a que se destina. Se antigamente o ouvinte era cativo, garantido pelas reuniões familiares ou entre vizinhos, hoje é um público a ser conquistado. É uma atividade bem aceita nas escolas, por isso deveria ser levada mais a sério, para um trabalho de formação de plateia, como aponta Desgranges (2003). O contador tradicional, do primeiro grupo, tem maior facilidade de colocar alguém da plateia dentro da história, dando maior veracidade e envolvendo afetivamente ouvintes e contador. Os contadores do segundo grupo aprendem, com o narrador de tradição, a permitir uma interação maior entre a plateia e a história que está contando, sem, contudo, atrapalhar o entendimento ou o ritmo da história. Essa forma carinhosa e afetiva de envolver o ouvinte é comum nos narradores orais do primeiro grupo. Instintivamente, as mães colocam os nomes dos filhos no lugar de princesas e heróis das histórias que contam. Estudando seus significados é possível criar técnicas que conseguem aproximar o ouvinte do conto.

A memória é um ponto identificado como semelhante, entre os dois grupos de contadores, pois é inerente a qualquer tipo de contador de histórias, tradicional, urbano, aprendiz, ou qualquer outra alcunha, embora estruturada de maneiras diferentes, porque são tratadas pela cultura oral e escrita, de formas diferentes. $O$ hábito de anotar e ler, quando precisar, acaba por afastar o exercício constante da memorização. A consequência do pouco uso da memória é o esquecimento, que pode ocorrer durante uma narração, por exemplo.

A palavra e o ritual são, enfim, os outros elementos pertencentes a todos os tipos de narradores, apontados nesta comparação, conservando sua importância, forma e significados. A comunhão do conto pela palavra pode ser considerada como característica fundamental da narração de uma história. É quando contador e ouvinte atribuem sentido e significado ao que está sendo narrado, abrindo as portas infinitas do imaginário. A palavra tem poder de formar imagens, suscitar emoções e despertar sentidos. Não é por acaso que existem estudos específicos sobre a palavra, como por exemplo, no livro de Gislayne Matos (2006). 
A força da palavra provoca reações diversas: uma vez contei uma história do repertório da pesquisa de Pirenópolis, na aula inaugural do curso de Licenciatura em Teatro, na UFG, sendo cobrada, por três dias seguidos, pela linguiça que havia na história, que tinha despertado desejo até numa vegetariana, tal foi a força da imagem construída na narração. Anos depois, ainda sou lembrada como "a professora da linguiça, ou a contadora de histórias". No capítulo sobre as técnicas da linguagem corporal será explorada a palavra do contador, em ação. No momento, o foco se limita na presença e significação da palavra para a comunhão, ou seja, para o entendimento do conto.

O ritual se estabelece na própria ação, mas é propiciado pela ocupação do espaço, em círculos ou semicírculos, que, do meu ponto de vista, é a melhor forma de organização do espaço para uma narração. O círculo tem a propriedade de igualar as pessoas, colocar todos em uma mesma importância, em comunhão. Quando se trata de contar histórias, o texto é que merece ser o centro das atenções. É uma atividade de troca, portanto, o círculo é mais aconchegante por permitir todos, ao mesmo tempo, no mesmo campo visual. Rompem-se as hierarquias e todos podem ser considerados iguais, de frente uns para os outros.

Cada contador vai construindo seu próprio ritual, com a forma que mais the agradar. Alguns exemplos podem ilustrar a prática de alguns contadores que costumam cumprir algum rito, antes de iniciar sua sessão de histórias, como que preparando um clima. Contam que Regina Machado gosta de acender uma vela, antes de iniciar a narração de uma história, pois o fogo remete à ancestralidade e à reminiscência, lugar dos contos tradicionais. Já vi uma contadora jogar pétalas de flores no chão, com aromas agradáveis, criando clima aconchegante e gostoso. Dona Benta fazia adivinhas, Gilka Girardello canta a cantiga do limão, 'sorteando' a vez de um contador, alguns se limitam a mencionar o título e fonte da história para iniciar a contação, e outros, nem isso.

Há mais de oito anos gosto de promover um piquenique com histórias, em finais de disciplina e/ou finais de semestre, com alunos do grupo de estudos. Mas já andei descobrindo que não sou a única com a mesma ideia! Acredito que criar climas de aconchego para a escuta faz parte do ritual do ato de contar histórias, deixando liberdade de escuta aos interessados e incentivos àqueles que querem se aventurar pelo encanto das palavras. Penso que o piquenique remete a uma 
celebração em volta do fogo ${ }^{71}$, porque aproxima as pessoas, aquecendo memórias e emoções, aquecendo a boca com palavras e/ou petiscos, que quando presentes ${ }^{72}$, chegam cheios de histórias próprias.

O clima que criamos antes das histórias, em nosso mundo ocidental, tem o sentido de um aviso aos presentes sobre o que vai acontecer, como um convite para a saída do estado cotidiano, do mundo real. Uma abertura para a presença no mundo imaginário, que pertence à outra esfera, sem limites ou censuras. $O$ mundo das histórias pertence à outra realidade, e contar e/ou ouvir uma história nos coloca em contato com o ato de imaginar, remexendo memórias e despertando emoções. Uma presença natural e espontânea, por isso agradável, do contador de histórias faz parte do reconhecimento de sua importância e das histórias que carrega consigo.

\subsection{Quem é o contador de histórias?}

Contar histórias é dialogar

Em várias direções:

Na da arte, na do outro, na nossa!

Celso Sisto

Reconhecendo que a atividade de contar história, por milênios, tem conservado seu poder de suscitar o sonho e a fantasia nos ouvintes, esta pesquisa tem por objetivo fornecer subsídios para que qualquer contador, na contemporaneidade, possa se aperfeiçoar na arte da narrativa, conquistando cada vez mais ouvintes, espaços diferentes para sua atuação e ampliando um público que não tem distinção de idade ou qualquer outra categoria. Portanto, o foco aqui proposto está no contador de histórias de hoje, que procura por uma construção ou formação específica para desenvolver sua arte. Aquele que se pergunta: como se conta uma história? Para que contar histórias? Por quê? Para quem? O que significa? O que envolve? Qual a responsabilidade de um contador de histórias que se constrói na contemporaneidade?

\footnotetext{
${ }^{71} \mathrm{~A}$ metáfora "em volta do fogo" é utilizada por vários autores, por nos remeter a um tempo originário. Ver referências em: Regina Machado (2004a.); Robson Santos (2011); Paulo Siqueira (2011); Cléo Busatto (2011).

${ }^{72}$ Para mim, o que caracteriza o piquenique é uma toalha no chão, ou uma enorme "toalha de retalhos" montada com diversos panos e lenços, um ao lado do outro, e livros ou comidas que as pessoas levam, muitas vezes junto com receitas e historias de como se faz, onde trocam-se experiências, imagens e emoções.
} 
Optando pelo diálogo entre a minha vivência e as práticas dos diversos contadores que registraram suas experiências, para encontrar os fundamentos que orientam a construção de um narrador oral, na atualidade, passo a buscar os termos utilizados nos diversos estudos, na intenção de definir o sujeito dessa pesquisa. Diante desse desafio, procuro entender como os autores têm nominado e/ou tipificado os contadores de histórias da atualidade, a fim de me posicionar, revelando qual deles é o sujeito dessa pesquisa, em que o objeto é a formação/construção do narrador oral.

Bia Bedran utiliza as nomenclaturas de contador tradicional e contemporâneo, assim descritos:

\begin{abstract}
A arte narrativa se manifesta tanto no contador tradicional, cujas histórias foram criadas e recriadas ao longo do tempo através da narração de sua experiência e de sua memória, quanto no contador contemporâneo, que se instrumentaliza através da pesquisa, da leitura e a insere na prática pedagógica (BEDRAN, 2011, p. 61).
\end{abstract}

Assim como a maioria dos autores, concordo e também assumo o contador tradicional para aquele que, de certa forma, sempre existiu em sua comunidade. Quanto ao contador contemporâneo, terá seu espaço de discussão, mais à frente.

Cleo Busatto (2006) utiliza o termo contadores tradicionais, "para aquele sujeito contador que se revela no seio de sua comunidade" (p. 41). Aquele que é reconhecido pelos frequentadores de seu grupo ou sociedade, trazendo sua plateia cativa e tendo aprendido naturalmente, por meio das tradições orais. Em minha dissertação de mestrado, chamei-os de 'contadores de raiz', com o sentido de identificá-los como primeiros oradores, diferenciando-os dos contadores da atualidade, que se multiplicam em formas, conteúdos e contextos. Entretanto, reconheço o equívoco, naquele momento, de um entendimento ainda marcado por uma visão um tanto fragmentada, querendo identificar contadores do presente e do passado.

Andrade (2012) me mostrou que "tanto o historiador quanto o contador de histórias contam histórias buscadas no passado, ressignificadas no presente e lançadas para o futuro" (p. 18). Com isso, ao invés de limitar nosso universo, ele parece se expandir ainda mais, incluindo a história oral e os personagens que a envolvem. 
O fato é que reconheço, hoje, uma diversidade tão grande de contadores de histórias, que se torna impossível abordar todas as formas, determinando um posicionamento na delimitação do contador de histórias que pertence a essa investigação. Assim, sem estabelecer qualquer valoração aos diferentes tipos de contadores de histórias que existem na contemporaneidade, o reconhecimento de sua variedade se faz necessário ao recorte a ser feito para o sujeito e objeto da presente pesquisa. A experiência de Bandini revela um contador perto dos livros, diferenciando daqueles cujo contato é predominantemente oral:

\begin{abstract}
Pessoalmente faço uma distinção entre o ler histórias (sem grandes ênfases, ler o conteúdo exatamente como está escrito); contar lendo (seguir a leitura, enfatizando as expressões sugeridas pelo conteúdo e pontuação); contar ou narrar (utilizar de minhas palavras para contar a história, na realidade, adaptando o texto ao meu "jeito próprio" de passar o conteúdo, atualizando-o caso acredite ser necessário), e declamar (dizer o texto totalmente decorado) (BANDINI, 2012, p. 82).
\end{abstract}

Em sua atuação, Alice Bandini oferece cursos há 5 anos, em 3 turmas - na Biblioteca Narbal Fontes, no município de São Paulo, afirmando que a procura é sempre maior que a oferta. Seu objetivo é formar multiplicadores, promover a tradição oral e, por meio dela, incentivar a leitura, conscientizando as pessoas do valor e do poder do ato de narrar histórias.

Uma atividade possível de ser enriquecida com adereços e outras artes e de acontecer em qualquer espaço, instituição, cidade, sem necessidade de grandes estruturas. Uma atividade interativa, carregada de significados, algo fundamental em nossa sociedade (BANDINI, 2012, p. 92).

Enquanto o imaginário do contador de histórias passeia por distantes civilizações, conectando a ancestralidade do ato de narrar, ressurge em meio às sociedades mais urbanizadas, sobretudo, nos grandes centros, esse "novo contador" de que fala Cléo Busatto, que também identifico nas palavras de Eliana Yunes:

A narração de textos autorais sabidos de memória ou de contos de herança popular tornou-se pouco a pouco, uma prática sedutora e fascinante, capaz de reunir um público heterogêneo em idade e interesses para simplesmente ouvir histórias retomando o contato com a tradição da palavra (2012, p. 61).

O contexto a que se refere Eliana Yunes inclui certo preconceito, de que contar histórias não teria nada haver com as práticas de leitura ou letramento ${ }^{73}$, que,

\footnotetext{
${ }^{73}$ Letramento é o nome conhecido, hoje, pelas pessoas que estão se alfabetizando.
} 
por outro lado, renderam boas discussões entre os teóricos da área, que revelam tanto as relações intrínsecas entre contar e ler, como também, mostram a importância das duas formas, na formação do ser humano. E, não são apenas as formas de contar que se diferenciam. Há que se considerar as diferenças nos conteúdos e tipos de histórias que serão discutidas na formação do repertório, no quarto capítulo, que, igualmente, contribuem na tipificação dos contadores da atualidade.

Por este ponto de vista, se explicitam a existência de diferenças claras entre os contadores tradicionais e estes que visivelmente se relacionam de alguma forma com práticas pedagógicas, a quem Bedran (2011) chamou de contador contemporâneo e Vivian Rocha chamou de contador urbano. Não somente com o livro, Busatto (2006) trás referências de que, na atualidade, o contador de tradição e o contador contemporâneo convivem em um mesmo espaço, marcados por tempos e contextos distintos.

Pondero que a nomenclatura de contador contemporâneo pode sugerir confusões, pela coexistência das várias formas de contar, embora não sejam contrárias nem excludentes, e, por vezes, estejam presentes de forma simultânea. Nesta tese, seria complicada a opção pelo termo contemporâneo, justamente pela contemporaneidade do contador tradicional, que envolveu parte de minha experiência, revelando essa possibilidade.

Gilka Girardello organizou o livro: Baús e Chaves da Narração de Histórias, inspirada na "canastrinha da Emília", desejando ser um convite à ideias para os contadores de histórias, por meio da experiência dos textos de suas próprias histórias. Identifico-me com a lembrança/metáfora usada pela autora que, ao se construir contador, cada um coleciona suas vivências, escolhas, acervos, relíquias e badulaques para serem transformados em histórias contadas (GIRARDELLO, 2004). Como um colecionador de ideias, lembranças, emoções, memórias. Daniel Santos (2004) é um dos convidados da autora acima. Contador de histórias e psicólogo, conta que em sua cidade, no interior de Santa Catarina (Itajaí), os narradores orais são chamados de "papudos" ou "trovadores". Em seu artigo, refere-se aos contadores tradicionais e modernos, considerando múltiplos objetivos no ato de contar histórias: para deixar felizes (contador e ouvinte); estimular o hábito de leitura; contribuir com a educação formal, quando é contada nas escolas; se reconhecer como ouvinte, em outros tempos e/ou contextos. 
A reflexão apresentada sobre os contadores de histórias, por Andrade (2012), tem o olhar da historiografia, alargando a área de atuação e construção de um contador de histórias.

Ao utilizar a oralidade como campo metodológico a autora adota a tipologia: tradicional e moderno, utilizando estes termos nas entrevistas, como estratégia que permitiu observar a coexistência de contadores de histórias tradicionais e modernos no Distrito Federal. (...) Vale ressaltar que essa separação é apenas analítica, pois mesmo o contador de histórias moderno pode, em sua forma de narrar, ter o estilo tradicional (ANDRADE, 2012, p. 15).

O questionário utilizado para o levantamento dos contadores do Distrito Federal fornece dados que comprovam uma quantidade considerável de contadores, com variações em termos de: idade, procedência, tipo de repertório, objetivos e periodicidade, local de atuação, recursos utilizados, além de características individuais.

Essa variedade, que posso conceber ser ainda maior, se manifesta de infinitas formas, indicando que ao querer construir um contador de histórias, na contemporaneidade, livre de formas prontas, o sujeito contador pode ser tanto tradicional como moderno ou contemporâneo, indicando este parâmetro como insuficiente para a delimitação do sujeito dessa pesquisa.

Conforme afirmação de Mauro Brant (2011), os atores ainda são minoria no mundo dos narradores orais, que começam, aos poucos, a descobrir essa vertente. Este é, também, um dos motivos que justifica esta pesquisa nesta área.

De todos os tipos existentes de contadores de histórias, do mais antigo ao mais atual, com todas as alterações decorrentes da dinamicidade da cultura, concordo com Busatto quando diz que, "permanece o que é essencial: a condição de encantar, de significar o mundo que o cerca, materializando e dando forma às nossas experiências" (2006, p. 10).

Dessa forma não se trata de delimitar o sujeito apenas, pois este está balizado por sua escolha pessoal. Ou seja, o contador de histórias, sujeito dessa pesquisa, é aquele que faz uma opção por se construir narrador oral, pesquisando, estudando, aprendendo, criando e se responsabilizando por seus objetivos e ações. Trata-se, igualmente, de delimitar o objeto da pesquisa ao qual a investigação estará em permanente foco: a formação/construção desse sujeito, com vistas à sua autonomia e responsabilidade, portanto, livre. 
Como toda escolha tem seus riscos inerentes, acredito que a delimitação no campo da pesquisa é justamente o limite que permite o aprofundamento desejado. Ao privilegiar minha experiência pessoal, procuro entender quem é o sujeito: "aprendiz de contador", entendendo que todos que querem podem conquistar essa aprendizagem, ao não se reconhecer como narrador oral. E, ao eleger a formação/construção como objeto a ser investigado, procuro identificar os princípios e fundamentos que participam dessa transformação.

Embora por caminhos e informações diferentes, encontrei grande identificação com os objetivos citados por Shedlock ${ }^{74}(2004)$ para se contar histórias na educação, seja dentro ou fora da escola: alegria dramática; senso de humor; corrigir tendências (sem didatismo); exemplos no lugar de prescrições; desenvolver a imaginação. Estes pontos de encontro estão presentes nos diálogos tratados entre as experiências, no decorrer do texto.

Outra identificação aconteceu com Gislayne Matos, em palestra no Encontro de Comemoração dos Vinte Anos de Proler, em Joinville - SC, em 2014, quando esta contou de seu próximo livro a ser lançado, sobre a formação do contador de histórias, nas perspectivas do poeta e do artesão. O poeta pela busca de sua própria experiência, por meio da poesia guardada para dar forma ao que o contador conta. Artesão na descoberta e construção de ferramentas e recursos de sua linguagem corporal. Penso que meu trabalho irá manter vários pontos de contato, encontrando o poeta na presença do contador, tratada no terceiro capítulo, e o artesão, no quinto capítulo, que reflete sobre a linguagem corporal do contador de histórias.

As características apontam um aprendiz que procura investigar repertório, linguagens, público e outros recursos ou elementos para sua narração. $O$ que delimita o sujeito dessa pesquisa é a procura por uma construção, com a preocupação com as consequências de seu fazer, o sujeito que se assume como contador de histórias e desenvolve sua arte. O objeto da investigação procura informações para a melhoria da performance do contador, considerando a estética e as possibilidades de interação entre contador e ouvinte, na comunhão do conto, respeitando a individualidade de cada um. O caminho agora se encontra na

\footnotetext{
${ }^{74}$ Interessante perceber que a inglesa publicou sua obra em 1915, pela primeira vez, há cem anos e continua fazendo valer suas sábias generalizações, como anuncia Girardello na apresentação da autora, em seu livro: Baús e Chaves da Narração de Histórias.
} 
compreensão e identificação dos fundamentos que compõe a presença do contador de histórias. 


\section{CAPÍTULO 3 - A PRESENÇA DO CONTADOR DE HISTÓRIAS}

Os melhores narradores são aqueles que sabem escutar.

Gilka Girardello

O fundamento que inaugura a aprendizagem de um contador de histórias, do meu ponto de vista, é ouvir histórias. Ouvir, em seu significado mais amplo, abrangendo vários sentidos, instituindo o ambiente propício para a narrativa. "Este estado de espírito, o ouvir, que pede quietura interna, qualidade seminal para a audição plena, foi substituído pela pressa e pelo agastamento típico de quem já detém informações suficientes para viver" (BUSATTO, 2006, p. 20). Entretanto, ainda hoje encontramos um ouvido disposto e um contador animado para contar.

Ao concordar com a autora que a capacidade de escuta é uma realidade que tem se tornado cada vez mais escassa, nos dias de hoje, observo, ao mesmo tempo, um crescente interesse pela narração oral, com intenções advindas de pessoas de diversas áreas, interesses, idades, e, portanto, objetivos diversos. No atendimento a essa demanda, com cursos e oficinas, no Brasil, apoio e concordo com aqueles que têm buscado o despertar de um ouvinte/contador, ou seja, um contador que inicia por tomar consciência de sua capacidade de audição. Esse ouvir é conquistado pela interação entre o narrador oral e sua plateia que, em um processo de coautoria, significam juntos o que está sendo narrado, estabelecendo um 'contar com', uma comunhão do conto, vinda da voz, dos olhares e expressões do contador, penetrando nos ouvidos, olhares e expressões dos ouvintes. "Toda narrativa só tem sentido quando compartilhada e todo posicionamento só tem sentido quando assumido" (ZURK, 2008, p. 128). O compartilhar corresponde ao ouvir e significar, atribuir sentido ao que é falado e escutado; o posicionamento se relaciona à função social e cultural que cada contador assume. Ao abordar sobre a força agregadora de uma narração, Cléo Busatto se posiciona:

A narração oral é política e transgressora quando agrega os ouvintes, seja na rua, na praça, e subverte o tempo linear, a pressa, quebra a resistência em ouvir a voz do outro, rompe as defesas do passante com a graça do contador, liberta 0 sujeito das normas e oferece indagações, questionamentos, alegria, riso, descontração, aproximação, harmonia, fraternidade (BUSATTO, 2006, p. 35). 
Não há como negar ou fugir da capacidade de penetração das histórias, observada na interação entre o contador e o ouvinte, seja em um contador na rua, em um palco, na cozinha de casa, ou na roda de fogueira. A força da narração oral aparece quando os ouvintes, de forma esperada ou não, se aglomeram em volta de um contador, no silêncio do ambiente, ajudando a história a fazer barulhos dentro de si.

Compreendo estes últimos tempos de crises e polarizações, no mundo e, especificamente, no Brasil, nesse início do século XXI, como marcados por um ambiente em que, diante de um arsenal de aparelhos tecnológicos de informação, as pessoas pouco se aproximam umas das outras, interagindo, cada vez menos, com o outro, por meio da oralidade, de forma presencial. Momento em que a sociedade de consumo fortalecida pelo "Ter", impõe padrões que afastam as pessoas do "Ser", dificultando a liberdade de construir sua própria identidade. Em momentos como este, busco o que encontrei nas palavras de Mendes: "Penso nas histórias que fabricam o Ser e que nos fazem rir, chorar, encantar, refletir, educar e sonhar" (2011, , p. 205). Ou seja, que nos faz emocionar, sentir, ser. Assim, reflito na necessidade de um reencantamento do mundo atual, concordando com Busatto.

\footnotetext{
A contação de histórias como um instrumento capaz de servir de ponte para ligar diferentes dimensões e conspirar para a recuperação dos significados que tornam as pessoas mais humanas, íntegras, solidárias, tolerantes, dotadas de compaixão e capazes de "estar com" (2006, p. 12).
}

Portanto, a contação de histórias pode ser considerada como um ato político e, consequentemente, educativo, por ser capaz de transformar, quando consegue fazer-se presente, alcançando os ouvintes, tornando-se um ato solidário.

Procuro, neste capítulo, entender de que maneira, ou seja, como o contador consegue uma aproximação com seu público, no momento da narração, provocando-Ihes não só o prazer momentâneo, mas a busca pela repetição desse prazer posterior, verificado nos comentários de: "quero mais", "é tão bom". Busco a compreensão na construção de sentidos e significados dos ouvintes ao que é dito pela memória do contador; na provocação de emoções e imagens, que são construídas durante a narração, pelo contador e pelo ouvinte, cada um da sua forma. Assim, a investigação aponta para a sistematização dos componentes que favorecem a presença do contador, garantindo que a história seja compreendida (ou 
significada) pelo público, gerando influências mútuas em quem conta e em quem ouve.

Embora esta pesquisa não se aprofunde nos estudos e teorias da recepção teatral, essas me permitem assinalar pontos que interessam ao foco já delimitado anteriormente, nas contribuições da construção de um sujeito contador. A não opção pelas teorias da recepção e da comunicação se deve menos pelos aspectos de componentes da narração nelas contidas, e sim, pelo foco deste capítulo, que envolve o entendimento da 'comunhão do conto', isto é, do momento da narração em que contador e ouvinte significam juntos, as palavras da história se fazendo presentes, cada um a seu modo, com sua compreensão de mundo. A aparente mistura entre contador e ouvinte se desfaz na análise de cada ação: o contador conta, o ouvinte ouve e, os dois, ao mesmo tempo, significam juntos as palavras do conto, ainda que de forma diversa. Assim, busco a presença do contador nessa interação entre narrador oral e ouvinte, procurando os elementos que envolvem a escuta. Um lugar que pertence aos dois, contador e ouvinte, o lugar da escuta. "Vejo o contar histórias como um ato social e coletivo, que se materializa por meio de uma escuta afetiva e efetiva" (BUSATTO, 2006, p. 13). Uma escuta que acontece em um só instante e que pode trazer significados múltiplos.

Assim, procuro entender o que contribui com a presença do contador de histórias em seu exercício de fazer o outro ouvir. Ou seja, investigo os componentes que participam do instante em que o conto é narrado e 'significado' pelo contador e ouvinte, simultaneamente, quando o contador entende que ele não conta um conto 'para' uma plateia, e sim, 'conta com' essa plateia e que o texto é mais importante que sua própria performance, ou melhor é a própria performance. Persigo aquilo que está entre o contador e seu ouvinte, que os une, que provoca encontros.

Para Regina Machado, "A natureza fundamental da narração está na qualidade do encontro entre as pessoas" (2004a., p. 34), ocorrência que me faz investigar o que envolve essa qualidade entre contador e ouvintes, capaz de promover o encontro entre as pessoas. Fazer nascer uma história depende de quem conta e, ao mesmo tempo, de quem ouve, "O anúncio de uma história tem a aura sagrada. (...) Esse momento é único e, quando desperdiçado, lança para além a possibilidade de uma verdadeira interação. Interação como troca de "inteirezas" entre narrador e ouvinte" (SISTO, 2004, p. 84). É este encontro, a troca de inteirezas, a comunhão do conto, a vivência de alteridade, na produção de sentidos 
comuns e diferentes, no despertar de ressonâncias e afetos, que estou atribuindo à presença do contador de histórias.

\begin{abstract}
É nesse sentido profundo do narrar, esse lampejo em direção ao outro, que é indissociável da condição humana para os autores que estamos revisitando, aquilo que norteia as iniciativas mais interessantes de promoção da narração oral, no campo das artes, da memória cultural e da educação (GIRARDELLO, 2014, p. 15)
\end{abstract}

Ao elaborar um roteiro teórico-literário, pensando o papel da narração oral em suas possibilidades poéticas e formas artísticas no cenário contemporâneo, Girardello (2014) sugere autores que coincidem com minha busca pelos princípios e fundamentos que constroem o sujeito narrador dos tempos atuais.

A narração oral é uma performance do ponto de vista de sua imprevisibilidade e vitalidade, existindo apenas no momento de encontro do contador com o ouvinte. "Para Zumthor, a competência da performance oral não é da ordem de um saber fazer, como poderia parecer à primeira vista, mas sim de um saber ser" (GIRARDELLO, 2014, p. 7/8), uma presença em que o corpo está inteiramente implicado e cujo estatuto poético é definido pelo critério do prazer (ibidem, 2014). Para a autora, o "valor único do que ocorre entre quem conta e quem ouve" é dado pela ênfase na presença do narrador, que no pensamento de Lyotard (GIRARDELLO, 2014), envolve uma tripla competência: saber fazer; saber dizer; saber ouvir.

O imprevisível se abre ao outro, criando espaços de interação, de trocas, de construção de imagens na significação do conto e de vivências de emoções suscitadas pelos recursos da narração, envolvendo a memória de ambos, contador e ouvinte e a espontaneidade do narrador oral, conquistada pelo saber, conhecimento do conto. Quero dizer com isto que memória, imaginário, emoção e espontaneidade foram os elementos eleitos por mim, para compreender a magia que envolve 0 ato de contar de histórias. Aquilo que dá o poder da cura e da atenção a quem sabe usar as 'palavras certas'. Elementos que trazem a presença do contador e ouvinte, ao mesmo tempo, na significação das palavras do conto. Aquilo que presentifica a ação de contar, envolvendo contador e ouvinte, ou seja, aquilo que faz a presença do ouvinte ser garantida pela palavra do contador.

Em outras palavras, "Tornar o ouvinte cúmplice e participante do conto implica em abrir espaços para que ele o ressignifique" (BUSATTO, 2006, p. 74). Estou 
chamando de presença, esse espaço que o narrador oral cria em sua fala, aproximando o ouvinte, atraindo-o para dentro do conto, para o lugar da significação da cumplicidade.

$\mathrm{Na}$ fala de Sisto, "A entrega mútua instaura a vibração conjunta, um convívio sensível, decorrente dos entusiasmos de ambas as partes. É como vibrar em uníssono" (2004, p. 89/90). O ouvinte sabe que é levado pela fantasia, e se permite acompanhar o narrador oral pelas imagens e emoções que o conto vai fornecendo a ambos. Essa vibração é o lugar do encontro, do espaço de significação. Associo, também, essa presença com as ideias de Girardello (2014) ao anunciar a narração como conspiração, porque é uma atividade solidária, compartilhada entre quem conta e quem ouve, uma interação cúmplice na formação das imagens e significações do conto (GIRARDELLO, 2014). O instante, marcado pela exposição do contador, revelador de sua presença, se encontra em todos os tipos de contadores que realizam essa atividade com competência, tanto aqueles que já existiram, quanto os que existem hoje, no presente. São aspectos que envolvem a realização da magia do conto, no momento da narração, que reaviva a história com todo seu poder de acordar o outro. A diferença é que um contador constrói o domínio desses fundamentos com ajuda consciente, estudos e práticas, o outro contador se constrói intuitivamente e sabe se fazer presente. Saber fazer-se presente, de modo que a história contada penetre no ouvinte, ou de outra forma, atraia o ouvinte para dentro da narrativa, é a busca do contador aprendiz.

Os aspectos responsáveis pela manutenção da presença de um narrador oral, que garantem a atenção e compreensão da história, por parte do ouvinte, são mais profundos do que um simples falar e ouvir, por ser uma presença que articula uma interação entre ouvinte e contador, na significação das palavras ditas. O contador de histórias conta 'com' o seu público ouvinte e, com este entendimento, garante sua presença. Por isso, este trabalho é marcado pela complexidade de teorias que fogem a respostas simples ou exatas, admitindo ser possível estudar a interação que ocorre durante a ação do contar e ouvir.

Concordando com Celso Sisto, "Poderíamos afirmar que o trabalho do ouvinte torna-se interativo (...) na medida em que a forma de contar propõe uma decifração" (SISTO, 2012a, p. 47), ainda que os ouvintes entendam de formas variadas. A forma de contar auxilia o contador no compartilhar do conto com seu público, deixando 
brechas para cada um estabelecer suas próprias conexões, numa perspectiva de significação do conto.

Um narrador oral presente é aquele que participa, interagindo com seu público, estimulando-o a compreender e participar da história, como esta permitir, como ilustra a experiência de Regina Machado:

\begin{abstract}
A presença do narrador orquestra e incorpora o imprevisível a serviço da história. Estar presente é saber incluir o acaso - uma campainha que toca de repente, alguém que abre uma porta e entra sem ser esperado, uma criança que faz uma pergunta, outra que começa a falar do pai ou do lanche no meio da narração - fazendo caber tudo isso na situação narrativa (2004a., p. 81).
\end{abstract}

$E$ ainda, sem perder os significados que garantem o fio da história. Estar presente é saber o que dizer, em cada reação de seus ouvintes, sem se desviar da história, para que os outros ouvintes possam continuar viajando pelo conto. Mas, não é tão fácil, exige conhecimento e prática, que constroem a competência do narrador oral.

"É muito comum as pessoas acharem que sabem contar histórias - e nós não duvidamos disso - mas daí a fazer com que esse "ato" se transforme numa obra de arte ou num exercício artístico é um salto muito grande" (SISTO, 2012a, p. 41). Sem querer que uma afirmação dessas soe como excludente, concordo com Celso Sisto, lembrando que arte também significa pesquisa, construção estética, criatividade, ou seja, dá trabalho!

Participando, recentemente, de um evento de contadores de histórias, confesso ter ficado incomodada com a falta de competência de alguns contadores que se apresentaram. $O$ incômodo oscilava entre a incompreensão da história, que não capturou minha atenção ou interesse e, ao mesmo tempo, vergonha pela contadora, me distanciando do texto que ela contava. A falta de interação entre plateia e contador podia ser observada no comportamento agitado dos ouvintes, que ficaram irrequietos, fazendo comentários que provocavam burburinhos, atrapalhando, ainda mais, o ambiente e a contação. Concordo, neste sentido, com a explicação de Cléo Busatto:

A contação de histórias é uma via de mão tripla conduzida pelas intenções. $\mathrm{O}$ que o conto quer dizer; o que o contador quer dizer narrando o conto; o que o ouvinte quer dizer a si mesmo ao ouvir o conto. Narrado, narrador e 
ouvinte: três momentos de um mesmo jogo de encantamento e prazer (2006, p. 76).

E é neste momento triplo de presença que a magia do contador envolve seu público, conduzindo-o ao espaço dos significados.

Neste mesmo evento mencionado no exemplo anterior, em outro momento, com outro contador, se escutava até a respiração dos presentes, em uma atenção que unificava a todos, emocionando visivelmente a plateia. A diferença é marcante quando um contador domina seu texto e seus recursos orais, sem se deixar interromper por um espirro da plateia, ou por um barulho externo, utilizando sua habilidade de improvisação para envolver qualquer acontecimento, em sua narrativa, sem perder o fio da história. Laura Simms, ao relatar sua experiência de contadora, observa o envolvimento dos ouvintes:

\begin{abstract}
Uma história não é uma explicação. Ela é vivida entre quem conta e quem ouve; seu eco ressoa muito além de seu conteúdo. (...) O significado e o poder da história não se encontram só no conteúdo; ao contrário eles se desdobram ao longo dos processos dinâmicos de ouvir e recriar (SIMMS, 2004, p. 60).
\end{abstract}

Não é preciso ser especialista nem crítico em literatura oral e literária para perceber as competências de uma contação de histórias, basta ser ouvinte e ficar encantado. Se o contador tiver conhecimento, saberá escolher seu texto e aproveitar os recursos corporais de que dispõe para cada narração, se fazendo presente na comunhão do conto.

Certa vez, em outro evento, tivemos uma queda de energia, no meio de uma sessão de histórias para uma grande plateia, que justificava o uso de microfone. No meio da história a contadora percebendo o acontecido, improvisou um novo contexto, dando continuidade à história, mesmo sem o uso do microfone. E nessa continuidade, a cumplicidade conquistada pelo contador se encarregou de fazer sua voz $^{75}$ alcançar todo o público, por todo o espaço.

Tierno (2010), refletindo sobre sua prática de contador de histórias e formação de narradores, deixa "pegadas" para marcar os elementos que constituem o que ele se refere à performance do contador. Uma dessas pegadas é o início do complexo processo de alteridade. Para mim, uma das questões bastante sérias no

\footnotetext{
${ }^{75}$ Percebo este fato, não de forma isolada, mas na complexidade de componentes que o envolvem, admitindo ser possível a construção de técnicas que interfiram nesse processo, apontadas no último capítulo.
} 
mundo atual, verificada na falta de percepção do outro na vida social, podendo ser dissolvidos no momento da interação entre contador e ouvinte.

O contato com o outro fortalece a ambos, por serem trocas e experiências proporcionadas pela viagem do conto, como revela Ortiz: "Os contos são uma viagem pelo mundo interior da pessoa, e cada conto traz consigo um fragmento do grande espelho que é a vida" (2004, p. 105). O autoconhecimento propiciado por essa viagem ao mundo interior mostra o poder das histórias em sua capacidade de fortalecimento do ser, em termos emocionais e cognitivos.

Ao ouvir as histórias de seus próprios alunos, a diversidade cultural, certamente, se evidenciará em sala de aula. Nesse sentido, lembro que a perspectiva da construção do narrador oral, aqui presente, não diferencia professores e alunos da escola de ensino regular, embora reserve parte do foco para essas instituições. Prefiro acreditar que todos estariam se construindo contadores, no espaço de troca e transformação ${ }^{76}$, ainda que ampliando papeis, ora de ouvinte, ora de contador.

A escola carece de reconhecimento e valorização da oralidade. "A arte de narrar não está confinada nos livros, seu veio épico é oral. $O$ narrador tira o que narra da própria experiência e a transforma em experiência dos que o escutam" (BOSI, apud JOSÉ, 2012). Conhecer e contar as próprias histórias pode ser de grande ajuda para que os alunos se identifiquem e conheçam realidades diferentes das suas.

Cléo Busatto explica como as histórias operam na construção da identidade, de ouvintes e contadores:

\begin{abstract}
A narração oral de histórias não deveria jamais perder a condição primeira dessa antiga arte, que é funcionar como uma ponte entre as diferentes realidades. (...) Acredito que não se deveria perder a referência da narração e do conto simbólico como mediador entre real e sonho, natureza e cultura, consciente e inconsciente, funcionando como força unificadora e fazendo a síntese das experiências humanas (BUSATTO, 2006, p. 83).
\end{abstract}

Nesse sentido, acredito que contar histórias é uma arte. Uma construção oral, com estética e conteúdos próprios, que se complementam na significação do ouvinte, com alcance diferenciado pela presença do narrador oral, justificando a importância das histórias para a formação do 'ser humano'. Nas palavras de Bia

\footnotetext{
${ }^{76}$ Transformação referente ao conceito de educação desenvolvido no primeiro capítulo, entendendo-a como necessidade humana, acontecendo em vários espaços e de várias formas.
} 
Bedran, encontro a urgência das reivindicações por mais oportunidades de vivências e experiências com arte, para uma construção crítica da realidade:

\begin{abstract}
A arte nos dá um olhar diferenciado ao que se nos apresenta em bombardeio diário pelos meios de comunicação. Ela nos propicia um olhar crítico para esse mundo moderno impregnado das necessidades fabricadas pela sociedade de consumo e distantes das necessidades essenciais do indivíduo (BEDRAN, 2011, p. 62).
\end{abstract}

A construção do contador de histórias, apontada neste estudo, trabalha na perspectiva de que cada um carece encontrar seu próprio caminho, aquilo que o toca de maneira especial, para entender o que é ser tocado por uma história, sobretudo, quando se trata da narrativa tradicional.

Girardello (2004) conta sua experiência com uma contadora italiana que, depois de fornecer várias indicações teóricas em sua palestra, diz que o mais importante de tudo (apagando as muitas referências escritas numa 'lousa') "era o "borbulhar" do encontro!" Ela se referia ao encontro do contador com seus ouvintes, essa presença ancestral, que nasce com cada um de nós. Comparo ao "virar os olhos", identificado por Regina Machado (2004a.), como, capacidade de brincar livremente com a história. Essas identificações do "borbulhar" e do "virar os olhos", sentimentos da interioridade de cada um, são processos artísticos, construídos com o incentivo para que a presença do contador de histórias se efetive, estabelecendo a cumplicidade no compartilhar da história.

Saber o que dizer e o que fazer, para que a história se mantenha e chegue ao seu final é um compromisso sério de um contador que iniciou uma narração. Não se para uma história no meio, a não ser que a criança caia em sono profundo e pergunte, no dia seguinte, o que aconteceu. A história, então, continua, para que a memória não se perca.

A ética do narrador oral envolve responsabilidades com a história, os outros, que são ouvintes, consigo mesmo e com a arte e o ofício de narrar. O compromisso com a história é referente à sua tradição, o que vale a pena perpetuar e o que vale a pena modificar e, isso depende das intenções mais profundas do contador. Nos contos recolhidos na pesquisa em Pirenópolis, citada nos capítulos anteriores, por exemplo, fui questionada, certa vez, por fazer alterações, contando diferente da versão do contador que teria me ensinado aquela história: _ "Então professora, 
como fica a questão da fidelidade com a história, uma vez que você até faz questão de dizer o nome de quem te ensinou a contar e conta diferente?"

Uma resposta única indicaria um modelo que, desde o início, estamos recusando. Então, a resposta vai depender do ponto a ser refletido, com as intenções e objetivos do contador, em suas funções sociais, culturais e educativas. Nos contos recolhidos em Pirenópolis, os personagens antagonistas eram quase sempre negros, revelando os preconceitos raciais cristalizados e ainda presentes em nossa sociedade que, atualmente, são considerados crime. Ora, se os preconceitos precisam ser combatidos, o contador assume essa responsabilidade, pois sua função é cultural e social e o resultado de sua escolha, certamente, influenciará nas consequências. Há locais em que uma discussão não tem espaço garantido e, ao mesmo tempo, sei da influência educativa que o conto exerce sobre as pessoas. Assim, ao contar uma história, tomo o cuidado de não perpetuar valores excludentes e me sinto totalmente à vontade para alterar a característica do personagem em questão. Safia me ensinou: "Aí tinha um negão lá, ladrão né?". Então, eu reconto: "Aí tinha um homão lá né, e ele era ladrão." Assim, a essência da história permanece, sem levantar questões que não tem nada haver com o entendimento da história, mas, que podem, inclusive, se permanecerem, incomodar, a ponto de chamar mais atenção para o preconceito, desviando os conteúdos e riquezas de entendimento que a história traria.

Ao mesmo tempo, para a turma de arquitetos que questionou, considero que o registro da fonte, sim, é um documento, preservo a forma que conheci e registrei a história. Enquanto contadora e divulgadora da obra, reconto da forma que acredito contribuir para a construção de uma sociedade mais justa, sendo esta, uma escolha pessoal, em um conto que é popular.

Concordo com a ideia de que: "Existe, assim, um equilíbrio que cada um há de encontrar entre o respeito ao legado que recebemos dos nossos antepassados e suas possibilidades de evolução" (ORTIZ, 2004, p. 106). Esse equilíbrio pode ser encontrado pelo contador, quando ele repete as perguntas do educador, tratadas no primeiro capítulo: Que sociedade eu tenho? Que sociedade eu quero formar? Isto é, quando ele assume a responsabilidade da consequência de suas escolhas.

Como nas palavras do poeta Elias José: "Eu fico torcendo para cada casa, em cada escola os meninos tenham espaço para serem ouvidos" (JOSÉ, 2012, p. 40). Comparo o desejo do poeta Elias José com os ensinamentos de Paulo Freire, de 
que ninguém aprende sozinho, e sim, "mediado" pelo mundo, neste caso, pelas histórias dos contadores. E também, que a aprendizagem se inicia com a dúvida e o interesse, portanto, ao abrir-se espaço para a fala dos alunos, está se abrindo espaços para aprendizagens múltiplas.

Então, "que venham as experiências de ouvir, de contar, de ler e de viver as histórias, para tudo se recriar, permanecendo!" (PIACENTINI, 2004, p. 101). Considerando, ainda, a importância do que nos diz Estrella Ortiz, para que possamos "respeitar as pessoas que o estão escutando, sem abusar do poder que Ihe confere sua situação privilegiada. (...) Ter cuidado com seu ofício o leva a se responsabilizar pela linguagem que utiliza" (ORTIZ, 2004, p. 109). A responsabilidade está intimamente ligada às imagens e emoções suscitadas pelo conto, por meio da memória e espontaneidade do contador. Dessa forma, com foco nos aspectos que envolvem o compartilhar das histórias, passo a investigar essas relações com a presença do narrador oral.

O compartilhar de experiências, tanto no ato de narrar e ouvir, quanto em sala de aula, despertando novos contadores, pertence ao princípio metodológico que apoia meu ofício de docente e de narradora, no diálogo construído com as experiências dos envolvidos. Assim, procuro entender esses quatro elementos que compõem a presença de um contador: memória, imaginário, emoção e espontaneidade, nos diálogos entre as experiências de quem conta e analisa suas experiências. Portanto, os autores nos quais procuro apoio teórico para refletir e dialogar com minha experiência, são, preferencialmente, os contadores de histórias, que registraram suas vivências.

\subsection{A memória: dos contadores e das histórias.}

Embora nenhum de nós vá viver para sempre, as histórias conseguem...

Bia Bedran

A memória da humanidade sobrevive há milênios de anos, por meio de seu enorme universo de contos, que perpassam gerações, perpetuando e renovando tradições, com a influência de novos tempos. Como diz Tânia Piacentini: "Benditos 
escritores que fazem sua parte na corrente da memória coletiva, registrando, recriando, inventando e despertando outros contadores que as repassam "de boca" ou em outros livros" (2004, p. 99), permitindo que as histórias possam viver para sempre!

Trazer a memória como primeiro elemento para o diálogo proposto, com vista ao entendimento da presença do narrador oral, no momento de sua ação, significa considerá-la inseparável da narração, com tudo que a envolve, imaginação, emoção e espontaneidade, pois é por meio da memória que o conto se presentifica na voz do contador. É preciso deixar claro que, esses elementos que colaboram para a construção da presença do contador de histórias, não existem de forma isolada e, a razão de apresentá-los, em itens, se justifica pela possibilidade de aprofundamento na análise e reflexão de cada componente, contradição inerente ao método escolhido e à organização de mundo em que acredito. Portanto, não existe uma hierarquia de importância entre a discussão que se segue.

Inspirada pela leitura da tese de Girardello, encontrei motivação e conteúdo para o diálogo com outros autores, sobre as relações entre memória e contador de histórias. "A musa inspiradora da invenção poética é, ela própria, filha da memória" (MENESES apud GIRARDELLO, 1998, p. 65). Por isso, memória, arte e tradição são interconectadas, desde sempre, em sua ancestralidade. "A arte de contar histórias é também uma arte da memória. (...) Apresenta-se como um exercício social de oralidade que reviva e atualiza a memória social" (GOMES, 2012, p. 23). Como diz Elias José (2012), os contadores de histórias puderam existir até hoje, graças à memória, que mantém viva nossas tradições orais, nas cantigas, parlendas, charadas e adivinhas, contos, mitos, lendas, fábulas e outros gêneros narrativos, que de forma poética fazem as palavras dançarem, brincarem e invadirem os sentidos dos ouvintes.

Gosto da ideia que Girardello, em texto mais recente, traz do poeta e pedagogo russo, Kornei ChuKovsky, de que há quase um século

(...) em que tendemos a contar às nossas crianças histórias, poemas e cantigas que mais nos tocaram quando nós próprios éramos crianças. $E$ que só ficaram na memória os textos que tinham algo de especial, engenhoso ou profundo. (...) Quem escolhe as histórias para as crianças de hoje são as crianças de ontem! (GIRARDELLO, 2012, p. 42). 
Essa ideia sugere que nossa memória seja capaz de guardar aquilo que nos afeta, nos toca, nos emociona de alguma forma. Segundo Eliana Yunes (YUNES, 2012), envolve aquilo que é guardado de cor! Isto é, no coração, pois se refere a comunidades que não possuem escrita" ${ }^{77}$. "O contador de histórias desenha um caminho que vai dar no coração de quem escuta" (MENDES, 2011, p. 204). E Cleo Busatto complementa com um pensamento Yanomami: "Os brancos desenham suas palavras porque seu pensamento é cheio de esquecimentos" (BUSATTO, 2006, p. 10). Diferente daquelas culturas, nós, da cultura letrada, estruturamos o pensamento recorrendo a registros que, de certa forma, substituem a memória.

A invenção da escrita afeta a estrutura do pensamento organiza um modo de pensar racional que, lentamente, desqualifica o que não é dedutível pelo próprio verbo. A experiência do poiético, do místico e do afetivo foi ao longo dos últimos séculos, cartesianamente mimetizada (YUNES, 2012, p. 62).

Daí a dificuldade em colocar voz na palavra escrita, ela está distante, nos dias atuais, da oralidade e da memória coletiva, que contribui para sua compreensão. Por isso, é tão difícil achar quem saiba ler em voz alta, de maneira clara, compreensível e atraente ao ouvinte.

Se as histórias conseguem sobreviver a tantas gerações, revelando o poder da memória das comunidades que mantiveram acesas as fogueiras dos contos, 0 que responder aos obstáculos identificados, na maioria dos cursos que participei, como mediadora ou aluna, em relação à reclamação da falta de memória, para contar uma história? Persiste a corriqueira a reivindicação dos alunos, em relação a exercícios para a memória: "Como faço para decorar uma história?" "Tem mesmo que decorar?" "Temos de memorizar ou decorar uma história?" E segue-se, contraditoriamente, uma lista com "lembranças de esquecimentos"! Em sua maioria, queixas referentes a distrações que fazem parte do cotidiano de qualquer pessoa, inclusive da vida diária do próprio contador. As dúvidas problematizam, além do mecanismo de funcionamento da memória, a necessidade de esclarecimentos quanto ao decorar e/ou memorizar uma história para ser contada.

Segundo os autores Fox e Girardello, "A noção de decorar um texto completo vai contra a ideia de que as histórias precisam de espaço para se expandirem (ou se

\footnotetext{
${ }^{77} \mathrm{O}$ conceito de oralidade aqui presente será aprofundado no próximo capítulo, quando será discutida a formação do repertório, que pode incluir tanto as histórias dos livros, como as histórias de boca (pertencentes à oralidade).
} 
construírem) em seu contato único com cada plateia específica" (2004, p. 146). Outros contadores adeptos dessa ideia:

\begin{abstract}
Depois de pronto, o resumo poderá ser lido e relido, estudado, mas não decorado. A memorização dele se dará na medida em que você sinta que o enredo pode ser lembrado e contado com suas próprias palavras, como se você tivesse visto a história acontecer. O próprio ato de escrever o roteiro e o resumo é em si o exercício de memorização de uma das técnicas (MORAES, 2012, p. 71).
\end{abstract}

Geralmente, aqueles contadores cuja opção de repertório se enraízam nos contos tradicionais, ligados à oralidade e a uma ancestralidade, preferem preservar esses traços característicos do gênero, optando pela memorização.

Cleo Busatto descreve o contador tradicional, cuentero popular na América Latina, como "um comunicador que adquiriu o dom de narrar influenciado pelo meio que habita, transformando-se na memória coletiva da sua comunidade e transmitindo, por meio dos contos, lendas e mitos, as raízes culturais de seu povo" (2006, p. 19). Assim se constitui e se mantém a cultura de um povo. Complementando essa ideia, Elias José diz que "o sentido de memória cultural está nesse poder de criar, repensar, modificar e atualizar os espaços e as tradições. São esses elementos uma constante na vida humana, logo, em nossas memórias" (JOSÉ, 2012, p. 11). O autor explica que os homens vivem sempre em sociedade, interagindo uns com os outros, produzindo uma soma de memórias que constroem a memória coletiva ou cultural: "A memória possibilita ao homem a noção de identidade e o reconhecimento como parte de um grupo, de uma sociedade que está sempre em mudança" (ibidem, p. 11). Ao rememorar algo, o ser humano tem a chance de refletir sobre sua trajetória e realizar transformações.

Assim, foi se constituindo a memória de cada comunidade, explicada por Ramalho: "As narrativas míticas ajudam a compreender uma sociedade, trazendo sua visão sobre a ordem do mundo, suas regras de convívio - o que não só fortalece seu sentido de grupo, como carrega a sua memória" (2012, p. 28). No meu entender, essa memória de um grupo, ou memória cultural elucidada por Elias José, é "a soma das minhas memórias com as suas é o que vai nos caracterizar como indivíduos. A soma de memórias de uma terra é o que chamamos de memória cultural" (2012, p. 10). É a participação do ser humano em sociedade, o viver e compartilhar dos mesmos interesses, em busca de novos saberes. "A vida dá ao 
homem a oportunidade de mudar os caminhos de sua história e de contribuir para mudanças da história do mundo, quando colabora na construção da cultura, alargando o saber" (ibidem, p. 16). E contar e ouvir histórias é uma das contribuições para ampliação da memória coletiva.

A ampliação do repertório cultural (que considero a memória cultural) constitui a criação de referenciais importantes ao desenvolvimento subjetivo e o incentivo à imaginação e à leitura, como contribuições inerentes ao ato de contar e ouvir histórias, observadas por Girardello (2014). Ainda que a autora se refira à contação de histórias para crianças, amplio a dimensão de sua leitura, considerando-a extensiva a qualquer idade, uma vez que as experiências que analiso, não só incluem qualquer tipo de plateia, como também acredito que a criança que fomos no passado habita cada um de nós no presente, fazendo parte de mim, do que fui e do que sou. O período da infância, embora vivido nos primeiros anos, acompanha o ser humano em seu desenvolvimento de forma latente, assim como muitas de suas experiências. Ficam guardadas na memória, e quando se acha a "chave", aparece a oportunidade de reviver experiências anteriores, da infância ou da juventude, que se renovam quando viram histórias. A "chave”, metáfora que inspirou Girardello (2004), é um dos 'gatilhos' ou 'impulsos' para o despertar de lembranças e histórias.

Observando idosos em oficinas de narração oral, Vera Brandão explica que "as lembranças se apresentam de forma descontínua e mais ou menos profundas, mas nada se perde", (apud JOSÉ, 2012, p. 13), o que leva à compreensão de que, o tempo mítico, interior da memória:

\footnotetext{
vive nas lembranças de modo fragmentado, também assim são nossas lembranças, sem uma lógica temporal. (...) Contudo, são os acontecimentos mais ou menos parecidos do nosso dia - hoje que nos provam a memória e nos levam para o ontem. Aí percebemos que o vivido não se perdeu. Ele volta sempre mais vivo, embora de modo a pedir de quem nos ouve, e de nós mesmos, uma organização temporal inteligível (JOSÉ, 2012, p. 12).
}

Essa reorganização temporal pode levar a identificações do ontem e do hoje nas comparações com seus próprios conhecimentos. Muitos autores consideram que memória é história, e de fato, hoje, a área da história oral reconhece e valoriza um terreno fértil de conhecimento de indivíduos e sociedades. "Se a memória está relacionada e depende da vida entre pessoas, em um tempo e espaço, a cultura também acompanha, passo a passo cada instante revivido no hoje, mas com todos 
os traços do ontem" (JOSÉ, 2012, p. 25). As histórias participam e revelam essas transformações culturais.

Com exemplos de poetas como Manuel Bandeira, Carlos Drummond de Andrade e Cora Coralina, Elias José (2012) leva seu leitor a perceber a vida dos autores em seus poemas. "Através da memória, o homem se situa, se lembra e se conhece melhor. Vive dentro dele as muitas vidas que viveu. Vivem com ele as pessoas e as coisas que fizeram parte do seu universo místico" (JOSÉ, 2012, p. 38).

O movimento de distanciamento (no ontem) e aproximação (do presente), vislumbrado na fala do autor, evoca o entendimento do tempo em sua complexidade e subjetividade. "A memória imaginante viabiliza o passado para sua utilização no presente" (GIRARDELLO, 1998, p. 24) e, essa associação à imaginação feita por Girardello pode, ainda, ser ampliada para a criatividade fornecida pelos dois componentes.

Fabiano Moraes demonstra concordância com este pensamento ao afirmar que: "Memorização e criatividade correspondem de certo modo, à lembrança do passado e a reinvenção do presente. Ao mesmo tempo que rememoramos, criamos" (MORAES, 2012, p. 53). A criatividade sugerida pelo autor se encontra no poder de recriar a história escolhida, com base no profundo conhecimento daquela história e de si mesmo. Nesse sentido, Elias José explica:

\footnotetext{
Memória e palavra no fundo são inseparáveis, são a condição de possibilidade do tempo reversível. Eu me lembro do que não vi porque me contaram. Ao lembrar, reatualizo o passado, vejo, "historio" o que os outros viram e testemunharam (2012, p. 13).
}

Como contadora, sou capaz de recriar a história, modificando-a de acordo com minhas lembranças, que, por sua vez, são incorporadas em mim, passam a fazer parte de mim, quando encontram ressonâncias com as minhas experiências pessoais. Cleo Busatto revela como isso acontece:

Quanto mais uma imagem é carregada de afetividade, maior é a possibilidade de ela se fixar e permanecer ativa por muito tempo, como memória de algo querido, para reaparecer em outro momento, num devaneio ou num sonho (2006, p. 67).

O contador de histórias é um apaixonado pelas palavras, colecionador de expressões e ideias que se encontram nas trocas de histórias e vão, aos poucos, constituindo seu repertório. Acredito que "a memória é uma organização de ideias, 
impressões, subjetividades, afetos e conhecimentos adquiridos no vivido, na leitura, no imaginado" (FARIAS, 2011, p. 20). Na especificidade do contador de histórias há uma facilidade para organizar as palavras, que são a matéria prima do narrador. Para este, é "a palavra que desperta a memória, reaviva lembranças e afetos, propõe, instiga, efetiva vivências" (BUSATTO, 2011). Por isso, a importância da escolha do repertório ser individual é respeitada, pois as relações de afeto estabelecidas e/ou suscitadas pelo texto facilitam sua memorização.

Para Lenice Gomes "não é difícil perceber que a memória é sempre o reencontro com a tradição" (2012, p. 23). Para a autora, é um exercício social de oralidade que atualiza a memória dos presentes.

Nesse sentido, o contador de histórias é a memória da humanidade, preservada por meio de sua transmissão, por meio do imaginário que constrói. "A reminiscência funda a cadeia da tradição, que transmite os conhecimentos de geração em geração" (BENJAMIN, 1975, p. 211). Entendendo como reminiscência aquilo que é conservado na memória, os contadores de histórias tradicionais são o próprio elo entre passado, presente e futuro, que compõe as narrativas e fundam a reminiscência.

\footnotetext{
Sempre que somos estimulados a ir ao passado, trazemos de volta lembranças que envolvem pessoas, lugares coisas, enfim, tudo o que nos marcou afetivamente. Não controlamos nossas lembranças. (...) O nosso modo de lembra-las não será igual de indivíduo para indivíduo, pois cada um foi marcado por elas de forma diferente, segundo sua visão de mundo e sensibilidade. Assim, para cada ser, são mais fortes as marcas individuais, mas o coletivo não desaparece nunca da lembrança. Assim, a memória é individual e coletiva, tem poderosas influências do que vivemos, como, onde e quando vivemos (JOSÉ, 2012, p. 42).
}

Vez por outra, me percebo comparando trechos de histórias, identificando intertextos, isto é, parte de uma história que encontra referência de outra história. Esse exercício tem fundamento apenas na curiosidade lúdica e na ampliação de conhecimentos de versões de histórias, sem nenhuma intenção de classificar ou identificar alguma origem ou classificação. Gosto de conhecer e comparar detalhes que se diferenciam de uma cultura para outra, ou de um tempo para outro. Gosto de perceber personagens coincidentes, em contextos diferentes. As histórias orais passam a ter outros comportamentos, quando são registradas, porém, antes disso foram tecendo uma grande rede, que se espalhou pelo planeta, como o ser humano, sabe-se lá por que paragens andaram, pararam e contaram, ou não, suas histórias, 
que se misturaram a outras histórias que continuaram a ser espalhadas. Essas memórias são o tesouro da humanidade, que encontram ecos e permanência, nos contadores, em seu mundo interno, ou seja, são partes da memória individual e da memória coletiva, que o pertencem.

Quando contamos ou ouvimos histórias estamos envolvidos com a reminiscência, buscando lembranças de vivências, esquadrinhando os significados envolvidos em seu enredo, associando-os com nossa experiência pessoal, em um movimento de aproximação e distanciamento.

Narrar uma história é um modo de estruturar o mundo em função de nossas ações individuais. Implica um trabalho de organização da memória individual, feito a partir da acumulação e organização de dados de uma experiência não necessariamente vivida, visto que a memória é uma organização de ideias, impressões, subjetividades, afetos e conhecimentos adquiridos no vivido, na leitura, no imaginado (FARIAS, 2011, p. 20).

Quando observamos os aspectos da memória que interferem no trabalho do contador de histórias, percebemos uma ligação interna e afetiva, íntima e diretamente ligada ao interesse pessoal do contador, vinculados à reminiscência, citada por Benjamin (1975). Daí uma das justificativas da importância da escolha do texto pelo gosto pessoal, ou seja, aquele que dá prazer, que emociona o contador, antes de qualquer coisa, mas que, também, ofereça estímulos para criação de imagens, por parte do contador e dos ouvintes.

A narração exige domínio do tempo verbal, por isso, organiza o pensamento, agindo como um elo entre passado e presente, entre o que já existe em cada um e o que passa a existir, por meio do que se ouve e se entende. Com um 'mergulho' nas palavras do contador, o ouvinte se aproxima da narração, construindo seus significados referentes ao que está sendo contado, e ao mesmo tempo, distancia para confrontar os novos dados, reorganizando sua memória individual. Isso significa que a memória dos ouvintes também está envolvida na narração (na interação do contar com).

Além da memória afetiva e subjetiva, considero como aspecto objetivo a capacidade de memorização, ou seja, lembrar-se da forma com que as palavras são ordenadas e significadas, naquele conto. Ao entender como funcionam os mecanismos para colocar a memória em ação, o contador pode criar exercícios para sua prática, lembrando que a ludicidade é um dos fundamentos da prática que acompanha a construção do narrador oral, aqui proposta. 
Para o ator e contador de histórias José Mauro Brant, "A memória (e não só a memorização) age como cocriadora do texto que é incorporado pelo narrador" (2011, p. 69). Com essas ideias, podemos identificar outros autores que defendem o papel de cocriadora, ou de coautoria ${ }^{78}$ daquele que aprecia uma obra de arte, no caso, a narração de uma história, como, por exemplo, Ana Mae Barbosa (2008) e João Francisco Duarte Jr. (1988). Ao estudar o texto escolhido para contar, o contador o apreende, colocando-o, de certa forma, junto às suas experiências vividas, para que fique de mais fácil acesso na memória. Em outras palavras, na insistência de Celso Sisto, em suas oficinas: "O contador de histórias é testemunha ocular daquilo que está narrando". Eu gosto de repetir essa frase e percebo que assumo como minha a história que conto. É acreditando nela que vou conquistar a fé de meus ouvintes, fazendo-os acreditar, como eu de fato acredito. Esta certeza me leva a criar imagens que, por sua vez, ficam gravadas em minha memória, sendo suscitadas na hora da narração, servindo de amparo ao envolvimento do ouvinte na significação das palavras.

A memória parece uma caixinha de surpresa, que quanto mais usamos, mais a descobrimos. Como diz Maria de Lourdes, "O contador é também, em princípio, um grande ouvinte/leitor. Dotado de escuta antena, precisa encontrar ouvidos disponíveis para acolher o legado de sua memória" (SOARES, 2011, p. 220). Essa antena capta os interesses que estão à sua volta, armazenando-os para serem utilizados no momento propício.

Recuperando os conceitos, definições e exemplos das várias memórias envolvidas na narração de histórias, verifico a presença da memória afetiva; memorização; memória coletiva e individual; relação com o tempo; organização do pensamento e das palavras, estruturando as histórias; tradição e reminiscência; formação de imagens para o exercício de memorização.

Como o foco na memorização, que atende aos anseios dos aprendizes de contadores, aceito o conceito investigado por Elias José, que recorre à neurolinguística para o entendimento do funcionamento da memória, afirmando ser esta: "a aquisição, a conservação e a evocação de informações. A aquisição se denomina também aprendizado, a evocação também se denomina recordação ou lembrança" (JOSÉ, 2012, p. 10). Entendo-as aplicadas ao contador, associando a aquisç̧ão na

\footnotetext{
${ }^{78}$ Conceito explicitado no primeiro capítulo.
} 
preparação do conto, conhecendo-o e fazendo associações; conservação na repetição do que se quer guardar; e evocação na atenção de conseguir expor aquilo que está na memória.

De forma análoga, exponho a análise de um jogo que aprendi em minha casa (jogando-o quase que diariamente, durante a infância e a adolescência), aplicandoo, também, em sala de aula, colecionando respostas muito semelhantes, ao longo dos anos. Comecei a usar o jogo em oficinas, discutindo o resultado prático com os alunos, na explicação do funcionamento da memorização. A descrição do jogo poderá mostrar detalhes do experimento: é um jogo cumulativo de repetição e associação de palavras.

O jogo consiste, basicamente, em repetir todas as palavras que já foram ditas acrescentando uma última palavra relacionada à anterior. Como é um jogo de memória, quem conseguir dizer maior número de palavras, na ordem em que foram apresentadas, poderá vencer o jogo ${ }^{79}$, se assim for determinado. Ou, o jogo pode acabar em um tempo determinado, dando nova chance aos que não conseguiram da $1^{\underline{a}}$ vez. Quem erra fica com um apelido, mas, mantendo a atenção no jogo, pois este jogador poderá, ao final, tentar novamente (falar as palavras em sequência) com a intenção de se livrar do apelido ${ }^{80}$. Em muitos anos de jogo, sempre foi possível tirar o apelido daqueles que erravam da $1^{\underline{a}}$ vez e recuperavam as palavras, numa segunda chance. Acredito que isso é possível pelo aumento da atenção e da repetição, inerentes ao jogo.

Explico melhor o funcionamento: com os participantes em círculo ${ }^{81}$, um por vez repete as palavras anteriores acrescentando 'a sua', que deve ser associada, sempre, à última palavra que foi falada. É importante que seja jogado em círculo, pois todos acompanham a vez de cada participante e isso faz com que, cada jogador que esteja com a atenção focada no jogo, repita, mentalmente, todas as palavras, aumentando a lista e passando a vez. Quem erra, por não se lembrar de uma palavra, trocar a ordem das palavras, ou se demorar muito, quebrando o ritmo

\footnotetext{
${ }^{79}$ É um jogo simples de acumular palavras, conhecido e reinventado por cada mediador, com base em seus objetivos e possibilidades, e regras locais ou reinventadas.

${ }^{80} \mathrm{~A}$ ideia de evitar regras de eliminação nos jogos, transforma-se de forma que o jogador possa continuar na brincadeira, ainda que com papel diferente. É uma herança dos tempos de Educação Física, com os Jogos Cooperativos (que levam em conta uma época de inclusão).

${ }^{81}$ Quanto mais participantes melhor. Já fiz até com turma de 50 alunos; quando são em menor número, como era no almoço em nossa casa, eram jogadas em várias rodadas seguidas. Era ótimo ter gente de fora e ensinar a brincadeira, mas difícil acompanhar a performance da família, que era bem treinada, pela repetição cotidiana.
} 
da brincadeira, ganha o apelido de "burro 1", ou outro apelido ${ }^{82}$ (mais moderno). segundo a errar fica com o apelido de "burro 2" e, assim por diante, sendo que este nome é incluído no lugar da palavra que aquele participante deveria ter acrescentado. Lembrando que, ao final terão chance de tirar o apelido, dando nova chance à sua memória. A constância de coincidências durante o jogo, em mais de vinte anos, me permitem algumas afirmações sobre o funcionamento da memória, que encontra eco no conceito explicitado anteriormente. A primeira observação é de que todos os participantes do jogo conseguiam a retirada do apelido, possível pelo aumento da atenção e número de repetições, ao longo da brincadeira.

Ao considerar a "aquisição" como componente indispensável à memória, constato como sinônimos: obtenção e cognição, ou seja, é aquilo que fica retido ou incorporado ao sujeito, guardado para ser acessado, quando solicitado. No jogo anterior, são as palavras obedecendo à uma ordem determinada. É um momento de aprendizagem que se dá via memória, porque as novas informações entram em contato com as informações anteriores, se complementando e se modificando ${ }^{83}$. $O$ conhecimento adquirido é, então, "conservado", para ser lembrado quando acionado, sendo a lembrança uma forma de evocação, no conceito proposto. O que é conservado depende do grau de interesse, afeto e os significados subjetivos envolvidos.

Assim, o trabalho do contador está em construir técnicas para conservar aquilo que lhe interessa, por meio de formas (gatilhos) para provocar as lembranças da história a ser contada. $O$ interesse pessoal amplia as possibilidades para exercícios de associação, uma vez que a afetividade está diretamente envolvida. A memória está, também, diretamente ligada à atenção, pois se desviamos o pensamento por fração de segundo que seja, durante um exercício ou durante uma narração, corremos o risco de esquecer, ou se perder no texto. Ainda em relação ao exemplo do jogo, posso afirmar que, quando alguém erra, ganhando o apelido, mais tarde consegue, com facilidade, superar a quantidade de palavras ditas na primeira vez. Isto se dá, em primeiro lugar, pela atenção que foi aumentada, por parte de

\footnotetext{
${ }^{82} \mathrm{Em}$ apenas duas ocasiões esse apelido foi questionado e pedido para ser modificado. Particularmente, entendo que o uso do apelido de "burro", na brincadeira, pode ter sido criado justamente para levantar discussões sobre os significados e atitudes dos professores, que achavam pertinente usar um chapéu de burro no aluno que cometesse um "erro". No início da minha experiência docente (1976), esse procedimento ainda era utilizado, com certa frequência, sobretudo, no interior de Goiás.

${ }^{83}$ Explicação que se aplica às teorias sócio interacionistas ou construtivistas do ensino/aprendizagem, em que se apoia minha prática docente.
} 
quem está no jogo. E, em segundo lugar, pela repetição, originada pela regra do jogo, que ajuda a fixar o conteúdo na memória.

Nas observações registradas ao longo dos anos, observo que as formas de associação são pessoais, de acordo com as experiências de cada um. Por esse motivo, nem sempre havia concordância na associação de determinada palavra. Quando isso acontecia, a dificuldade de entender a associação da nova palavra proposta, com a anterior, resultava em "erro" (esquecimento da palavra falada e afastamento da memória). Um exemplo prático pode ilustrar essa situação, esclarecendo-a melhor - o jogo está em andamento, com as palavras: caderno; caneta; carta; amor; coração; vermelho; sangue; vampiro; dentista; dor. O próximo a jogar é filho de dentista e não consegue entender o que "dor" tem haver com a palavra dentista, que para ele é sinônimo de segurança e conforto, sem qualquer tipo de dor. No calor do jogo, não há espaço para discussões sobre o que pode e o que não pode. Levando em consideração que cada um faz suas associações de forma pessoal, essa é uma das dificuldades que coloca dinâmica enquanto se joga. Esse último jogador sentia uma enorme dificuldade de lembrar-se dessa passagem: dentista; dor. Isto se dá pela existência simultânea da memória coletiva e individual. Com o tempo de experiência, eu sabia onde aconteceria a maior parte dos "esquecimentos" em uma roda, mostrando aos participantes detalhes que escapavam à sua atenção, associação ou repetição.

A sensação que tenho, vinda dessa experiência de tantos anos, é de que quanto mais exercitada a memória, mais viva e em bom estado de funcionamento ela permanece. Sobre técnicas e exercícios para memória encontramos, desde a mais antiga e ainda eficiente forma de decorar um texto pela repetição, por partes, de preferência em voz alta, até que seja internalizado, até formas divertidas e diferentes jogos que envolvem os aspectos levantados.

$\mathrm{Na}$ experiência de Gilka Girardello, em vinte anos trabalhando em oficinas de formação de narradores, abre-se espaço para um exercício de afeto e memória, por achar-se que é a "forma de evocar o fio narrativo que une as gerações humanas em laços de sentido" (GIRARDELLO, 2012, p. 42). E ela tem razão! O fio narrativo puxado pela memória é o que nos une, nos chama, nos enfeitiça e faz querer mais, querer ouvir mais e ter mais oportunidade de contar. "É um engano e um preconceito sem tamanho, achar que memória é coisa de velho. Basta ter vivido para termos histórias a serem contadas" (JOSÉ, 2012, p. 43). Nos piqueniques que tive 
oportunidade de participar, promovidos por mim, por minha orientadora Luciana Hartmann, ou por outras pessoas, experimentei sensação semelhante.

A afirmação de Walter Benjamin de que "a relação ingênua entre ouvinte e narrador é dominada pelo interesse em conservar o que é narrado" (1975, p. 210), evidencia que a própria relação entre contador e ouvinte pressupõe o exercício da memória de ambos. Nas rodas de histórias, percebemos como uma história puxa a lembrança de outra história, seja pela semelhança do início, do fim, de algum personagem, ou de uma situação análoga experimentada em outro conto.

Giuliano Tierno (2010) relaciona memória e imaginário em solidariedade, apontando-a como a "primeira pegada" do contador de histórias a ser seguida por quem quer aprender a contar. "Imaginação é um exercício contínuo de formação de repertório e conexão de pensamentos "em fortalecimento" articulatório para que seja possível, de fato, este diálogo solidário com a memória, com nossas reminiscências" (TIERNO, 2010, p. 17). Em minha experiência, vejo que guardo mais facilmente em minha memória as partes da história em que a imagem é bem construída, ou seja, é nítida, clara, por isso, fácil de entender e de lembrar. Assim, o meu primeiro exercício de memória é construir a imagem do que quero guardar, uma imagem real, com detalhes que, nem sempre, são claros ou explícitos na narração.

\title{
3.2. O mundo imaginário dos contadores.
}

\author{
O olho vê \\ A lembrança revê \\ A imaginação transvê. \\ É preciso transver o mundo. \\ Manoel de Barros
}

Uma característica comum aos narradores, de ontem e de hoje, é a capacidade que têm de suscitar imagens daquilo que está sendo narrado. $\mathrm{O}$ contador de histórias de hoje, aprende dispositivos para que as imagens sejam construídas pelo ouvinte, enquanto narra. Contudo, antes de entender o movimento provocador e gerador das imagens que habitam o mundo das histórias, deparei-me com a figura de um narrador oral descrita por outra contadora, que eu sempre quis 
descrever como minha, embora, na casa de meus avós nunca tenha tido uma cadeira de balanço.

\begin{abstract}
A cena da avó na cadeira de balanço contando antigas histórias para os netinhos é coisa do passado (...) mudaram as famílias e mudaram as avós. Mas, podemos tomar essa imagem de um jeito mais simbólico, mais arquetípico designando todos os adultos que narram experiências de vidas para crianças. E aí a cena pode virar fonte de energia e de inspiração para o trabalho dos contadores de histórias de hoje (GIRARDELLO, 2012, p. 45)
\end{abstract}

Aí está uma elucidação! Talvez, a energia dessa imagem tenha me envolvido nessa magia do contar e ouvir histórias, acabei sendo eu a contadora e avó, embora sem a cadeira. As imagens parecem nos explicar e nos ensinar a aprender o mundo. Em sua tese de doutorado, Girardello (1998) explica que a imaginação, em constante mudança, deforma, mas nunca destrói as imagens. De acordo com as ideias de Benjamin (1975), ainda que não corresponda exatamente ao que acontece no tempo real, servem, no mínimo, de referência. Por isso, são guardadas como fonte de inspiração para outros usos.

Antes de prosseguir com as imagens provocadas pelas histórias, esclareço que considero a distinção entre: imagem, imaginário e imaginação, no âmbito deste estudo, esclarecendo cada um dos termos ao longo do capítulo.

As imagens das histórias são formuladas tanto pelos ouvintes, que acompanham a narração, quanto pelo narrador, que encontra meios de fornecer estímulos à formação de imagens de seu público. Elas foram elaboradas, anteriormente, pelo contador de histórias, no momento do estudo e preparação da história, e são acessadas pelo narrador oral e pelo ouvinte, durante a ação de contar.

\footnotetext{
Narradores e ouvintes trabalham juntos na criação de imagens mentais, levando cada ouvinte a "possuir" a história, a fazê-la sua (...) Não há qualquer oposição ou competição entre histórias contadas e impressas. $O$ amor por ouvir histórias leva as crianças a quererem mais - e mais - histórias (FOX e GIRARDELLO, 2004, p. 127).
}

O contador captura seu ouvinte, envolvendo-o nas imagens suscitadas pelo conto, e é essa capacidade que os atrai. Como diz Busatto: "O narrador lança as imagens no ar e o ouvinte a transforma na sua história, ancorado pelo seu imaginário e pela sua própria história de vida para construir personagens, situações 
e ações" (2011, p. 101). Acreditando nas imagens que vê, o contador fica mais seguro enquanto conta, envolvendo o ouvinte nessa credibilidade. Essa construção da imagem acontece em cada um, de forma distinta, sugerindo investigação e aprofundamento.

Imagem, imaginário e imaginação são palavras que participam ativamente da narração de histórias, embora, não necessariamente, contenham os mesmos significados e usos. Derivam de um mesmo radical grego: icon ou icono, que em nossa língua quer dizer: ícone, sinônimo de imagem.

Tomando emprestadas reflexões sobre a gênese das imagens, Cléo Busatto nota que "o desenho mental é uma forma inicial de apreender o mundo, e que o imaginado é, a um só tempo, dado e construído. Dado enquanto matéria. Construído, enquanto forma para o sujeito" (2011, p. 65). É através e deste complexo universo de imagens construídas, em construção e constante reconstrução, transitado pelo contador e pelo ouvinte de histórias, que busco entendimentos, para a construção da prática de narrar.

Percebo a construção de imagens diretamente relacionada com a cultura, e acolho esta atividade como tipicamente humana. Edgar Morin explica que:

Privado de cultura o sapiens seria um débil mental, incapaz de sobreviver a não ser como um primata do mais baixo nível; nem mesmo poderia reconstituir uma sociedade de complexidade igual a dos babuínos e chipanzés (2000, p. 92).

Para esse autor, o imaginário surge na condição humana, desde os primórdios, pois irrompe na percepção do real e, por meio do mito e da magia, constrói sua visão de mundo e suas formas de vencer. "São imagens mentais que invadem o mundo exterior e é nessa confusão que se constroem o mito e a magia, isto é, organização ideológica e prática da ligação do imaginário com o mundo" (MORIN, 2000, p. 108). O mito e a magia nascem para vencer a desordem entre o real e o imaginário e, é ao que o homem recorre, deliberadamente, na construção de sua cultura e de sua identidade.

Com o tempo e o treino do imaginário, o homem descobriu que era capaz de sonhar, de contar histórias, de cantar a vida, de desenhar, de dançar, enfim de fazer mil coisas mais. (...) O que o homem estava fazendo era, a partir do mundo da natureza, criar o mundo da cultura (JOSÉ, 2012, p. 28). 
Ao considerar essa capacidade de imaginar, como fundamento para construção da presença do narrador, escolho os estudos da tese de Girardello (1998) como referência para o entendimento do imaginário em suas relações com a narrativa, pelo foco da autora nos "laços entre imaginação narrativa presente nas teorias da imaginação" (GIRARDELLO, 1998, p. 5), o que me dá grandes pistas para o entendimento voltado para a ação do contar e ouvir histórias. Sem pretensão de refazer seus caminhos, consagro sua pesquisa, utilizando-a nas referências que ajudam a pensar na ação de contar e ouvir histórias, para a construção de um narrador oral consciente de suas ações.

A primeira observação que chamou minha atenção, na Tese de Girardello (1998), foi o significado escorregadio da palavra imaginação. Em seu estudo, entre as várias áreas que envolvem o tema em questão, o campo da filosofia, para a época em que a investigação, foi realizada, além de maior consistência, ofereceu a história de como o conceito foi desenvolvido, nas ideias de Kearney, um dos autores escolhido por Girardello para historiar o conceito de imaginação.

Passando por diversos status e entendimentos diferentes, em épocas distintas, a imaginação sofreu preconceitos e discriminações. Confirmadas por Busatto "Uma das consequências dessa forma de ver o mundo foi a rejeição dos sonhos, das visões, da fantasia, da alegoria e da imaginação" (2006, p. 51). Esta rejeição, Girardello (1998) explicitou ao levantar a história do conceito de imaginação, revelando seu apelido de a "louca da casa", certa época, suscitando a criação das superstições. As duas autoras reconhecerão as transformações culturais, no século $\mathrm{XX}$, onde o "saber se aproximando de diversos níveis de realidade, reconhecendo o espaço simbólico da vida humana e considerando o papel de mediador do imaginário e das imagens" (BUSATTO, 2006, p. 53), passam a ter algum reconhecimento e importância para o desenvolvimento humano, embora encontre ranços de rejeição ao sonho e à fantasia.

Para Bachelard, "a imaginação é vista como energia organizadora, a imagem surgindo para iluminar a própria imagem” (2000, p. 55). Por exemplo, quando o ouvinte desenha em sua mente a forma de um baú que o viajante carrega, para entender sua dificuldade em arrastá-lo, sem estragos. O que aproxima a narrativa da imaginação, entendida desde Aristóteles (A Poética), "como um movimento psíquico ligado ao desejo, particularmente ao desejo de conhecimento" (GIRARDELLO, 2014, p. 6) é o impulso do ouvinte para acompanhar a história, a fim de saber o que virá 
depois. As crianças e pessoas mais curiosas costumam ir à frente da história, tentando ou adivinhando o que vai acontecer, e isso é um estímulo. Com as outras menos curiosas, o contador estimula com seus recursos, em busca da compreensão do ouvinte.

Criar identificações, formas, contornos e entendimentos múltiplos por meio das imagens que construímos quando ouvimos uma história, caracteriza-se como uma forma de aprendizagem, desde que as imagens construídas tenham significado. Lembro-me, quando pequena, de minha emoção ao descobrir que um "catre", em um Mosteiro das Beneditinas, em Petrópolis, apresentava a imagem formada em minha mente, quando conheci a palavra na leitura de um romance. A imagem formada por mim correspondia ao objeto que acabara de conhecer. O contrário também pode acontecer: não tem muito tempo que eu redescobri o significado da expressão 'pé de cachimbo', da parlenda "hoje é domingo...", que, na verdade é, 'pede cachimbo', do verbo pedir, pois domingo era dia de fumar cachimbo. Pois minha imagem era de um arbusto, cheio de cachimbos pendurados ${ }^{84}$. Concordo com Busatto ao pensar

\begin{abstract}
o imaginário como um vasto campo de possibilidades, que proporciona, entre tantas coisas, a compreensão e a aceitação de diferentes níveis de percepção da realidade, abrindo-se para um sistema participativo, plural, sensível e passível de outras lógicas. (...) Por outro lado, contar histórias pode ser fermento para 0 imaginário. Elas nascem no coração e, poeticamente circulando, se espalham por todos os sentidos, devaneando, gatiando, até chegar ao imaginário. O coração é um grande aliado da imaginação nesse processo de produção de imagens significativas (2006, p. $58 / 59)$.
\end{abstract}

Se entregar ao devaneio poético significa considerar a relação solidária entre imaginação e memória, já citada anteriormente. Esse devaneio, segundo Tierno (2010), é a entrega do contador a um espaço da infância, um local no interior de cada um, seguro, livre de medos, onde há permissão para criar sem limites, lugar íntimo de cada um, espaço de autoconhecimento a ser explorado internamente.

Outro ponto importante abordado por Regina Machado é que "o trabalho com a imaginação pode manter viva a chama da flexibilidade" (MACHADO, 2004a., p. 31). A narração fala a cada um de formas diferentes, penetrando em seu mundo imaginário por meio de afetos, emoções que encontram ressonâncias com as

\footnotetext{
${ }^{84}$ Ao registrar essa observação, verifiquei que a parlenda é grafada: "pé de cachimbo", o que pode ter influenciado em meu entendimento... Ou, ao contrário, confundiu a maioria das pessoas, como aconteceu comigo, inclusive, com quem registrou na escrita.
} 
experiências individuais e coletivas de quem ouve a história. Os contos tradicionais acordam imagens internas em cada um, em contato com a reminiscência, aquilo que afeta e é guardado na memória para ser acessado, quando solicitado.

\begin{abstract}
Quando ouvimos um conto - adulto ou criança -, temos uma experiência singular, única, que particulariza cada um de nós, no instante da narração, uma construção imaginativa que se organiza fora do tempo da história cotidiana, no tempo do "era". Tal experiência diz respeito à universalidade do ser humano e, ao mesmo tempo, à existência pessoal como parte dessa universalidade (MACHADO, 2004a., p. 23).
\end{abstract}

O tempo universal, dentro do conto tradicional, une os ouvintes da história no mundo da fantasia, ou em qualquer tempo garantidamente diferente do tempo presente do relógio. E, ao contrário do que se pensa, hoje os contos de fadas começam a ser reconhecidos em sua importância arquetípica, entre nós contadores de histórias, por teóricos de várias áreas como: psicologia (psicanálise), letras, arte, antropologia, história oral, neurociência e outros. E, apesar de não ser tão aparente, já vi, como Regina, muitos adultos como se estivessem em transe, ouvindo e participando das histórias, com a mesma empolgação das crianças.

Já cansei de ver adultos na plateia torcendo para o jovem herói acertar a flecha no ovo atirado para o alto pelo velho mestre, com gestos aflitos - e OHS! - de admiração, respiração suspensa e risos de alívio, Para aqueles que se esqueceram da maravilha desse tipo de experiência, o "faz de conta" é cuidadosamente esquartejado com as armas da razão, que ilusoriamente o rotula de "infantil", "pueril", "fuga da realidade" e outros tais (MACHADO, 2011, p. 200).

O transportar-se para o lugar onde acontece a narração abre a capacidade de imaginar, ou seja, de formular, criar imagens, com base em uma narrativa. A voz e outros recursos do contador conduzem-nos, de corpo inteiro, para o cenário do conto, onde criamos imagens para cada detalhe, acompanhando as palavras do narrador.

As características ou fórmulas de iniciar e de finalizar os contos tradicionais são apontadas por definirem os espaços imaginários, que pode durar o tempo da narração da história. Alguns autores ${ }^{85}$ apresentam ótimas listas colhidas ao longo de suas experiências, sobretudo na oralidade, que garantem o clima da história em sua abertura e encerramento, o tempo da 'visita' ao imaginário.

\footnotetext{
${ }^{85}$ Regina Machado (2004a.); Gislayne Matos (2006); Cleo Busatto (2006).
} 
O imaginário é um lugar individual, que alguns autores chamam de fantasia, um entre lugar, um espaço etéreo, que dura o tempo da história, nas ideias de Celso Sisto (2012a).

Nos estudos da imaginação, de Girardello (1998), constato o uso dos termos: fantasia, devaneio, imaginação, assim como, na maioria dos estudos dos contadores sobre o tema.

Regina Machado, em busca de fundamentos poéticos para a arte do narrador de contos tradicionais, desvenda o mundo do "era", revelando-o como o espaço para a vivência do imaginário. "Nesse lugar, encontro não o que devo, mas o que posso" (MACHADO, 2004a., p. 24). Sendo um lugar seguro, 'tudo pode'. É seguro por pertencer a um tempo/espaço diferente do real. A possibilidade de um passado existir no presente é possibilitada pelo tempo do "era", para onde somos transportador quando ouvimos uma história, "local desconhecido que se torna imediatamente familiar" (MACHADO, 2004a., p. 23). Concluindo:

\footnotetext{
"Era uma vez" quer dizer que a singularidade do momento da narração unifica o passado mítico - fora do tempo - com o presente único - no tempo - daquela pessoa que a escuta e a presentifica. É a história dessa pessoa que se conta para ela por meio do relato universal (ibidem, p. 23)
}

Por serem subjetivas, as ressonâncias repercutem, universalmente, em quem participa desse momento, e de diferentes formas, nas pessoas, desencadeando efeitos particulares nos ouvintes. Ao mesmo tempo, a objetividade da narração também permite reações semelhantes, portanto, plateia e contador, por vezes, tem a sensação de compactuar de uma mesma imagem, provocada pela narração de uma história. Nesta identificação, intuída por trocas de olhares e/ou expressões do corpo, o contador mais experiente consegue perceber as aproximações e afastamentos de seus ouvintes, elaborando melhor a sua fala, para provocar imagens mais claras.

"O grande trabalho do contador é dizer o texto de forma clara para que ele seja elaborado na imaginação do ouvinte" (PESSOA, 2011, p. 79). Ou seja, o narrador oral elabora suas próprias imagens com base em suas experiências, convidando o ouvinte a participar da narrativa e, também, a construir suas paisagens. A esse envolvimento do contador com o ouvinte, na significação das palavras, ou na produção das imagens, atribuo parte importante da presença do contador, por ser fundamental no contar com. 
Essa realidade é possível porque ouvinte e contador constroem juntos os significados do que está sendo narrado, por meio de imagens internas. Ambos estão mergulhados no ambiente do conto e tudo ali existe e é verdadeiro, naquele momento, embora saibam da existência de uma realidade, fora do conto. O que importa é acompanhar a história, criando as imagens sugeridas, como dizem Fox e Girardello:

\footnotetext{
Narradores e ouvintes trabalham juntos na criação de imagens mentais, levando cada ouvinte a "possuir" a história, a fazê-la sua (...) Não há qualquer oposição ou competição entre histórias contadas e impressas. $O$ amor por ouvir histórias leva as crianças a quererem mais - e mais histórias" (2004, p. 127).
}

Ao escolher os contos tradicionais para seu repertório, Regina Machado, acredita que "As imagens do conto acordam, revelam, alimentam e instigam o universo de imagens internas que, ao longo de sua história, dão forma e sentido às experiências de uma pessoa no mundo" (MACHADO, 2004a., p. 24). São as imagens que possibilitam uma vivência em um mundo diferente do mundo real, em um tempo presente do "era", num espaço construído pelas imagens. A autora continua:

\footnotetext{
Contar histórias e trabalhar com elas como uma atividade em si possibilita um contato com constelações de imagens que revela para quem escuta ou lê a infinita variedade de imagens internas que temos dentro de nós como configurações de experiência (MACHADO, 2004a., p. 27).
}

Por isso, a importância do contato com muitas histórias, seja ouvindo, lendo, recriando, recontando. Afinal, por meio das histórias podemos conhecer tempos e lugares, somente possíveis no mundo imaginário, um espaço de criação tão carente de incentivo nas escolas e no mundo de hoje.

$\mathrm{Na}$ fala de Elias José, o ser humano "constrói cultura, transformando o mundo e a natureza. Assim, é marcado pelo espaço, mas também o marca com a sua criatividade, o seu imaginário, ligado a sua inteligência e sensibilidade" (2012, p. 11). As histórias que ele conta e reconta são o testemunho dessa criatividade.

As pessoas acreditam nas informações e nas imagens divulgadas pela mídia, esquecendo-se que a imagem pode ser inventada, ou construída, para um determinado fim. Isto é explicado por Busatto, que absorve a ideia de Calvino de um mundo saturado de imagens sem significado, que no dizer da autora, contribuem 
mais para a: "poluição dos sentidos e para a construção de ruídos. Se em outros tempos o imaginário era nutrido fundamentalmente pela memória das experiências vividas, hoje convivemos com a indústria de imagens" (BUSATTO, 2006, p. 60), que provocam o simulacro do pensar.

Para Busatto, "O imaginário do século XXI está povoado por armas de destruição em massa, atentados terroristas, assalto à mão armada, imagens da fome e da miséria" (2006, p. 11). Mas, também, por narradores que espalham imagens de: paz, gratidão, partilha, compreensão, bondade, beleza, etc. Regina Machado explica: "A imaginação criadora propicia o exercício do convívio com o inexplicável desconhecido. (...) operando na arte narrativa produz um determinado efeito, produto da arte e do encantamento" (2004a., p. 25). É por acreditar na necessidade de encantar o mundo, contrapondo toda essa desigualdade e destruição, que conto histórias, na intenção de contribuir para a construção de uma cultura da paz e do respeito ao outro.

Buscando Girardello, mais uma vez, entendo que "O fazer narrativo é indissociável do acervo imaginário da cultura. (...) Este acervo é frequentemente descrito como um reservatório de histórias" (GIRARDELLO, 2014, p. 10). Ele coloca em jogo um universo de significações entre imagem e palavra; e entre imaginação e narrativa. Daí a importância de contar e ouvir muitas histórias, como diz Celso Sisto "Salvar o mundo imaginário" (2012a), ameaçado pelos caçadores da Emília ${ }^{86}$, ou daqueles que não aceitam a necessidade da vivência com o imaginário.

Ao contrário do que se apresenta "as crianças podem imaginar muito menos coisas que os adultos, porém creem mais nos frutos de sua fantasia e a controlam menos" (VYGOTSKY, 1987, p. 42). Afirmação aceitável quando se considera que elas não tiveram tempo de experimentar, para enriquecer o repertório. Quanto menor o contato com as possibilidades imagéticas, mais pobres serão as referências do imaginário dessa pessoa. Os autores presentes neste estudo concordam que as histórias são estímulos para o enriquecimento do mundo imaginário, por sua capacidade de suscitar a formação de imagens, daí a importância em apresentar

\footnotetext{
86“Sou a independência ou morte"! Defende a Emília (do Sítio do Pica-pau amarelo), daqueles que querem condenar: cantigas de roda, contos de fadas e toda a sua liberdade. Essa é uma das críticas que Ilan Brenman nos presenteia com sua obra: "A condenação de Emília: o politicamente correto na Literatura infantil". Uma crítica necessária àqueles que querem afastar o mundo imaginário do cotidiano da escola.
} 
possibilidades diversas aos ouvintes, sobretudo em crianças que estão em plena formação de seu desenvolvimento.

"Se as crianças operam com imagens estereotipadas, seu aprendizado será pobre de sentido, de experiência pessoal" (MACHADO, 2004a, p. 32). Entretanto, o perigo do desenraizamento é a alienação. Tenho colegas, hoje, que consideram a Xuxa como 'princesa brasileira'. Até aí posso concordar, porque faz parte de uma longa experiência de sua infância. Mas, daí a continuar ouvindo, valorizando e querendo impingir aos seus alunos como valor artístico, acredito que mais reduz do que amplia o imaginário do aluno. O conto "O menininho", de Millôr Fernandes, ilustra a complexidade e consequência desse tipo de situação. Este é um conto bastante divulgado e conhecido entre os arte-educadores, preocupados com uma educação artística cheia de regras e cópias, sem considerar a criatividade do aluno. Um dia, o aluno do conto cresce, muda de escola e quando the aparece a oportunidade de criar, ele copia o que the foi impingido, desde sempre, na escola anterior que frequentara. Então, 'o menininho' pinta uma flor vermelha com caule verde, como exigiu sua primeira professora.

Concordo com Marie Shedlock (2004, p. 20), quando esta considera a infância e a juventude como a fase de criação de imagens mais intensa, sendo mais propícia a retenção das histórias, justificando sua inclusão nos currículos escolares.

A percepção da importância das histórias no despertar da imaginação é, também, observada por Santos, quando observa que: "Mudaram os tempos, mudaram os costumes, mas as histórias continuam sendo necessárias para despertar a imaginação, criatividade e o gosto pela leitura" $(2004,179)$.

Sérgio Bello demonstra concordar com os outros autores, que, ao invés de desaparecerem, os contadores têm se multiplicado.

\footnotetext{
Efetivamente, vemos e sentimos os acontecimentos de nossa imaginação. Construímos imagens mentais a partir da palavra, escrita num caso, ouvida no outro. Este é o exercício. E aqui percebemos uma relação íntima entre a leitura e a escuta, da mesma forma em que na fala e a escrita. A escuta de histórias, portanto, pode desenvolver a imaginação, e entre outras decorrências disso há uma bastante cara para nós, professores: pode tornar-se um encaminhamento para a construção da leitura (2004, p. 159).
}

Preocupação coerente e necessária ao desenvolvimento do ser humano das sociedades letradas, portanto, nas escolas, independente da área de ensino ou 
atuação, sinto falta de os professores considerarem a escuta e fala tão importantes quanto leituras, nas diversas linguagens.

A definição do termo imaginação, utilizada por Gislayne Matos (2006), a partir de Georges Jean, pertence a uma investigação sobre o contexto do contador de histórias, podendo ser analisada quando aplicada à sua prática.

O termo imaginação designa grosseiramente a faculdade pela qual 0 homem é capaz de reproduzir - em si mesmo ou projetando fora de si - as imagens armazenadas em sua memória (imaginação dita "reprodutora"), e de criar as imagens novas que se materializam (ou não) nas palavras, nos textos, nos gestos, nos objetos, nas obras etc. (JEAN, 1991 apud MATOS, 2006, p. 25).

Chama-me atenção a habilidade de reproduzir e criar imagens que o contador consegue suscitar em si próprio e em seu público. Minha experiência revela que antes da participação do ouvinte, ainda na fase de preparação da história, o contador formula concretamente as imagens da história que está narrando, e isso Ihe dá segurança para suscitar imagens de seus ouvintes.

Para Girardello (1998), imaginação e memória brotam na mesma parte da alma e são capazes de unir passado e futuro, presentificando-o. Essa possibilidade é explicada por Celso Sisto, porque o "tempo do imaginário é outro. É um tempo de suspensão (ou de mergulho), em que tudo fica como que parado ou adquire outros contornos" (2004, p. 87). As histórias trazem elementos da realidade humana, ao mesmo tempo em que trazem noções desconhecidas, que passam a existir porque presentificadas pelo imaginário e imaginação, do contador e do ouvinte, mediante a narração.

Assim, a narrativa atua no plano subjetivo individual, na dimensão do inconsciente. A psicanálise "sistematiza o papel da imaginação e da narrativa na interação subjetiva e na própria formação do sujeito" (GIRARDELLO, 1998, p. 58). Na explicação de Lacan, usando as palavras de Girardello:

O simbólico é o domínio tanto da troca de palavras entre as pessoas como vislumbre do Outro que nos constitui em segredo e que fala através de nossos lapsos, trocadilhos involuntários e outras figuras de linguagem que nos fazem dizer o que não pretendíamos(apud (GIRARDELLO, 1998, p. 31).

Na visão da autora, é a superação da visão romântica e existencialista da imaginação. Entendida no campo das artes, pode abrir novas perspectivas. Para 
Busatto, "Arte é transformação simbólica do mundo". (2006, p. 49). Ideia complementada pelo esclarecimento de Regina Machado, ao reconhecer que a arte: "permite esse trânsito compreensível pelos significados fundamentais da vida humana. (...) Não se trata de uma compreensão mensurável ou explicável dentro dos padrões convencionais" (2004a., p. 25/26).

Os símbolos não se prestam a isso, sua compreensão depende de conhecimentos e experiências anteriores, de sensações e sentimentos internos que não são traduzíveis em palavras. Mas são sentidos na intersubjetividade, assim explicados por Girardello: "O papel da narrativa na intersubjetividade envolve a partilha de imagens. Entre quem conta e quem escuta vibra por instantes a centelha de um sentido comum, no espaço da clareira imaginária, de que fala Ricoeur" (1998, p. 59). Metáfora que a autora tem utilizado para nos envolver em suas trilhas, sempre revisitando e descobrindo novas paisagens, que nos conduzem a refúgios repletos de centelhas, capazes de iluminar e transformar nossa prática de caminhar.

Enquanto conta sua história, o contador a "imagina", ou seja, formula as imagens do conto em sua mente. A ideia viva do conto, em formas, cores e movimentos, como num cinema, auxilia no domínio da narração. Na experiência de Bernardo Zurk:

Uma boa história bem contada é capaz de provocar o imaginário de quem a ouve. É uma possibilidade mágica que o ouvinte tem de operar um filme em seu cérebro por intermédio das imagens que vão sendo provocadas no decorrer do fio da narrativa (2008, p. 119).

Muitos contadores falam desse filme, nos cursos, relatando experiências. Fox e Girardello esclarecem que "esse "filme mental" não é cinema mudo. O contador precisa ouvir a trilha sonora e ajudar os ouvintes a ouvi-la também" (2004, p. 147). Essas imagens devem ocupar toda a extensão do conto, pois constituem um elo entre contador e ouvinte, na medida em que ambos constroem parte do significado da narrativa, por meio das figuras estabelecidas. Deste modo, não é só o contador que se beneficia da formação de imagens durante o conto. Ele espera de sua plateia que esta consiga visualizar, cada um à sua maneira, as imagens que constituem o sentido do conto narrado. Ambos formulam imagens, com base em suas experiências individuais e nos fatos narrados e descritos pelo contador. A 
verossimilhança ${ }^{87}$ dos acontecimentos narrados parece estar presente, quando as pessoas da plateia 'enxergam' objetos, lugares, características de personagens e pequenos detalhes, sendo afetada pelos significados suscitados. O contador tem recursos para isso.

Segundo Busatto, o contador de histórias

lança ao ouvinte uma gama de imagens, com as quais esse sujeito-ouvinte irá construir uma paisagem interna, combinando o que ele já possui, enquanto repertório imagético, com o que ele recebeu durante a narração, e assim torna-se co-autor da história narrada, visualizando-a e construindo-a da forma que melhor Ihe convier (2006, p. 66).

Dar detalhes que enriquecem uma imagem é diferente de dar explicações, criticadas por Benjamin (1975). O contador experiente se orienta de diversas formas, para instigar a imaginação criadora no ouvinte, no lugar de ficar tentando 'convencer' o ouvinte com detalhes explicativos. Em uma piada, por exemplo, é mais fácil perceber, pois o bom da piada é entender sozinho, intuir seu significado construindo sua própria imagem. Nada mais desagradável e sem graça do que ouvir uma 'explicação de uma piada'.

Essa compreensão sem explicações é possível, pois como explica Eliana Stort, é "a partir do "ruído de fundo", ou seja, dos encontros de ideias, imagens e recordações que formam nossa vida interior, que se constrói o "Logos", no sentido do termo grego: discurso, palavra, pensamento, ação" (STORT, 1989, p. 41). Para a autora, imaginação e razão estão intrinsecamente relacionados e, é esta capacidade que nos distingue dos seres vivos. A autora deixa um alerta, de que a função criadora da imaginação é, por vezes, reprimida ou desvirtuada e, quando a vida é dirigida de fora, a pessoa aceita passivamente as respostas prontas, sem se dar conta disso, pois não realiza o movimento interno de reorganização dos sentidos e imagens. A criação das imagens depende do reconhecimento de uma ação, assim explicadas por Girardello:

Essa compreensão que atribui à imaginação um papel decisivo na administração das demandas éticas e estéticas, tanto individuais como sócio culturais pode ser associada ao conceito de imaginação de Paul Ricoeur, também inseparável da preocupação com a narrativa. Ricoeur frisa

\footnotetext{
${ }^{87}$ Esta aproximação com o real é o que atrai o ouvinte para dentro do conto, independente de sua correspondência com qualquer realidade concreta. É como se a realidade de dentro do conto existisse por si só, onde há espaços para fantasias e criações.
} 
que toda ação depende da imaginação, e que é no espaço da imaginação que experimentamos diferentes cursos de ação, e que "brincamos" - no sentido literal do termo, ressalta - com possibilidades práticas (1998, p. 39).

A autora comenta a ênfase no fazer narrativo como brincar imaginativo, de Paul Ricoeur, que coincide com o fundamento lúdico que acompanha minha prática de contadora e formadora, acompanhando, também, outros autores contadores. Como mostra Zurk em seus registros: "Os caminhos do imaginário podem nos conduzir à esfera multinterativa entre o lúdico, o criativo, a estética e as artes" (2008, p. 128). O espaço do jogo que garante a manifestação lúdica garante, também, o espaço para criação e pode ser dirigido a exercícios de criação imaginária. Brincar faz parte de ser gente responsável e séria, que sabe aceitar mudanças e encarar o novo! Concordando, novamente, com Girardello:

Tanto a criança que brinca quanto o escritor criativo distingui perfeitamente sua criação imaginativa da realidade. (...) O devaneio adulto, a fantasia, a viajar acordado, servem à mesma função que a brincadeira infantil, ou seja, à satisfação de desejos (1998, p. 31).

A autora me levou a perceber que a experiência primordial contida na criação imaginária, considerada tanto por Freud como por Benjamin, revela a importância de experiências que ampliam espaços para essa imaginação criadora, ao mesmo tempo, que fornece argumentos para a necessidade desse entendimento na infância. Quando encontramos adultos que não conseguem se soltar nas brincadeiras das oficinas, investigando mais de perto se descobre que também não brincaram em sua infância. Essas experiências, agora, no tempo presente, não encontram ressonâncias como em nós, que tivemos muitas oportunidades, consequentemente, as dificuldades são maiores.

Regina Machado (2004b) confirma a importância do brincar, quando diz que quem brinca tem maiores tendências de aceitar transformações, é mais flexível. Por isso é tão importante brincar, ouvir e repetir as histórias.

A imaginação permite que cada ouvinte idealize determinado objeto, cenário, ou detalhe da história, de acordo com suas experiências pessoais, portanto, diferentes umas das outras. Um exemplo prático pode ilustrar melhor o que acontece entre o contador e o ouvinte: após uma sessão de contos, ao dirigir-se a atenção para os ouvintes, são comuns os suspiros e comentários descrevendo objetos, cenários ou características de personagens da história que acabou de ouvir. 
Observando estes comentários, sobretudo em cursos ou eventos específicos de contadores de histórias, identifiquei, várias vezes, comparações com imagens construídas e relatos de detalhes que sequer existiram na narração do conto, como cores, tamanhos, cheiros e texturas.

Com essa observação, comecei a investigar: por várias vezes tive a oportunidade de confirmar a criação de imagens, com base em um mesmo objeto, formulando uma única pergunta, depois de contar a mesma história. Por mais de quinze anos, anotei resultados e, revisitando meus apontamentos, ainda hoje me surpreendo com tamanha variedade de formas geradas com base em um único estímulo, e, por outro lado, a presença garantida na diversidade de formas suscitadas.

A história escolhida é um poema de Cora Coralina, que trata da infância de Aninha (como era chamada a autora), quando se fazia um "bolo" em sua casa:

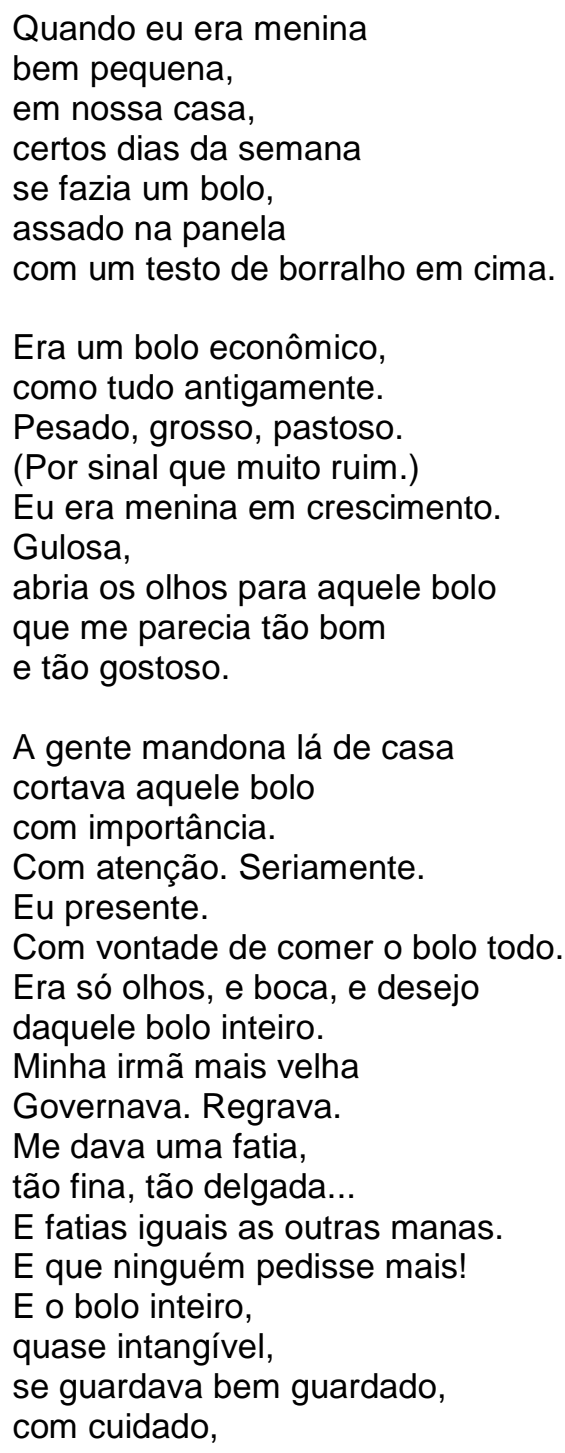

A gente mandona lá de casa cortava aquele bolo com importância.

Com atenção. Seriamente.

Eu presente.

Com vontade de comer o bolo todo.

Era só olhos, e boca, e desejo

daquele bolo inteiro.

Minha irmã mais velha

Governava. Regrava.

Me dava uma fatia, tão fina, tão delgada...

$E$ fatias iguais as outras manas.

$E$ que ninguém pedisse mais!

E o bolo inteiro, quase intangível, se guardava bem guardado, com cuidado, 
num armário, alto, fechado, impossível.

Era aquilo, uma corsa de respeito.

Não pra ser comido assim, sem mais nem menos (...) (CORALINA, 1997, p. 53/54) ${ }^{88}$.

Quando perguntado aos ouvintes sobre as imagens formuladas durante a narração, a primeira observação aponta para as respostas: o "bolo" e o "armário", nunca ocorrendo uma sessão em que esses dois objetos faltassem nas respostas.

Aprofundando as investigações e escolhendo como objeto de análise o 'bolo', foram anotadas imagens de bolos de todas as formas e cores possíveis, apesar da descrição detalhada da autora apresentar um bolo assado na panela, portanto, no mínimo um bolo redondo. Ao contrário do esperado, os exemplos eram sempre diversificados: "bolo de chantilly com morango", "bolo de três andares", "bolo de cenoura com cobertura de chocolate, cortado em quadrados", mostrando que a parte objetiva do detalhamento do bolo era menos importante do que a vontade final de comer o bolo. Isto, porque ficava visível para mim que as imagens construídas pelos ouvintes se relacionavam com bolos gostosos e desejados por eles, o que não ocorre no poema.

Recentemente, tive a oportunidade de confirmar essa experiência, quando contei essa história no aniversário de 82 anos de minha mãe, para um público de professores aposentados da UFG. Qual não foi minha surpresa ao escutar de meu pai: "a imagem de 'bolo' que veio à minha mente era de um bolo em formato de coração, glaçado... (risos)". E seguiu com a descrição, explicando que o glacê era uma cobertura feita pela mãe dele (minha avó), com clara de ovo e muito açúcar, bem branquinha... Detalhe que mostrava o distanciamento do trecho do poema que descrevia o bolo: "assado na panela, com um texto de borralho em cima". Se o borralho era preto, na imagem formulada por mim, como a memória de meu pai conseguia produzir uma imagem tão branquinha, e ainda sem perturbar o entendimento da história? E como conseguíamos comungar do momento, mesmo imaginando formas diferentes?

\footnotetext{
${ }^{88}$ Trecho do poema "Antiguidades", de Cora Coralina, do Livro: Poemas dos Becos de Goiás e Outras Histórias Mais. Encontrado também no endereço virtual:

http://goiabadademarmelo.wordpress.com/tag/poema-do-livro-poemas-dos-becos-de-goias-e-estoriasmais/
} 
Enquanto isso, outra amiga retrucou: "Ah não! O meu era assado em uma forma retangular, grande, cortado em quadradinhos", sugerindo se aproximar mais da descrição do poema, mas fazendo o mesmo movimento do exemplo anterior. $E$ os olhos deles brilhavam enquanto descreviam. Outra amiga, de origem goiana, descreveu o bolo análogo ao da história, acrescentando detalhes do fogão de lenha onde era assado. Isso mostra que as imagens dependem de nossa vivência individual e se ligam a ela, conforme Bachelard (2000).

E, como foi servido o bolo da festa, logo em seguida, as conversas sobre bolos e contadores de histórias se arrastaram pela tarde a fora, mostrando-me, finalmente, que mesmo não sendo possível a formação de imagens semelhantes, no entendimento das histórias, sua compreensão, por parte de quem ouve, não fica comprometida. A comunhão do conto independe do tipo ou grau de entendimento de cada um.

Provocados pelas imagens suscitadas pelo conto, naquele momento, 0 assunto rendeu pelo resto da tarde. Memórias e afetos vividos e imaginados pelos presentes se misturando a novas histórias, compondo novas e velhas imagens, revelando o dinamismo e o poder do ser humano, em interação com o outro. Uma vivência de alteridade.

Porém, não é papel do contador de histórias identificar a imagem ${ }^{89}$ que o ouvinte formula de qualquer parte da narrativa, ou querer que todos formulem imagens iguais, como se as pessoas fossem iguais. É no espaço íntimo do ser humano, descrito por Bachelard (2000), que as histórias permitem que se vivenciem as emoções mais profundas, emoções, por vezes, indecifráveis até para quem as experimenta, associadas às imagens que são formuladas. Portanto, tentar identificar imagens e emoções elaboradas pelas crianças ou qualquer ouvinte seria como uma invasão na intimidade do ouvinte, ao contrário do princípio de alteridade, que considero fundamental na construção do contador.

No universo dos contadores de histórias é como se a imagem estivesse contida na imaginação, que, por sua vez, está contida no imaginário, que é maior, pertencente a um repertório individual, e, ao mesmo tempo, ao repertório de uma coletividade (um grupo cultural). Enquanto a imagem se apresenta em sua forma

\footnotetext{
${ }^{89} \mathrm{~A}$ responsabilidade da investigação desse tipo de questão é extremamente delicada. A oportunidade que tive foi construída ao longo de minha prática de anotações com ética, preservando a identidade dos envolvidos, com a única intenção de entender o elo entre contador e ouvinte.
} 
concreta, possuindo contornos descritivamente objetivos, a imaginação é a capacidade de colocar a imagem em ação, ou seja, criar, formular ou construir uma representação, estimulada pela narração do conto. O imaginário é uma espécie de depositário, repertório, ou banco de referências para o entendimento, formação e/ou reformulação de velhas e novas imagens. Em certos aspectos, o imaginário é individual e único, pois depende da experiência de cada pessoa, mas, também é, ao mesmo tempo, coletivo, por ser função e produto, ocupando uma grande importância no domínio e compreensão do contador de histórias.

Ao lado da memória, a imaginação, igualmente, pertence aos fundamentos da presença do contador de histórias, na interação com seu ouvinte, na significação do conto. Entretanto, outros dois componentes pertencem ao conjunto da presença do contador: a emoção e a espontaneidade.

\subsection{As emoções suscitadas pelas histórias}

O encantamento é um estado de conhecimento. Regina Machado

Quem nunca se emocionou ouvindo uma história? Lida, contada, desenhada ou filmada, pode-se afirmar que as histórias emocionam os que entram em contato com ela, por meio de qualquer linguagem, fazendo emergir sentimentos, emoções e sensações várias. Refiro-me àquele conto que não escolhe idade, tipo de pessoa ou classe social, agrada se não a todos, à maioria, seja por sua astúcia ou pela estrutura que escolhe e envolve as palavras. Os contos tradicionais, sobretudo os arquetípicos, que atravessaram milênios, acompanhando gerações em suas transformações culturais, são exemplos de contos que emocionam. Contudo, na atualidade, além do repertório tradicional, a produção literária, sobretudo na literatura infantil e juvenil brasileira, que constrói parte do repertório dos contadores de histórias atuais, tem crescido com intensidade, alargando o repertório dos mesmos, que emocionam e encantam os ouvintes que se dispõem a ouvir.

A emoção do conto é sentida pelo ouvinte, quando este se permite. Segundo Celso Sisto "o que vale mais é sentir a liberdade de ser coautor da história narrada" 
(2012a, p. 23), e criar, na imaginação, os cenários, dividindo a emoção do conto com os personagens, durante a narração, cada um a seu modo. A disponibilidade para criar uma cumplicidade entre o ouvinte e a história é dada pelos espaços criados pelo contador, para o ouvinte se envolver e recriar a história, sentindo suas próprias emoções e criando suas próprias imagens. Estes espaços "dentro de uma história podem ser construídos pelas pausas, silêncios, ações, gestos e expressões de forma harmônica" (idem, 2012a, p. 25). Isto quer dizer que: "O que o ouvinte espera do narrador, neste momento, é que haja entre eles uma correspondência direta de emoções e sensações" (idem, 2004, p. 87), proporcionada pela interação entre o contador e seu ouvinte. Considero que as emoções estão presentes, junto com as imagens sentidas ou formuladas.

Ao buscar o conceito de emoção, analiso seu uso junto ao contador e ao ouvinte de histórias, portanto, no momento da narração oral, envolvendo quem estiver presente, ligado na narração; no momento solitário da preparação do conto, em que o contador investiga, aprofunda, conhece e seleciona as emoções que envolvem o conto. Deste modo, considero que emoção é um estado psicofísico do ser humano, uma vez que envolve sensações físicas, químicas e psicológicas do organismo, ao mesmo tempo que abrange sensações internas e subjetivas, que se expressam por meio de sentimentos e sensações; é uma resposta ou uma reação a um estímulo externo ou interno, que movimenta o sentimento de cada um, causando reações semelhantes e diferentes.

O contador de histórias é como se fosse um reanimador do conto. Como dizem os integrantes do Morandubetá ${ }^{90}$, (talvez inspirados no texto de Walter Benjamin - O Narrador) um texto ganha vida quando começa a circular, ou seja, quando é lido ou contado para alguém ouvir. O contador de histórias é alguém que dá vida ao texto oral ou escrito, que ressuscita sua capacidade de emocionar, por meio da narração.

Um ponto importante a ser considerado é a responsabilidade da emoção despertada no ouvinte, pelo contador da história, que deve ter conhecimento do poder que tem de provocá-la. Um texto ganha vida quando começa a circular nos olhos de quem lê, na boca de quem conta, e nos ouvidos de quem ouve. Essa vida é marcada pelas emoções e pelo imaginário que o texto é capaz de acender. Nas

\footnotetext{
${ }^{90}$ Grupo Morandubetá foi meu primeiro contato com a sistematização do contar histórias. Essa ideia tem sido repetida, por vezes, em palestra e oficinas, sobretudo, com Eliana Yunes e Celso Sisto.
} 
histórias, tudo pode acontecer porque as ações duram somente o tempo em que elas estão vivas, ou seja, enquanto estão sendo lidas ou contadas. Quando a história acaba, as emoções foram experimentadas e a realidade volta a ocupar a rotina.

A manifestação da emoção é uma das primeiras responsabilidades do contador de histórias, que ao suscitá-la em seus ouvintes, cria um clima de envolvimento com a narração, fazendo parte do processo da interação entre ouvinte e contador.

Assim como desperta as imagens, o contador quer também acender em seus ouvintes as emoções provocadas pelas histórias, que são despertadas, ou não, de acordo com cada contador em sua forma de contar, com os recursos e conteúdos que o texto oferece, e na forma pela qual o ouvinte recebe, com base em suas experiências pessoais. Isso porque, cada um possui uma maneira única de sentir e se relacionar com o mundo a sua volta e com seu interior.

Segundo o médico e contador de histórias Conrado Mariano, as narrativas carregam traços das culturas, exigindo do ouvinte que se coloque no lugar do contador para entendê-las. Porém, as emoções que o conto carrega ele considera como categoria universal. "Não há ser humano, de qualquer parte do mundo, que viva sob lá qual for o regime político ou religioso, sob qualquer cultura, que não tenha emoções" (MARIANO, 2011, p. 209). Cléo Busatto corrobora com a ideia:

Do primeiro movimento, ao redor da fogueira, onde soou pela primeira vez a voz de um contador de histórias, até no ciberespaço, onde pode soar a voz de um contador do tempo de agora, se passaram séculos. Porém, o que sustenta essas ações é a história que, enquanto sujeito, engendra o encantamento necessário para nos emocionar (2011, p. 102).

O narrador oral transbordado de encantamento pelo texto contagia seu ouvinte, suscitando-Ihe as emoções do conto. A emoção contida nas histórias e desfiada pelos contadores, dando vazão a outras emoções particulares, não só alimenta essa arte, como também é responsável por sua manutenção. Essa emoção é tanto do narrador oral como da plateia, ocorrida no momento do contar com, que propicia a comunhão do conto, ainda que sentidas e expressas de formas diferentes, em cada pessoa, assim como acontece com as imagens.

"O que o contador de histórias quer é provocar emoções nos seus ouvintes, por isso cria formas específicas para melhor atingi-los" (SISTO, 2012a, p. 48). 
Comigo acontece de a emoção ser despertada, no momento da escolha da história. É pelo afeto que a história me prende e me provoca vontade de compartilhar, pelos vários sentimentos que são despertados em mim, escolho, ou não, incorporar aquele conto em meu repertório. Não há como traçar caminhos ou indicações para essas escolhas, porque a emoção pertence a cada um, de forma individual.

$\mathrm{Na}$ experiência de Celso Sisto, me identifiquei com seu relato: "Eu tenho uma razão para contar! E ela fala na minha voz, ganha forma no meu corpo! Indica-me o que vem da emoção e o que deixa de vir por desidentificação, mastigação, distanciamento, despreparação, obrigação!" (2012a, p. 84). Quando o contador não alcança envolvimento afetivo com o texto, dificilmente conseguirá externalizar suas emoções, comprometendo a credibilidade e/ou compreensão da história. "Também há a distância e o tempo empurrando os olhos para as imagens prontas e as palavras frouxas que não acendem a imaginação" (SISTO, 2012a, p. 23) e, consequentemente, não emocionam. Não confiando nas próprias palavras, o contador não pode querer que seu público acredite, aceite e/ou entenda a história. É como se as palavras não tivessem sentido e se perdessem no meio de tantas outras. São palavras sem força, sem cor, cheiro ou sabor, ou seja, sem emoção.

A experiência leva o contador a compreender a subjetividade do controle da emoção, para não entregá-la pronta, ou com excesso, aos ouvintes, inibindo-os de vivenciar seus próprios sentimentos. Uma indicação que tento compartilhar é que o contador deve vivenciar as emoções suscitadas pelo texto, sem exagerá-las, o suficiente, apenas, para indicar sua presença, a ser complementada pelo ouvinte. $O$ elo se forma novamente, onde ouvinte e contador recriam as emoções que orientam cada fato narrado.

O contador está a serviço da história que narra! Torná-la atraente, expressiva, instigante, estimulante e prazerosa é também não dar para o ouvinte todos os elementos mastigados e prontos. (...) A forma seja qual for (...) deve funcionar muito mais como um esboço a ser preenchido pelo ouvinte do que um espetáculo pronto e acabado! (SISTO, 2012a, p. 102).

O contador pode se emocionar ao contar a história, mas não vivencia com toda a intensidade essa emoção, no momento da narração, e sim, estimula o ouvinte a essa experiência pessoal, por meio de técnicas, conquistadas pela prática. Essa prática busca meios de atrair a expectativa do ouvinte por meio da sonoridade empregada nas palavras. Na explicação de Sisto: 
A palavra, com seu poder de evocar imagens, vai instaurando uma ordem mágico-poético, que resulta do gesto sonoro e do gesto corporal, embalados por uma emissão emocional, capaz de levar o ouvinte a uma suspensão temporal (SISTO, 2012a, p. 32).

Essa suspenção do tempo é a passagem para o mundo do imaginário, o tempo afetivo passa a prevalecer, na interação do contador com seu ouvinte. Acontece somente na permanência da narração, isto é, durante o momento em que as palavras repercutem, no ambiente externo e interno dos ouvintes. Celso Sisto coloca a necessidade de se estar inteiro para lidar com a emoção do conto, e que a prática é o melhor caminho para aprender a lidar com as emoções, que são individuais:

\footnotetext{
Se o contador estiver, ele mesmo, inteiro no que estiver fazendo e exercitarse o suficiente para conseguir destravar sua emoção no momento mais adequado, ele pode até considerar-se um demiurgo (uma espécie de vidente). A mágica aqui é apenas a prática (SISTO, 2012a, p. 46).
}

Complemento a fala de Sisto com a observação de Santos:

Com relação à linguagem, por exemplo, é interessante notar que o contador
de histórias conduz o ouvinte à descoberta de novas palavras, transporta a
plateia a viagens imaginárias, permitindo que as emoções vividas na mente
e em certo grau no corpo - o que leva o espectador a ampliar o seu
universo simbólico, bem como seu repertório de respostas às demandas do
meio (SANTOS, 2004, p. 168/169).

O que conduz o ouvinte, nesta viagem, e permite a interação contador/plateia é sempre repetido por Celso Sisto, em suas oficinas, como já pude testemunhar diversas vezes, é a credibilidade na história narrada. Ou seja, ele deve passar verossimilhança nos fatos, fazendo com que as pessoas acreditem no que está sendo narrado. Tentar fazer com que o público enxergue essas imagens, ou melhor, formule suas próprias imagens e sinta as emoções, de acordo com o que está sendo contado, conforme sua experiência particular, é a tarefa do contador. Hoje, entendo que a indicação do autor era a necessidade de o contador acreditar no fato narrado, e usar as imagens internas e a emoção, para isto, sentindo-se parte da história.

Nesse sentido, Regina Machado conta ter aprendido com sua avó que um narrador oral tem de ser "Eterna e inquebrantavelmente fiel à história" (2004b, p. 38) a ser contada. Para mim, esta fidelidade está, também, nas emoções que construo 
durante o estudo e internalização do conto, evocando-as no momento da narração, para que penetre nos significados das palavras, atribuindo-Ihes sentido. Como diz Celso Sisto:

\begin{abstract}
Com os olhos voltados para o imaginário o ouvinte ultrapassa a compreensão pura e simples de uma história. Ele é atingido - ao menos que se desligue - por uma ininterrupta carga emocional. Essa carga de emoções são estimuladas pelos recursos que o contador escolheu para empregar em sua performance, com a intenção de fazer com o outro o que uma história já fez com você (2004, p. 88).
\end{abstract}

Ainda que sejam emoções distintas, o que se quer é o envolvimento do ouvinte, compartilhando o que a história oferece. Além dos recursos pessoais escolhidos pelo contador, o clima anterior à história aguarda revelação de segredos, em que os ouvintes serão depositários do mistério e do saber poético sensível que as histórias carregam, em uma estética que se cumpre, enquanto o narrador oral utiliza formas e estratégias ao narrar (SISTO, 2004). Isto colabora na abertura de espaços para aproximação entre contador e ouvinte.

Outro alvo de abordagem sobre a emoção nas histórias são os estudos realizados sobre os contos de fadas e contos tradicionais, por diversos autores, em razão de seu envolvimento com a fantasia, ponto já abordado, anteriormente, junto ao imaginário. De acordo com Zurk (2008), a carga de emoção que o contador consegue suscitar no ouvinte influi diretamente na experiência da criação de imagens e na significação do conto, isto é, em sua audiência.

Contos de fadas ou contos maravilhosos são aqueles que têm a presença de fada ou bruxa, ou de um elemento mágico como, por exemplo, a "lâmpada" de Aladim, a "bota" do gato, o "tapete" voador. Pertencem ao gênero dos contos tradicionais, cuja característica é sua fórmula própria de lidar com problemas arquetípicos, que são inerentes à espécie humana. Bruno Bethelheim (1984), analisando os contos de fadas, explica que a fórmula de abertura do conto conduz 0 ouvinte imediatamente ao mundo imaginário, mundo da fantasia, pela distância do real, provocada pelas expressões de início. Regina Machado (2004a.) e Gislayne Matos (2006) apresentam listas dessas expressões utilizadas pelos contadores tradicionais, que abrem e encerram os contos tradicionais, que ainda são encontradas com bastante variação. São como condutores que levam e trazem o ouvinte, do mundo real para o mundo da fantasia, e de volta do mundo fantástico 
para a realidade cotidiana. Neste mundo da fantasia, representado por um espaço diferente do mundo real, as emoções são acolhidas, sejam elas quais forem consentindo sua vivência, que nem sempre é possível na vida real. O mundo da fantasia é, então, um espaço para vivência de emoções internas, fundamentais para o entendimento e desenvolvimento dos sentimentos humanos. Um rico exemplo é a contadora Laura Simms, cuja experiência envolve contar histórias para crianças após grandes tragédias:

O medo não deve ser evitado nem reprimido, nem conquistado. Pois é das profundezas do medo que surgem o destemor, a consciência e a sabedoria. O reconhecimento a e experiência do medo são a porta que se abre levando-nos a uma presença e a uma percepção mais elevada, através das quais aprendemos a viver o mundo tal como ele é (SIMMS, 2004, p. 58).

O que ela está dizendo é da oportunidade do medo e sair-se vitorioso, pelo menos nas histórias, espaço para vivência de emoções. O psicanalista Bruno Bethelheim (1984) estudou, com profundidade, os significados subjetivos relacionados às emoções humanas, que, segundo o autor, se encontram presentes nos contos de fadas ocidentais, em que as principais referências são os contos registrados por: Perrault, Irmãos Grimm e Hans Christian Andersen ${ }^{91}$. Para o psicanalista, os contos de fadas falam de toda a saga de problemas da humanidade, mas sempre encontram um final feliz, sendo esta uma das características de sua composição e indicação terapêutica ${ }^{92}$.

Pondero que a identificação dessas emoções, nos ouvintes, seria uma invasão ao mundo subjetivo do outro. Esse comportamento tem lugar nos consultórios, onde há um acordo e uma permissão para discussão das emoções e quebra de condicionamentos. Os contos ajudam as pessoas, por exemplo, a identificar seus estados emocionais e a superá-los de várias formas (BAIRD, 2004). Sua utilização em psicoterapias tem sido de grande valia, pois "Um conto, mesmo fictício, ilumina a verdade", segundo pensamento do Mestre Rumi, séc. XIII.

Alguns estudos específicos desta área são apontados pelas contribuições que podem trazer no autoconhecimento do contador de histórias em construção, ainda que os focos do sejam diferentes. Alessandra Giordano (2007); Maria Tatar (2004);

\footnotetext{
${ }^{91}$ Esse tema será retomado no quarto capítulo, onde os autores são apresentados com referências aos respectivos repertórios.

${ }^{92}$ Embora as críticas ao autor Bruno Bethelheim possam ter fundamento, o que está colocado aqui é a consideração de que os contos de fadas são espaços para vivências de emoções arquetípicas.
} 
Nancy Mellon (2006); Margot Sunderland (2005) são terapeutas que utilizam a contação de histórias como ferramenta para seu trabalho profissional. O contador de histórias em sua profissão de contar, pode aprender com o contador terapeuta, mas não exercem a mesma função e nem tem o mesmo tipo de responsabilidade.

Os contos são universais e se particularizam em cada cultura, por isso, podem favorecer a consciência da nossa identidade (MACHADO, 2004a.). E por isso, também, os contos tradicionais são conhecidos em vários lugares com algumas modificações, que revelam traços culturais e/ou épocas distintas.

Nos contos de fadas a imaginação acompanha a presença dos elementos mágicos, nas fábulas, as falas e ações de bichos se assemelham às atividades humanas. Essas características podem amparar o contador no estudo da emoção do conto, pois os contos tradicionais colocam o ouvinte/leitor em contato com os valores humanos fundamentais. Regina Machado oferece pistas para esse entendimento:

\footnotetext{
Cada narrativa expressa um caminho, um percurso de desenvolvimento, envolvendo necessidades, questões e conquistas: os desafios, provas e obstáculos permeiam as ações de heróis e heroínas que enfrentam situações em que os valores humanos como coragem, liberdade, beleza, determinação e justiça subjugam o medo, a inveja, a covardia, a traição. Por meio de variadas situações humanas (2004a., p. 32).
}

Por meio da emoção vivida nas histórias, fortalecemos nossas experiências individuais, ao mesmo tempo em que passamos a pertencer à uma experiência universal, que nos une enquanto seres humanos, dotados de capacidades de sentir.

Para provocar vivência de emoções durante uma narração, depende do que o texto oferece e o contador consegue suscitar. Geralmente, as emoções são expressas na face e no corpo, tal como são sentidas pelas crianças, que quando adultos, em nossa cultura, demonstram dificuldades de expressá-las, seja pelo cerceamento imposto nas regras sociais, seja por medo da exposição, ou até por falta de oportunidades, durante seu desenvolvimento. A vida agitada do mundo moderno, cheio de regras e condicionamentos para comportamentos específicos, cria barreiras que impedem ou dificultam o uso da linguagem corporal. Entretanto, é a expressão facial e de todo o corpo que possibilita a externalização da emoção do contador. Como explica Sisto: 
geral, busca um bom contador de histórias, já que a emoção provocada no ouvinte-espectador também depende muito do seu amplo espectro de expressão corporal (SISTO, 2012a, p. 104).

Externalizar a emoção provocada pela história éuma construção do contador, que está diretamente relacionada ao conhecimento de seu corpo e de sua capacidade expressiva. A diretora de teatro, teórica e criadora dos jogos teatrais bastante difundidos no Brasil, Viola Spolin, orienta que:

não devemos usar a emoção pessoal ou subjetiva (que usamos na vida diária) para o palco. É um assunto pessoal (como sentir ou acreditar) e não algo para ser mostrado no palco. No máximo, a emoção "verdadeira", colocada no palco, pode ser classificada como psicodrama (SPOLIN, 2005, p. 14).

Assim, entende-se que a emoção externalizada é construída internamente pelo contador de histórias, que ao estudar a história vai distinguindo as emoções envolvidas e se apropriando delas. De acordo com Margarida Baird:"Os contos são muito mais profundos do que aparentam e que, quanto mais se conta uma história, mais se aprende com ela" (2004, p. 73). Então, não é só durante o estudo que se aprende sobre o conto, as emoções podem ser diferentes a cada contato com a história, porque depende do que nos toca naquele momento, contador e ouvinte.

Viola Spolin (2005) entende que, para a conquista da emoção no teatro, a ação deve ser externa e visível. Por exemplo, pentear os cabelos, usar um objeto ou ler, para que, por meio desse ato, seja revelada a ação interna que é a emoção (alegria, raiva, fome, tristeza, ou qualquer outra). Dessa forma, a emoção se torna concreta para o público. Isso é importante, porque de acordo com Shedlock: "O narrador é responsável por todo o drama e também pela atmosfera que o cerca" (2004, p. 27).

A emoção de cada personagem não se confunde com a emoção do contador, porque é entremeada pelo narrador, na dinâmica de cada conto. Isso dá liberdade ao público de interpretar a história à sua maneira. O espaço criado pelo contador, para que o ouvinte possa manifestar, ou não, os sentimentos que a história the despertou é subjetivo e depende de cada um. Por exemplo, quando um personagem fica muito triste com o que the ocorreu, por mais que o choro represente essa tristeza, pode ficar exagerado, pois alguns ouvintes podem ficar confusos entre personagem e contador, causando ambiguidade e, consequentemente, dificuldades 
na compreensão da história. Para o contador de histórias o texto, é onde está o foco, a atenção principal de todos os envolvidos, contadores e ouvintes, à mercê das emoções que um conto oferece.

Partilhar com a criança a emoção e a lucidez que as histórias nos trazem é uma forma elevada de ação educacional (FOX e GIRARDELLO, 2004), que, no meu entender, alcança a alma do ouvinte.

É por meio dessas vivências particulares que ouvintes e contadores, cada um com sua experiência, criam e recriam as imagens da narrativa, permitindo a fruição de suas emoções. O contador conta 'com' o público que, estabelecendo uma cumplicidade, constrói os significados do que está sendo narrado. "A imaginação modifica certos aspectos da narrativa e é capaz de ampliá-los enquanto os assimila, portanto talvez possamos alçar que o conto ajuda a memória a lembrar e a imaginação a imaginar..." (BEDRAN, 2011, p. 62). Talvez possamos ampliar: o conto ajuda a emocionar! O que nos leva a pensar que memória, imaginação e emoção são fatores indispensáveis a qualquer contador de histórias, conquistadas pela espontaneidade que, enfim, complementa a presença do narrador, a ser investigada, a seguir.

\subsection{Espontaneidade na ação de contar}

Contar histórias é doar o que se tem de melhor no coração. Mestre Rumi

Esse pensamento ilustra e explica o encantamento provocado pelo contador de histórias, que consegue encantar porque tira aquilo que vem de seu coração e envia ao coração do outro. Vejo isso na simplicidade dos contadores tradicionais, e acho que é isto que mais aprecio neles, por serem naturalmente espontâneos, tendo aprendido sem necessidade de uma sistematização ou estudo. São pessoas que possuem maior facilidade e flexibilidade com as palavras, sem a necessidade de ensaios ou preparação sistematizada, sendo capazes de criar e recriar, no próprio desenvolvimento do contar. Arrisco-me a dizer que, em sua grande maioria, são pessoas que, de alguma forma, conviveram ou convivem com a cultura oral, ou 
tiveram oportunidades de ouvir muitas histórias, em seus lares e comunidades, ou seja, aprenderam a fazer, fazendo, observando e recriando.

Girardello (2004) apresenta Laura Simms, em seu livro, como referência para os interessados no tema. Inesquecível pela integridade de sua presença, no momento da narração, pela poesia espontânea de sua fala, e pela originalidade das associações de ideias. Possui uma rica experiência de contar histórias em lugares onde a condição de vida é quase sub-humana, por consequência de acidentes como: terremotos, tsunamis e outros. Tive a feliz oportunidade de conhecer sua atuação, no encontro 'Boca do Céu', em 2012, promovido por Regina Machado, aderindo às observações de Gilka Girardello. Ao pensar nesta característica do contador, procuro lembrar sua narração, anotando o que me chama atenção. O que garante a espontaneidade da contadora? É possível aprender a ser espontâneo?

O contador de histórias tradicional tem facilidade de prender a atenção das pessoas que estão à sua volta, sendo a espontaneidade uma das características que saltam aos olhos de um observador, que procura pelo estado de presença do narrador. Acredito que a característica de ser espontâneo, enquanto conta uma história, pode ser uma conquista do contador na preparação de uma história.

A convivência e a repetição são as bases do contador de histórias que precisa conquistar sua espontaneidade, perdida em meio às regras da vida urbana agitada. Ou seja, novamente é preciso praticar.

Muitas pesquisas sobre o Nordeste analisam repentistas em seus processos de aprendizagem, criação e desenvolvimento de técnicas, cujos trabalhos se apresentam de forma improvisada e espontânea. Faz parte da cultura regional. Exemplificar alguns, quando são tão numerosos, pode ser injusto. Deixo a tarefa de conhecer essa riqueza por conta da curiosidade de cada contador, respeitando as estéticas individuais, para não desviar do foco proposto, ao se perder pelos enredos atraentes e maravilhosos do cordel. Ao mesmo tempo, contrariando minha própria ideia de não dar exemplos, cito Patativa do Assaré como um dos poetas populares mais homenageados em eventos de educação e contadores de histórias, mas também para deixar apontada a contribuição, desses artistas, para a arte dos contadores. Para que o contador em construção possa ganhar a naturalidade nos improvisos e nas narrações ensaiadas é preciso conhecimento, um grande vocabulário e capacidade de organizar rapidamente um pensamento. 
Os contadores que trabalham com histórias literárias são unânimes em considerar as dificuldades de leitura, em seus alunos, no sentido de colocar fluência verbal e entonação na palavra escrita, aproximando-a da oralidade e se fazendo compreensível. Contar histórias de livro, de forma espontânea, fazendo o ouvinte vibrar, imaginar e se emocionar, exige domínio da leitura. Exige conhecimento do contexto e treino da leitura. A discussão com base na sociolinguística, apresentada no próximo capítulo, explica a distância e os problemas entre as linguagens oral e escrita, que dificultam a apropriação da leitura fluente, por não pertencer à linguagem que o aluno conhece e utiliza. Eliana Yunes oferece caminhos para superação:

\begin{abstract}
A correção desse problema vem com a naturalidade à medida em que a familiaridade com a leitura aproxima as estruturas do "bem dizer" da fluência oral do falante. Isso significa em outras palavras, que quanto mais ele "ouvir" textos bem escritos, melhor será seu desempenho verbal, falando ou escrevendo e, certamente, terá resistências cada vez menores à leitura (YUNES, 2012, p. 63).
\end{abstract}

Sem dúvida, contar é diferente de ler, e a experiência com a linguagem interfere nas facilidades ou dificuldades, que podem ser superadas. Para a atriz Estrella Ortiz (2004), contar é diferente de interpretar e, no fundo, se misturam:

\footnotetext{
Uma discussão sobre os limites entre interpretar e narrar seria totalmente estéril: num nível profundo o ator ${ }^{93}$ sempre conta o que quer que seja, e 0 narrador sempre interpreta, pois revive algo que não acontece naquele momento (ORTIZ, 2004, p. 104).
}

No momento, o interesse é perceber a importância de uma preparação prévia, tanto para contar, como para interpretar que, em muitos pontos, podem ser coincidentes.

Marie Shedlock (2004) considera uma falácia achar que não é preciso preparo para se contar uma história ou declamar uma poesia, que, para ela, são coisas diferentes. A diferença entre um rígido recitador (que atende a modelos préorganizados) e o contador de histórias é que com o esse último nunca se sabe o que se vai ouvir, enquanto o recitador já está decidido, ensaiado e marcado, anteriormente. "Somente quando se conseguiu superar as dificuldades mecânicas

\footnotetext{
${ }^{93}$ Assinalo a existência de uma considerável discussão sobre as semelhanças e diferenças entre o ator e o contador de histórias e, ao mesmo tempo, a decisão de não entrar nesse mérito, em razão do meu foco se direcionar ao contador em construção, sendo este ator ou não.
} 
que se consegue "deixar levar" pelo interesse dramático da história" (SHELDLOK, 2004, p. 21). Concordo com a autora, ponderando que a conquista da espontaneidade pode dar vida a um poema, fazendo o ouvinte viajar, como em um conto tradicional, a exemplo do poema Antiguidades, de Cora Coralina, analisada anteriormente.

Talvez a espontaneidade seja um dos recursos mais perceptíveis no primeiro contato do contador com o público, principalmente por meio do olhar. Ao ser espontâneo, o narrador oral oculta a timidez e se dispõe a uma interação com a plateia. Essa facilidade advém da segurança do texto. Porém, é pertinente que ainda permaneça aquele frio na barriga, o da pré-estreia, pois significa a responsabilidade do palco ${ }^{94}$, ou do fato de estar em evidência. Logo, após os primeiros momentos de palco, o frio na barriga tende a desaparecer, dando lugar aos resultados do que foi conquistado com a preparação, a imersão profunda na história. Esse comportamento de controle da emoção e da ansiedade é conquistado com a prática, com o autoconhecimento e domínio dos recursos corporais e do conteúdo do texto. De tanto repetir, a gente começa a sentir e viver aquilo como experiência incorporada.

A espontaneidade e a naturalidade são adquiridas pelo domínio que se tem da história, por meio da paixão pelo que se faz e do esforço para consegui-lo. Ao assumir com Celso Sisto, que "o contador de histórias é testemunha ocular daquilo que está narrando", o contador se impõe a necessidade de acreditar nas próprias palavras, para que o ouvinte possa confiar, deixando o texto mais seguro e natural. Se ele "viu" como "testemunha ocular" é como se tivesse acontecido com ele, por isso, ele acredita e formula as imagens, sendo capaz de revelar detalhes ainda que ausentes no texto de origem.

$E$ isso acontece quando o contador é espontâneo e conduz, naturalmente, 0 ouvinte para fora do tempo real, para dentro do mundo da história. Na explicação de Laura Simms:

\footnotetext{
Apesar de o enredo da narrativa levar consigo a mente lógica, presa no transe de querer saber o que virá depois, as imagens e o sentido da história estão mais no fundo, o que faz o ouvinte mergulhar cada vez mais profundamente - trazendo no retorno à superfície toda uma riqueza de conhecimento intuitivo, memória, compaixão e sabedoria (2004, p. 62).
}

\footnotetext{
${ }^{94}$ Como me ensinou Luiz Graciliano Sales (regente do primeiro coral cênico que houve em Goiânia, com quem aprendi muito do ofício dos artistas).
} 
Esse fundo é o espaço imaginário onde o contador se liberta para conseguir ser espontâneo. Espontaneidade que se conquista com conhecimento, treino e experiência, mas que se traduz em simplicidade.

Shedlock traduz em uma palavra: simplicidade. Para ela "A simplicidade que precisamos é aquela que vem da naturalidade e produz a sensação de que podemos nos deixar levar, porque planejamos nossos efeitos" (2004, p. 23). Simplicidade não é descuido. Esse planejamento, na visão da autora, pode, por exemplo, atentar para os aspectos essenciais da história, que são a força de expressão e o instinto dramático, conquistados pela simplicidade.

Ensaios e treinos são necessários: "Isso não significa que o ensaio perca a naturalidade e a espontaneidade! O "truque" é exatamente estar treinado e seguro o bastante para que os gestos, e tudo o mais, brotem na hora em que precisarmos deles" (SISTO, 2012a, p. 103), ensina a experiência do autor.

Quanto mais a história for repetida, maior a probabilidade de ficar internalizada, fazendo parte da memória, do imaginário e das emoções do contador, como fato vivido, conquistando com maior naturalidade e espontaneidade em sua narração. Sinto a estrutura da história incorporada em mim, de forma a permitir as alterações que o contexto demandar, sendo diferente em cada contação. A espontaneidade se manifesta no improviso e exige experiência, que neste caso, é conquistada pela credibilidade do contador em relação ao texto, seja este de origem oral ou escrita.

Às vezes, pensamos (sobretudo em sala de aula) que não podemos ficar repetindo as histórias. Ao contrário, quanto mais se conhece o texto, maior 0 domínio, maior a possibilidade de liberdade e credibilidade, facilitando e enriquecendo a interpretação e os sentimentos, tanto do contador, quanto do ouvinte. Pelo lado do ouvinte, é gostoso ir reconhecendo as palavras e emoções de um conto, reencontrar personagens, aguardar, ansiosamente, por um trecho, esquecer, momentaneamente, o que vem depois, descobrir novos detalhes que não tinha percebido antes. $E$, às vezes, até tudo isso junto.

Acredito que a espontaneidade possa vir, também, do encantamento, como diz Celso Sisto: "Quando a história contada vem em função de instaurar um espaço lúdico, ela pode gerar um outro tipo de expectativa: não mais a cobrança, mas o encantamento" (SISTO, 2012a, p. 25). E, é esse encantamento que reivindico para o 
mundo, para o ser humano e, sobretudo, no cotidiano das escolas. "O contador de histórias tornou-se obrigatório na promoção da leitura e no resgate do lúdico e da fantasia" (SISTO, 2012a, p. 73). Eu ouso dizer que se tornou obrigatório, sobretudo, na escola, mas sem didatismos, preservando sua característica de encantamento.

Geoff Fox (2004) também aponta as necessidades de atenção ao ambiente físico da história, tais como: iluminação, ventilação, acústica, acomodação para os ouvintes e cenário, para contribuir na formação de um clima, uma ambientação. "O narrador é responsável por todo o drama e também pela atmosfera que o cerca" (SHELDLOK, 2004, p. 27). Cuidando do ambiente, preparando um clima aconchegante para que os ouvintes se sintam queridos e cuidados, auxilia na tranquilidade do contador e, consequentemente, na espontaneidade. Vários contadores concordam com essa preparação anterior. Alice Bandini prepara suas sessões de histórias:

Meu estilo pessoal sente necessidade de criar uma ambientação, um espaço que, ao chegar, o público se sinta acolhido e se remeta a outras sensações. O objetivo não é tirá-lo da realidade, mas acarinhá-lo. Posso dizer que isso não passou despercebido, principalmente em um espaço público (2012, p. 85).

Em sua experiência de contadora de histórias, ela relacionava a ambientação com o tema escolhido para cada mês, em seu trabalho na biblioteca. Acredito que preparativos anteriores influenciam no envolvimento e na presença do contador, que estando seguro de seu texto, consegue usufruir de sua espontaneidade e naturalidade durante a contação.

As produções acadêmicas, sobretudo na área do teatro, somadas a uma larga experiência com crianças, me levam a reconhecer e concordar que a espontaneidade é um componente inerente aos personagens da cultura popular, às crianças de um modo geral e aos bons atores, que estudam para isso. Observando a espontaneidade presente no comportamento da maioria das crianças, descobrimos que é possível aprender com elas. Uma criança tem o poder de chamar a atenção de todos que estão em um ambiente, seja em uma birra, daquelas de rolar no chão, ou uma tirada daquelas, 'de gênio', ou de humor, demonstrando, nessas cenas, sua espontaneidade natural, na externalização de seus sentimentos, por meio de sua linguagem corporal. Se, por um lado, a espontaneidade é presença 
natural na ação de algumas pessoas, por outro lado, é possível, com trabalho e treino, desenvolver essa capacidade.

Acredito que a presença do narrador oral se dá pela capacidade de interação suscitada pelo conto, sendo articulada pelo que fica entre o contador e o ouvinte, ou seja, a significação do conto, que se dá por meio da construção de imagens e emoções instigadas pelas palavras do texto, trazidas pela memória e externalizadas de forma espontânea.

Por enquanto, uma breve conclusão ajuda a situar o leitor nesse longo percurso: de que o contador de histórias, sujeito dessa pesquisa, é aquele que se assume como contador de histórias que busca um conhecimento para se construir, para entender e ampliar o seu fazer. A descoberta/formação desse sujeito narrador oral se faz com base em uma escolha pessoal, que vem, de preferência, do coração, mas, também, por outras vontades ou motivações pessoais ou profissionais para ser um multiplicador do conto. A escolha pessoal de cada narrador oral o remete à sua qualidade de presença, no contar com, em torno dos elementos apresentados: imaginação, memória, emoção e espontaneidade. Depois de se reconhecer contador de histórias, acolhendo seu estado de presença, o repertório passa a ser o foco de análise do próximo capítulo. 


\title{
CAPÍTULO 4 - ESCOLHA E PREPARAÇÃO DO REPERTÓRIO
}

\author{
Uni dunitêSalamêminguê \\ Um sorvete colorê, uni,duni, tê... \\ Ma-mãe- man-dou- eu- es-co-Iher- es-se- da-qui!
}

Escolher nem sempre é uma tarefa fácil. A condição para a realização de uma escolha depende do acesso e do conhecimento. Conhecer as histórias, no mundo de hoje, exige de cada um a condição de ser, ao mesmo tempo, ouvinte e leitor, considerando que as narrativas são encontradas nas formas oral e escrita (sem desconsiderar a existência de outras linguagens narrativas), pelo menos em sua maioria. Isto faz de todo contador de histórias um ouvinte e/ou um leitor, dependendo de seus objetivos e acessos, tanto aos contos orais quanto aos escritos. Nesse sentido é possível afirmar que, quem conhece poucas histórias fica limitado em suas escolhas.

Assim como não defendo um tipo específico de contador, também respeito o repertório de cada um, compreendendo que as escolhas passam por critérios individuais e que cada contador é responsável por elas. Nesse sentido, este capítulo oferece minhas experiências que serviram de orientação para a descoberta de contadores de histórias, em cursos e oficinas, procurando oferecer contribuições nos seguintes campos: nos diálogos com a narrativa, entendendo suas relações com 0 contador de histórias aprendiz; nos aspectos que envolvem as escolhas das linguagens utilizadas nas narrações, numa abordagem sócio linguística; numa visão dos contos populares e dos contos autorais da literatura infantil e juvenil no Brasil; e, enfim, em algumas formas de aproximação do texto, na intenção de prepará-lo para contar, antes de tratar dos aspectos da linguagem corporal, que são tratados no último capítulo.

No mundo letrado, grande parte do repertório da humanidade encontra-se registrado, embora ainda existam muitos contos apenas na memória de alguns, à espera de registros. São cada vez de mais fácil acesso, levando-se em conta o uso das tecnologias de informação e comunicação ${ }^{95}$ (TICs).

\footnotetext{
${ }^{95} \mathrm{Em} 2014$, é possível observar que o acesso às novas tecnologias de informação e comunicação alcançou a maioria dos brasileiros. É muito raro encontrar uma comunidade que não tenha contato
} 
Os livros, embora continuem caros no Brasil ${ }^{96}$, são hoje mais acessíveis do que há vinte anos, ou antes, podendo ser encontrados em escolas e bibliotecas públicas, em ONGs e projetos de instituições variadas. O acesso à leitura ainda é insuficiente, pensando na enorme pluralidade de realidades brasileiras. Mas, não há como negar que existem perspectivas de crescimento na área. Uma das formas de comprovação do aumento de leitores é considerar o crescimento do número de editoras que surgem no mercado, tanto em papel, quanto digitais.

Contos populares e autorais se mesclam nas prateleiras de bibliotecas e livrarias. Há que se ter cuidado com versões de contos tradicionais que não trazem uma referência precisa de sua fonte. Do meu ponto de vista, avaliando a importância da história oral como reveladora de identidades, quando um conto é registrado carrega consigo traços de quem o registrou, daí a importância do contador conhecer até mais de uma versão, para escolher ou refazer a sua própria. Falo dessa referência em duas situações: quando se vai registrar um conto oral; e quando se escolhe um conto de tradição para contar. Nunca é demais repetir, a importância de ser claro com seu público e revelar a fonte da história, permitindo ao ouvinte se colocar melhor naquele contexto. Um conto tradicional pode ter várias fontes e vários registros, nem sempre conhecidos.

Por outro lado, quando se trata de investigar e discutir a origem (no sentido de surgimento - origem primeira) de contos populares, considero terreno escorregadio e talvez desnecessário de ser explorado. Se as histórias sempre existiram na humanidade e foram (e continuam sendo) recontadas de diversas formas, não tem sentido a busca por um texto original, sobretudo, quando se tem o sentido de original como "verdadeiro". O sentido de verdade adotado nesta tese vai ao encontro das ideias de Adam Schaff, em seu livro História e Verdade (1986). O autor defende que toda história é sempre o ponto de vista de quem "conta", sendo impossível uma única verdade absoluta. Pontos de vista contrários de uma mesma história podem ser verdadeiros, quando, por exemplo, se conta a história de uma guerra. Assim, desaparecem as estórias, dando lugar às histórias fictícias e/ou "verdadeiras". Portanto, cada texto representa sua verdade, tendo seu valor em cada época e

com as tecnologias de informação e comunicação como: rádio, telefonia, televisão e internet, mesmo que de forma insuficiente.

${ }^{96}$ Considero que os livros são caros, independente dos baixos salários dos professores, cuja realidade atinge a maioria dos estados brasileiros. Reconheço um paradoxo de que os livros são caros porque não se lê muito, sendo a tiragem de exemplares muito pequenas, aumentando os custos. Sem dúvida interferir nesse círculo vicioso é uma questão cultural. 
lugar. Cada versão oferecida pode ser original em sua apresentação. A multiplicidade de significados convive e as identifico como características dos tempos atuais. A origem que coloco em discussão é, simplesmente, se o texto pertence a uma literatura autoral, ou foi recolhido da cultura popular, para com isso, tomar decisões, uma vez que conteúdo e forma com que se apresentam as histórias são transformados, através dos tempos e o contador de histórias tem responsabilidades sobre suas escolhas.

Como exemplo, para esclarecer essa questão, trago uma discussão em torno do tema, que tomou conta do senso comum, tendo uma publicação na revista Veja ${ }^{97}$, há mais de vinte anos, perpetuado polêmicas e preconceitos. A matéria reclamava dos absurdos das letras das cantigas infantis, acusando-as de prejuízos à educação infantil, pois assustavam as crianças, como o 'boi da cara preta' e deseducavam, outras, ensinando a 'atirar o pau no gato'. Para este segundo exemplo musical, a reportagem chegava a indicar uma versão ecologicamente correta da música, bastante conhecida no universo das escolas de educação infantil. Essa não é uma discussão isolada e nem pequena, passando pelas questões de valores, ideologia e preconceito, como mostra llan Brenman (2012). “Existem termos e expressões ofensivos, porém, o contexto em que desabrocham é que lhes dá o caráter preconceituoso" (2012, p. 34). O autor alerta "Um dos temas que abordo no trabalho é a alteração das letras nas cantigas infantis. A força desse movimento pela purificação dessas "tenebrosas cantigas" tem aumentado consideravelmente a cada ano" (ibidem, p.17). É preocupante, pelo fato de ser ideológico e de estar em crescimento, reforçando a necessidade de uma formação crítica.

Pelo que me lembro, quando fui professora de pré-escola cantava com meus alunos Atirei o Pau no Gato em mais três versões ${ }^{98}$, que ofereciam diversão e desenvolvimento crítico para a garotada, que eu saiba, sem prejuízo algum para a formação desses que já são adultos, hoje. Se eles não tivessem conhecimento daquela primeira versão tradicional (não necessariamente original), como saberiam que as outras são transformações subsequentes? Conhecer e conviver com

\footnotetext{
${ }^{97}$ Reportagem que repercutiu na época, sendo bastante comentada, em diversos ambientes. A referência exata da edição não vem ao caso, uma vez que o exemplo é apenas ilustrativo e, relatos como este aparecem em diversos meios de comunicação, gerando preconceitos, muitas vezes sem intenção.

${ }^{98}$ Versão ecológica (apresentada no livro de llan Brenman); versão rock'n roll (a letra tradicional na música "The Wall", do Pink Floyd); versão erudita (inventada por mim para brincar com o politicamente correto, quando começou a aparecer a discussão).
} 
múltiplas versões pode ajudar a formar um senso crítico que interfere positivamente nas escolhas, gerando autonomia.

Assim, o primeiro e, talvez, o critério mais importante para escolher uma história para contar, seja conhecer muitas histórias, de livro e de boca, se apaixonar tanto por uma delas, que dá vontade de sair contando, imediatamente. Como quando a gente conta um caso interessante que aconteceu em um sonho ou que tenha mesmo acontecido na realidade. Em minha experiência, aquela história que leio, ou ouço, apenas uma vez, e consigo recontar com entusiasmo, descrevendo alguns detalhes, certamente é uma história que "me escolheu", merece ser estudada e colocada no repertório. Parece que a história fica gritando dentro da gente, pedindo para sair! Já me identifiquei com vários contadores, em relatos de experiências, que compartilham essas mesmas formas de escolha.

Pensar no tipo de plateia também pode ajudar o contador a escolher sua história. A arte educadora Ana Mae Barbosa (2008), em sua abordagem triangular para o ensino de arte na escola ${ }^{99}$, mostra que uma obra de arte só se complementa na presença de um espectador que completa seu significado. Neste sentido, o contador de histórias, sujeito dessa pesquisa, é alguém que conta "com" outro, que significa e entende cada termo, junto ao narrador, se apresentando como linguagem de arte. Faz parte da escolha ler e se imaginar contando, procurar conhecer textos diferentes, não só de tipos diversificados, mas para idades variadas, inclusive aqueles populares, para os quais não há indicação específica de idade.Ou, por outro lado, se especializar em um tipo único de plateia, é uma experiência interessante, que mostra não ser possível mostrar um caminho, pois existem muitos. Na disciplina de Núcleo Livre, na turma de 2011, duas alunas (dos cursos de enfermagem e pedagogia) queriam saber como escolher histórias para contar em hospitais. Com base em minha experiência no projeto "Contando com Vitória ${ }^{100 ", ~ p o r ~ m a i s ~ d e ~ t r e ̂ s ~}$ anos, pudemos, então, mapear o espaço e os objetivos das contadoras, levantando critérios (que podem ser modificados) para as pesquisas das histórias delas.

\footnotetext{
${ }^{99} \mathrm{~A}$ abordagem Triangular no ensino de arte proposta por Ana Mae Barbosa é pautada no tripé: fazer, assistir e contextualizar. Tem sido aceita e aplicada em todas as linguagens artísticas, embora tenha sido pensada, primeiramente, nas artes visuais. Vários artigos sobre o tema podem ser encontrados no portal de periódicos Capes e nas obras da autora.

100 Projeto de extensão de Faculdade de Medicina da UFG, com apoio do Grupo Gwaya, como contação de histórias, todas as sextas feiras, na pediatria do hospital Araújo Jorge (conhecido como hospital do Câncer), em Goiânia, com participação mensal, de 1995 a 1998, retomando outras poucas atividades, em 2003.
} 
Nessa mesma turma do exemplo anterior, percebi que, quando a experiência do contador ainda é pequena, as histórias mais curtas, com estrutura convencional e sem diálogo, são mais fáceis. Dominar a estrutura de um texto é essencial para o narrador, pois é o início da preparação para contá-la. Se o texto tiver falas das personagens é melhor que sejam isoladas, não contendo diálogos, em um primeiro momento. Essa percepção me foi possível, por ter material de comparação entre a primeira história, que contaram de improviso, e a outra, que foi preparada. $O$ resultado que mais me chamou a atenção foi o enriquecimento daqueles que ficaram insatisfeitos com seu improviso, sendo que a escolha de textos e a preparação (entender a estrutura) foram os responsáveis pela conquista, declarado em auto avaliação oral coletiva, ao final do encontro. Porém, nunca faço disso uma regra. Há que se admitir que as experiências individuais revelem direções múltiplas, que podem surpreender e, até, contradizer este pensamento, e alunos nos surpreendem, quando estamos dispostos a ouvi-los.

Observo, em outras turmas, que alguns contadores têm mais facilidade, sem ter o menor problema com diálogos, caracterizando os personagens de modo criativo, com gestos e timbre de voz. Essas características foram notadas em pessoas que são consideradas ótimas contadoras de piadas. São aquelas que mobilizam as pessoas à sua volta, formando uma plateia cativa, em qualquer lugar que estejam provocando descargas de risos e gargalhadas. Em grande parte, são pessoas que exercem certo tipo de liderança e estão acostumadas a ser o centro das atenções, com grande capacidade de improvisos.

A variedade de linguagens advindas da diversidade cultural brasileira faz com que se multipliquem as possibilidades de escolha do contador de histórias, considerando, também, a necessidade de conhecê-la, para fazer uma opção coerente com seus objetivos. Ao tratar da escolha e preparação do repertório de um contador, considero o conhecimento como ponto de partida, e a responsabilidade do seu fazer, como ponto de chegada, portanto, outro fundamento.

Ao abordar sobre o repertório existente é preciso refletir sobre as diferentes linguagens presentes na sociedade e na escola, e como essas interferem nas escolhas dos contadores, com suas consequências. Para essa discussão, faço uma aproximação com a abordagem sociolinguística, para posteriores tomadas de decisões. Conhecendo as diferenças entre as linguagens, a dinamicidade da língua 
e de que maneira isso é visto na escola, cria-se condições para o contador escolher com a autonomia e a responsabilidade que lhe cabe.

\subsection{Definindo um repertório: um estudo de sociolinguística}

As pessoas contam as histórias e canções de que gostavam quando elas próprias eram crianças,

de modo que quem escolhe as histórias para as crianças de hoje são as crianças de ontem.

Kornei Chukovski

Ao mergulhar no infinito universo das histórias, de boca e de livro, surgem questões sobre: o que contar? Como escolher um conto em um universo tão imenso? Como o contador de histórias contemporâneo pode construir o seu repertório de contos? Que tipo de conto é melhor para ser contado? O conto popular ou a história autoral? Entre as histórias orais e as autorais há alguma diferença? Como conhecer e/ou onde pesquisar narrativas que atendam ao objetivo do contador?

A definição de um repertório de histórias a serem contadas é tão amplo, quanto a própria quantidade de contadores. Entretanto, a proposta, neste contexto, é priorizar o contador de histórias no ambiente escolar, atendendo as especificidades de uma educação que valorize a arte como componente curricular importante na formação do ser humano, em qualquer idade e fase de desenvolvimento.

Verifica-se, neste momento, a necessidade de abordagem de algumas características das linguagens oral e escrita, em seus contextos, identificando os seus usos e valores, por meio de conceitos de norma popular, norma padrão e norma culta, utilizando as bases de estudos da sociolinguística, mais especificamente, a sociolinguística educacional. A escolha teórica se dá em razão da aproximação com a antropologia e da afinidade de pensamentos e propostas de ações indicadas. Embora faça uso de alguns dos conceitos da área, sem a intenção de me aprofundar no tema, não há uma definição absoluta no uso das terminologias, uma vez que os autores da área nem sempre utilizam, exatamente, os mesmos termos. 
Ouvimos histórias com linguagens regionais, com sotaque, vocabulário e gramática bastante variada e lemos histórias que utilizam a norma padrão oficial do país. Se as linguagens são diferentes e coexistem, qual delas deve-se escolher para contar? A linguagem escrita deve ser preservada pelo contador, em sua narração? Até que ponto? O que acontece com a opção de recontar uma história, preservando sua oralidade, na qual a forma de falar se distancia da norma padrão do português que a escola ensina? Qual a linguagem mais adequada?

O objetivo, neste momento, é esclarecer pontos que considero essenciais na escolha da linguagem adotada para se contar histórias, do ponto de vista da educação. A intenção não é cercear ou indicar alguma falha, e sim, apoiar a opção do contador em sua consciência, ou seja, quando um contador assume uma posição é esperado que ele saiba o que está fazendo, pois disso dependem as consequências do seu trabalho, sejam elas positivas ou não.

Aprendi a usar a multiplicidade cultural brasileira, com sua grande variedade linguística, observadas nos sotaques, no vocabulário, na gramática, nas brincadeiras, nos contos e cantos de regiões diversas. A sociolinguística mostra que não se trata de falar errado. Em cada local, a entonação, o vocabulário e até a conjugação mudam, mas a interação ocorre, mesmo com as diferenças, ou melhor, inclusive por meio delas. O Goiano praticamente desconhece o plural em seu sotaque mais interiorano, então é comum ouvir "os menino val"...

Há que se considerar a discussão que envolve o ensino da língua portuguesa, em seus questionamentos sobre a valorização ou não, e em até que ponto se deve permitir ou incentivar o uso de uma linguagem oral, popular ${ }^{101}$, no ambiente escolar. Nós, professores universitários, esbarramos, quase todos os dias, nas dificuldades de leitura e escrita de nossos alunos, que são reais e alarmantes. Se alguns alunos chegam à universidade com essa fragilidade, quer dizer que se arrastaram por todo o ensino básico sem conseguir vencer o problema do domínio da leitura/escrita, desde o início de seu letramento. O problema vai sendo adiado, até ficar sem solução. Na maioria das vezes, o que percebi, em dez anos de experiência como professora, na Licenciatura, foi que aqueles alunos que têm muita dificuldade na escrita, também não conseguem se expressar verbalmente, e nem tão pouco,

\footnotetext{
${ }^{101}$ Seria considerar as falas de cada local das regiões do Brasil, com suas peculiaridades, sotaques, vocabulários, conjugações diferentes, às vezes, quase um dialeto.
} 
corporalmente, geralmente por falta de estímulo ou oportunidade. Mas não é tão simples assim.

É fácil perceber o preconceito com aqueles que não dominam a norma padrão da língua ensinada na escola que, por sua vez, é pautada em gramáticas e normas da língua portuguesa, da qual são conhecedoras apenas as classes mais abastadas, por terem sido por eles elaboradas, como mostra Cavalcanti (2011, p.1). Antes de condenar alguém por falar dessa ou daquela maneira, é importante entender que a língua é dinâmica, estando em constante transformação, sendo culturalmente construída, tendo suas especificidades e variações em suas formas. Silvana Araújo destaca que é veiculada

(...) na escola uma norma linguística anacrônica, distante da norma realmente utilizada por falantes cultos brasileiros, causando uma dificuldade até mesmo para alunos que tem o contato com a cultura letrada em seus convívios familiares. Assim, se na passagem de um uso culto na oralidade para um uso padrão na escrita há este conflito, o que dizer, então, do confronto entre essas duas normas e os falares populares? (2008, p. 6/7).

A dificuldade de lidar com essa diversidade é histórica, sendo comum observarmos professores e alunos criticando a forma de falar, um do outro, apontando, pejorativamente, os falantes de classes econômicas mais baixas, como se eles não soubessem e/ou não pudessem alcançar a fala de uma elite. Segundo as pesquisas de Silvana Araújo, a norma padrão da língua brasileira, que é estudada nas escolas:

\footnotetext{
foi pautada nos usos de literatos portugueses dos séculos XVI a XIX, e de brasileiros cultos do século XIX e início do século XX, dentro de um projeto de branqueamento da população brasileira, negando-se a miscigenação típica em um país com múltiplas culturas e etnias; estando, assim, a escolha da norma padrão de acordo com um projeto da elite brasileira do início daquele século (FARACO, 2002 e PAGOTTO, 1998) $(2008$, p. 3).
}

Para os autores da sociolinguística, no entanto, não existe fala certa ou errada. Depende da referência de quem ouve e/ou fala. Bortoni-Ricardo (2005), ao estudar as diferenças linguísticas entre a zona rural e os centros urbanos, explica que, neste último, a padronização é maior, estimulada por várias agências reguladoras, como: imprensa, obras literárias e escolas, enquanto na zona rural, a dificuldade de acesso entre as comunidades gerou maiores mudanças, comprovando a dinâmica da língua. Desta forma, a língua é concebida como um fato 
cultural, segundo Novaes (2011), e, como a cultura é múltipla e dinâmica, é natural a existência das variações linguísticas.

Essa variação linguística pode ser mais notada na norma popular, com sua liberdade e variações constantes entre os falantes das comunidades, sendo diferente da norma padrão, em que as variações são orientadas por especialistas no assunto, por isso, mais lentas. Novaes (2011) esclarece que "nesse sentido, norma não se confunde com o correto, com norma prescritiva, mas é o normal, o comum, a realização linguística que a comunidade espera de seus falantes" ibidem, (p. 5) Assim, a autora acrescenta: "o que existe na verdade, tanto na língua oral quanto na escrita, é sempre a diversidade e a variação; um conjunto de dialetos e de normas ao mesmo tempo" ibidem, (p. 7). Mas, o que observo, sobretudo nas escolas, encontra ressonância na fala de Cavalcanti: "é que, muitas vezes os alunos usuários das variedades populares são discriminados em função da sua maneira de falar" (2011, p. 1).

Por outro lado, segundo Mendonça: "para os sociolinguistas brasileiros, metodologicamente, norma culta é considerada a norma utilizada por falantes que possuem nível universitário" (2007, p. 185). Ao observar a fala dos universitários, hoje, verificamos uma enorme distância de qualquer prescrição gramatical, não só pela presença de gírias, mas, sobretudo, nas concordâncias e falta de plurais. Araújo esclarece: "A fala brasileira dita culta está distante do artificialismo existente na prescrição gramatical adotada pela escola" (2008, p. 3), assim sendo, não é essa a norma da língua ensinada na escola. E o resultado é a falta de domínio da própria língua que é ensinada.

Entretanto, incentivar o aluno (ou o contador de histórias) a perceber diferenças nos fatores linguísticos que interferem no uso da língua, pode minimizar os preconceitos linguísticos, na medida em que o aluno aprende a necessidade de adequar sua linguagem às diversas situações de comunicação que tiver que enfrentar. A comunicação e a interação (no caso da obra de arte) permitem usos diferentes de linguagens, para situações variadas.

Portanto, do meu ponto de vista, o contador pode enriquecer muito seu trabalho quando, antes de escolher a linguagem da história que quer contar, compreender o que os linguistas pensam a respeito e como eles encaram o problema do uso dessas linguagens, sobretudo, na escola. Isso dá possibilidade de o contador se posicionar, sabendo o uso que faz de sua linguagem. 
Como contadora de histórias, acho importante não só conhecer a discussão, mas valorizar as diferentes formas dos falantes, sem eleger uma melhor que outra, simplesmente, reconhecendo suas diferenças. Aliás, o narrador oral pode brincar com sotaques diferentes, minimizando preconceitos e ampliando vocabulários e entendimentos de falantes e ouvintes. Sua escolha também não precisa ser única, mas saber onde utilizar cada linguagem permite alcançar melhor os ouvintes. $O$ conhecimento das variações linguísticas permite aos contadores maior variedade nas escolhas das formas de fala e/ou escrita, se adaptando a cada circunstância, considerando o contexto de sua produção, adequando recursos expressivos, variedade da língua e estilo, às variadas ocorrências.

Seja escrita na linguagem literária, que obedece à norma padrão ensinada na escola, ou a linguagem oral, com o sotaque específico de uma região, a história escolhida para contar deve mobilizar o contador por todos os seus sentidos. Costuma-se dizer que o conto escolhe o contador, cada um à sua maneira. Se ficar atento, vai perceber que "ele pisca pra você"! Já usei muito essa expressão, em sala de aula e, também, encontrei outros contadores que também usam esse termo.

Em qualquer das escolhas, penso que a fonte daquele conto precisa ser revelada, pois é direito do ouvinte saber onde encontrar tais referências.

Chamo a atenção para possíveis problemas de autoria, comuns de ocorrerem nos tempos atuais. Se a internet, por um lado, propicia informações imediatas, não é sempre confiável, sendo necessário cuidado. É comum encontrarmos textos com autorias alteradas, no ambiente virtual, exigindo do professor/pesquisador sério uma responsabilidade nas informações que divulga. Gosto de pensar que, na arte, podemos tudo, que a arte está, sobretudo em quebrar regras, para experimentar novas criações. Assim, aceito a liberdade de alterar um texto em qualquer direção, mas com a condição de esclarecer o que foi feito. Não se trata de não poder fazer isto ou aquilo, trata-se de esclarecer o que foi feito ao espectador. Este, sim, merece a fidelidade e dedicação do artista à sua obra.

Sejam contos populares, literários, nacionais ou mundiais, orais ou escritos, na norma padrão ou na norma popular, quanto mais o contador conhecer, melhor para escolher. Este conhecimento será aprofundado nos subitens subsequentes, discutindo características e estruturas dos contos de linguagem oral e onde encontrá-los; critérios observáveis sobre a produção da literatura infantil e juvenil 
brasileira autoral, com a intenção de despertar o interesse e a pesquisa no contador em construção.

\subsubsection{Contos populares: um repertório sem fim...}

Tomando emprestada a ideia da "História sem fim", quando o "nada" tomar conta de tudo, as histórias se acabam. Contudo, enquanto existir boca para contar e ouvido para escutar, as narrativas continuarão a existir, preenchendo imaginários e despertando emoções. Sobretudo, as histórias que nascem "da boca do povo" e vão sendo inventadas, espalhadas, recriadas, consagradas: são os contos populares, cuja origem se perde no tempo, sendo impossível precisá-la.

Walter Benjamin (1975), em seu texto: "O narrador", faz referência aos contadores de histórias com base em duas vertentes: do camponês sedentário, que tem de perpetuar sua cultura, e do viajante, que traz sempre novidades de outros lugares. Assim, foi se tecendo essa imensa teia de contadores e contos, que hoje se espalham por todos os continentes. Entendo essas vertentes se estendendo por todos os continentes onde há vida humana e interação comunicativa entre os povos. As histórias da humanidade foram e continuam sendo construídas entre o novo e o velho, entre o absurdo e a realidade, entre a verdade e a fantasia, polaridades ${ }^{102}$ que alimentam a criatividade humana e podem ser percebidas de diversas formas, entre diferentes culturas.

São narradas pelo povo, por meio da oralidade, como se diz: "Da boca do avô para o ouvido do neto". Hoje, são conhecidas como contos populares. Pertencem ao povo, nasceram do povo, fazem parte da cultura oral ou da cultura popular ${ }^{103}$, reconhecidas como importantes, por parte dos acadêmicos. Alguns mais, outros menos conhecidos.

Para esta pesquisa, considero que uma das principais características dos contos populares consiste em sua autoria desconhecida. Foram registrados de diversas maneiras, desde desenhos nas cavernas, esculturas de totens, hieróglifos

\footnotetext{
102 Polaridade, aqui, não tem sentido de fragmentação, mas se enraíza em um pensamento mais profundo da presença de forças opostas, como motor de transformação, corroborando com a abordagem metodológica desta investigação.

I03 Ver: Roberto DA-MATTA (1981); SANTOS (2011); ABREU (2010). O aprofundamento do tema e sua referente conceituação são apresentados no primeiro capítulo, por considerar o conhecimento sobre a cultura popular como um dos fundamentos do contador em sua descoberta.
} 
egípcios, até a forma escrita que existe hoje, se estendendo às possibilidades tecnológicas do mundo contemporâneo, que registra a imagem em movimento (cinema, vídeo, etc.).

Gislayne Matos e Inno Sorsy ${ }^{104}$ (2009) variando critérios e métodos em suas análises, anotam não haver um consenso para uma classificação dos contos populares. O resultado é uma falta de concordância entre os folcloristas e outros pesquisadores. Contudo, as autoras oferecem muitos exemplos, que pude aproveitar na exposição que se segue ${ }^{105}$.

Para o objetivo aqui presente, uma classificação rígida contradiz, não só as bases da formação em construção, como não atende 0 alvo de conhecer a variedade existente de contos populares. Assim, o que se segue não se vincula a uma classificação específica, simplesmente procura apresentar uma maior variedade de tipo ou gêneros literários e suas características, atendendo ao objetivo de apresentar um repertório a ser conhecido, para ampliar as possibilidades das escolhas de cada contador.

Um breve percurso dos contos da humanidade, sobretudo daqueles que se perpetuaram e continuam encantando contadores e ouvintes, pode ser encontrado em minha dissertação de mestrado ${ }^{106}$, embora em uma perspectiva apenas ocidental. Assumindo essa falha, pretendo reconstruir o percurso, ampliando-o, ao considerar outras influências sem hierarquia de importância ou qualidade, pondero agora sobre as extensões dos contos indígenas, africanos e mesmos os orientais, em sua diversidade.

Nesse sentido, o mito pode ser considerado a mais antiga das narrativas ${ }^{107}$, dos registros já encontrados. Na pré-história, a preocupação maior do homem era a sobrevivência. Seu pensar e seu fazer estabeleciam-se na sua relação com a natureza. Era preciso observá-la para dominá-la e transformá-la a seu favor. Observando os fenômenos naturais, até então inexplicáveis, o homem primitivo recorre à magia como forma de controlar estas forças superiores e, através da sua

\footnotetext{
${ }^{104}$ Duas contadoras de histórias, brasileira e inglesa, respectivamente, escreveram juntas o livro: "O ofício do contador de histórias", Rio de Janeiro, Martins Fontes, 2009.

${ }^{105}$ Entretanto, deixo claro que não assumo nenhuma das classificações ou categorizações utilizadas pelos diversos autores que trago para o diálogo, por não ser este o foco.

${ }^{106}$ Defendida na Unicamp, em 2000, na área de Estudos do Lazer, sob orientação do profo $\mathrm{Dr}$. Jocimar Daólio, com o título: Dos contadores de histórias e das histórias dos contadores.

${ }^{107}$ Para aprofundar o conhecimento e pesquisar sobre mito e/ou mitologia, indico os estudos de Joseph Campbell, em "O Poder do Mito: Joseph Campbell com Bill Moyers. São Paulo, ed Palas Atenas, 1990. O livro é acompanhado de quatro DVDs, com as entrevistas.
} 
intuição, passa a reverenciá-las e a divinizá-las, dando origem ao mito. "O rosto do mundo se unifica provisoriamente no mito, primeira tentativa de acomodação global e que visa menos uma 'interpretação' do que certa organização da eficácia para a sobrevivência humana" (LATERZA e RIOS, 1971, p. 18).

Há que se considerar que, anterior ao mito, a experiência dos grupos humanos já havia acumulado na memória e nos hábitos coletivos uma grande produção de instrumentos e uma massa de conhecimentos empíricos. Entretanto, quando o homem se eleva a um saber (mítico), aparece um duplo movimento da cultura - a transformação da natureza e a humanização do homem. (VAZ, 1966). A relação mítica com o mundo permitia ao homem acreditar não só no que via, mas no que imaginava, permitindo muitos registros, em lugares e tempos diferentes. A mitologia, geralmente, trata de temas arquetípicos da existência humana, tornandoos fundamentais.

A coleção Mar de Histórias, de Aurélio Buarque Ferreira e Renan Rónai (1998), mostra o primeiro registro escrito de um conto, que data de XIV a.C., no Egito. O conto tem um estilo policial, em que o rei acaba entregando a mão de sua filha ao ladrão, de tanto este conseguir escapulir, espertamente, das armadilhas preparadas pelo soberano.

Homero, no século VIII a.C., recolhendo contos, mitos e lendas da oralidade, deixou registrada a formação de um povo, a constituição da cultura grega. llíada e Odisseia, por exemplo, durante centenas de anos, foram utilizadas pela educação, por meio de recitações de seus conteúdos. Heródoto foi o primeiro narrador grego, e ainda consegue suscitar espanto e reflexão em seus relatos, mesmo depois de milênios.

Os Aedos são outro tipo de contadores de histórias, que cantavam e/ou recitavam versos, com composições épicas e religiosas, por volta do século IX a.C. (FERREIRA e RÓNAI, 1998). Os hebreus desenvolveram um gênero literário de recontar histórias, interpretando-as e aprofundando-as, encontradas nas parábolas da Bíblia Sagrada. Na Idade Média, provavelmente, os trovadores ocuparam os lugares dos Aedos, pois cantavam trovas e historietas de acontecimentos cotidianos, para educar e divertir.

Fora do contexto europeu (maior influência em nossa cultura) existe um enorme repertório de contos de ensinamento, circulados em muitas partes do 
mundo. Um dos exemplos mais ricos e difundidos em nossa cultura, "As mil e uma noites", onde estão as histórias de Ali Babá e Aladim, pertencem à cultura árabe.

Os contos da tradição Sufi, da cultura hinduísta, também merecem ser evidenciados, por serem, ainda, utilizados por vários povos, sendo contos de ensinamento que tratam de questões básicas do ser humano e continuam sempre atuais. Este registro encontrado na literatura hindu, do século $V$ a.C., reflete a concepção védica, bramânica do mundo, anterior ao budismo. Os sacerdotes da nova religião descobriram, no conto, um grande meio de convencimento para suas doutrinas. Os assuntos, que vão do cotidiano simples ao fantástico mais estranho, alimentaram a imaginação da humanidade, durante séculos, transformando-se e perpetuando-se, sendo encontrados, hoje, em diferentes versões. Essas lendas e contos estenderam-se por toda a China e, afastando-se do conteúdo religioso, espalharam-se em várias versões - chinesa, persa, grega, latina... - infiltrando-se na tradição de todos os povos (FERREIRA e RÓNAI, 1998).

Durante a Idade Média, quantos contos devem ter circulado nas bocas e ouvidos, em todas as comunidades do mundo? Quantos devem ter sido queimados, perdidos nas ações do tempo, ou na memória dos anciãos, cada vez menos ouvidos nos tempos atuais? Como país colonizado que somos, encontramos traduzidos para o português, uma grande diversidade de contos, advindos de povos de lugares diferentes, explicando a multiplicidade existente.

Mais especificamente na Europa, com o advento da imprensa, os contos começaram a ser mais registrados. No final do século XVII, o rei Luiz XIV encomendou 'Os contos da Mamãe Gansa' a Charles Perrault, que se incumbiu de coletar as histórias da oralidade de sua cultura, reescrevendo-as com mais suavidade (MAGALHÃES, 2010) e adaptando as morais das histórias para que servissem à educação das crianças da corte francesa. Esta questão permanece ainda hoje, muito bem observada por Maria Tatar, quando diz que "estamos envolvidos com a ideia de que a literatura moral pode produzir bons cidadãos" (TATAR, 2004, p. 11). Hoje, esta moral é percebida e questionada de várias formas.

Com a percepção da necessidade de se considerar a diferença entre as pessoas como ponto de partida para as relações humanas, uma única moral da história soa como imposição de uma forma igual. A liberdade de interpretação e entendimento das mensagens das histórias é o que se espera de uma educação para a autonomia e criatividade. 
No início do século XIX, com objetivo de registrar os contos orais da Alemanha, os irmãos Grimm, filólogos e historiadores coletaram e publicaram por volta de 200 contos, preservando as características linguísticas que o povo da época imprimia naquelas narrativas.

Esses contos ainda existem, "poucos contos de fadas gozam de tão rica sobrevivência literária, cinematográfica e musical, quanto Cinderela" (TATAR, 2004, p. 37). Segundo a autora, a primeira Cinderela data de 850 d.C., chamava-se Yehhsien, registrada por Tuan Ch'engshih, de origem chinesa. É uma criatura humilde, como nas Cinderelas ocidentais. Existe uma infinidade de versões, em diversas linguagens e países, na literatura, no cinema e no teatro, comprovadas em dissertações de mestrado e trabalhos acadêmicos. Boa parte da edição dessas coleções povoaram a infância do brasileiro, a partir do início do século $X X$, e final do anterior. Era o acesso que se tinha na época, bem diferente da quantidade de oferta do mundo tecnológico e digital.

Na Dinamarca, no mesmo século XIX, Hans Christian Andersen publicou uma coletânea de contos, tanto de sua autoria, como recolhidos do folclore. Quem não se lembra de O Soldadinho de Chumbo ou O Patinho Feio! Grande parte desses contos, registrados nessa época, pertence ao gênero fantástico, estudado pela área de letras, envolvendo os contos de fadas ou contos maravilhosos. Suas fórmulas se expressam na presença de fadas e/ou bruxas, nos contos de fadas, e pela presença de um elemento mágico, no conto maravilhoso: anel, tapete voador, lâmpada mágica, botas de sete léguas, etc. São capazes de alcançar emoções profundas nos ouvintes, não só infantis, pois se "destinam à alma humana", como revelam Matos e Sorsy (2009).

Florestas encantadas, reis, rainhas, príncipes, princesas, sapos, bruxas, fadas, duendes, torres, lagos, mares, palácios, heróis, cavalo alado, caminhos coloridos, seres estranhos, objetos com vida...

Assim é o universo dos contos maravilhosos. Povoado pelo mágico, pelas metamorfoses, pelos elementos sobrenaturais, pelos personagens bizarros ou fascinantes, que se entrelaçam numa estrutura complexa. Seu tema central é sempre a luta entre o bem e o mal como meio para restabelecer a harmonia perdida (MATOS e SORSY, 2009, p. 75)

Por esta possibilidade de reestabelecimento, o conto de fadas é essencial na formação da pessoa. Apesar das sérias críticas às análises do psicanalista Bruno 
Bethelheim $^{108}$, concordo quando ele diz que o conto de fadas é um espaço para vivência de emoções, impossíveis no mundo real, mas que podem fortalecer o indivíduo por sua vivência, no mundo imaginário.

Maria Tatar (2004) apresenta um rico estudo sobre contos de fadas, pesquisando, além de ilustrações belíssimas, de artistas de várias épocas, retratando os contos, em várias versões, comentando essas narrativas, contextualizando-as e apontando comparações.

\begin{abstract}
Como nossos ancestrais, que ouviam essas histórias ao pé do fogo. Em tabernas e quartos de fiar, continuamos a ficar petrificados por histórias sobre madrastas malvadas, bichos-papões sanguinários, irmãos rivais e fadas madrinhas. Para nós, também, as histórias são irresistíveis, pois oferecem oportunidades para falar, debater, deliberar, tagarelar e conversar fiado interminavelmente, como faziam as velhas comadres de quem, ao que se diz, essas histórias vieram. E a partir do emaranhado dessa conversa e tagarelice, começamos a definir nossos próprios valores, desejos, apetites e aspirações, criando identidades que nos permitirão produzir finais para sempre felizes para nós e para nossos filhos (TATAR, 2004, p. 15).
\end{abstract}

Pode-se concluir que as histórias nos colocam em contato com as imagens e os sentimentos do mundo, numa possibilidade infinita, ampliando nosso conhecimento e, consequentemente, as oportunidades de escolha. Portanto, essenciais para a formação do ser humano.

Para que algumas versões literárias autorais de contos de fadas façam maior sentido, as versões tradicionais passam a ser essenciais no conhecimento das crianças e jovens do mundo de hoje, tanto para realização de intertextos, como para comparações entre versões tradicionais e novas. Essas versões são encontradas na literatura contemporânea e, às vezes, na oralidade, fazendo parte do imaginário popular, auxiliando na compreensão da multiplicidade de possibilidades coexistentes.

Segundo Afonso Romano (2011), em sua contribuição para o livro organizado por Benita Prieto, sobre Contadores de Histórias:

Os romances foram uma recriação das narrativas orais. Por outro lado, os irmãos Grimm na Alemanha, o dinamarquês Hans Christian Andersen e os romancistas, como Alexandre Dumas, Walter Scott e Jose de Alencar, foram buscar nas lendas, na história, no folclore, o imaginário coletivo (ROMANO, 2011, p. 16).

\footnotetext{
${ }^{108}$ Para aprofundar o assunto, consultar também: Alessandra Giordano (2007); Bruno Bethelheim (1984); Margot Sunderland (2005); Nancy Mellon (2006).
} 
Além dos contos de fadas e romances, que inspiram o narrador oral na busca por um repertório, as fábulas, apólogos e contos de animais, segundo esse autor. são inspirados nas mazelas da humanidade, se mantendo atuais, por isso. A característica de moral da história também é uma constante, sobretudo, nas fábulas em que os animais vivenciam ações humanas, e sempre foram amplamente exploradas na educação. Há indícios de que nasceram na Ásia Menor, de lá teriam migrado para as ilhas gregas, passando pelo Egito e Índia, encontrado na Panchatantra, o livro de contos mais antigo do mundo (MATOS e SORSY, 2009).

As fábulas de Esopo, escravo grego dos séculos IV e III a.C. são, ainda hoje, bastante conhecidas, assim como as fábulas de La Fontaine, registradas por volta do século XVII e difundidas ainda hoje. Uma característica marcante que pude observar é a diferença entre as fábulas ocidentais e orientais. No ocidente uma única moral de história é utilizada, quase como verdade absoluta, ou como valores maiores a serem perseguidos. Por exemplo: a moral, na história "Os três porquinhos", é: "primeiro o trabalho, depois a brincadeira!". Então, não podemos trabalhar brincando? E quem não tem ou não pode trabalhar, também perde o direito a brincar?

Nas fábulas orientais os ensinamentos são abertos, absorvidos pelos ouvintes, segundo suas próprias capacidades. Malba Tahan (1964) demonstra isso em: "Uma Fábula sobre a Fábula", citada, também, por Giordano (2007), para explicar como as histórias chegam às pessoas. Neste exemplo, o próprio conto deixa claro que as perspectivas de entendimento são múltiplas, pois a mensagem não é direta. A "Verdade" cismando que queria entrar no palácio, faz várias tentativas, sendo negada, em trajes transparentes, anunciada como "Verdade". É, novamente, negada em trajes grotescos de pele de animal, sendo apresentada como "Acusação". Quando finalmente é aceita, vestida em suas mais ricas vestes, sendo apresentada como "Fábula". "E foi assim que a "Verdade", anunciando-se como "Fábula", é aceita no palácio do Califa.

Outro gênero amplamente explorado no repertório dos contadores contemporâneos são as lendas, que, apenas na aparência, se aproximam dos mitos, talvez pela intenção de explicar a origem das coisas. "São sempre ligadas a uma crença originada em um fato até certo ponto real” (MATOS e SORSY, 2009, p. 87). 
$\mathrm{Na}$ literatura brasileira, hoje, encontramos muitas lendas indígenas, anteriormente recolhidas e recontadas por folcloristas, como Câmara Cascudo, Regina Lacerda, em Goiás, e outros de igual importância. Hoje a realidade é outra e existem muitos povos indígenas que se preocupam com o registro e manutenção de suas histórias. Já é possível, inclusive, a observação de traços característicos de determinadas histórias. Nas lendas de amor, por exemplo, há sempre uma consequência, quando um amor se torna impossível, este se transforma em um elemento da natureza para simbolizar aquele amor ${ }^{109}$. O indígena Daniel Munduruku ${ }^{110}$ é representativo dessa realidade, por seu trabalho de registro, não só de lendas e histórias da tradição Munduruku, como, também, de outras etnias indígenas, tendo mapeado várias informações de tribos brasileiras, afirmando haver mais de 170 línguas ou dialetos falados no Brasil, no final do século XX (MUNDURUKU, 1996).

Outros tipos de contos populares podem ser levantados, na intenção de mostrar a diversidade de estilos: contos cumulativos e histórias sem fim (que trabalham a lógica, o ritmo e a memorização das crianças pequenas); contos de assombração e contos de fazer medo; contos de demônio, contos de morte; facécias, contos humorísticos, anedotas e piadas; e os causos. As autoras Sorsy e Matos dão exemplos em uma preciosa seleção para contadores, no livro: O ofício dos contadores de histórias (2009). Luciana Hartmann (2011), em sua pesquisa com os contadores de histórias da tríplice fronteira, apresenta outra classificação, com base nos contos pesquisados: de assombração, enterro de dinheiro, causos de guerra, histórias de vida, anedotas. Cada pesquisador em seus métodos, objetivos e resultados, certamente, apresentarão diferentes categorizações, que do meu ponto de vista, não precisam ser aceitas como absolutas, admitindo diferenças e semelhanças, por vezes, simultâneas.

No Brasil, os contos populares são de uma riqueza extraordinária, se construindo com a influência dos europeus, indígenas africanos e orientais, desde o início de sua história. Com essa miscigenação, brotou um povo rico em sua diversidade cultural, alterando modos de ser e fazer, reinventando histórias de todos

\footnotetext{
${ }^{109}$ No início do grupo Gwaya, fizemos uma pesquisa de lendas indígenas de amor, onde essa característica foi percebida e discutida pelo grupo. Não há como garantir que todas sejam assim, mas que existe esse traço em muitas delas.

${ }^{11}$ Índio da etnia Mundurucu, filósofo, historiador, psicólogo, com doutorado em Educação (USP) e pós doc em Literatura (UFSCar). Contador de histórias e pesquisador de sua cultura e da cultura indígena brasileira em geral.
} 
os jeitos, pra todos os gostos e ocasiões. A literatura de cordel, característica no nordeste brasileiro, bastante estudada na academia, é um rico exemplo da capacidade criativa do nosso povo, associado às várias formas de repentistas da região.

Os contos africanos têm ganhado mais espaço ${ }^{111}$ em nossa literatura, apresentando preciosidades, conhecimentos de culturas distintas com peculiaridades e ensinamentos das mais variadas formas e temas. Coincidências e novidades que se misturam e se transformam vão aparecendo na rede de histórias que a humanidade vai tecendo. Mas, ainda são pouco conhecidos, se comparados com a importância e influência em nossa cultura. É uma área que carece de pesquisa. Há pouco material desse rico e grande continente, que não pode ser tratado como uma realidade apenas, pois são muitos países, com várias etnias diferentes, numa riqueza cultural e histórica que a caracterizam como realidades múltiplas.

Escolher não é tão simples, diante de um repertório tão extenso e complexo, quanto mais o contador tiver oportunidade de conhecer, maior sua perspectiva de uma escolha competente.

A seguir, apresento alguns aspectos da literatura autoral infantil e juvenil contemporânea, oferecida pelo mercado editorial brasileiro para orientação de leituras e escolhas de histórias autorais para serem contadas.

\subsubsection{Contos autorais: alguns critérios}

Ao optar pelo conto autoral, o contador de histórias encontra caminhos diferentes e, às vezes, divergentes a serem seguidos. Qualquer posição tomada será tão mais válida quanto mais forem conhecidas as intenções e objetivos da atividade, pelo contador. É bom insistir que não se trata de escolha certa ou errada, e, sim, diferente, para atender a desígnios diversos. Considero a importância e a responsabilidade de um contador de histórias, uma vez que é uma atividade com

\footnotetext{
${ }^{111}$ As conquistas dos movimentos contra o preconceito racial, no Brasil começam a trazer produções da cultura africana e, ao mesmo tempo, valorizar traços específicos da cultura negra. A existência recente da Lei: 10.639/2003 que torna obrigatório o ensino da história e cultura africanas e afrobrasileiras, nas escolas de ensino básico no Brasil, já em uso, ainda se manifesta de forma muito frágil e incompleta.
} 
imenso potencial formador. Por muito tempo, as histórias serviram de orientação para diversos tipos de educação, em diversos locais e épocas distintas, e, ainda hoje, continuam a desempenhar essa função, ainda que de diferentes formas.

Embora toda a literatura possa, e mereça uma narração ${ }^{112}$, abordaremos aspectos da literatura infantil e juvenil, em razão dessa ser mais utilizada pelos contadores presentes nas escolas de ensino regular, alvo mais próximo de minha atenção e experiência.

Porém, isso não quer dizer que a literatura adulta não mereça atenção. Apenas não se pode querer tudo, em um só trabalho. Assim, me contento com algumas escolhas pessoais em meu repertório, pois, a plateia adulta é sempre sedenta de oportunidades, fazendo com que os pedidos sempre apareçam. Graças a essas experiências, tenho aprendido muito sobre locais mais e menos adequados para as narrações de histórias, quando fora das escolas, a exemplos de bares noturnos ${ }^{113}$, passeios turísticos ${ }^{114}$ e outros.

No início de minha experiência (frequentando o grupo Gwaya), certa vez ocorreu que, ao apresentar uma história de Sílvia Ortoff, "Sou Miloquinha, a duende", duas colegas, ao mesmo tempo, se surpreenderam por terem dispensado este mesmo livro, achando que aquele tipo de narrativa não poderia ser narrado oralmente. O motivo é que a referida história possuía uma estrutura nada convencional, que do meu ponto de vista, exige do narrador oral uma condução diferente, para garantir o entendimento em sua continuidade. A impressão que tenho, pelos feedbacks recebidos, é de que o entendimento da narração foi conseguido com o auxílio da gestualidade e de outros recursos. A estrutura contemporânea dessa história pode deixar o contador perdido, por não possuir, nem exigir, uma ordem sequencial em seus argumentos.

Nas últimas décadas, a literatura infantil e juvenil brasileira tem crescido muito em volume e qualidade, tendo ganhado lugar de destaque junto à literatura mundial. Os livros têm composições que relacionam texto, ilustração, projeto gráfico e formato, numa criatividade sem fim. As feiras de livros mostram essa maravilhosa

\footnotetext{
${ }^{112}$ Hoje já existe um comércio de "livros lidos", são versões orais em CD de obras clássicas da literatura, tanto infantis, como também juvenis e adultos. Este mercado considera, também, o acesso de um público especial, portador de deficiências visuais e outras deficiências.

${ }_{113} \mathrm{Já}$ apresentei histórias em bares com música ao vivo (local de conversa e barulho), em locais diferentes, como: Pirenópolis, Goiânia e Brasília, sendo bem aceita e conquistando o respeito e admiração dos ouvintes, que me procuravam para conversar após a apresentação.

${ }^{114}$ Várias apresentações na Barca Brasília e em circuitos de hotéis fazenda, também contribuíram com minhas experiências
} 
diversidade. Mas a verdade é que são $\operatorname{caros}^{115}$, para os salários minguados dos professores e para as famílias de baixa renda que costumam frequentar a escola pública, realidade em que trabalho, defendo e luto por melhorias. Aqueles livros com melhores ilustrações e projetos gráficos são quase inacessíveis, sendo este, mais um motivo para se decidir por um livro bem escolhido.

Escolher implicará, sempre, em descartar uns, para que outros se tornem mais conhecidos e, diante de um mundo cujo consumo é um dos maiores valores, observo o cuidado em orientar leitores, e não, listas de compras, ou concorrência das editoras.

\begin{abstract}
A literatura, por fazer uso estético da palavra, experimenta o que ainda não foi dito, inventa algo novo, propõe protótipos, enquanto o texto da cultura de massa vem carregado de estereótipos, trazendo apenas redundância e repetição do já existente, consolidação do "status quo" (MACHADO, 2004a., p. 88)
\end{abstract}

Por isso, a literatura é tão apaixonante, por sua capacidade de suscitar emoções. O contador de histórias é um orientador de leituras, sobretudo, das histórias autorais, porque com seu encantamento ele acaba aproximando o ouvinte da obra escrita ${ }^{116}$. É complexo, se pensarmos que os gostos e as razões das escolhas podem ser as mais diversas e, uma vez que as experiências, anseios e maneiras de ver e sentir o mundo são individuais, os desejos também seguem este caminho. Haverá sempre o perigo de não agradar a todos, mas se houver o cuidado de apresentar obras de qualidade, mesmo que o estilo, ou o tema, não agrade alguns, haverá o reconhecimento do cuidado na indicação do repertório eleito. Sobre a qualidade da obra e algumas características específicas, que podem orientar as escolhas, serão apresentadas, no final desse item, com algumas indicações de critérios a serem observados, elaboradas e adotadas pela Fundação Biblioteca Nacional.

Do meu ponto de vista, o contador de histórias que escolhe seu repertório na literatura autoral, se assume, também, como um divulgador da obra literária, portanto, responsável por descobrir o que o autor quis dizer com sua obra. Há

\footnotetext{
115 Essa questão gera entendimentos diversos, mostrando sua complexidade. Entendo que é justamente a falta de valorização do livro que o mantém caro, pois se a tiragem fosse maior, poderia baratear o custo do produto.

${ }_{116}$ Hoje existem vários estudos que comprovam esta aproximação, como: Machado e Rocha (2011); Coelho (1999); Rigolet (2009); Afonso Romano (2011); Illan Brenman (2012) e muitos outros.
} 
determinados autores e determinados contextos que precisam ser respeitados e explicitados (às vezes até explicados), como exemplo, podemos citar contos de Guimarães Rosa. A peculiaridade de seu estilo se perderia, se fosse recontado livremente com as palavras do contador, pois uma das maiores riquezas de sua obra é justamente a reinvenção de palavras, que fazem parte de seu contexto cultural e seu fazer artístico.

Em arte não tem sentido ficar preso a limites: a princípio, tudo pode! Entretanto, há que se informar os créditos a quem de direito. Nesse sentido, o contador cita a fonte e o que foi feito, em caso de adaptação, versão ou outro tipo de alteração na obra autoral original. $O$ endereço completo de uma obra é seu nome (título), autor, ilustrador (se houver) e editora. Se a obra vai ser apresentada assim, que sejam respeitadas as palavras que o autor escolheu. Não se trata de um simples decorar as palavras de fora para dentro, há uma necessidade de mastigálas, sentir seu sabor e textura, entender sua mistura e cada escolha do autor. Assumir para si a história, incorporando as palavras em sua fala natural de contador, que admira as escolhas dos vocábulos realizadas pelo autor.

Isto não quer dizer que não se possa recontar uma obra literária com suas próprias palavras, é claro que pode! Dizer o que foi feito, para que o ouvinte possa ir construindo sua capacidade de observação, conhecendo quem fez o que, faz parte de uma formação crítica. $O$ que defendo é que sejamos claros e éticos. Esclarecer ao seu público qual a fonte daquela história é uma questão de lealdade e ética, consigo e com o ouvinte.

Ser crítico é ter opiniões a respeito das coisas do mundo, é discutir, analisar, palpitar, achar isso ou aquilo, não importa. Ter opinião é participar do mundo, é ter conhecimento das coisas para comparar, apreciar, escolher, rejeitar. Um sujeito crítico não aceita passivamente os produtos de consumo que a mídia lhe impõe, desconfia e pesquisa características específicas, capazes de orientar suas opções, com consciência.

É diferente de censura, porque esta é externa, de fora para dentro. A censura é o julgamento de alguém com base em valores específicos, sempre pela via negativa. Quem não tem capacidade crítica para realizar suas próprias escolhas, acaba deixando que outros o façam. Essa forma de alienação pode ser observada na submissão e aceitação passiva da sociedade, nas respostas prontas organizadas pela sociedade de consumo. 
Por outro lado, a necessidade de se cativar um público leitor, cada vez mais jovem, e manter essa atração, no mundo da leitura, não é tarefa fácil, num mundo tão repleto de imagens e movimentos. Talvez por isso, o adulto sinta tanta necessidade de escolher para a criança, fazer uma pré-seleção para que lhe cheguem coisas boas, que não a faça perder tempo. Segundo Zaíra Turchi ${ }^{117}$, "a contribuição da crítica da literatura infantil e juvenil está em distinguir com clareza os protótipos dos estereótipos" (2002., p. 30).

Mas, como a criança poderá construir seu espírito crítico se as coisas já chegarem para elas escolhidas? Não é melhor que ela mesma decida o que é bom ou ruim? Ou que tenha liberdade para decidir o que mais Ihe interessa?

Os professores precisam de alguma orientação, seja pela falta de oportunidade, falta de formação, ou desejo de aprofundar-se no conhecimento da grande diversidade de obras literárias existentes, hoje, no Brasil.

A crítica que se pretende construir é no sentido da orientação na formação de leitores, capazes de construírem sua autonomia de leitores. Essa orientação pode ter algumas considerações que não comprometem a autonomia e o gosto individual e, ao mesmo tempo, garantam uma qualidade mínima da obra, incentivando cada vez mais leitores.

As orientações, a seguir, foram utilizadas pela equipe do CEDOP (Centro de Documentação e Pesquisa), para as seleções avaliadas pela Fundação Nacional do Livro Infantil e Juvenil - FNLIJ ${ }^{118}$.

É importante frisar que se trata de orientações, e não, regras fixas, com base na teoria da leitura difundida hoje, em que o leitor tem parte ativa no processo de interpretação da obra, interagindo com ela. A especificidade da visão de cada leitor é construída com a amplitude do campo de sentidos, devendo ser respeitada e, ao mesmo tempo, gerando divergências de pensamento, ou seja, as escolhas poderão não ser consensuais.

há obras inesquecíveis e obras que não deixam um traço na memória do leitor, a não ser o enfado. Portanto, não se pode perder tempo na indicação de obras razoáveis quando há outras desafiando o gosto e a inteligência do leitor. (...) A leitura crítica, que sem academicismo todos poderíamos

\footnotetext{
${ }^{117}$ Maria Zaíra Turchi, professora titular da Faculdade de Letras da UFG, atualmente presidente da Fundação de Amparo à Pesquisa do Estado de Goiás (FAPEG), possui um rico e extenso currículo na área de teoria e crítica literária, com livros indicados e premiados nacionalmente.

${ }_{118}$ Orientações formuladas na década de 1990, encontradas facilmente nas redes de pesquisa da internet, amplamente divulgadas pelo Proler em sua campanha.
} 
exercer, subscreve as seleções e recomendações. Quando alguém busca um livro de literatura, busca-o para alcançar o prazer, não o prazer morno e ordinário, mas algo que dê arrepios, leve a percepção nova das coisas, amplie a imaginação e que lhe dê o sentimento do mundo e do homem. Há, pois que se ler com os dois olhos. Bem abertos (YUNES, 2012, p. 41/42).

Entretanto, sabemos que o que faz alguns se arrepiarem, pode fazer outros rirem, ou ainda, provocar enfado e outras reações. Mas, a qualidade literária, quando é boa, captura o leitor de tal maneira que não deixa dúvidas nem pede explicações.

Como primeira recomendação, são indicados livros que proporcionem o gosto pela leitura, conjuguem a qualidade da edição gráfica com a qualidade literária, e ainda, valorizem o livro como tal, considerando as especificidades dessa linguagem, articulando texto e imagem, quando houver.

A qualidade literária se apresenta no uso da linguagem com sua força e expressão, identificando, às vezes, regionalismos em seus contextos. A atenção ao tratamento do tema avalia sua originalidade, onde os personagens evoluem, no decorrer da obra, apresentando, também, as sequências temporais que mantenham o leitor cativo e sejam surpreendentes ao tratar de temas conhecidos. Obras com linguagem artificial, ou com excesso de diminutivos, e obras com didatismo e moralizantes, são evitadas pelos professores, que acreditam em uma formação para a autonomia e a criticidade.

Se for uma obra de origem estrangeira, verificar se a tradução é direta da obra original, pois sabe-se que problemas de tradução são sempre complicados, pelos riscos de traição, por pertencerem a universos culturais diferentes. O mesmo com as adaptações, em que se observam as informações de quem adaptou e com quais considerações. Dar atenção às obras clássicas, de outras culturas, sobretudo aquelas que, nem sempre, são facilitadas.

Outra característica que pode orientar leitores e contadores é a qualidade gráfica do produto final, o livro. Evitar quando a diagramação for confusa, com superposição de texto e imagem, atrapalhando a identificação das letras, ou quando a página é tão fina, que a transparência embaraça a imagem, fazendo sombra no outro lado da página. Observar as capas atrativas, mas que tenham relações com o conteúdo do livro e o formato que auxilie a leitura. As letras devem ter um desenho claro e ter um bom tamanho: quanto menor a criança (iniciante na leitura), maior o tamanho da letra, mas sem exagero. Analisar a presença de informações técnicas 
como: numeração nas páginas, indicações de bibliografia, informações sobre os autores e ilustradores. Estas orientações, que acompanharam a equipe do Proler, deixaram influências em muitos grupos e contadores que existem hoje.

Geralmente, as editoras lançam catálogos de suas obras, em que os interessados podem conhecer e se orientar para leituras e escolhas. No entanto, os catálogos não informam a obra inteira, apenas fragmentos, só funcionando para os leitores que acompanham a produção na área. Hoje, a maioria das salas de aula tem uma biblioteca, embora, nem sempre, sejam utilizadas ou atualizadas. São conquistadas com doações de livros, pelos próprios alunos e comunidade, ou por meio de projetos ${ }^{119}$ de naturezas variadas, que incentivam a leitura, fornecendo condições materiais para as escolas.

O mundo das histórias propicia um trabalho prazeroso, pois as histórias podem auxiliar a manter um clima gostoso, de aconchego, mesmo em ambiente escolar. Mas, em contrapartida, o professor tem de ser o primeiro a gostar de ler, incentivando e abrindo espaços para seus alunos a buscarem os livros, autonomamente, em sala de aula.

Ao escolher um conto autoral da literatura infantil e juvenil, o contador se aproxima do livro como um todo, incorporando suas palavras, e quando possível, aproveitando, também, as ilustrações, que fazem parte da narrativa apresentada na obra. Em minhas observações, na escola de ensino básico (onde atuei por mais de quinze anos), são impressionantes as reações de júbilo de uma criança em fase de letramento, quando esta identifica em um livro da biblioteca ou da sala de aula, uma história que foi contada com as mesmas palavras. É visível a emoção expressa nos olhos, as expressões e atitudes do jovenzinho aprendiz descobrindo as palavras e a leitura. Geralmente, eles imitam a entonação do contador, quando descobrem a palavra no processo de leitura. Esta descoberta é uma maravilha experimentada por muitos educadores atentos ${ }^{120}$ aos movimentos dos pequenos.

\footnotetext{
${ }^{119}$ As atuais políticas de gestão escolar tem encontrado, nos projetos formas interessantes de equipar a escola; ao mesmo tempo, as compras de materiais didáticos são feitas por projetos; portfólios; pontuações e estratégias locais.

${ }_{120}$ Observações neste sentido foram comentadas, mais de uma vez, pelas professoras: Cleidna Landivar, Fátima Teixeira e Telma Mota, parceiras no Gwaya e no Cepae, entre os anos de 1993 e 2002.
} 


\subsection{A preparação do conto - aproximações com o texto}

As formas que cada um elege para estudar e preparar a história são tão pessoais quanto à própria escolha do texto. Além de cada história oferecer suas especificidades, o contador tem, ainda, sua forma particular de entendê-lo, identificando os recursos orais, gestuais e rítmicos que poderá empreender, como coadjuvantes da interação entre contador e público.

Cabe ao contador conhecer os objetivos de seu intento, aprofundar 0 conhecimento na composição da narrativa, para pôr em prática o estudo realizado. O entendimento da estrutura do texto em suas diferentes formas e seus detalhes é de fundamental importância, não só para contar, mas, também, na preparação da história, para saber tirar dela os pontos que chamam atenção e ajudam a amarrar o entendimento do conto. Embora cada experiência revele suas particularidades metodológicas, um primeiro ponto comum, que observo entre os estudos dos narradores, é a necessidade de conhecer a estrutura da história.

Hoje em dia, sobretudo, nos centros urbanos, são poucas as pessoas que conseguem improvisar bem, sem nenhum tipo de preparo prévio. A prática tem revelado que a experiência de ouvir é tão importante quanto contar. Encontramos quem se arrisca a improvisar narrativas com sucesso, geralmente, em locais com muita experiência em ouvir histórias, seja em família ou profissionalmente, mas, certamente, onde a cultura oral é valorizada e presente.

Após a discussão sobre as opções de linguagem e a necessidade de conhecimento para a escolha do repertório, passo a refletir sobre formas de preparar para contá-lo. Nesta abordagem, cada opção se faz acompanhar de suas consequências, sendo papel do narrador oral identificá-las para assumi-las.

A experiência da contadora Estrella Ortiz revela a sua opção: "No trabalho dos contos literários devemos grande respeito ao escritor que criou o relato, respeito que inclui citar sua autoria antes, durante ou depois da sessão" (ORTIZ, 2004, p. 107). Isso mostra a opção da contadora na fidelidade com suas fontes. Outra solução que corrobora com essa ideia é a distribuição de programas com títulos, autores, editores e contadores.

Quando a alternativa for por uma história autoral, assumo que as palavras escolhidas pelo autor devem ser respeitadas e mantidas, pois o contador é um divulgador da obra literária e, como tal, assume suas responsabilidades. Há uma 
necessidade, em muitos casos, de estudar o autor, saber 'quem é' e 'de onde ele fala', sob pena de se afastar das reais intenções da obra daquele autor. Sobretudo, quando forem obras tradicionais, de grande representatividade.

Em um mesmo exemplo do meu repertório, nota-se outro ponto a ser refletido: o resumo. Resumir, sem cautela e conhecimento, um texto da autoria de Cora Coralina, seria como decepar uma parte do corpo, pois no resumo, os adjetivos seriam os primeiros a desaparecerem, sendo uma de suas principais características. Nomear uma porção de adjetivos para um só objeto, enquanto denúncia à dureza com que eram tratadas as mulheres e crianças de sua época, é uma das características marcantes na estética da obra dessa autora ${ }^{121}$ :

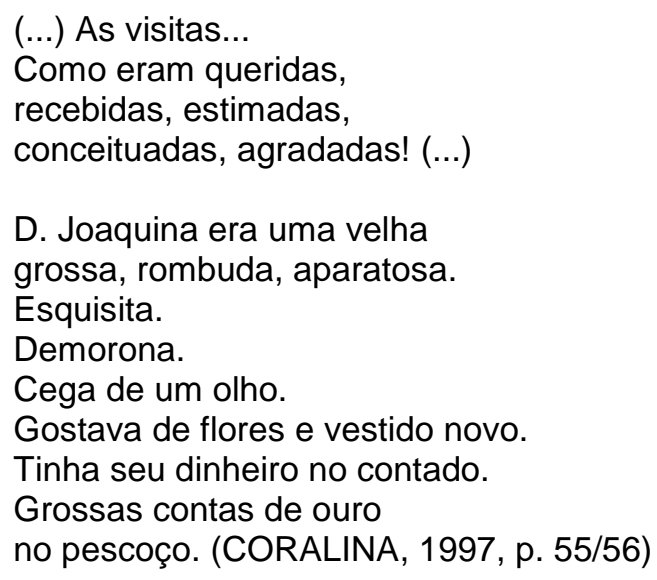

O estilo e estética literária da autora tem uma história reveladora em forma e conteúdo, que corre o risco de ficar descaracterizada, se alterada. Portanto, assumo as palavras da autora como se fossem minhas, entendendo e aceitando cada uma de suas escolhas, quando faço opção por uma obra literária em meu repertório pessoal. Não considero como um simples decorar de palavras, mas, sim, um estudo profundo para conhecer o significado de cada vocábulo que se pronuncia e o que eles significam juntos e naquela ordem, naquele contexto. Quando se fala em internalizar o texto, isto significa apropriar-se dele de tal forma que é como se já lhe pertencesse, como se a história tivesse acontecido, realmente, com o contador. É como se a admiração pela composição do texto, ou seja, por sua estrutura e tipo de escrita, o fizessem torná-lo parte do contador. Ao contar uma história literária sinto a necessidade de curtir cada palavra, como se eu as tivesse escolhido, admirando as

\footnotetext{
${ }^{121}$ Esse poema já foi exemplificado em outro trecho, na discussão do capítulo anterior, sobre o imaginário do contador de histórias, explorando a imagem do bolo.
} 
preferências do autor. Isto também não é uma regra, mas, sim, uma escolha consciente de suas consequências, coerente com meu ofício de arte educadora.

Fabiano Moraes (2012) também reconhece a importância de esclarecer ao ouvinte a autoria e o tipo de adaptação, se houve alguma modificação em relação ao texto original. Há autores que não querem adaptação livre de seus contos, ele diz. E nós concordamos: é preciso respeitar!

Com as narrativas populares, por não terem autor conhecido, pertencendo à oralidade, a liberdade de recontá-las é maior, cada um conta do seu jeito, pois somos todos autores. Quem conta um conto aumenta um ponto! Esse ditado popular ilustra o que acontece com as histórias, revela como as narrativas vão se transformando, ao longo dos tempos, comprovando a dinamicidade da cultura. Hoje, temos muitas versões de contos tradicionalmente conhecidos que são alteradas propositadamente. Elas nos mostram que as histórias apresentam variações, em cada versão de quem conta. Muitas vezes, apontam traços culturais de determinadas épocas, lugares e povos, revelando suas peculiaridades e curiosidades.

Segundo Girardello (2014), a narração e a leitura de histórias podem ter status artísticos, embora atuem de formas diferentes, dependendo da linguagem utilizada. A narração, sem apoio do livro, pode exigir maior capacidade de improviso com as palavras, aproximando contador e ouvinte, quando este se preocupa com a linguagem adequada a seu público.

As crianças menores ou aqueles que têm pouco contato com leituras (palavra escrita), por exemplo, têm na narração oral maiores possibilidades expressivas e interação lúdica com o contador.

\footnotetext{
A história contada tem clara dimensão de jogo (...), durante a brincadeira, porém, o presente do sentimento lúdico predomina. A engenhosidade, a risada, os desafios físicos e cognitivos e a alegria de sua superação a fruição da rede das relações políticas e afetivas com os parceiros de jogo (GIRARDELLO, 2014, p. 5).
}

Os parceiros, neste caso, são: ouvinte e contadores. E a brincadeira acontece durante o desenvolver da história, no envolvimento de ouvintes e contador na significação das palavras; na elaboração de imagens e vivências de emoções, enfim, na presença do contador. A ludicidade está na liberdade dessa construção. 
Contudo, a base da formação do contador de histórias está na compreensão da forma narrativa, apontada por diversos autores: Machado (2004a.); Matos (2006); Busatto (2012); Girardello (2014).

Como diz Regina Machado: “É bom, é importante inventar e recriar histórias desde que o trabalho seja acompanhado de um conceito claro do que é uma narrativa, qual o seu propósito, função e estrutura" (2004a., , p. 30).

De acordo com Girardello (2014), a narrativa é uma compreensão que chega cedo à vida da criança: no ventre, no colo, no berço, cantigas, acalantos, fala dos adultos. A criança que tiver contato com a linguagem terá contato com a narrativa. "Precisamos da forma narrativa para entender as ações alheias, porque entendemos as nossas próprias vidas enquanto narrativas que se desenrolam gradualmente"122 (2014, p. 2).

Gilka Girardello (1998), em sua Tese de Doutorado, entende narrativa como "uma instância intermediária entre o imaginário e a cultura" (p. 44). Compreender a narrativa como mediação entre o imaginário e a cultura exige do contador uma percepção ampliada e aprofundada de si mesmo e da cultura em que a história está envolvida. A preparação da história exige conhecimentos que vão além das palavras escritas no conto, demanda informações sobre o contexto, sobre o não dito, abrindo o campo do imaginário.

Para esse entendimento, a autora apresenta uma "plataforma de observação quanto às relações entre narrativa, imaginação e cultura" (GIRARDELLO, 1998, p. 89), o que leva à compreensão de que o encontro por meio da palavra e da troca narrativa é, a um só tempo, construção subjetiva e produção cultural. "Embora a narrativa seja uma atividade cultural universal, os tipos de histórias e conteúdos que se costuma contar variam de uma cultura para outra, dentro de uma mesma sociedade" (ibidem, p. 9). Segundo a autora, as histórias e fábulas apresentam um encadeamento de eventos, enquanto o discurso está na forma da expressão narrativa, com seus componentes básicos. A compreensão da narrativa se mostra, então, como componente básico na presença do conto.

Ao iniciar a preparação de um texto a ser contado, vejo nas experiências de meus alunos que escrever ou digitar tem sido a forma mais comum para o início. Essa necessidade pode ser explicada pelo pertencimento a uma sociedade letrada,

\footnotetext{
${ }^{122}$ Pensamento desenvolvido por Mc Intyre (1981) traduzido e refletido por Giardello em seu artigo.
} 
isso é fato. Depois, é importante que o contador se liberte do texto, sinta as palavras fluírem. Escrever é necessário para ajudar a organizar as ideias, para identificar a função e a estrutura da narrativa e para registrar o conto, caso este não tenha registro conhecido. Quando se faz parte de um mundo letrado é natural que precisemos dele, e confiar apenas na memória pode representar riscos. É diferente, para aqueles cuja experiência de ouvir e contar histórias é comum e cotidiana, seja em casa ou em sua comunidade. Para esses contadores, a narração de histórias já faz parte deles, vão sendo incorporadas na experiência cotidiana, estão dentro deles, pertencem a eles.

Ainda que cada um encontre sua forma particular de estudar e preparar uma história, experiências sistematizadas podem orientar e dar ideias ao oral aprendiz, em suas buscas. Assim, compartilho minha experiência pessoal na preparação do texto, discutindo, refletindo, dialogando e complementando com os pontos coincidentes nos estudos de outros contadores como: Regina Machado (2004a.), Gislayne Matos e Inno Sorsy (2009) e Vânia Dohme (2000), Cleo Busatto (2006), Celso Sisto (2012a) e tantos outros contadores, colegas que disponibilizam suas experiências.

\subsubsection{Estudando os textos}

Ao pensar ou apoiar formas de abordagens para os estudos das histórias escolhidas, recupero a concepção de ensino/aprendizagem que orienta minha prática, explicitada no primeiro capítulo, recorrendo às concepções sóciointeracionista, desenvolvidas por Vygotsky, Leontiev, Lúria e Wallon ${ }^{123}$, pautadas, também, nos educadores Paulo Freire, Ruben Alves, Carlos Brandão e outros, apontando que o primeiro ponto a ser considerado é o respeito à condição do outro e os modos de cada um aprender e ensinar. Portanto, não proponho, nem acredito, em um único modelo de preparação de um texto.

Assinalo isto vinculando os exercícios do contador em construção, ao princípio da ludicidade explicitado no primeiro capítulo, que permeia minha prática,

\footnotetext{
${ }^{123}$ Os três primeiros autores são russos e o último francês, psicólogos da educação, autores de teorias de ensino/aprendizagem de concepção sócio-interacionistas. São autores que serviram de base para minha monografia de especialização defendida na UFG, sob a orientação da $\operatorname{Prof}^{\mathrm{a}} \operatorname{Dr}^{\mathrm{a}}$ Ivone Garcia.
} 
embora, neste estudo, a descrição das experiências tenha o foco na experiência do contador, aceitando os exemplos de jogos e vivências lúdicas implícitos nos resultados aqui expostos. Deste modo, não há, neste estudo, exemplos, ou listas de jogos para o desenvolvimento de determinadas habilidades, e sim, qual habilidade precisa ser desenvolvida e para que.

$\mathrm{Na}$ intenção de contribuir com os contadores de histórias, apresento alguns exemplos de leituras do texto que se pretende estudar, explorando formas diferentes que podem auxiliar o contador em sua compreensão e, consequentemente, na elaboração de sua performance narrativa.

Para se contar uma história, se faz necessário conhecer profundamente o texto, a ponto de dominá-lo como se ele fosse seu, mais do que, simplesmente, aprender as palavras que o compõe, em sua linearidade e entendimento. As experiências das oficinas para contadores de histórias me mostraram que ler, de várias maneiras diferentes, com objetivos, dinâmicas e exercícios variados, amplia a compreensão da leitura e, consequentemente, influencia positivamente a narração. Ajuda a construir sentidos que, muitas vezes, não estão explícitos, e sim, localizados nas entrelinhas da escrita, ou seja, significados que são indiretos, mas que são fundamentais na compreensão da trama para o emprego de recursos na narração.

Faz parte de minha criação artística variar as formas de estudo de um conto, assim como variar gêneros e estilos de textos. Mas, no fim de cada estudo, os resultados são muito semelhantes, e cada contador sente quando um texto já está maduro para ir a público. De qualquer forma exige prática.

Revisando meus cadernos de planejamento, diários de campo (comentários e relatórios de cursos e oficinas) e os estudos do mestrado, faço a opção por continuar com as quatro leituras já iniciadas, mencionadas abaixo, por terem sido a direção dos jogos e exercícios trabalhados em sala de aula, se constituindo em experiência vivida, que passa a ser analisada nos itens: a) estrutura; b) leitura vertical; c) partes; d) sequência; formas de estudo e aproximação com o texto, das experiências minhas e de outros contadores. Entretanto, ao aprofundar-me nesta investigação, vejo que é possível uma conversa entre pontos coincidentes nas experiências de outros contadores, muitas vezes, fazendo deste, um texto construído há muitas mãos. Se considerado por alguns como uma colcha de retalhos, assumo que sejam bem coloridos e bem costurados, convidando ao aquecimento, sustentado pelo 
envolvimento caloroso da palavra narrativa, como fonte de calor humano, nos remetendo às ancestrais rodas de fogo.

Ao abrir diálogos com os autores e com as minhas experiências, procuro deixar acesas as possibilidades para cada contador saber criar sua própria forma de estudo, sabendo aproveitar as sugestões relatadas.

\section{a. Estrutura}

O primeiro encontro com o texto, foi no momento da escolha, período de paixão e encantamento. Essa primeira memória afetiva já é responsável por grande parte do que será guardado e definido. $O$ texto se tornou imediatamente conhecido em sua estrutura básica, pois é facilmente lembrado em sua essência.

Considero ser o esqueleto do texto aquilo que dá sustentação à história. É preciso conhecer e dominar, para que o contador fique livre para improvisar, com maior liberdade e possibilidade de interação com o público. Nos primeiros contatos com o texto, já é possível identificar suas principais características e identificações como gênero, estilo ou tipo.

São muitos aspectos que podem indicar a estrutura de um texto escrito: em prosa ou em verso; um conto tradicional; uma história cumulativa; uma narrativa circular; um conto literário moderno; uma fábula; ou se é próximo de algum outro tipo. Quando a estrutura é conhecida, improvisar as palavras fica mais fácil, em minha experiência. Portanto, um dos estudos associados ao contador são os estilos de histórias que possuem estruturas próprias, correspondentes as suas características, alguns, exemplificados no estudo do repertório.

Exemplificando algumas estruturas de histórias: as cumulativas são aquelas que vão acumulando as ações, e a cada momento se repetem. Como exemplo conhecido de minha região, cito a música: "A árvore da montanha", ou a história "A Formiguinha e a Neve ${ }^{124 "}$. Na pesquisa de Pirenópolis, "Os Contos do Arco da Véia", no 'anexo 2', temos como exemplo de história cumulativa, "A História da Carochinha", contada por Seu Ico.

\footnotetext{
${ }^{124}$ Conto popular muito conhecido, gravado na coleção Disquinho, em que os personagens vão se acumulando na narrativa e a última frase, praticamente reconta toda a história. Esta coleção foi reeditada em CD, com o livro acompanhando, pela editora Moderna em 2000.
} 
A história circular é aquela que, ao final, volta-se ao mesmo ponto de partida, geralmente repetindo um mesmo verso, durante a narrativa. Como exemplo, bastante conhecido entre os contadores atuais: "Menina Bonita do Laço de Fita" de Ana Maria Machado ${ }^{125}$. Outro exemplo encontrado nos "Contos do Arco da Véia" é "A Moça Trouxa", contada por Dona Benta, e "Caçando uma Esposa", contada por Safia $^{126}$.

O conto literário moderno se caracteriza por uma estrutura não linear, que admite, inclusive, troca das partes sem perder o fio da narrativa, nem o significado da história. Sílvia Ortoff tem boas histórias assim. Já tive oportunidade de contar: "Sou Miloquinha a Duende", e, algumas vezes, troquei partes de lugar, distraidamente, sem alterar o sentido da história.

Durante as oficinas que ministrei, pude observar que os alunos com maior facilidade para compreender a estrutura da história conseguiam chegar, ao fim da narração, sem se perder na ordem dos acontecimentos. Se a estrutura for alterada, pode estragar a compreensão da história, apresentando, por exemplo, o resultado antes da apresentação do problema.

Observo que a maioria dos autores pensa nessa mesma direção: "Cada história pede ao contador uma maneira de contar" (SISTO, 2004, p. 85). Para Fox e Girardello "Não existe um único jeito de ser um bom contador de histórias. Cada um de nós tem seu estilo pessoal, em termos das histórias que escolhem e da maneira de contá-las" (2004, p. 185). O retorno possível se dá em orientação do que funciona ou não funciona em cada caso isolado, sendo que as generalizações vão, certamente, encontrar exceções, ou seja, não funcionam. Entretanto, percebo o consenso entre os contadores, sobretudo de que uma história deve, sim, ser bem preparada para ser contada.

Reduzir a estrutura do conto a um número mínimo de estágios, encontrando as ações que modificam o conto, é a forma que tem mostrado mais eficiência, nos cursos e em minhas preparações pessoais. Alguns anotam em papeis ou cartões e há quem prefira formar imagens mentais (cenas congeladas). Cada um encontra sua forma de estudo para identificação da estrutura do conto escolhido.

\footnotetext{
${ }^{125}$ História que ficou muito conhecida pela performance de Celso Sisto, nas oficinas do Proler e é recontada por todos os cantos do Brasil, fato comentado nos eventos de contadores de histórias que tenho participado.

${ }^{126}$ As histórias citadas ao longo da redação estão no anexo 2.
} 
Minha experiência revela que conhecer os vários tipos de histórias ajuda a identificar, mais rapidamente, sua estrutura, e esta, sustenta o que vem a seguir, que são os detalhes que preencherão seu esqueleto.

Antes de passar à próxima leitura, faço uma breve abordagem sobre outras propostas de estudos, que consideram a "estrutura" da história como ponto de partida de seus estudos.

Margarida Baird, premiada como atriz, no papel de contadora de histórias de Nashudin, indica a estrutura do texto como base para seu aprendizado. Descobrindo o tesouro dos contos Sufis, aprendeu a dividir textos em oito partes, como se fossem "templos octogonais, e cada fatia, uma parte estrutural do conjunto a ser desvendado, e de cada parte tirar a frase principal que vai resultar no esqueleto do conto, aquele resumo essencial que se guarda na memória" (BAIRD, 2004, p. 73). Essa mesma divisão é encontrada em vários outros autores, com suas particularidades.

Regina Machado (2004a.) divide o conto em oito partes ${ }^{127}$ (método bastante conhecido entre os contadores ${ }^{128}$ ), sendo que a primeira consiste em identificar 0 motor da história, geralmente, a tarefa a ser perseguida, que acompanha todo 0 conto. A seguir, as outras partes seriam os acontecimentos e ligações entre eles. Com isso, a autora considera ser possível ter aprendido a estrutura do conto, que precisa ser preenchida por cores, formas, texturas e sensações. Essa divisão, em oito partes, serve para elaboração de um roteiro da história, exercitando e auxiliando, também, na memorização do conto.

Gislayne Matos e Inno Sorsy, em seu livro: "O ofício do contador de histórias", também ensinam uma divisão do texto em oito partes: 1 - busca; 2 - coleta das histórias; 3 - a escrita e a dúvida; 4 - o retorno; 5 - a solução; 6 - bebida; 7 memória; 8 - conclusão. Em cada um dessas partes, as autoras propõem um entendimento por meio de uma metáfora da constituição do corpo humano: esqueleto (a estrutura do conto); músculo (aquilo que preenche a estrutura e permite significações múltiplas); sangue e respiração (são o ritmo de cada parte e a cadência entre essas); coração (é a intenção do contador, em cada detalhe a ser

\footnotetext{
${ }^{127}$ Divisão que Regina Machado diz ter aprendido com Nícia Grillo, que tive o prazer de conhecer e participar de sua oficina oferecida pela Boca do Céu, em 2012.

${ }_{128}$ Fato que tenho observado com frequência nos cursos que tenho frequentado, com certo incômodo, quando o entendimento é aceito pelos alunos como modelo a ser seguido, muitas vezes, distorcendo o que está sendo dito pelo orientador da oficina.
} 
narrado). Quando iniciei o preparo, por exemplo, da história Dona Carochinha (anexo 2 - Arco da Véia), usei a metáfora sugerida pelas autoras, assim identificados: esqueleto - história cumulativa, dividida em 9 passagens; músculo - o que acontece em cada parte (Em luto a Dom Rato que caiu na panela de fritar bolinhos, Dona Carochinha não para de chorar, a porta resolveu abrir e fechar, a porteira bate-bate, o passarinho perdeu suas penas, a árvore perdeu suas folhas, 0 boi tirou o chifre, o ribeirão secou e a menina quebrou o pote); sangue e respiração - esta história é construída junto com o público, que vai aprendendo e falando junto, como em uma lenga-lenga; coração - são as estratégias que o contador vai usando para atrair o público, utilizando oralidade, gestualidade e ritmo da linguagem corporal do contador.

Vânia Dohme, contadora e professora da arte de contar, assinala que "para estudar uma história é preciso, em primeiro lugar, divertir-se com ela, captar a mensagem que nela está implícita e, em seguida, após algumas leituras, identificar os seus elementos essenciais" (2000, p. 27). Concordo com a posição da autora e também considero que a ficha modelo, apresentada em seu livro, para orientação do estudo da história, pode enriquecer os estudos de muitos textos. Entretanto, discordo de seu uso enquanto modelo, ou enquanto obrigação para o estudo de qualquer texto. Minha experiência me leva a considerar que uma única forma de estudo não atende a todos os tipos de textos e nem a todos os tipos de contadores.

\section{b. Leitura vertical}

Considero que a leitura vertical é a busca, o entendimento minucioso do texto, conhecido como subtexto, ou entrelinhas. Um entendimento que vai além do que está escrito, permitindo a constituição das características dos personagens e paisagens suscitados pelo texto, em detalhes; uma construção psicológica ${ }^{129}$ e sociológica de personagens e ações do texto.

Consiste em reler cada linha, tentando entender seu contexto, ampliando as formas de pensar e compreender os significados das palavras. Descrever cada personagem, separadamente, construindo suas características: idade, fala, cor, tamanho, tipo físico, forma de andar, pose, roupa, o que come, do que vive, de que

\footnotetext{
${ }^{129}$ Esta construção de cada detalhe do personagem, pode ser relacionada às ações físicas para a construção de personagens proposta por Stanislavsky.
} 
gosta, parentes, casa, traços psicológicos, relações com os outros personagens, etc. Descrever os lugares onde se passa a narrativa, com cenários que revelam cores, tamanhos, formas, cheiros, sensações, texturas e movimentos. Quando o contador formula as imagens daquilo que está narrando, ele permite que o ouvinte também o faça.

Nessa leitura começamos a pensar, também, nos recursos da linguagem corporal a serem empregados, que serão explorados no próximo capítulo.

As informações propiciadas pela leitura vertical oferecem informações suficientes para o preenchimento da estrutura identificada, anteriormente. Quanto maior o vocabulário do contador e sua capacidade de formar imagens, mais facilidade ele terá para descrever paisagens, sensações e características de personagens, enriquecendo a narrativa. Quanto mais diversificada for a descrição dos detalhes, no estudo da história, mais rica será sua narração.

Considero importante oferecer a narrativa como protagonista e estrela da apresentação. O contador é apenas um veículo que chama a atenção do ouvinte para as palavras da história. A admiração é dirigida às palavras, desviando-se do contador em sua atuação, por isso, a necessidade de ampliação do repertório de palavras. O contador de histórias é um colecionador de palavras e direciona sua atenção ao texto, levando os ouvintes nessa viajem.

Estímulos para mediar leituras oferecidas por Elias José, como: "ler o mundo, ler um texto, anotar sonhos interessantes, olhar bem um quadro de pintura que nos emocionou, ouvir uma música envolvente, conversar com quem tem histórias para contar, recontar as próprias histórias que vivemos em família ou no convívio social" (JOSÉ, 2012, p. 13), oferecem oportunidades para abertura do contador.

FABIANO MORAES (2012) propõem em seus cursos, em Vitória - ES, uma metodologia teórico-prática, lúdica em sua didática: brincar de refazer, de reinventar, de representar e de reencantar, tanto o mundo quanto a própria vida, são as aproximações que abrem o diálogo com minha experiência. Sua proposta se apoia em três atributos do narrador: onisciência (saber); onipotência (poder); onipresença (estar), sendo cada contação um "evento único e original" (2012, p. 17). Essa proposta, do meu ponto de vista, se identifica com a "presença do narrador", apontada por Girardello, em sua Tese de Doutorado, na "tripla competência", descrita por Lyotard, aqui apresentadas no início do terceiro capítulo. 
A metáfora criada por Shedlock, ao associar a narração com um bordado pronto para ser admirado, se esquecendo de atentar para qualquer esforço de onde está o início ou as emendas, é um exemplo de competência do contador de histórias. Para a autora é "a arte de esconder a arte (...) A aparente falta de esforço do artista tem um efeito reconfortante sobre quem ouve" (SHELDLOK, 2004, p. 23). Mas, para que o esforço não apareça, o contador tem um grande trabalho para conhecer e dominar o entendimento do texto, percebendo seus recursos narrativos. Essa forma de leitura se identifica com os preenchimentos do bordado.

\section{c. Partes $\rightarrow$}

Dividir a história e pensar cada parte, com suas características, ritmo e entonação, resulta em maior compreensão e interação com o texto. Essas partes são oferecidas, ou definidas pelo próprio texto, considerando seu estilo, tamanho e dinâmica.

A divisão depende da estrutura, já identificada nas primeiras leituras e consiste em: início, meio e fim, em uma estrutura tradicional, sendo o meio subdividido em outras partes; número indeterminado de repetições, nas histórias cumulativas, dependendo do número ações e personagens; pontos de passagens nas narrativas circulares; ações que preparam o clímax nos contos tradicionais. Essa divisão é orientada pela estrutura da história, por isso, não é possível construir um modelo único. As partes variam de acordo com a estrutura e o entendimento de cada narrador oral e, ainda, depende do gênero ou tipo da história.

Em alguns textos, dar nomes a cada parte ajuda, não só na memorização do conto, como, também, na fase seguinte, que recupera a ordem dessas partes.

Cada parte, selecionada pelo contador, tem sua importância e seu ritmo, que não deixam a narrativa ficar nem lenta de dar sono e vontade de dormir, nem rápida demais que a plateia não entenda as palavras e não tenha tempo para construir as imagens. Neste ponto do estudo são investigados os alvos mais importantes da história, definindo quais deles devem chamar mais atenção, facilitando sua compreensão.

Ao identificar as partes de uma história, pensando em sua narração, o contador estabelece variações que estimulem a interação entre contador e ouvinte. Com o ritmo de cada uma das partes, se constitui a cadência do conto, que, para 
Regina Machado, "é feita das ligações entre as diferentes qualidades que se manifestam em cada parte da sequência narrativa" (MACHADO, 2004a., p. 38) Ou seja, o contador identifica os climas de cada parte do conto, por meio de suas qualidades essenciais, descobrindo a respiração da história, para respirar junto com ela. Essa respiração conjunta influencia no ritmo e a cadência da história.

Para a autora, essa característica vem de uma disposição interna do contador. Estimular essa disposição interna significa exercitar as habilidades de observação, percepção, curiosidade, formação de imagens internas, sonhar, desconsiderar certo e errado. Ou seja, ter flexibilidade. "A flexibilidade traz eficiência poética para a arte de contar histórias" (MACHADO, 2004b, p. 45) e capacidade de brincar - virar o olho. Não é só a técnica e o repertório, "aprender a recordar o que já sabia, mas não sabia que sabia" (ibidem, p. 48). Ideia que tive a felicidade de presenciar, nos depoimentos e avaliações de alunos em cursos e oficinas. Algumas anotações registradas em relatórios de oficinas para professores da rede pública merecem destaque: "pra mim o mais importante foi descobrir o que tem dentro da gente, pra contar bem uma história"; "uma viagem para meu interior, foi assim que achei meu contador"; “a professora faz a gente se sentir gente", falas das alunas ${ }^{130}$, que associo às ideias de Regina Machado, sobretudo, pelo contexto da oficina, que, em parte, já foi relatada, no primeiro capítulo.

Em cada parte da divisão do texto será pensado que tipo de elementos funcionam melhor naquela narrativa, dentre os recursos da linguagem corporal (oralidade, gestualidade e ritmo); fluência à narrativa para a compreensão da história. As dinâmicas são preparadas com os recursos da linguagem corporal, apresentados no próximo capítulo. Pensar cada parte com os recursos que lhe são pertinentes, ajuda a limpar os exageros da interpretação e criar fluidez na narração.

\section{d. Sequência $\rightarrow$}

Tendo cada parte, cada pedacinho e cada detalhe da história na cabeça, pensar na sequência da narrativa, recoloca as coisas no devido lugar. Depois de tanto mexer, para lá e para cá, a cabeça do contador acaba saindo um pouco do 'prumo'. É preciso retomar a sequência, colocar a narrativa em ordem, para suscitar

\footnotetext{
${ }^{130}$ Avaliações escritas pelos alunos da oficina de formação de professores, arte educadores de Porangatu, cidade do Estado de Goiás.
} 
no ouvinte seus significados. É outra forma de estudar o texto, em que os principais fatos são destacados para depois encadeá-los, novamente, como se fosse um sumário. Uma forma de lembrar cada parte, rapidamente, na ordem correta do texto.

A intenção é conseguir, com uma pequena sequência das partes da história, que o contador seja capaz de relembrar todo o texto, de forma rápida e segura. Elias José (2012) justifica essa necessidade apontando que o homem é um animal datado e situado, em que os acontecimentos se dão quando e onde, em um tempo linear, em um espaço delimitado. Assim, ao preparar uma história para narrar, ordena as partes, enumerando-as para que o contador não se perca. Essa organização temporal é uma exigência do narrador, mas, sobretudo, de quem ouve.

Regina Machado (2004a.) utiliza a metáfora de uma locomotiva com seus vagões, para explicar uma sequência narrativa, que se faz no entendimento ou na identificação do núcleo e da organização (ordem) dos vagões. Aí, então, o contador aprendiz daquela história passa a pesquisar e estudar o que tem em cada vagão e a ligação entre eles. Porém, o mais importante para a autora é a pergunta direcionada à história: "O que você tem para mim?" (MACHADO, 2004a., p. 44). Para responder à essas questões, a autora recupera a estrutura do conto, subdividida em oito partes, anteriormente, a fim de organizar um roteiro:

\footnotetext{
Elaborando esse roteiro, o contador de histórias pode compreender, de modo significativo o desenrolar da ideia narrativa. As estratégias de elaboração desse roteiro podem ser muito variadas. Ele pode escrevê-lo com frases e depois palavras, pode desenhar cada parte, pode encontrar uma imagem síntese para cada uma delas ou objetos que as representem. Além de um exercício de compreensão inicial, trata-se de um exercício de memorização (MACHADO, 2004a, p. 53).
}

Tive oportunidade de experimentar a elaboração desse roteiro na oficina com a professora Nícia Grillo, citada anteriormente, e repetir a experiência em oficina ministrada por mim, aos alunos da EaD, do curso de Teatro oferecido pela UFG, em 2013. Como resultados dessa turma, das cidades de Catalão, Goiás e cidades vizinhas, na fala de alguns alunos só o roteiro já era suficiente para contar uma história. Outros, porém, concluíram que auxilia muito, mas precisam de mais estudos.

Fabiano Moraes (2012) oferece sua experiência na preparação do conto indicando, igualmente, resumir o texto, em um roteiro com palavras individuais, com base em lista ou organograma. As abreviações servirão para manter o fio da história. 
Diante das várias experiências e respostas dos alunos, posso concluir que ao realizar as várias formas de leitura apresentadas, sem necessariamente ter de passar por todas, é bem provável que a história já esteja pronta para ser contada, mas, só ficará madura depois de recontada várias vezes, em voz alta, de preferência, para alguém disposto a ouvir. Minha experiência mostra que a emissão do som interfere, diretamente, no ritmo e acesso à memória. Tenho a história toda na minha cabeça, mas é comum tropeçar e querer fazer diferente, em certos trechos, quando pronunciadas as palavras em voz alta. Só a experiência pode diminuir essa distância e trazer o domínio entre o pensar e o falar.

O contador que se exercita em grupo, tem a oportunidade do feedback dos colegas, antes de apresentar a história a um público aberto. Quando contamos com o outro, experimentamos as reações dos ouvintes, sobretudo, pelo olhar, e temos a sensação de que a história está pronta para ser contada, com isso, vem a certeza e a segurança que tranquilizam o contador. Entretanto, na falta de um grupo, o exercício pode ser feito solitariamente ou se utilizando de: família, amigos alunos, enfim, pessoas que estejam dispostas a ouvir e comentar a respeito das possíveis interações entre ouvinte e contador.

Aproveitar qualquer intervenção ocasional da plateia, dando maior verossimilhança à história, exige do contador estar com seu texto muito bem internalizado, como se tivesse vivenciado, na realidade, aqueles fatos, para não se perder. A interação é facilmente conquistada, quando o contador acrescenta, na narração da história, alguma reação da plateia, como se esta fizesse parte do conto. O fato é que não há, nem precisa haver um consenso. Alguns consideram mais fáceis as histórias orais, pois o contador conta com suas próprias palavras, não sendo difícil acrescentar ou modificar algum trecho. Outros preferem as histórias autorais, escolhendo as palavras do autor, mas, quando possível, o contador deve aproveitar a oportunidade de compartilhar com seu ouvinte, ainda que necessite trocar alguma palavra, desde que resguarde o sentido do texto.

Um exemplo para essa última situação: certa vez, eu estava contando 'A Verdadeira História dos Três Porquinhos', de John Scieszka (2005), ilustrada por Lane Smith, editora Companhia das Letrinhas, em um espaço que se chamava 'Fornada de Histórias'. Em um determinado trecho da história, o texto é assim: "Olha, não é culpa minha se os Lobos comem bichinhos engraçadinhos como coelhinhos e porquinhos. É apenas o nosso jeito de ser. Se os cheeseburgers fossem uma 
gracinha, todos iam dizer que você é mal" (2005, p. 3). Acontece que, naquele momento, o espaço foi invadido por um enorme cheiro de pão de queijo, que estava sendo assado para ser distribuído aos presentes, ao final da 'fornada de histórias'. Num momento de percepção e improviso eu mudei o texto de "cheeseburger" para "pão de queijo", trazendo, ainda mais, as pessoas para dentro da história e aproveitando a ocasião. Todo contador é um improvisador e deve estar atento às possibilidades que the aparecem.

Em qualquer tipo de história escolhida, o estudo e a paixão são fundamentais. Nas oficinas que realizei, os exercícios práticos e lúdicos desenvolvendo as várias formas de leituras foram comentados pelos alunos, concretizando a troca de experiências e permitindo a sistematização, aqui apresentada. Não há regras ou forma melhor para o estudo de uma história a ser contada. Há, sim, identificação com alguns processos e adaptação/recriação de uma forma própria de estudo.

O estudo do texto vai crescendo, junto à exploração da história e depende do comprometimento ${ }^{131}$ do narrador oral com seus ouvintes, consigo próprio e com o texto escolhido. Porém, o estudo do texto é apenas um primeiro passo, que será preenchido, agora, pelos recursos que a linguagem corporal pode oferecer a cada aprendiz de contador de histórias.

\footnotetext{
${ }^{131} \mathrm{Em}$ minha concepção de Educação, a palavra comprometimento significa compromisso mais conhecimento, características fundamentais de um professor educador.
} 


\section{CAPÍTULO 5 - AS TÉCNICAS DA LINGUAGEM CORPORAL: do contador de histórias}

Os limites da minha linguagem denotam os limites do meu mundo.

Wittgenstein

Entender as técnicas que envolvem o contador de histórias, na perspectiva aqui proposta, significa conhecer, aceitar e ampliar os limites do corpo do narrador oral, conhecendo e explorando suas potencialidades de interação em seus aspectos individuais e, ao mesmo tempo, nos aspectos comuns a todos os narradores. Ao propor um estudo das técnicas da linguagem corporal utilizadas na contação de histórias, concordo que "antes de querer saber como contar, é preciso compreender que as técnicas resultam de um processo de elaboração de presença" (MACHADO, 2004a., p. 69). Presença realizada na interação entre contador e ouvinte, na comunhão do conto, por meio da memória, imaginário, emoção e espontaneidade, apontadas anteriormente. Portanto, não tem sentido uma técnica aprendida de fora para dentro, sem uma compreensão maior de seus significados mais profundos e mais internos, explicados por Regina Machado:

A figura do rei, sua voz, olhar, gestos e, principalmente, sua respiração,
nasce de um lugar interno onde o contador de histórias experimenta a
qualidade da nobreza e da generosidade, como uma recordação. (...) É pela
atualização dessa lembrança que ele dá vida ao rei. E assim,
generosamente, o contador de histórias torna-se presente, presenteando a
audiência com o gesto amoroso, luz lembrada, que é ao mesmo tempo um
convite à recordação de cada ouvinte (2004a., p. 50).

A interação que se faz na presença do contador está, por exemplo, na imagem/significado de rei, construída pelo contador e pelo ouvinte, cada um à sua maneira. Essa construção pede ao contador uma investigação de si mesmo, de seus conhecimentos internos, que são aproveitados como recursos para narrar. O perigo está em pensar que existe um "jeito certo", uma técnica correta que poderia servir de modelo. Como diz Cléo Busatto:

Contar histórias pressupõe deixar de lado algumas técnicas pedagógicas aprendidas e ir em busca de algo que foi esquecido, e que permanece em algum lugar no nosso ser, como um conteúdo arquetípico, recebido de herança dos nossos antecessores (2012, p. 11). 
Deste modo, entendo que as técnicas do contador de histórias se desenvolvem na perspectiva das possibilidades de conhecimento e ampliação de sua própria capacidade de lidar com a linguagem de seu corpo e de seus recursos de linguagem. Para isso, se faz imprescindível o autoconhecimento, por meio de experiências de descobertas das potencialidades pessoais de cada contador, ainda que vivenciadas coletivamente.

Cada um conta de uma forma particular, combinando com suas características pessoais. Segundo Busatto (2012) essas características fazem parte de nossa natureza, "trazemos de herança da nossa história de vida, é nossa propriedade e devemos tratá-la com carinho, pois estas peculiaridades que farão a diferença" (2012, p. 89). Pensando dessa maneira, acolho com carinho cada lembrança suscitada pelas histórias que conto, e pelas histórias dos alunos contadas em sala de aula.

Considerando minha prática educativa, com base nas teorias dialógicas, encontrei em Regina Machado pergunta semelhante a que faço aos meus alunos contadores, antes de abordar as especificidades das técnicas da linguagem corporal: "Como posso me preparar, ou seja, o que posso aprender, para que eu mesmo encontre respostas para minhas perguntas?" (MACHADO 2004a., p. 69). A ideia é de que, conhecendo bem as potencialidades da linguagem corporal, 0 contador possa construir melhor suas técnicas e aplicá-las em sua performance.

Embora os recursos apresentados sejam interdependentes e orgânicos, a necessidade da verticalização do conhecimento impõe uma separação provisória, em que a própria redação mostra as dificuldades de isolamento dos termos, entendidos sempre em seu conjunto. Celso Sisto (2012a) nomeia os elementos ou recursos dos contadores como regras da verossimilhança: voz, gestos, olhar e preparação. E, para contar melhor, sugere, também, outros elementos: emoção, texto, adequação, corpo, voz, olhar, espontaneidade/naturalidade, ritmo, clima, memória, credibilidade, pausa e silêncio e elemento estético. As semelhanças de nossos estudos e experiências podem ser explicadas pela influência deste autor, no início de minha participação em um grupo de contadores, pois o Gwaya foi formado a partir de uma oficina do Proler, com Celso Sisto.

O resultado da sistematização, aqui apresentada, é fruto da reflexão realizada com base em um "quadro de recursos" (anexo 1), utilizados nos cursos e oficinas 
para formação de contadores, passando por transformações, ao longo dos últimos dez anos. O referido quadro pode ser considerado, de certa forma, como hipótese no desenvolvimento dessa pesquisa no entendimento dos recursos da linguagem corporal dos narradores, por ter servido tanto tempo de referência em minha prática. Entretanto, no momento da sistematização e teorização, se revelou ineficiente, sobretudo, no entendimento dos parâmetros do som e dimensões acústicas dos estudos de César Lignelli (2011), e Sílvia Davini (2007), determinando as alterações, sobretudo, nos termos correspondentes às vocalidades.

Outros contadores mostram entendimentos semelhantes, que podem contribuir na compreensão do entendimento de corpo na narração, como por exemplo, Laura Simms, quando diz que: "A narração de histórias é tão potente porque é uma experiência física. A pessoa inteira engaja na feitura do significado e da história"(2004, p. 61). É o corpo todo que fala, que se expressa por meio de sua linguagem, de sua expressão.

Da mesma forma, para Cléo Busatto, "O contador de histórias empresta seu corpo, sua voz e seus afetos ao texto que ele narra, e o texto deixa de ser signo para se tornar significado" (2012, p. 9). Significados que compreendo se realizarem por meio de recursos da linguagem corporal do contador.

$\mathrm{Na}$ busca pelos autores contadores de histórias que contribuem na formação de outros contadores, me detive na fala de Gislayne Matos:

\footnotetext{
O "instrumento" essencial na arte de contar histórias é o corpo do contador (gesto e voz). Na oralidade, comunica-se com todo o corpo e não apenas pela voz. No caso da voz, o ritmo, a tonalidade, as interpretações vocais, a entonação ajudam a compor os cenários e a criar atmosferas que serão oferecidas ao ouvinte. Do corpo vêm os gestos, que não são uma "ilustração redundante" do que se está dizendo (2012, p. 121).
}

Embora concorde com a autora, no uso do corpo por meio dos elementos citados para a composição do clima da história e, de que os gestos não são ilustrações redundantes (como discutiremos mais à frente), discordo do corpo como "instrumento", acreditando ser o corpo o sujeito de si mesmo. O contador é seu corpo, e não, tem o seu corpo como ferramenta. Esta, parece-me uma visão mecanicista e utilitarista que não se ajusta nem corresponde à visão de arte aqui considerada. 
Os estudos sobre corpo são desenvolvidos por várias áreas do conhecimento e da ciência, sob múltiplas perspectivas e objetivos, sendo o interesse desta investigação as ações que envolvem a linguagem corporal em sua expressão oral. Portanto, um corpo voz em movimento e envolvimento de alguém que fala, com pelo menos uma escuta ou audiência. Na busca por uma compreensão de corpo, verificamos a existência de vários conceitos, por vezes, antagônicos, suscitando amplos debates sobre um corpo uno, orgânico e a superação de entendimentos que revelam dicotomia entre corpo e mente.

As áreas de investigação que subsidiam e influenciam meus estudos e entendimentos sobre corpo tiveram início na área da Educação Física, voltada para o entendimento das várias manifestações da cultura corporal, como foco central para o entendimento do papel do professor no ensino básico. Ainda que essa realidade esteja um tanto distante das escolas brasileiras, as concepções filosóficas, sociais e antropológicas das leituras e debates realizados na graduação e pós-graduação, me propiciaram entendimentos e vivências importantes sobre o corpo, que são complementadas por estudos mais recentes (em meu conhecimento e apropriação) na área das artes cênicas e arte-educação.

Historicamente, identificamos diferenças culturais nas maneiras de entender, pensar e agir sobre o corpo. Para Platão ${ }^{132}$, o corpo podia ser considerado como cárcere da alma. O mundo ocidental, berço de nossa cultura, reforça essa dicotomia que, aos poucos, vai impregnando o pensamento social, chegando a ser expressa no senso comum. Podemos perceber isto em alguns ditos populares: "Quem não tem cabeça pra pensar tem pernas para andar" "Quem vê cara não vê coração", "Mens sana in corpore sano", e outros. Vários estudos ${ }^{133}$ investigam alterações na imagem corporal, assim como nas formas de entender e movimentar o corpo, mais especificamente na passagem da ldade Média para a ldade Moderna e contemporânea, como consequência das revoluções industriais e outros fatores, que modificaram os comportamentos das sociedades ocidentais. Entretanto, este pensamento eurocêntrico e fragmentado que parece dominar o século $X X$, na maioria dos setores, encontra hoje muitas oposições e compreensões em outras direções, permitindo entendimentos e ações distintas, sobretudo no campo das

\footnotetext{
${ }^{132}$ No texto: O Mito da Caverna, encontrado no livro: A República de Platão.

${ }^{133}$ Michel Foucaut; Carmen Lúcia Soares (1998); Ana Márcia Silva (2001); Heloisa T. Bruhns (1989); Wagner Wey Moreira (1995).
} 
artes. E, acredito, como Cléo Busatto, que contar histórias é uma arte! "Insisto: contar histórias é uma arte, e o contador de histórias é um performer, um homem de ação" (BUSATTO, 2012, p. 80). O entendimento de corpo influencia nas ações desse sujeito, ou seja, na maneira pela qual se compreende cada corpo, incitando o contador a agir de acordo com esta compreensão. Eliana Stort contribui ao afirmar que:

\footnotetext{
O mundo humano, como o dos animais, começa com o corpo, pois tudo o que o homem criou foi em meio à luta para sobreviver, pelo benefício. $\mathrm{O}$ corpo como centro estruturante e matriz emocional do homem, tem prioridade axiológica - é fundamento e deve ser meta do mundo humano (...) Os sentidos estão encarnados no corpo que é transformado pela cultura. Com a cultura e o seu desenvolvimento, o corpo se transfigura a si mesmo (STORT, 1989, p. 22).
}

Essa capacidade de transfiguração vinculada à cultura mostra a capacidade de aprendizagem do corpo humano, sobretudo, quando este se assume como sujeito de suas ações. Nesta direção, percebo que as técnicas conectadas às ações corporais são descobertas individuais, como afirma Regina Machado: "a técnica é a escolha de um determinado modo de contar, a partir de uma intenção, e levando em consideração, além dos recursos internos, outros tipos de recursos que possam ser descobertos pelo contador de histórias" (MACHADO, 2004a., p. 74).

Se a técnica é um recurso a ser aprendido, concordamos, também, de que não é preciso dom ou talento para se contar histórias, e sim, a prática. Nesse sentido, Busatto deixa um recado: "Gostaria de deixar expresso a minha crença de que contar histórias não é um privilégio de poucos, e sim uma tarefa acessível a quem se dispor a desenvolvê-la. Afinal, a prática ainda é o caminho mais seguro" (BUSATTO, 2012, p. 90). E essa prática é que determina os caminhos que cada contador segue, construindo suas próprias técnicas.

Muitas são as formas que podem ser empregadas em uma narração de histórias, sendo que as escolhas vão depender tanto do conhecimento do contador sobre si mesmo, em relação às potencialidades dos recursos corporais que consegue explorar, quanto do que o texto oferece e consegue ser percebido pelo narrador. O ator e contador de histórias Mauro Brant, no meu entendimento, apresenta pistas para o estudo desses recursos, na citação a seguir: 
(...) o contador de histórias urbano elegeu seu acervo a partir das muitas possibilidades que sua história de leituras oferece, textos autorais, poesias, crônicas e também histórias da tradição oral que reencontramos nos livros. Afinal ler é sempre escutar uma voz. Ao escolher um texto para contar o narrador vira dono dessa voz. Ele tem o dom de saber escutar e sentir os movimentos subjacentes ao texto. As leis da cena ajudam no processo artístico, administrando essas reverberações e as transformando em algo expressivo. A memória (e não só a memorização) age como cocriadora do texto que é incorporado pelo narrador. Assim, o conto vira carne, sangue, gesto, olhar, escuta, suor, respiração; ou seja,corpo; e especialmente voz, sua principal emanação (BRANT, 2011, p. 68/69, grifo meu).

Descobrir a voz da história, as leis da cena (com suas possibilidades de reverberação e expressividade), o envolvimento da memória cocriativa, entender os sentidos incorporados na carne, a escuta, os gesto, o olhar e os recursos envolvidos na narração, pressupõe o entendimento de corpo e de técnica, para que cada contador possa criar sua performance, com base em sua própria vivência e criação.

A investigação dos recursos ou elementos, por meio de conceitos, definições e exemplos busca mostrar suas relações, interligações e formas de apropriação para sua utilização na narração de uma história. O foco, agora, são as potencialidades do uso do corpo nas possibilidades de interação do contador com seu ouvinte, por meio dos aparelhos fonador e motor, e tudo o que envolve, as diversas técnicas corporais aplicadas pelos narradores.

Correndo o risco de parecer dicotômica e fragmentada, mas, ao mesmo tempo, consciente de que uma decupagem ${ }^{134}$ pode esclarecer e ampliar a visão do todo, investigo as técnicas da linguagem corporal do narrador, por meio de características da oralidade, da gestualidade e do ritmo, que foram se destacando, ao longo de minha prática como contadora e formadora. São recursos técnicos da linguagem corporal, que orientam a narração de histórias e que foram subdivididos para fins de aprofundamento. No entanto, alerto para o fato de que esses elementos não são isolados, se misturando na própria redação pela exigência da compreensão de sua interdependência. A esses três subitens, seguem-se outros subsequentes, que envolvem a prática dos exercícios na aprendizagem de contar histórias, desenvolvidos em minha experiência de formação, sempre considerando a presença da manifestação lúdica como fundamento dos exercícios, de descoberta e de treinamento.

\footnotetext{
${ }^{134}$ Utilizo o termo decupagem no mesmo sentido usado no cinema, por Ismail Xavier, em: O discurso cinematográfico: a opacidade e a transparência.
} 


\section{1 - Oralidade}

A oralidade pode existir sem a escrita, mas a escrita não pode existir sem a oralidade.

llan Brenman

Embora o interesse neste momento do estudo seja a oralidade, em seu uso na narração de histórias, não há como desvincular suas relações com a escrita, em razão do sujeito demarcado pela pesquisa ser o contador aprendiz, que participa do mundo letrado, de hoje. A aprendizagem desse contador envolve o deslocamento, ou a transferência da linguagem escrita para a linguagem oral, considerando a multiplicidade do repertório existente e as experiências de oralidade do sujeito contador.

As relações da oralidade interrogadas e observadas pelo narrador, em busca de sua performance, se caracterizam pelas produções vocais e sonoras em seus significados. Para este entendimento, Walter Ong (1998) esclarece que a oralidade abrange "desde o choro de um bebê com fome, até o monólogo psicanalítico e filosófico dos seres humanos" (p. 159), esclarecendo, ainda, ter sido bastante estudados, depois da passagem da oralidade para a escrita (sobretudo no gênero narrativo). Aplicando o entendimento desse autor na ação do contar, compreendo que toda a produção sonora vocal exercida pelo narrador, pertence à oralidade e, compreender e conhecer o seu contexto auxilia na elaboração das escolhas dos sons de uma história. Eliana Yunes entende que:

\footnotetext{
Havia uma oralidade primária, viva até hoje, nos ditados populares, nos trava-línguas, nas adivinhações, nas rezas e celebrações que se impunham quase rituais, por trazerem o "espírito" daquilo que invocavam ou rememoravam. O que lhes permitia não confundir as oralidades, nem se esquecer das "fórmulas", era justamente a forma, isto é, as marcas específicas de ritmo, ressonância, as imagens e as figuras que recordavam a experiência, o vivido. Essa oralidade era guardada no coração, "de cor" (YUNES, 2012, p. 62) grifos meus.
}

Por outro lado, Zumthor (1993) e outros autores, identificam que no mundo de hoje não há mais espaço para essa oralidade primária, pelo menos, em nosso mundo letrado. No entanto, percebe-se a existência da oralidade nas sociedades atuais, tanto no cotidiano, quanto em rituais e outras manifestações, incluindo a 
narração de histórias para as quais Yunes aponta marcas específicas como ritmo, ressonância e outros, que são características importantes a serem compreendidas, como recursos técnicos para a eficiência da narração.

Gilka Girardello (1998) apresenta contribuição de Adélia Meneses, entendendo que "na narrativa oral a palavra falada carrega sempre uma carga corporal (...) É a coordenação da voz, da alma, do olho e da mão que para Walter Benjamin era característica da narração oral artesanal"(ibidem, p. 67). Por meio dos estudos da autora percebo que os entendimentos de recursos corporais envolvidos na oralidade auxiliam o contador na preparação e na ação de contar história.

Vários autores corroboram com a ideia do uso de recursos da oralidade na narração de histórias e, cada um a seu modo e relacionando sua experiência, nomeia ou estrutura essas características de formas diferentes. Elvira Perez, por exemplo, diz que: "O narrador oral conta a história usando a gestualidade, o tom de voz, o olhar ou o movimento" (PÉREZ, 2012, p. 194). Embora os autores não se detenham em cada ponto, ou em cada recurso, nos diálogos e entrelinhas é possível a construção dessa compreensão. E, este é o desafio aqui proposto.

Segundo Celso Sisto,

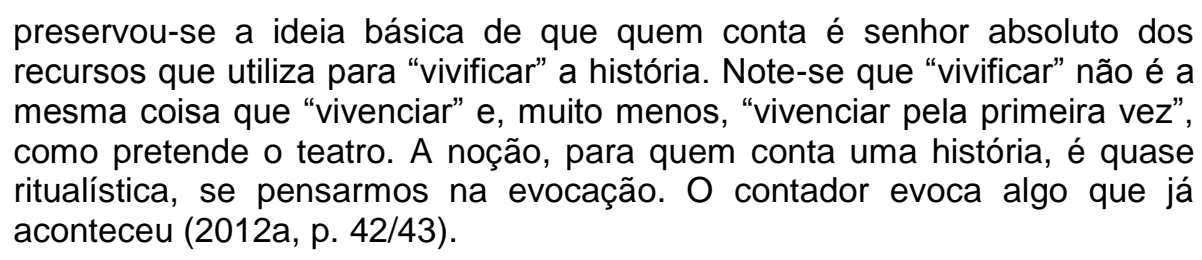

A evocação, no meu entendimento, é uma característica da ancestralidade a qual pertence à oralidade explicada por Lenice Gomes, em sua complexidade e importância: "A oralidade é uma das mais antigas guardiãs da sabedoria popular, sabemos que ela tem o poder do ensinamento, da diversão, da cura e da linguagem" (GOMES, 2012, p. 29). Essa é uma compreensão subjetiva que, no meu entender, é o pano de fundo da discussão sobre as diferenças entre atuar e contar histórias.

Segundo Paul Zumthor (2007), o teatro é o modelo absoluto da oralidade artística e é neste aspecto de performance que a formação do narrador oral se aproxima da formação do ator. Ainda que sejam atividades diferentes, muitos aspectos se assemelham, na utilização das mesmas fontes e "instrumentos". 
O contador Sérgio Bello (2004) utiliza a narração oral, "entendida como "oratura": um espaço de recriação simbólica e estética, que ganha sentido como troca entre artista e público, a exemplo de outras artes, numa relação direta"(ibidem, p. 159). Entre os contadores da atualidade começam a surgir estudos, definições e conceitos em torno do termo 'oratura'. Conceito que prefiro deixar de lado, neste momento, para conseguir manter o foco proposto no entendimento de como a linguagem corporal oferece técnicas para a narração.

Portanto, para o desenvolvimento das técnicas de narração oral, no que diz respeito à produção vocal, o primeiro elemento que me chama a atenção é a palavra.

\subsection{1 - A palavra: matéria prima do contador.}

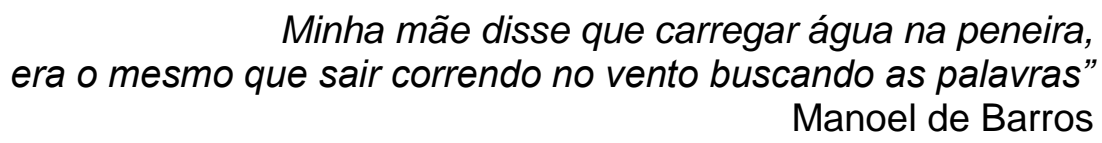

O amor à palavra é uma virtude; seu uso, uma alegria.

Paul Zumthor

A palavra é a matéria prima do contador de histórias. É o primeiro recurso de que dispõe o narrador oral para o seu trabalho, portanto, é em sua essência que o contador de histórias busca fundamento.

Muitas palavras possuem acepções múltiplas sendo, muitas vezes, identificadas pelos recursos aplicados pelo contador, no contexto da narração. Ao escolher a palavra como material para sua criação, o artista narrador sente cada vocábulo com sua forma, cor, cheiro e sabor específico. Se o escritor é alguém que trama fios e cores, criando formas em suas narrativas, os contadores de histórias misturam a essas formas e cores os cheiros e os sabores das venturas e desventuras que vão narrando. O corpo vai desenhando e musicando a história, que penetra na sensorialidade ${ }^{135}$ do ouvinte, provocando respostas múltiplas. É assim, o contar com! "A criação da beleza pode se dar em palavras, com a força de quem refaz o mundo no espírito, no mistério, no humor, na maravilha, e depois abre a

\footnotetext{
${ }^{135}$ Relativo aos sentidos básicos do ser humano, presentes em qualquer obra e evento artístico, segundo, João Francisco Duarte JR - Fundamentos estéticos da educação, 1998.
} 
porta para o insuspeitado" (SISTO, 2012a, p. 24). Nesse sentido, a palavra é explorada pelo contador em todas as suas possibilidades e subjetividades, elucidada por Celso Sisto:

\begin{abstract}
A palavra, com seu poder de evocar imagens, vai instaurando uma ordem mágico-poética, que resulta do gesto sonoro e do gesto corporal, embalados por uma emissão emocional, capaz de levar o ouvinte à uma suspensão temporal. Não é mais o tempo cronológico que interessa e, sim, o tempo afetivo (ibidem, p. 32).
\end{abstract}

A manutenção desse tempo afetivo é conquistada pelas imagens formadas durante a narração do conto, discutidas no terceiro capítulo. Para Busatto, "narrar significa também a capacidade de traduzir oralmente as imagens contidas no texto" (2012, p. 53). A autora explica que fugir de versões simplificadas e aprender a valorizar as palavras que provocam imagens, faz parte da preparação do conto.

A tarefa do contador é perceber as nuances de cada palavra, valorizando-as em toda sua potencialidade. Ao estudar o texto, o contador presta atenção nas palavras, procurando visualizá-las, formando uma imagem concreta correspondente. O contador toma consciência de sua fala, ao mesmo tempo que formula as imagens dos objetos, cenários e ações em que se desenvolve a narrativa. Dessa forma, as palavras se tornarão mais significativas para quem ouve que complementa seus significados, formulando suas próprias imagens, com base em suas próprias experiências, conforme Bachelard (1988).

Confiar em sua própria experiência fortalece a narração oral, pois, de acordo com Gislayne Matos:

\footnotetext{
Muitos acreditam que as belas palavras habitam o território dos escritores e brotam das páginas dos livros. Assim apresentam grande dificuldade em descolar-se do texto escrito, fonte de sua pesquisa, para ousar reconstruí-lo na oralidade partindo das próprias experiências para se expressar, usando as palavras que fazem sentido para eles e saboreando as mais prazerosas de se dizer (MATOS, 2012, p. 120).
}

O contador de histórias é um grande colecionador de palavras. Por isso, tem um amplo repertório de leituras! "Muitas vezes a dificuldade em se expressar por palavras provém da ausência de familiaridade com a ausência lógica de pensamentos, e a leitura pode auxiliar neste caso" (BUSATTO, 2012, p. 90). O gosto pelas palavras e pelo improviso, a curiosidade por novos vocábulos e pesquisas nesta direção foram sempre objetivos desenvolvidos nos cursos e oficinas, como 
recurso para a elaboração da performance do contador de histórias. Completar frases ou histórias, acrescentar palavras, inventar verso ou prosas, charadas, brincar com as sílabas, prestar atenção em detalhes, relembrar repertórios individuais das oralidades da infância, como: parlendas, cantigas, adivinhas e outras, foram atividades apontadas pelos alunos (em avaliações orais ou escritas) como coadjuvantes da melhora na capacidade de improviso com as palavras.

O narrador oral é também um cuidador das palavras!

Construir liberdade para lidar com as palavras, sobretudo no improviso, exige conhecimento e experiência. Para nós, do mundo letrado exige leitura de um lado e saber ouvir de outro. O repertório de palavras do contador é algo ilimitado que transita em vários mundos e culturas, da literatura oral à escrita, sem desconsiderar que leitura é também observação e compreensão de mundo. Há que se perceber as variações nos estilos para não empobrecer a linguagem, pela falta de vocabulário adequado. Como cuidador das palavras, ele preserva o estilo do autor, ou da história, construindo imagens por meio da organização dos vocábulos, formulando sentidos.

Como colecionador e cuidador das palavras, o narrador oral tem sempre uma nova forma de apresentar as mesmas ideias, sem ficar repetindo os vocábulos e garantindo o envolvimento da maioria dos ouvintes. As palavras, por sua vez, são expressas pela voz com suas possibilidades de produção sonora.

\subsection{2 - A voz de quem conta histórias}

A voz é querer dizer e vontade de existência. Zumthor

O narrador oral compartilha suas histórias, por meio de sua voz, que do meu ponto de vista, neste contexto, é entendida como ação corporal, por meio de uma linguagem. Compreendo-a como uma produção sonora, que realiza uma ligação entre o interior e o exterior, ou seja, entre o que vem de dentro do contador e consegue alcançar o ouvinte.

$\mathrm{Na}$ explicação de Paul Zumthor "Toda voz emana de um corpo (...) que permanece visível e palpável enquanto ela é audível”(1993, p. 241). 
Nesta direção, Grotowski foi um dos primeiros estudos da área de teatro que encontrei identificação, concordando com seu pensamento: "A voz é uma extensão do corpo, do mesmo modo que os olhos, as orelhas, as mãos: é um órgão material, que pode até mesmo tocar" (GROTOWSKI, 2007, p. 159). Entendo esse tocar como uma carícia, ou embalo no início do sono (na figura da mãe ou de uma ama); uma compreensão que transforma algo no ouvinte (mudanças que podem ser profundas e perenes); ou a formação de imagens e emoções suscitadas pelo conto, por isso, associo ao narrador.

As características de individualidade da voz humana são constituídas tanto pelas condições biológicas, quanto pela experiência cultural de cada um, resultando em aspectos semelhantes e diferentes, ao mesmo tempo. Este entendimento, por si só, indica caminhos para que o narrador oral explore o potencial do seu aparelho fonador, com possibilidades de transformações, como revela a pesquisa de Terezinha Zaratin:

\footnotetext{
Embora a fonação seja uma função neurofisiológica inata, a voz é o resultado da vida de cada indivíduo, e grande parte desse processo é realizada por desejo de comunicação e imitação de padrões, e pode ser educada e desenvolvida (2010, p. 24).
}

A voz pode ser educada em seus parâmetros do som, como comprova a tese de César Lignelli (2011), professor do Departamento de Artes Cênicas da UnB. Para um conhecimento mais aprofundado das potencialidades de sua voz, o contador estuda seu "aparelho fonador ${ }^{136 ", ~ t e m ~ o ~ a p o i o ~ d e ~ f o n o a u d i o ́ l o g o s ~ e ~ d e ~ p r o f e s s o r e s ~}$ de canto e fala ${ }^{137}$, como parte do conhecimento biofisiológico. A tese do referido professor tem o alcance de toda a sonoridade da cena, sendo aplicados para a construção do contador de histórias, os estudos dos parâmetros sonoros.

Concordando com a contadora Estrella Ortiz, "o estilo, a voz única do narrador, chega como resultado de suas buscas e de suas descobertas, em um processo de contínua evolução" (ORTIZ 2004, p. 110). A voz de cada pessoa pode ser modificada, em certa medida, com limitações fisiológicas individuais. E, são essas possibilidades de controle da voz que busco em Lignelli (2011).

\footnotetext{
${ }^{136}$ Aparelho fonador - composto pelos sistemas articulatório, fonatório e respiratório, pode ser estudado em livros de fonoaudiologia e/ou medicina, depende do interesse de aprofundamento desejado.

${ }^{137}$ Para aprofundar as pesquisas neste tema: César Lignelli; Sílvia Davini; Terezinha Zaratin.
} 
Pude verificar no contato com muitos contadores (experientes ou iniciantes), que algumas pessoas têm mais facilidade e lidam com a voz, explorando, com riqueza, a sua caixa de ressonância e timbres diferentes. Outros, demonstram maiores dificuldades na produção de variedades sonoras. Cada um explora suas necessidades e curiosidades, de acordo com seu interesse individual e possibilidades, pois esta é a direção da autonomia a ser construída pelo contador.

A compreensão nos modos de fala, em sua distinção, atua na autonomia dos contadores do mundo contemporâneo, explicada por Eliana Yunes:

\begin{abstract}
Pensadores contemporâneos (...) voltaram sua atenção para os modos da fala e seu lugar como expressão viva de um corpo, um desejo, uma presença. A voz em suas contingências táticas, seu desempenho, sua improvisação, aproximam, para Sílvia Davini (2007), o ver, e o dizer de modo que estabelece uma interdependência entre o visual e o acústico. Por isso, contar estimula o imaginário tanto quanto a leitura e devolve à fala um lugar valorado nas trocas sociais (YUNES, 2012, p. 74).
\end{abstract}

Por isso, o estudo da linguagem corporal, de uma voz, expressa por um corpo que narra, por meio de uma produção sonora. Nesse sentido, o contador, objeto desse estudo, procura nas possibilidades de produção sonora os recursos vocais para sua narração, por meio dos parâmetros do som e das características da fala.

\title{
5.1.2.1. Parâmetros do som
}

Ao eleger os estudos de César Lignelli (2011) como base para a compreensão das técnicas vocais, aceito as propriedades do som por ele levantadas, assumindo os conceitos que se aplicam na elaboração de técnicas vocais para uma narração. Considero, como o autor, que: "com o domínio isolado do que pode ser alterado nos sons, podemos implementar mudanças das mais sutis às mais explícitas com mais precisão, nuances e possibilidades formais e estéticas" (LIGNELLI, 2011, p. 91). Isto significa que, por meio do controle dessas características dos sons o contador pode explorar universos sonoros diferentes, a fim de atrair o ouvinte para sua história.

Os termos parâmetros, característica e propriedade serão, neste contexto, admitidas como sinônimos, seguindo ainda o mesmo autor. De acordo com ele, o controle dos parâmetros, conquistados por meio de práticas, pode permitir: ouvir, 
perceber e mudar, "uma vez que ouço, identifico o que me incomoda, possuo meios conceituais e práticos e o desejo de mudar (ibidem, p.91). A investigação do contador vai à direção da identificação das possibilidades de uso dessas propriedades dos sons. Deixo claro que, em sua pesquisa, o autor esclarece e considera outras abordagens em relação à produção de sons, como por exemplo: com características físicas (acústicas); como percepção - psicoacústica; com sua função e significado, fundamentados na semiótica e semântica; nas qualidades emocionais ou afetivas que se relacionam à estética; e, no efeito produzido em determinado contexto, a pragmática. Embora estas abordagens não sejam excludentes, e, sim, concomitantes, aceito o interesse pela pragmática escolhido pelo autor, por ter como foco variações possíveis na voz do contador, durante a narração de uma história.

Assim, ao redefinir ou aceitar os conceitos do autor para cada parâmetro do som, procuro exemplos em minha prática de contadora e formadora de contadores, que corroboram com os entendimentos para a elaboração de vozes e sons em uma narração de histórias. Ou seja, como esses parâmetros podem interferir na produção sonora de uma narração.

\section{a. Ruído e silêncio}

O ruído é exposto por Lignelli como: "aquele som que desorganiza o que queremos ouvir, abrindo outros focos e sentidos indesejados" (2011, p. 98), alertando para variações de interpretação nos contextos diversos. O ruído, em uma contação de histórias, equivale a um som que atrapalha a audiência e, às vezes, com uma interferência tal, a ponto de impedir o contador de continuar sua narração.

Certa vez, em Goiânia, contando histórias em uma escola municipal, em sala de aula, fui pega de surpresa com uma frase da professora, em voz alta, no meio da narração: - "liiichxxx... soltaram o infantil". O que se seguiu foi um ruído externo tão intenso, que, do meu ponto de vista, inviabilizou a continuidade da história. As janelas das salas de aula eram voltadas para o pátio (como na maioria das construções das escolas municipais de Goiânia). O que era para ser uma viagem por novas sensações e aventuras se transformou num imenso esforço, de ambos os lados, contador e ouvintes, sem o silêncio mínimo necessário para que as palavras fossem impregnadas de sentidos, dados pelo contador e pelos ouvintes, na 
comunhão do conto. Terminei do jeito que foi possível e mudei a atividade, até ser possível a retomada da sessão de histórias, que ficou perdida. Na retomada o clima era outro e a professora tinha outros planos e outras atividades (mais importantes). Em minha opinião, faltou conhecimento para planejar e dar o valor que a atividade merecia.

O silêncio é então um parâmetro de som importante a ser considerado numa contação de histórias, a ponto de impedir seu acontecimento, sem silêncio não há história.... Assim, concordo com o pensamento de Lignelli:

\footnotetext{
O silêncio torna-se cada vez mais valioso, na medida em que se encontra mais distante de nós, em meio aos sons industriais, carros esportes, rádios, transistores, etc. É fundamental percebê-lo, respeitá-lo, cultivá-lo... e rompêlo, é claro, sempre que necessário! (2011, p. 90).
}

O contador de histórias exercita esse domínio de suscitá-lo, para iniciar uma história e irrompê-lo com suas palavras, abrindo as portas ao mundo imaginário. $\mathrm{O}$ silêncio e a pausa são valiosos recursos, trabalhados na preparação vocal de uma história, influenciando, diretamente, no ritmo da história, considerado por Lignelli (2011) como um dos parâmetros do som, desenvolvido neste estudo em item específico, por sua importância e contribuição na elaboração da narração de uma história.

\section{b. Intensidade, frequência, timbre e ritmo}

Percebo que estes quatro parâmetros do som, estudados por Lignelli (2011): intensidade, frequência, timbre e ritmo têm aplicabilidade direta na produção vocal do contador, sendo utilizadas para diferenciar vozes dos personagens e do narrador, ao lado de outras características da fala, desenvolvidas no próximo subitem. Não que seja obrigatório fazer vozes diferentes para se contar uma história, mas é um recurso disponível ao conhecimento do contador aprendiz, caso este tenha interesse.

Mais do que ficar conceituando ou definindo cada um desses parâmetros, tarefa já realizada por César Lignelli (2011), busco a compreensão da produção das alterações vocais que auxiliam na diferenciação de produções sonoras para narração do conto. 
O aumento do som é proporcionalmente equivalente ao aumento de intensidade na explicação de Lignelli, para quem a intensidade "consiste em informações sobre certo grau de energia da fonte sonora" (2011, p. 111). É considerada como um dos sete elementos da música (junto com altura, o ritmo, a melodia, a harmonia, o andamento e a métrica), cujas relações com a narração, do meu ponto de vista, mereceriam um estudo à parte, pois identifico alguns desses elementos na fala, nos jogos e brincadeiras trabalhados nas oficinas, exemplificados no decorrer da tese.

Segundo Lignelli (2011), aumentando a frequência de um som, muda sua percepção, ainda que a intensidade seja mantida (fácil de perceber na regulagem de uma mesa de som). Aprofundando nas leituras, fica claro que só a prática pode mostrar ao contador os efeitos sonoros provocados pelas variações nos parâmetros vocais, e o autor oferece exercícios à cada parâmetro, mostrando seu funcionamento e treinamento.

O treinamento, segundo o autor, comprovado em sua tese, pode ampliar a percepção da frequência, que é diferente em cada um. Se a intensidade é medida pelo grau de energia e o aumento do som indica aumento de intensidade, percebo, em relação a narração de uma história, que a intensidade da fala pode variar do sussurro ao grito, sendo utilizadas nas dinâmicas de uma narração. Por meio de Lignelli (2011), aprendi que a intensidade varia entre "alto e baixo", enquanto a frequência trabalha com os sons graves e agudos e essa mistura, às vezes, nos confunde. A frequência, segundo o autor, se refere à taxa de vibrações em ciclos de segundo, medida em Hertz. Para o uso da voz, percebo que a vibração dos harmônicos, despertada pela frequência do som, interfere no resultado final. Isso explica porque uma plateia grande não desafina, revelando esse tipo de interatividade entre contador e plateia como um rico recurso de narração, por exemplo, em histórias com músicas cantadas pelo público, suscitadas pelo contador.

O conceito de timbre não é tarefa das mais fáceis, uma vez que há uma multiplicidade de entendimentos, em áreas diversas, embora com objetivos diferentes, por vezes até antagônicos. No senso comum, por exemplo, o timbre se caracteriza como uma qualidade, ou um aspecto específico que distingue um som de outros sons, podendo diferenciar uma voz de outra. De acordo com o dicionário timbre é: 
O efeito acústico proveniente da ressonância [q. v.], e determinado pelo grau de abertura da cavidade bucal, i, e., da distância entre a língua e o céu, distância que é a máxima para o a, a mais aberta das vogais, e a mínima para o $i$ e para o $u$, as mais fechadas (FERREIRA, 1975, p. 1377).

Essa explicação induz a necessidade de entender o que é ressonância ${ }^{138}$, revelando, de imediato, a insuficiência do entendimento do termo e a consequente necessidade do aprofundamento nas investigações.

A professora de estética vocal Terezinha Zaratin (2010), ao pesquisar as funções da voz para uma educação vocal, aponta a importância da classificação desta, para que o usuário conheça seus potenciais e limites, embora faça um alerta em relação à maturidade e desenvolvimento da voz, para a eficácia da categorização proposta. Os profissionais aptos a realizar tal tarefa são: o maestro, o professor de canto, o diretor musical ou o professor de educação vocal, na perspectiva colocada pela referida autora ${ }^{139}$.

Este entendimento tem sentido na música, se caracterizando como insuficiente para o contador de histórias que precisa produzir sons diferentes para os distintos personagens de um mesmo conto. Fazendo com que os ouvintes identifiquem 'vozes' de diferentes personagens.

A prática de contadores de histórias me mostrou que diferenciar o timbre da voz é saber mexer com a fisiologia da garganta, das pregas vocais (na passagem do ar, abrindo ou fechando mais a boca) e da caixa de ressonância, cavidades bucais e nasais, língua, dentes, bochechas. Isso provoca variações na forma de colocar e produzir o elemento sonoro, por exemplo: mais agudo, rascante, sussurrado, grave, etc.

Os estudos de César Lignelli (2011) me revelaram como e porque isso acontece, ampliando ainda mais minhas possibilidades de investigação prática. Segundo o autor, que aprofundou suas investigações na definição de timbre, mostra que "O timbre traz a cor da individualidade aos instrumentos, à música e à voz" (LIGNELLI, 2011, p. 145), indicando que, sem dúvida, este revela a qualidade do som e, para os contadores de histórias, pode diferenciar um personagem de outro. Porém, é a relação entre os harmônicos que, se distribuindo por frequências,

\footnotetext{
${ }^{138}$ Termo que será explorado no item reverberação, considerado como sinônimo.

139 Terezinha Nackéd Zaratin - atriz, cantora lírica e instrutora de teatro em instituições públicas e privadas, com cursos na Europa, Moscou e Estados Unidos, com ênfase na voz.
} 
diferenciam os sons uns dos outros, assim como envolve outros atributos como 0 ataque, fluxo e intensidade, como nos mostra o estudo do autor.

Antes de conhecer essas características do som, que, sem dúvida, ampliam minha possibilidade criativa, minha observação empírica e fontes de inspiração para a elaboração das performances das histórias, foram os dubladores de desenhos animados. Os treinamentos e criação de vozes diferentes foram, e ainda são, brincadeiras que uso em meu cotidiano familiar.

Explorar as possibilidades da voz brincando de fazer sons diferentes, com as bochechas, com a língua, com a garganta, utilizando a caixa de ressonância da cavidade da face, experimentando abertura de boca em tamanhos diferentes, em uma posição que comprime determinada parte do aparelho fonador, enfim, conhecendo possibilidades com todo o corpo, são os exercícios desenvolvidos nas oficinas, que me ensinaram a conhecer minha voz.

O ritmo é analisado por Lignelli (2011) como um parâmetro do som relacionado à duração, à intensidade, altura e timbre, avaliando sua complexidade com base no ritmo corporal individual. Pela importância do tema, apresento-o como característica da linguagem corporal, junto à gestualidade e à oralidade. Portanto, o ritmo é retomado, após a discussão sobre gestos.

Um cuidado observado em poucos cursos é a necessidade de aquecimento vocal, indicado nas bibliografias de música ou teatro, antes de exercícios e exposição prolongada da voz.

Em minha percepção, são os parâmetros: intensidade, frequência, timbre e ritmo, os responsáveis pelas variações sonoras aplicadas nas vozes de diversos personagens: rascante, suave, forte, grave, sensual, doce, estridente, melosa, melodiosa, etc.

\section{c. Contorno, direcionalidade e reverberação}

À medida em que os sons expandem sua percepção equivale à dimensão dos desejo".

Gustave Flaubert

Para a performance do contador de histórias, esses três últimos parâmetros apontados por Lignelli estão relacionados ao espaço em que são produzidos, isto é, dizem respeito à uma intenção de atingir os ouvintes e uma finalidade de se fazer 
ouvir sem esforço, para que o conto possa fluir. Entender o comportamento do som em sua produção e percurso (do contador ao ouvinte), atentando para a função de cada parâmetro sonoro, oferece ao contador controle de sua produção vocal, para enriquecimento de sua narração. Essa é a direção da técnica a ser construída. Segundo Lignelli, o que dá o entendimento claro era o que eu chamava, anteriormente, de forma da palavra, imaginar o seu contorno (embora eu tenha imaginado visualmente):

\begin{abstract}
Considera-se, então, o contorno como um parâmetro do som, uma vez que ele pode ser detectado na música, na fala e em qualquer outro tipo de produção sonora. A conscientização dos contornos que tendemos a produzir vocalmente e a sua modificação proposital podem ampliar nossa efetividade discursiva nos mais diversos ambientes educacionais, artísticos e cotidianos (ibidem, p. 210).
\end{abstract}

Esse parâmetro está mais relacionado à entonação e, por isso, escolho discuti-lo como característica da fala, uma vez que 'entonação' foi apontada, em minhas oficinas e cursos para contadores de histórias, como um dos recursos valiosos para o narrador, entre os cinco mais importantes. O contorno da voz é identificado pela frequência, em seus movimentos de vibração, mas, também, pela intensidade, timbre e ritmo. O que importa no momento é o que acontece a partir do instante da produção sonora do contador, até o momento em que este som desaparece no espaço ou no ouvido do ouvinte, isto é, chega ao fim, no espaço em questão.

Se o som é constituído de ondas em movimento, cada local em que vai acontecer uma contação de histórias merece atenção do contador, antes de iniciar sua narração, pois os tamanhos e formatos dos locais são variados. Observar de que forma o som se propaga no ambiente e como ele favorece a audição dos ouvintes é possível na identificação dos parâmetros sonoros, pensando na projeção acústica.

Mais uma vez, na contribuição de Lignelli, percebo que "a direcionalidade diz respeito à localização espacial de onde o som é produzido ou reproduzido" (2011, p. 211), auxiliando na percepção do contador, em relação à sua posição no espaço. Pensar na direção do som inclui a verificação da direção do vento, em áreas abertas, o retorno acústico do local (que pode impedir a audição) e o comportamento do som, quanto à sua reverberação. 
De acordo com o autor estudado, uma onda de som é alterada pelas características do espaço, influenciada por propriedades dos materiais do ambiente e de sua temperatura. "A reverberação, então, refere-se à percepção da distância entre a fonte sonora e o receptor, associada ao tamanho e característica do espaço no qual o som é executado" (LIGNELLI, 2011, p. 215), em outras palavras, o tempo que o som leva para ser absorvido pelo ambiente. $O$ autor explica que isto acontece por que a onda repetida é mais fraca que a anterior, por isso, o som vai diminuindo, aos poucos.

Em minha experiência e observação, o contador deve estar atento aos finais de palavras, mais especificamente, em como o som destas são projetados no espaço. Esperar até que se apague o último dos ecos, quando houver muita reverberação no local. A voz grave é melhor para circular em todo o ambiente, pois no agudo, a frequência é maior, causando maior reverberação e mistura entre os sons.

Ambientes muito cheios de vidros e paredes lisas ou locais muito abertos têm condições acústicas precárias, dificultando a audição do ouvinte, pelas razões expostas. Nesses ambientes, o som fica rebatendo de uma parede para a outra, em um eco sem fim. Como consequência desse vai e vem, os sons se embaralham e fica difícil distinguir direito as palavras e frases, interferindo negativamente na narração.

Em locais como pátio de escola, ou salões de festa com muitos vidros, uma forma de amenizar o problema é mudar a textura do teto, vãos e paredes do ambiente. Hoje, existem especialistas que estudam até a acústica das plantas, tamanha exigência de usos diversos. Segundo Lignelli, "os corpos humanos assimilam dois terços do som que chega até eles" (2011, p. 215). Mas, como forma provisória, em escolas, por exemplo, costumo amenizar o problema com coberturas no teto e nas paredes com tecidos que absorvem o som e melhoram a acústica do ambiente. Sem a possibilidade de aliviar os problemas de acústica, minha opção é não contar histórias para grandes públicos.

\subsubsection{Características da palavra}


Junto à discussão dos parâmetros do som, César Lignelli trata as questões que envolvem a acústica da cena, considerando todo seu entorno. "A dimensão acústica constitui-se numa ampla rede de relações entre as esferas da palavra, da música, do entorno acústico e do desenho de toda a performance" (LIGNELLI, 2011, p. 223). A identificação dessa rede de relações favorece as escolhas do contador, que emprega os parâmetros do som e a dimensão acústica na elaboração de sua narração.

Em razão de a palavra ser a matéria prima do contador de histórias, já apresentada anteriormente, priorizo o conhecimento de sua produção sonora como foco para construções de técnicas narrativas, investigando seus recursos. Para este fim, apresento minhas observações pessoais sobre a articulação, o sotaque, a entonação e os sons onomatopaicos, como recursos a serem observados mais de perto.

\section{a. Articulação}

Para que o entendimento das palavras que compõem uma história tenha maior qualidade, independente de características pessoais, sua articulação é um fundamento. Estudos e práticas na área do canto e da vocalidade ${ }^{140}$ mostram que, ampliando a movimentação da boca, a pronúncia pode melhorar bastante. A articulação clara das palavras é responsável por sua compreensão, sendo essa articulação compreendida como o movimento justo e necessário para a produção de som de determinada sílaba ou vocábulo. De resto, todos os parâmetros vocais expostos, anteriormente, estão envolvidos nesta produção sonora, fornecendo indicadores para as variações vocais desejadas: abertura de boca, posicionamento de língua, utilização da caixa de ressonância (na face e no peito), quantidade de ar envolvido no movimento sonoro, uso de timbres com variações de posicionamento de músculos envolvidos, percepção da pronúncia rítmica da cada palavra.

Ao longo de minha experiência, a observação me mostrou que quando estudamos um texto em voz alta, mais o conhecemos. Pode acontecer, por exemplo, de encontrarmos cacofonias, que são encontros de vocábulos que produzem outro significado, por exemplo: "uma mão", que pode ser confundido com a fruta "um

\footnotetext{
${ }^{140}$ Sílvia Davini (2007); César Lignelli (2011); Terezinha Zaratin (2010); Ângela Finardi (2014).
} 
mamão", quando pronunciado na oralidade. Neste caso, o contador experiente altera a ordem das palavras, eliminando o efeito da cacofonia, no exemplo: "uma das mãos”. Na narração de uma lenda indígena, de meu repertório, falo sobre o casamento de Potyra e Itajibá. Quando falado em minha região, o encontro vocálico "e" e "i" provocam o hiato ii, sendo solucionado apenas com a alteração da ordem dos nomes: Itajibá e Potyra, conservando a beleza literária do conto. Isto vai variar entre as regiões, em razão dos sotaques diferentes nas falas, mas, também, na articulação clara e pausada das palavras. A atenção tem o foco de evitar duplos sentidos que desviam o entendimento da história, por tornar, às vezes, uma palavra incompreensível. A cacofonia também pode provocar irritações ou ironias nos ouvintes, desviando a emoção do conto.

Uma das características básicas do contador de histórias é a segurança com que compartilha com seu público a sua história (a que ele escolheu), articulando as palavras de forma clara, com contornos definidos. "Tropeçar nas palavras, gaguejar, não prestar atenção no que está falando; isto acontece quando o pensamento vai muito mais rápido que a fala e cria um abismo entre o sentir e o dizer" (SISTO, $2012 a$, p. 45). Ou, quando o contador não acredita em suas palavras como lembranças incorporadas, tendo como resultado uma recitação mecânica desprovida de sentido estético, que pouco afeta seu público.

Um dos exercícios mais citados como divertido e eficiente, durante as oficinas, é o trava língua, utilizado para melhorar a articulação das palavras. Mexendo com muitos músculos da face e com a língua, em todas as direções e posições, o narrador oral vai descobrindo novos sons e novas formas de pronúncias para encaixar em sua performance narrativa. O objetivo é, também, ir fortalecendo a musculatura do ator/contador, para que ele seja capaz de chegar ao fim da história com a mesma qualidade do início.

As indicações de cuidados e higienização da garganta, antes e depois do uso da voz, fazem parte do conhecimento e responsabilidade de cada narrador. Por isso, o aquecimento prévio, iniciando pelo alongamento dos músculos e articulações do pescoço e pronunciando, de maneira até exagerada, cada sílaba proferida, são importantes e podem melhorar a performance do narrador. A amplitude na execução da articulação, durante os exercícios, provoca um alongamento, fortalecendo a musculatura e facilitando a fala, consequentemente, sua maior compreensão. Este é um movimento corporal importante na descoberta do treinamento do contador. 
Além da articulação, isto é, de como as palavras ao serem pronunciadas exigem maior ou menor tensão, também o sotaque e a entonação estão envolvidos na compreensão da palavra do contador.

\section{b. Sotaque}

Sotaque é a maneira particular de cada povo articular e pronunciar sua fala. Segundo o dicionário Houaiss (2001, p. 1326), "é uma variante em qualquer grupo linguístico, podendo se caracterizar por alteração de ritmo, entonação, ênfase ou distinção fonêmica. Pronúncia imperfeita de idioma falado por estrangeiro". Essas variantes e pronúncias diferentes (mas não imperfeitas) são ricas fontes de recursos vocais para o narrador.

Em nosso país, cada região tem até mais de um sotaque. A diferença é tanta que chega a ter mais de um sotaque em um mesmo Estado, ou em uma mesma cidade, com a presença de imigrantes, oriundos de muitos lugares diferentes, como é o exemplo de Brasília. Essas diferenças advêm da cultura do povo de cada lugar, de como eles foram entrando em contato e se relacionando: brancos, índios, negros, portugueses, holandeses, japoneses, latino-americanos, espanhóis, etc., e das variações linguísticas que são dinâmicas como em qualquer cultura.

Cada povo deixa de si um traço qualquer. Uma palavra, uma forma de pronunciar determinada sílaba, um trejeito com a boca ou com a garganta, garantindo uma pronúncia particular, caracterizando aquele determinado jeito de falar (sotaque), identificando sua origem. Às vezes, um sotaque é tão carregado e tão diferente de outro que chega a causar estranheza, provocando consequências diversas, como o riso, por exemplo, ou o não entendimento. As misturas de sotaques podem confundir ou enriquecer a narração, dependendo do uso e da habilidade do contador. Assim, não se pretende estabelecer certos e errados à forma de conhecer e treinar cada sotaque escolhido. Como possibilidade de recurso, na preparação de uma história a ser contada, é experimentado e analisado pelo contador, em sua preparação.

Em uma história oral, sobretudo, de sua própria região, o contador será mais fiel, preservando o seu sotaque. Imitar sotaque de outras regiões que não a sua, exige do contador muita observação, capacidade de imitação e segurança. Há que se tomar cuidados para não ficar forçado e desagradável! O melhor treinamento é o 
convívio, a imersão no local, pois de um dado sotaque também fazem parte os trejeitos e cacoetes, a maneira de ser, agir e pensar, enfim, todo o universo cultural do povo daquele local.

Cada região brasileira tem uma peculiaridade em sua forma de falar. Entretanto, Brasília é uma cidade especialmente rica para se conhecer sotaques de várias regiões e suas infinitas misturas. Não existe um padrão da cidade, e sim, uma grande mistura de todas as partes do Brasil, que conservam seus sotaques, modificando-os na interação com outros e mostrando o movimento da linguagem, como verificado no estudo da sociolinguística. Nesta cidade, diferente das outras do País, é possível conhecer muitas variações da língua portuguesa brasileira, aprender vários sotaques, perceber influências e misturas sem, contudo, querer identificar origens e purezas dessa ou daquela região. Pelo contrário, o sentido de explorar esse tema é enriquecer o vocabulário do contador. Identificar os sotaques exercita a percepção auditiva e a sonoridade na entonação de cada fala.

\section{c. A entonação produz significados}

O entendimento de uma história narrada é constituído, sobretudo, pela entonação que o contador coloca em suas palavras, enquanto a narra. Essa entonação, a princípio, é fornecida pelas pontuações do texto, e entendimento do contador em sua própria interpretação. Entretanto, os estudos de Lignelli apontam para o contorno, como um parâmetro associado a todos os outros, que define a entonação das palavras.

\footnotetext{
Na palavra em performance o que é designado aqui como contorno pode ser historicamente associado a entoação ou entonação que é definida comumente com à modulação na voz de quem fala ou recita. No entanto, a entoação não se limita ao movimento das frequências, mas dos parâmetros como um todo (intensidade, timbre, ritmo). Sua importância na fala está diretamente relacionada a precisão e ao efeito do sentido proposto pelo performer (LIGNELLI, 2011, p. 206).
}

Descobrir as entonações de um texto exige estudar o texto, em voz alta. O narrador refaz a pontuação, à sua maneira, imprimindo ritmos, intensidades e outros parâmetros do som, significando a história. Cada narrador, neste processo, encontra seu modo de registrar as formas e contornos que vai elaborando em sua narração. Essas anotações são como uma partitura, anotações particulares que tem a 
intenção de auxiliar o contador na memorização de seus estudos, decisões e memórias futuras. Não há regras específicas para essa anotação, alguns alunos, em minhas oficinas, usavam símbolos, sinais, cores, desenhos com destaques, seguindo a orientação de um registro que possa ser guardado e retomado, posteriormente. Outros preferem usar o gravador, reconstruindo a entonação, durante 0 estudo.

Mas existe a diferença da palavra falada e da palavra escrita, que não se resolve na linguagem escrita, e, sim, em sua experiência prática na oralidade. Sabemos que uma simples vírgula pode, em lugares alternados de uma frase, mudar totalmente o seu sentido: _ Não gostei. _ Não, gostei!

Alterando os parâmetros vocais consegue-se uma voz mais triste, mais alegre, com surpresa ou tímida, por exemplo. Dependendo do que se tem como objetivo, emprega-se uma determinada entonação para dar significado adequado a cada expressão do texto. O grande exercício do contador está na descoberta das entonações de cada palavra e cada frase da narrativa, para que seus significados possam ser revelados, povoando o imaginário dos ouvintes.

Concordo com a observação de Shedlock, que: "O excesso de ênfase é a ruína de toda a narração de histórias, pois destrói a delicadeza, e toda a performance acaba sugerindo uma luta em busca da transmissão da mensagem" (2004, p. 28). Talvez a entonação seja um dos maiores segredos para a eficiência de uma narração, pois um mesmo texto pode ganhar vários significados, dependendo da maneira que o entoamos. O exagero nas entonações atrai estereótipos, que quando utilizados com excesso podem ser cansativos e enfadonhos. Tem a ver com a descoberta da voz interna do narrador oral em sua comunicação com o ouvinte.

Segundo Estrella Ortiz "as histórias são feitas para soar e, ainda que não sejam em verso, têm a música das palavras. Cada conto é como uma canção" (2004, p. 105). Ainda que seja na palavra falada, sua forma de entoar pode ser considerada como canção, do ponto de vista da organização dos sons para a produção do sentido. Na explicação de Regina Machado:

A experiência estética da escuta depende da cadência do narrador. O ritmo da narração é fundamental na forma de contar. O tom monocórdio da leitura ou da fala oral distancia a audiência da história, não permite que as pessoas "vejam", a história (2004a., p. 71). 
Ainda que a autora não compare a entonação com a música explicita, sua necessidade de cadência e ritmo que carregam em seus conceitos, as possibilidades de organização melódica. Encaro a entonação de uma história como música para meus ouvidos, procurando variações que sustentem o mistério, o encantamento e o envolvimento do ouvinte. Mesmo que não seja possível um modelo de entonação fixo, muitos autores, a exemplo de Regina Machado, Gislaine Matos, Sérgio Bello e outros, indicam uma atenção especial aos inícios e finais de histórias, lembrando que são portas de entrada e saída do mundo mágico. Deve soar como convite, nunca como imposição para a audiência, e finalizar com a importância de cada conto, no seu tempo, do seu jeito improvisado ou ensaiado!

\section{d. Sons onomatopaicos}

Plin!... pausa.

Pliin!!...nova pausa.

Pliiin!!!... silêncio quase absoluto,

À espera do Era uma vez...

Pode ser o som de um sino, de uma campainha, ou pode ser um som diferente dos sons usuais, produzidos de boca ou de corpo, com tamanha estranheza, que desperte a curiosidade dos passantes, transformando-os em ouvintes. É assim que gosto de chegar em uma plateia infantil, em uma escola, por exemplo. Os sons diferentes (tanto as onomatopeias quanto os sons de instrumentos musicais) parecem atrair os ouvintes, que acabam sendo capturados pelo fio da narrativa.

Segundo o dicionário Aurélio (1975, p. 999), onomatopéia significa: "palavra cuja pronúncia imita o som natural da coisa significada (murmúrio, sussurro, cicio, chiado, mugir, pum, reco-reco, tique taque)". Pensar sobre o que poderia ser considerado como "som natural" é complexo, uma vez que estamos lidando com uma multiplicidade de contextos, advindos dos textos das histórias. Na experiência do contador de histórias Sílvio Costta, onomatopeia é definida como: "termo produzido em virtude da reprodução de um som associado a ruídos ou vozes de animais" (2008, p. 77). Segundo o autor, alguns desses sons já são padronizados, inclusive, sendo entendidos em mais de uma língua. Percebo que são os sons que 
se aproximam mais de ações materiais, neste caso, mais distante da linguagem oral, que exige conhecimento e domínio de seu contexto.

Esse tipo de vocábulo ou som chama muito a atenção, sobretudo, das crianças menores, imprimindo um colorido especial ao texto. É uma forma de contar que atrai, sobretudo, a plateia infantil ou juvenil, pois, além de aproximar o público da veracidade dos fatos, com os ruídos, movimenta a narrativa em seu ritmo, variando a intensidade, timbre e volume de emissão da voz.

Com base nos estudos de Havelock, Busatto lembra que : "língua falada é uma trilha sonora, repleta de sons linguísticos que evocam situações, cenas, estados de espírito, saudações e que as onomatopeias são recursos mnemônicos que controlam a encantação dos versos" (2006, p. 64). Sugerindo ser este encantamento o "feitiço verbal" envolvido na narração das histórias.

As crianças das primeiras idades adoram se comunicar utilizando os sons onomatopaicos em suas conversas, assim como, também, gostam de ouvir com empolgação quando uma narração é cheia de sons misturados às palavras. A escolha do uso de sons onomatopeicos em uma narração de histórias é determinada pela prática do contador, que pode considerar a audiência infantil como a melhor resposta sobre a eficiência ou não de seus usos.

A produção vocal é considerada como movimento corporal inerente ao ato de contar uma história, mas não é o único movimento produzido pelo corpo do contador. Junto ao gesto oral, acompanha a expressão de todo o corpo, desde a cabeça até os pés, a postura e movimentos do contador estão envolvidos em uma mesma ação.

\subsection{Gestualidade}

Ouvir é ver aquilo que se fala; falar é desenhar imagens visuais.

Depois de concordar que os recursos vocais emanam de um corpo, são o próprio corpo do contador, vem a dúvida, talvez, mais repercutida nas oficinas: contar em pé ou sentado? O que fazer com as mãos? Como construir os gestos e 
uma infinidade de dúvidas, antes mesmo da escolha da história. A experiência mostra que os problemas vão surgindo, na medida em que a preparação vai explorando campos desconhecidos, da linguagem corporal.

Etchebarne (1991) sugere contar sempre em postura sentada, comentado em Andrade (2012). Não que isto seja uma regra, há que se considerar que a autora (doutora em Filosofia e Letras) defendeu sua tese em 1950, na Argentina: "El arte de narrar: oficio olvidado", tema bastante ousado para a época, o foco na narrativa, nos significados e poder de envolvimento por meio das palavras.

Catherine Zarcate é uma contadora tradicional francesa (do início da chamada renovação do conto, como já exposto no capítulo 1) que consegue uma profundidade em sua narração, envolvendo o ouvinte em seus mínimos gestos, de tal maneira que me impressionou, por sua posição sempre sentada e nada monótona, apesar de raramente movimentar um dos braços para que os dedos alcancem um instrumento de corda, com características orientais. Fora esse movimento visível, somente seu rosto se mexia, porém, a capacidade de suscitar imagens e envolver os ouvintes era contagioso. Tal afirmação se justifica pelos comentários que ouvi, logo após uma sessão de histórias apresentada pela contadora, no evento "Boca do Céu", em 2012. Chamou minha atenção a identificação da percepção de muitos ouvintes, que comentavam a força de sua palavra e de sua expressão. $E$ isto, até para quem não entendia a língua francesa (havia tradução simultânea - individual).

Concordando com Busatto, "uma contação de histórias pode se dar de uma forma mínima, essencial, contando apenas com a palavra anunciada, sem movimento corporal ilustrativo, sem o mexer de uma sobrancelha" (2006, p. 70). Era exatamente assim que me sentia frente à performance de Zarcate, a que relacionei, de imediato, à palavra força de Zumthor: "O verbo se expande no mundo, que por seu meio foi criado e ao qual dá vida" (1993, p. 75). A palavra se torna o sentido e gesto, ao mesmo tempo.

Como diz Busatto: "Se contar em pé nos permite maior flexibilidade, por outro lado também nos expõe mais. Precisamos estar conscientes deste corpo que se locomove, do seu peso e leveza" (2012, p. 70). E manter a importância no texto.

Considero que cada história e cada espaço pedem posturas diferentes. Já contei histórias de pé, com alguns movimentos (mais preparada para um palco), em uma roda de piquenique, sem prejuízo algum para a história, ou para o evento. Em 
outro exemplo, uma história que tenho hábito de contar sentada, quando experimentei contar de pé, me adequando melhor ao local, me surpreendi em um terrível andar para lá e para cá, que me causou uma terrível impressão de um tom professoral, muito chato. Poucas vezes fiquei insatisfeita com minha performance, como nesse dia.

O contador cria imagens no ar, materializando o verbo e transformando-se, ele próprio, nesta matéria fluida que é a palavra. Ele me empresta o corpo, sua voz, seus afetos ao texto que ele narra, e o texto deixa de ser signo para se tornar significado (BUSATTO, 2006, p. 79).

Se esse corpo fica andando de um lado para outro, sem um significado específico para a compreensão da história, com gestos imprecisos e incompletos, confunde e rouba a atenção do ouvinte. Definir os gestos para uma história pode não ser fácil, no início, pela falta de hábito. Depois que o contador conhece seu próprio repertório, os gestos saltam para dentro da história. Nos exercícios das oficinas e cursos, cada aluno criava três gestos, um para cada ponto da história, explorando-os durante a narração. Impressionou-me a semelhança de minha experiência com o relato de Cléo Busatto:

Professores que traziam escrito no corpo um registro de anos de uma prática presa à cadeira, e que naquele exato momento se movimentavam graciosos, de lá pra cá, deixando escapar dos lábios os personagens, as situações e os espaços mais inusitados (2012, p. 12).

O mais importante era a sensação de conquista, no final de cada encontro. Os gestos trabalhados nas histórias raramente eram aproveitados na íntegra. Ou se modificavam, ou eram, simplesmente, descartados na hora da contação. Mas, com certeza, a experiência se acumula em um repertório gestual que pode, em algum momento, ser aproveitado, principalmente quando sua plasticidade agrada. Assim, contar sentado ou de pé, com ou sem movimentos, depende do contador, do texto e do ouvinte.

\subsubsection{Gestos e movimentos na ação de contar}

Os movimentos e gestos de uma história, quando estudados e pensados no momento da preparação do conto, ajudam a evitar o exagero, a inexpressividade ou 
confusão de sinais. Para o efeito deste estudo, assumo que o gesto é qualquer movimento que tenha um significado específico. Assim, todo gesto contém movimentos, mas nem todo movimento pode ser considerado como gesto, por exemplo, ou movimentos corporais vitais e a expressão natural de cada corpo em sua postura.

No estudo de gestos e movimentos, o corpo de cada contador age por inteiro, de maneira própria, no sentido de que 'movimentos gestuais', que complementam o significado das palavras, pertencem à cada indivíduo, sendo compreendidos coletivamente. "Nas performances da oralidade, o gesto não é apenas uma representação mimética de um aparato simbólico, veiculado pela performance, mas institui e instaura a própria performance" (MARTINS, 2003, p. 70). Ou seja, o gesto é participante ou realizador e, não, parte da performance. Assim, completa Celso Sisto:

Os gestos e as vozes devem ser selecionados e utilizados como Houaiss continuadores da palavra, não como recursos estanques, enxertados na história para garantir o brilho. A palavra por sua própria força, demanda gestos e expressões que surgem de forma orgânica (2012a, p. 35).

Para conseguir deixar o gesto nascer de forma orgânica é preciso aprender a se ouvir primeiro, a entender seu próprio corpo, conhecer os recursos de sua linguagem e se libertar. Contar, muitas vezes, é o que faz amadurecer o conto, conviver com ele. Essa necessidade de testar, escolher e ensaiar gestos, inúmeras vezes, até atingir o ponto desejado para enriquecer a narração, faz parte do contador que faz opção pela pesquisa artística.

Cada história oferece seus próprios subsídios para o emprego de recursos para a narração, em alguns textos, o enredo quase não sugere movimentação, contrapondo-se a outros que chegam a interagir com a plateia, movimentando todos os corpos presentes. O movimento do contador se faz acompanhar do ouvinte que entra no mundo da história, tornando-o real para ele, naquele instante da narração, na explicação de Busatto:

No instante em que o contador de histórias movimenta-se no espaço criando cenários, personagens e ações, com gestos diminutos ou ampliados, ele não está apenas conduzindo o nosso olhar para o que ele está gerando, mas também provocando a ilusão de que aquilo de fato existe. Mas, para o imaginário, essa ilusão é real (2006, p. 64). 
O que a autora sugere é que o contador, ao ser acompanhado pela plateia, de perto, nos mínimos detalhes, consegue gerar a ilusão do imaginário, e, percebo que essa possibilidade é despertada pelos recursos de narração da linguagem corporal. Embora o gesto seja valioso para atrair atenção dos ouvintes, a experiência mostra que seu exagero mais afasta do que aproxima o ouvinte. Celso Sisto fala em economia de gestos:

O texto oral caminha pela vereda da economia, da síntese. É significar muito com o mínimo e banir o supérfluo. E gesto também é texto, assim como movimento, olhares, tons de voz. E não dá para voltar atrás, para interromper, para repetir, como se faz com o texto escrito (2004, p. 86).

Por isso é que ensaio antes, pois se torna possível apagar um gesto, modificar uma entonação, sintetizar melhor determinado ponto da fala, enfim, fazer os ajustes necessários para que a narração funcione. Independentemente do tipo de deslocamento que cada história suscita, Celso Sisto (2012a) trabalha com três qualidades de gestos, como forma de explorar a interação na narrativa. São eles: ilustrativos, enfáticos e sintéticos.

No meu entendimento, com base nos estudos desse autor e de minha prática, posso concluir que os gestos ilustrativos demonstram e/ou reforçam uma palavra (cabendo o uso de clichês do cotidiano ou gestos mais elaborados como a mímica); enfáticos, são gestos fortes com o intuito de chamar a atenção, especialmente para um determinado trecho, mais importante da história; sintéticos, representados pela expressão individual, mostram-se na manifestação plástica do gesto/movimento, é o enfeite, que não precisa ficar exagerado (afetado), depende de cada forma pessoal de interpretação e do que cada texto oferece.

Para alguns contadores é importante pensar, elaborar e ensaiar os gestos, antes da apresentação da história. A confusão mais comum em um gesto improvisado é quando ele é lembrado, em uma parte da história e esquecido, em outra, quando não poderia ser esquecido, pois seria continuidade daquela. Neste caso, é colocado em risco o entendimento da história.

O gesto pode nascer do improviso. É contando a sua história que o contador vai ficando cada vez mais espontâneo, deixando fluir a gestualidade, de dentro para fora. Mas o corpo tem de permitir essa liberdade. No processo de descoberta de gestos significativos, apenas alguns são escolhidos e começam a ser incorporados na narração. Cada um acaba encontrando sua melhor forma, mas defendo que o 
ensaio pode melhorar muito a qualidade da linguagem corporal. Pelo menos para limpar gestos indesejáveis, como: passar a mão no cabelo, arrumar a roupa, etc., quando não fazem parte da história.

A linguagem corporal e gestual de cada pessoa vai se estruturando e se modificando, de acordo com a maneira com que cada um amplia suas pesquisas individuais. A gestualidade do contador oferece recursos do olhar; das expressões do corpo e da face, em suas expressões próprias; para a construção de personagens na narração da história; no uso do espaço pelo contador; no uso de figurinos e objetos, pelos contadores.

\subsubsection{Olhar: lugar de encontros}

O olhar do contador de histórias é múltiplo, pois, ao mesmo tempo, é interior, voltado para o texto (ou o conto conhecido) e, exterior, atento a tudo o que está em volta, procurando não deixar que nada atrapalhe o fio da narrativa.

Essa atenção para o exterior, além de evitar qualquer interrupção, tem, também, o sentido de querer incluir o que acontece na plateia durante a história, para dar mais veracidade à narrativa. É a provocação de interações entre contador e ouvinte, às vezes, envolvendo todo o público. Por exemplo, quando o contador vai descrever um personagem, pode colocar algumas características visíveis de alguém da plateia, como detalhe do cabelo ou da roupa, incorporando o ouvinte na história. Nas histórias literárias, essa interferência é mais difícil, mas, quando possível, funciona, como demonstrado no exemplo do cheiro de pão de queijo, na 'Verdadeira História dos Três Porquinhos', no capítulo anterior.

O outro olhar é interior, para dentro do contador, para sua própria emoção, para o texto já internalizado e para as imagens que possam fluir na narração. Todas essas formas de olhar consistem na aproximação do contador com o seu público. Quando um olhar encontra outro, cuja emoção é a mesma, eles se tornam cúmplices, comemorando por meio desse olhar o compartilhar de um mesmo entendimento, ou sentimento dos significados atribuídos àquelas palavras. Por isso, quem conta, conta com alguém, e nunca, sozinho!

O olhar é alimentado pela expectativa do ouvinte. Só a experiência é capaz de mostrar, por meio do olhar do espectador, quando uma história está ficando 
longa, ou cansativa. O olhar funciona como um termômetro para o narrador oral experiente.

Do ponto de vista do contador, noto que alguns olhares podem prejudicar uma narração, por exemplo, olhar para cima pode ser sinal de que o contador está procurando uma parte que falta do texto, ou seja, falha na memória. Claro que isso também pode acontecer propositadamente, em casos muito bem marcados na história, por algum motivo intencional, mas o ouvinte sabe muito bem distinguir quando é proposital ou esquecimento. É fácil perceber quando um olhar fica perdido procurando uma parte do texto na memória ou quando um olhar perdido faz parte da história, isto é, quando é parte da linguagem corporal do contador, criado ao preparar a história.

O outro ponto é evitar contar para uma única pessoa. Todos os presentes merecem a atenção do narrador. Confesso ficar extremamente incomodada quando alunos em oficinas e cursos, contam fixando o olho em mim, ou em algum colega em que tenham segurança, parece que o conto fica preso entre eles. Contar é também compartilhar olhares.

\subsubsection{Expressão: o esclarecimento do corpo}

O entendimento do corpo em sua expressão, tanto pela face quanto pelas outras partes do corpo, é a busca do contador. Cada expressão revela significados, à sua maneira, tendo correlação com determinados aspectos culturais em que o narrador oral está inserido. A compreensão desse corpo em sua totalidade, com suas expressões, por meio das falas, gestos e movimentos é um dos fundamentos da linguagem corporal do narrador.

A expressão do rosto do narrador oral, assim como a de seu corpo todo, acompanha o enredo da história que ele está narrando. É muito estranho e distante, quando um contador de histórias mantém um rosto neutro, enquanto a narrativa suscita outras reações. A expressão facial pode ser entendida como uma característica do gesto. Um mesmo gesto de raiva, por exemplo, pode ter uma expressão triste ou alegre que o acompanhe. Todo gesto é, por si só, expressivo e, se for produzido organicamente, de dentro para fora, terá mais coerência com o que foi dito. Quando o contador fica procurando uma expressão que se encaixe em 
determinado ponto, ou seja, de fora para dentro, raramente funciona, porque fica superficial.

Aprender como as partes do nosso corpo, sobretudo o rosto, se expressam, exige observação interna e externa. Cada movimento ou gesto de braços, pernas, mãos, olhares, interage com o ouvinte, criando significados que complementam as palavras e as pausas entre elas. Aprendemos com a experiência do contar e do ouvir a fazer essas leituras corporais.

Nesse sentido, aqueles contadores que escolhem trabalhar em grupo, podem ter a generosidade dos comentários dos colegas, no intuito de que o ouvinte é o mais apto para avaliar uma performance. Este é, também, um aspecto do trabalho solidário dos contadores de histórias.

Uma experiência que tem sido interessante em oficinas de contadores é observar a reação das pessoas, com os jogos de manifestação das emoções, sobretudo, quando se deparam com cartões que revelam, por meio de desenho, as expressões do rosto. Descrição:

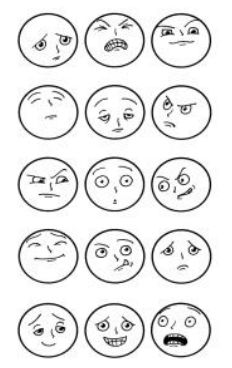

(sem os cartões), os alunos são organizados em duas fileiras, uma de frente para outra. Eu digo uma emoção para uma das fileiras, por mantendo a concentração. É difícil ficar triste enquanto tem alguém olhando para você cheio de alegria, pois uma das regras do jogo é manter o olhar, o máximo possível, no companheiro da frente.

Nesta mesma dinâmica, a variação que os alunos mais gostam é quando são distribuídos os cartões: para tentar imitar a expressão, para identificar que expressão é aquela; para moldar uma expressão no colega da frente e ver se dá certo, ou ainda, uma infinidade de variações que vão surgindo, de acordo com o 
comportamento dos alunos. Essas fichas ${ }^{141}$ são simples e podem ser encontradas no exemplo abaixo, em pesquisa na internet.

Estes exercícios mostram os movimentos internos e externos das expressões, considerando como interno o desejo e a intenção e, como fator externo, as contrações e relaxamentos da musculatura da face, na realização de determinada expressão. Por exemplo, o sorriso, alegria, felicidade ou emoções semelhantes são demonstrados fisicamente, levantando os cantos da boca, para esboçar um sorriso. Entretanto, para que este sorriso seja expressivo, um componente interno é acionado, na intenção da manifestação dessa emoção, reivindicada, também, por Regina Machado (2004a.) como fundamento para uma narração. A consequência pode ser o brilho nos olhos, que acompanha as expressões felizes.

\subsubsection{Personagem: lugar da alteridade}

O primeiro personagem a ser construído, que fará parte de todas as histórias, é o narrador oral, que poderá ser pensado em duas vertentes. Uma, em que o contador se descobre narrador, com base em suas próprias características, objetivos, estilos e estéticas e, assim, constrói um repertório que combine e responda aos anseios deste narrador, assumindo ele próprio a condição de narrador (como ocorre em minha experiência). Outro, quando o narrador é um personagem, desenvolvido para este fim, geralmente, inspirados em contadores da tradição oral (mas isto não é regra).

$\mathrm{Na}$ área do teatro é comum encontrarmos contadores que preferem escolher um personagem para narrar por eles. Já nas escolas são os próprios professores, com seus nomes cotidianos, que desenvolvem a arte de contar histórias. Eu tenho contado histórias como Ângela, tia, professora, amiga, atriz, artista. Em cada local, minha identidade tem se manifestado de forma diferente, embora quase sempre como Ângela. Certa vez, algumas integrantes do grupo Arco de Véia ${ }^{142}$ decidiram que as contadoras seriam mocinhas ingênuas da zona rural, e cada uma construiu

\footnotetext{
${ }^{141}$ As fichas que uso foram tiradas dos exemplos do livro: Você: um estudo objetivo do comportamento humano. Desmond Morris. Edição do Círculo do Livro, 1977.

${ }_{142}$ Grupo Arco da Véia faz parte da pesquisa cadastrada na Pró-Reitoria de Pesquisa e PósGraduação da UFG, desde 2002, intitulada: "Cultura e contadores de histórias: literatura, brincadeiras e jogos populares". Os integrantes são, na maioria, alunos da UFG, portanto, o grupo não é fixo, mudando seus integrantes a todo ano. Experiência relatada no capítulo três.
} 
sua personagem, com um nome e um figurino. Elas se sentiam mais espontâneas dentro da personagem que construíram e saíram pelo Campus Universitário, em diversas apresentações, às vezes improvisadas. Portanto, não precisa haver regras a serem obedecidas, cada contador deve escolher a forma que mais lhe é pertinente e o aproxime de seus objetivos, podendo, inclusive, variar essas formas.

Quanto à exploração de outros personagens, vai depender do que o texto oferece, ou pede. Uma narrativa mais simples, na perspectiva da contação, apresenta apenas a figura do narrador, é remetida ao passado, ou contada na primeira pessoa, e o tempo presente revela o narrador oral como próprio personagem. Nestes dois casos, não haverá necessidade de imprimir certas características para diferenciação dos personagens, o narrador é o único papel, do início ao fim da narração.

Outros textos associam falas e ações de diversos personagens, entremeadas às falas do narrador, aparecendo a oportunidade de designar alguma característica específica para o destaque de tal personagem. Estas características aparecem no timbre de voz (na voz estridente e rasgada da Velha), e/ou em uma característica física/gestual que será utilizada pelo contador, cada vez que aparecer este personagem na narração. Por exemplo, na história "O Macaco e a Velha", versão de Braguinha, da coleção Disquinho ${ }^{143}$, escolhi preservar o diálogo cantado entre o macaco e o boneco de piche, fazendo a diferença entre os personagens nos gestos. O macaco se identifica pela postura: coluna curvada à frente, pernas abertas em forma de arco e braços, também, um pouco arredondados, ao longo do corpo, com as mãos um pouco encurvadas para o lado de dentro do corpo. $O$ boneco se caracterizava por ficar balançando todo (se sacudindo), enquanto cantava respondendo. Esta história é uma das primeiras do meu repertório e eu a considero a mais rica na gestualidade e caracterização dos personagens, no meu repertório.

Para um contador iniciante, o texto mais fácil é aquele em que os personagens tenham falas isoladas, sem diálogo direto entre eles. Alguns alunos demonstram maiores dificuldades de uso do corpo na narração, produzindo movimentos pendulares, de vai e vem, quando dois personagens dialogam no

\footnotetext{
143“A Coleção Disquinho foi publicada pela Continental,em 1960 até meados dos anos 80, em compactos e discos LP de vinil coloridos. Foram 89 edições (incluindo 6 somente de cantigas) e cada disco trazia uma ou mais histórias cheias de músicas e interpretadas pelo Teatro Disquinho, com a narração de Sônia Barreto. As músicas eram compostas e adaptadas por João de Barro e orquestradas por Radamés Gnattali”. No site: https://www.youtube.com/playlist?list=PLBD47852D972158A4 Consultado em 18/09/2015.
} 
decorrer do texto. Nas narrativas mais simples, a fala de cada personagem é entrecortada pelo narrador, isso facilita a concentração e a diferenciação entre os falantes do texto.

Desde o início da experiência de um contador, já é possível imprimir características específicas aos personagens, fazendo uso de recursos de representação e de interpretação, durante a narração das histórias. Os personagens são pesquisados buscando características como: timbre de voz, modo de caminhar, trejeitos, sotaque, expressões corporais e faciais, alguma mania ou objeto que o acompanhe (imaginário ou real/concreto), emoção que o envolve, espontaneidade, respiração, ritmo e outros aspectos, que vão depender da criatividade do contador e do que o texto oferecer para ele.

Mas não é de uma vez que isso tudo acontece. O contador conhece o personagem aos poucos, "conversando" com ele e com o texto, ao mesmo tempo. $O$ livro de Michael Chekhov (2010), "Para o ator", pode ser uma grande fonte de pesquisa de como construir os personagens.

Considero o exercício de construção de personagens como um exercício de alteridade, entendida como o que pertence ao outro. Ao se colocar no lugar deste outro (o personagem do conto), o contador experimenta uma nova "identidade", convive com novos diálogos, consigo mesmo. Esse constante exercício de se colocar no lugar do outro pode trazer reflexões e transformações importantes no comportamento humano em relação às injustiças sociais.

A construção de personagens também informa e incentiva novos conhecimentos, por parte de quem o compõe. Lidar com essa diversidade exige diversificação de informações, que fazem parte da busca constante do contador.

\subsubsection{Espaço cênico do contador}

Considero como espaço cênico o lugar onde se posiciona o contador em relação às possibilidades de movimento, durante a narração de suas histórias, para determinado público. Alguns ambientes separam contador e público: palco e plateia. Outros ambientes são mais intimistas, aproximando os envolvidos, num maior aconchego. Já citei o exemplo do piquenique, anteriormente, que não separa o espaço entre contador e ouvinte, pois todos na roda são convidados às duas ações. 
O espaço cênico, em cada contexto que for realizado, se adequará à realidade do local: teatro de rua (praça, parque etc.), salões, escola (dentro e fora da sala de aula), teatro com palco italiano ou similar, teatro de arena, residência em que haja alguma festa, sarau e outros. "Pensar o espaço, o local dos espetáculos e associado a isto pensar a dramaturgia, o ator e suas relações com o espectador é também pensar o mundo" (HADDAD, 2005, p. 62). Cada situação pode oferecer, inclusive, possibilidades diferentes com as quais o contador terá que se adaptar, experimentando novos detalhes em seu modo de narrar. A interação com o espaço permite ao contador perceber o seu entorno e evitar interrupções, ou se aproveitar de detalhes a serem inseridos na narração. E, observar os parâmetros do som que interferem nesse espaço, usufruindo de seus conhecimentos em favor da história.

As experiências mostram que se o contador lida facilmente com o improviso, sua capacidade de adequação do espaço tende a ser maior.

\subsubsection{Objetos nas histórias}

A presença de objetos na narração de uma história, em minha experiência, foi construída aos poucos, nos cursos, oficinas e observações de espetáculos teatrais de bonecos e formas animadas, com pesquisas empíricas, com reflexões coletivas discutidas no grupo de pesquisa. Acredito que seu uso é sugerido pelo texto e pela criatividade do contador. Não importa se o objeto utilizado é real ou imaginário (apresentado pela mímica), tanto seu aparecimento em cena, quanto sua retirada devem fazer sentido e dar continuidade à narrativa, e, não, quebrá-la, desviando a atenção do ouvinte, às vezes impedindo a compreensão da história. Qualquer objeto levado para a cena é considerado como uma extensão do corpo do contador, necessitando de cuidados e treinos. Se o gesto nasce de dentro para fora, o objeto também é incorporado, de maneira a participar dos movimentos do contador na qualidade de gesto, capaz de produzir significados.

Em minha experiência, para marcar um objeto determinado no espaço, durante a narração de uma história, em um palco, por exemplo, olho para o chão procurando fazer uma relação entre o que está nele e as referências ao redor, do espaço cênico utilizado: o que está em frente e nos lados direito e esquerdo, enfim, conheço rapidamente o espaço, em torno do meu espaço, e me localizo nele. 
Procuro as primeiras orientações referentes ao meu corpo, estabelecendo relações com as construções arquitetônicas, que são externas e fixas e me servem de referência. Esquadrinho a possibilidade de uma marquinha qualquer - de preferência no chão - um risco, um buraquinho, o entroncamento de duas linhas, um elemento físico. Utilizo essa marca para lembrar em que ponto meu corpo estava, no momento em que me referi àquele objeto, e como o gesto foi definido, anteriormente, é fácil me colocar no mesmo posicionamento, remetendo o ouvinte àquela imagem anterior. Uso isto como técnica (construída a partir de uma necessidade prática), no poema de Cora Coralina, já citado, anteriormente, quando, no início, o 'bolo' "se guardava bem guardado, com cuidado, num armário alto, fechado, impossível". (CORALINA, 1997, p. 54) - momento em que faço um gesto sugerindo um armário no alto, à minha esquerda e em frente - ao final do poema, reaparece o bolo: "esperando a descida certa do bolo encerrado no armário alto" (ibidem, p. 56). Porém, meu posicionamento não é mais o mesmo e, se não houver a recuperação daquele local apontado, anteriormente, pode comprometer o entendimento do ouvinte. Vai depender muito da história, mas a marcação se tornará essencial naquelas que são muito movimentadas, para que não fiquem confusas.

Quanto ao uso de objetos reais ou concretos, construídos ou simplesmente, utilizados em narrações, é um campo riquíssimo a ser explorado. Neste sentido, a experiência orienta os iniciantes a escolherem apenas um acessório para fazer parte de suas primeiras experiências. Um mesmo objeto pode se transformar, exercendo vários papeis e funções, enriquecendo a narração de um conto. Tudo depende de pesquisa $^{144}$ e treinamento.

\subsubsection{Figurinos: ajudam ou atrapalham?}

Um ponto comum entre muitos contadores da atualidade, mais explícito em Fox e Girardello (2004) é que os assessórios utilizados em uma narração não podem ser mais importantes ou chamar mais atenção do que a própria história. Não importa que sejam espalhafatosos, barulhentos, grandes ou pequenos, desde que

\footnotetext{
${ }^{144}$ Para aprofundar conhecimento em teatro de formas animadas, consultar: Izabela Brochado (UnB); Ana Maria Amaral (Unicamp).
} 
auxiliem e não atrapalham a história. De resto, o que vale é o bom senso, como diz Margarida Baird:

\footnotetext{
tanto faz usar ou não uma roupa especial, criar um personagem contador, estar de cara limpa ou super maquiado, usar adereços como velas, pedras, pau-de-chuva, usar ou não usar cenário: o que vale é que a história esteja presente, que a plateia empreste seus ouvidos, que o coração da história pulse (BAIRD, 2004, p. 77).
}

Do meu ponto de vista, penso que cada espaço, evento ou história merecem ou acolhem um tipo de figurino. Depende do ambiente em que a história será contada, do objetivo do evento e dos contadores, não sendo possíveis regras ou conselhos. Gosto de ser surpreendida pela criatividade dos artistas! De vez em quando, aparece um enfeite forçado, parecendo tentar impor um clima que sua narração não consegue. Se a preparação da história for eficiente, o figurino pode completar sua estética, enfeitar ou incluir o contador no ambiente, mas não ser condição para sua narração.

No início do grupo Gwaya, mais precisamente, na apostila de contadores de histórias do grupo Morandubetá (nossos iniciadores), eram indicadas roupas lisas de cores claras. Nunca concordei com essa afirmativa, preferindo cores contrastantes, que revelam e iluminam o rosto do narrador, portanto, as pessoas mais claras ficam melhores com roupas mais escuras e o inverso também é verdadeiro, pessoas mais escuras mostram mais o rosto quando usam roupas de cores claras. Quanto ao estampado, concordo, assim como aceito que muitos assessórios interferem de forma negativa nos ouvintes, ocupando o olhar do ouvinte com formas e cores, às vezes, desviando-o da história.

\subsection{Ritmo}

A intenção dá a expressividade do ritmo na história!

Regina Machado

Se a intenção é responsável por imprimir ritmo em uma história, significa que há variações de possibilidades rítmicas em um só conto, pois cada um entende e 
significa as narrativas com base em suas próprias histórias e experiências. E, se a intenção pode mudar, significa que os ritmos sofrem alterações, de acordo com quem os imprime e para que fim. Concordo com a autora, não só pela afirmação da epígrafe, como também na declaração de que: "o ritmo não quer dizer apenas a pulsação, ou a repetição de batidas, mas muito mais do que isso" (MACHADO, 2004a., p. 41). Procurando o ritmo necessário para a narração de uma determinada história, descobrimos que cada contador possui seu próprio ritmo e, sem dúvida, essa interferência é direta nos resultados. Tive uma aluna no grupo de pesquisa (UFG), cuja fala era naturalmente muito rápida, precisando de muitos exercícios e repetições para que ela conseguisse um ritmo que combinasse, ao mesmo tempo, com ela, com o texto escolhido, e possível no entendimento para os ouvintes. A aluna venceu pela persistência, mostrando que quando se quer, é possível.

Cléo Busatto atribui esse mesmo sentido, no meu entender, explicando que: "ritmo e tempo estão dentro de nós; que ritmo é visão de mundo, é o caminho que nos leva ao tempo original e nos coloca em contato com o mito, que por sua vez, contém um tempo mítico, arquetípico” (2006, p. 72). A relação que faço entre o entendimento das autoras está, também, na busca interna proposta por Machado (2004a.), quando esta, ao preparar um conto, perguntando o que ele (o conto) tem para o contador, partindo para uma busca interna de trocas, para a construção do ritmo do conto. O que se busca durante uma narração é uma variação de cadências para evitar a monotonia, apontada por Regina Machado como:

Cadência é o ritmo, a respiração do contador de histórias, em consonância
com a "respiração" da história. Para poder acompanhar a cadência da
história, é necessária uma disposição interna do contador, para deixar-se
levar pela respiração, pela cadência, pelo fluxo da narrativa, modulando a
voz, o gesto e o olhar, de acordo com os diferentes "climas expressivos"
que o conto propõe. (...) A cadência é um movimento rítmico que envolve
rapidez, lentidão, pausa, voz alta, voz baixa. É o pulso, a respiração do
conto, tal como é experimentada pelo narrador. É essa experiência - estar
lá, dentro da história - que comanda o ritmo da voz de forma orgânica e
viva (2004a., p. 71/72).

Considerando a cadência como sinônimo de ritmo, concluo que a importância desta para a contação de histórias está mais relacionada com o autoconhecimento e a percepção de si mesmo em relação aos ouvintes. A escolha do ritmo determina e é determinado, ao mesmo tempo, pela respiração, clima e envolve algumas adequações, relacionadas à aprendizagem do novo contador. Por essa razão, o 
compreendo como um recurso da linguagem corporal, vinculado, diretamente, aos usos da voz e do corpo.

Recorrendo, novamente, à tese de Lignelli (2011), os muitos exemplos de compreensão de ritmos no mundo e nas pessoas levam à compreensão das interferências individuais no ritmo de cada um. "O andamento, a métrica, os acentos, o silêncio e a dinâmica são formadores do ritmo" (LIGNELLI, 2011, p. 169). Essas variações rítmicas acontecem dentro das palavras e das frases, durante toda a história, alterando a velocidade e, às vezes, a forma de dizer as palavras.

Achar a velocidade da narração de uma história significa perceber que tudo em volta pode interferir no ritmo do contador, da história, dos ouvintes e, ainda, do entorno, se o espaço assim o permitir. Nem muito devagar, a ponto de causar ansiedade ou sono no ouvinte, nem tão depressa, que dificulte o entendimento das palavras. Gosto de pensar na ideia de que o tempo da narrativa funciona quando acompanha o tempo dos ouvintes.

Às vezes, a história pede ao contador um exercício de trava línguas para ser aplicado na narração. Por exemplo, em um trecho do livro: O Grande Mentecapto (Fernando Sabino), a cena descrevia a inauguração da nave da igreja, com a orquestra da cidade. Um gambá preso no trombone foi lançado, indo cair direto nos peitos da mulher do prefeito, que segurou o bicho pelo rabo, lançando-o de volta. $O$ padre arrematou no peito, lembrando seus velhos tempos de futebol. E por aí, segue a narração, sugerindo uma velocidade de locutor de futebol na rádio. Contudo, no trecho seguinte, a velocidade da narrativa torna-se outra, quando acaba o jogo e entra em cena a orquestra que inaugurava a nave mãe da igreja. A primeira vez que contei essa história, precisei treinar muito a parte que considerei como trava-línguas - a narração do jogo de futebol. Contei poucas vezes essa história, que acabou ficando esquecida, e para recontá-la, sinto que teria de exercitá-la, novamente, em seu ritmo.

Um dos pontos que pode orientar um ritmo eficiente para a narração de uma história é o "feedback", dado pela atenção dos ouvintes, conquistado com a experiência do contador. Exercitar essa percepção exige prática de observação do ouvinte e, se possível, um diálogo de retorno ao contador em exercício, como acontece em muitas oficinas, inclusive nas minhas. $O$ ritmo é trabalhado, tanto na fala como nos movimentos corporais, sendo que um tem influência sobre o outro. Brinquedos cantados e cantigas com movimentos corporais auxiliam na descoberta 
do ritmo corporal de cada pessoa, comprovado tanto nas oficinas e cursos, como na percepção dos alunos que frequentaram nosso grupo de estudos. Consequentemente, contribui na formação de um bom repertório gestual e rítmico para uma narração. Concordando com Cléo Busatto:

\footnotetext{
O ritmo do contador revela suas condições reflexivas e a capacidade de conter os significados do conto. Seu corpo pulsa com os sentidos do narrado, pois ritmo é sentido, marcando uma batida harmônica, num galopar preciso, pontuado por sons e silêncio. Logo, cada imagem oferecida repercute no ouvinte, desce às profundezas de sua alma e lá estremece, ressoa, para voltar à superfície, na forma de suspiro, riso, choro, raiva, dor, alívio (2006, p. 73).
}

Por essas razões, o ritmo é o que mantém a atenção da plateia, do início ao fim de uma história. Se for linear, ou com poucas variações, a narração se tornará monótona e cansativa.

\subsubsection{A respiração na e da história}

A respiração é o elemento gerador do som e um dos elementos responsáveis pelo ritmo da narrativa. Se a respiração determina o ritmo de cada história, a tarefa do contador é escutar a respiração que a narrativa oferece. O contador passa a respirar junto com a história, de dentro dela. Por isso, dominar seu ritmo corporal, por meio da respiração, resulta em técnicas ricas a serem empregadas na narração.

"É preciso respirar junto com a história" (MACHADO, 2004a., p. 43), diz a contadora Regina Machado, acompanhar o narrador oral nos mínimos detalhes, "se ele respira a história, todo mundo respira junto. A respiração suspende e sustenta 0 fio da narrativa acima e além do tempo, no instante em que as horas param"(ibidem, p. 49). O ouvinte prende o ar junto com o contador, no suspense da história, ou solta gargalhadas catárticas de quase perder o fôlego, provocado pelas emoções do conto.

Desenvolvida com o auxílio do músculo diafragmático, pode ampliar tanto a resistência quanto a projeção da voz. Seu desenvolvimento é gradativo e aperfeiçoado por meio de exercícios diários e permanentes.

Em minha formação profissional, os estudos e práticas do Yoga mostraram ser comum, no homem ocidental, em alguns casos, conseguir recuperar até dois 
terços de capacidade respiratória quando bem exercitado. O ser humano deixa de respirar com o apoio dos músculos intercostais e diafragma, passa a respirar somente com a parte superior do pulmão, numa respiração de peito. Conseguir reverter essa respiração de peito para aquela com apoio do diafragma, com exercícios apropriados, pode aumentar bastante sua capacidade pulmonar e resistência do contador, ampliando possibilidades de técnicas vocais. As técnicas corporais da área do teatro também trabalham com a respiração, sendo importante para o contador o seu domínio, conquistado por seu próprio esforço.

Os contadores que fazem exercícios respiratórios e aquecimento vocal, antes de trabalhar com a palavra, seja falada ou cantada, no ensaio ou em apresentações, além de cuidarem da saúde, sem dúvida, se beneficiam da ampliação de possibilidades técnicas, adquiridas pela repetição.

\subsubsection{Pausa e silêncio no ato de contar}

A pausa é o tempo para o imaginário, a provocação de expectativas, o tempo para o ouvinte construir a imagem do que está sendo narrado. Como diz Fanny Abramovich (1985), "o tempo para construir o castelo, visualizar monstros, vestir a princesa ou o príncipe encantado...". A pausa é dada pelo contador, que escolhe os melhores momentos para que ela aconteça; faz parte do ritmo da narrativa.

É o primeiro elemento que Shedlock indica para a captura da atenção do ouvinte. "Em primeiro lugar, como forma de capturar instantaneamente a atenção do público, está a criteriosa pausa" (SHEDLOCK, 2004, p. 29). Criteriosa por ser um elemento poderoso na narração da história, capaz de imprimir o ritmo da narrativa e abrir o mundo imaginário.

O silêncio é a necessidade de um ambiente adequado para que a história seja ouvida por meio de palavras, sem dificuldades para a plateia interpretar, emocionarse e imaginar as ações da narrativa. Dito em outras palavras, o silêncio é a condição para a interação do contador com seu ouvinte, e a pausa é preenchida com o imaginário de ambos, construída na interação do olhar, no momento da significação do conto, um espaço mantido, propositadamente, para curtir e entender o que é narrado. Dessa forma, concordo com Cléo Busatto que "O silêncio na narração oral 
é uma das condições para encantar. Ele abre lacunas para que o ouvinte complemente a história, a partir da sua própria história” (2006, p. 73/74). Um espaço para a comunhão do conto, para elaboração de imagens, emoções e lembranças.

As variações no tempo da pausa devem respeitar sua condição de tempo para o imaginário, de acordo com: o texto, o contador e a plateia. "As gradações do silêncio de uma narração oral enchem o momento e o espaço de densidade. Multiplicam a história" (SISTO, 2004, p. 89). Identifico o silêncio como sendo da plateia, na respiração do conto, e a pausa provocada pelo contador, pensadas no momento da preparação da história.

Ao ler Baudelaire, Bachelard sublinha algumas palavras e percebe que, se colocar uma pausa entre elas, a experiência imaginária é intensificada. Afirma que

"(...) se fizermos uma pausa nas palavras sublinhadas eis que ela nos põe, corpo e alma, na maior tranquilidade. Sentimo-nos colocados no centro de projeção da casa do valezinho "vestidos" também com tecidos de inverno" (BACHELARD, 1988, p. 380).

Assim, o trabalho do contador é sublinhar as palavras do texto que conseguem suscitar o imaginário, transportando o ouvinte para o mundo da fantasia, ou para seu mundo interno, como uma infância na fazenda.

\subsubsection{O clima da história e do ambiente}

O clima constitui um elemento importante a ser trabalhado dentro da própria história. Segundo Regina Machado:

O clima de cada parte da história é resultante de um conjunto de elementos narrativos, animados por uma determinada pulsação. A pulsação da aventura é diferente da pulsação do amor, que é diferente da pulsação do medo ou do mistério, e assim por diante. O ritmo ou movimento da sequência narrativa é uma sucessão de diferentes climas, que caracterizam o modo como uma história respira. Viver uma história é respirar com ela. Dar vida a uma história é deixar-se conduzir pelas sucessivas mudanças em sua respiração (2004a., p. 55).

Os tipos de recursos escolhidos pelo contador conduzem o clima da história, em cada uma de suas partes, envolvendo ouvintes e determinando os ritmos, de acordo com os resultados de interação com a plateia. Mais uma vez, a 
experimentação é a única forma para essa aprendizagem. "O essencial de cada clima, de cada parte da história estava ali, conquistado, mil vezes visitado na experiência de estudar o conto" (MACHADO, 2004a., p. 52). A segurança do conto também é responsável pela manutenção do clima.

Alguns textos têm a necessidade de explicações anteriores, outros são apropriados para determinados ambientes, lugares e plateias. Outras histórias não podem ter seu título revelado antes de serem contadas, porque o título pode entregar o final da história, estragando a surpresa. Ocorre muito em contos de terror. Deixar para dizer o nome da história no fim, ou seja, depois de contar a história é uma opção. Título, autor, editora e ilustrador, quando houver, são as informações básicas de um livro, por isso, a necessidade de serem revelados. É comum, entre os contadores da atualidade, dizer que este é o endereço completo de uma obra literária.

Os cenários também intervêm na ambientação do espaço destinado à contação de histórias, desde a porta de chegada, até os mínimos detalhes, tudo interfere no clima do local. Porém, o cenário é algo simples, que não pode chamar mais a atenção do que a própria história. Os elementos cênicos são pensados, atendendo ao clima da sessão como um todo, sem exageros de apelos visuais. Regina Machado vai ainda mais fundo ao se referir ao espaço escolar. "É preciso uma parede limpa, ou um lençol estendido sobre ela, um espaço neutro para que as imagens das crianças possam se proteger sem a interferência de elementos alheios à história" (MACHADO, 2004a., p. 78). No meu entendimento, um espaço para ser preenchido pelo imaginário do ouvinte, e que seja afastado das imagens do cotidiano, sobretudo da mesmice da escola.

\subsubsection{Ajustes finais na preparação e apresentação das histórias}

Quando o contador conhece o seu público e suas características, ele pode escolher melhor uma história. Entretanto, por mais desconhecida que seja uma plateia, o tipo de evento e o local já trazem algumas informações. Na organização ou participação de um evento que envolve o contador de histórias, minha experiência 
revela cinco pontos que podem interferir em termos de eficácia e eficiência, quanto às suas adequações: local, espaço, público, linguagem e voz.

a. Local - com a pouca valorização da arte em nosso país, na atualidade, tem sido comum encontrar auditórios fechados, sobretudo, em escolas e interiores. Estar atento às condições de uso, observando a iluminação, ventilação e higiene do local, fazem parte da responsabilidade do contador. A acústica do local é de fundamental importância, podendo inviabilizar a sessão de histórias, como foi explicado na reverberação. O exemplo a seguir demonstra a situação: estávamos em um evento, no auditório da Câmara dos Deputados, em Brasília, comemorando o 'Dia do Contador de Histórias', quando o local foi invadido, subitamente, por uma fumaça um tanto densa, e com um cheiro muito forte. Celso Sisto estava no meio de sua palestra, que seria encerrada por uma grande roda de histórias, na Torre da cidade, local próximo ao evento. O clima de desconforto se instalou e o foco mudou: o que fazer? O evento continuou, do lado de fora, com a prometida sessão de autógrafos, mas a garantia da 'sessão de histórias de encerramento', marcada para a Torre, amenizava as frustrações daquela interrupção acidental. Este último local se mostrou inapropriado para o que se queria, pelo excesso de barulho em volta (pois o local escolhido foi ao lado de um restaurante) e o excesso de vidros e azulejos que dão continuidade à reverberação do som, inviabilizavam a audição da fala. Nesse caso, a insistência põe em risco a qualidade do trabalho do narrador.

b. Espaço - se refere à distância entre o contador e a plateia. Como a proposta é não fazer ou obedecer a regras, quanto mais aconchegante, melhor! E esses termos podem ser compreendidos de maneiras diferentes. Alguns preferem contar sentados e em círculo, outros precisam de um espaço para se movimentar, pela performance elaborada. Porém, reconheço que na escola é preciso sair das carteiras em fileiras militares. Definitivamente, a nuca ou cabeça do colega da frente não tem haver com o imaginário despertado pelos contos.

c. Público - cada público tem sua especificidade, sendo possível conhecer suas características (idade, tipo de evento, objetivo, interesse 
específico etc.), havendo, inclusive, estudos indicativos na literatura infantil de Beth Coelho (1999). A literatura moderna, muitas vezes, vem endereçada a cada fase ou faixa de interesse, por sua linguagem, assunto/tema, ilustração e forma. Faz parte do trabalho do contador, conhecer e escolher. Tenho reafirmado, em diversas oportunidades, o sucesso das histórias orais e tradicionais do meu repertório para públicos mistos (tanto em idade como em classe social).

d. Linguagem - a linguagem da história tem que estar de acordo com a capacidade de apreensão e interesse do público a que se destina, com foco na possibilidade de entendimento. A discussão da sociolinguística, apresentada no quarto capítulo, fornece subsídios para compreensões e escolhas da linguagem a ser utilizada. Os cuidados com preconceitos merecem observação e superação, em todos os níveis.

e. Voz - merece atenção e cuidados especiais, pois é explorada em sua dimensão individual, como única, própria de cada um. A voz se ajusta ao local/ambiente e ao tipo de plateia, fazendo-se uso de variações dos parâmetros sonoros. Porém, o uso de som mecânico, antes do uso da voz acústica, pode interferir na audiência, prejudicando-a. Em minha experiência, desligando o som, um pouco antes, dando um tempo para os ouvidos se acostumarem à nova ambientação acústica, melhora a produção sonora da voz. Tema que pode ser aprofundado com os estudos de César Lignelli (2011).

Enfim, de nada valem esses recursos, se o contador não souber ouvir. Escutar o outro e a si mesmo, dominar sua linguagem e se libertar para criar. Concordando com a autora: "Audição: sentido um pouco fora de uso nos dias de hoje. Ouvimos pouco, falamos muito e desviamo-nos frequentemente dos nossos propósitos, diante das distrações oferecidas pelo mundo moderno" (BUSATTO 2012, p. 40). Para mim, tem sido justamente ouvir e contar histórias a minha conexão com as coisas importantes do mundo. Meu jeito de educar, de ser, de compartilhar e de me redescobrir, a cada nova história. 
Ao explorar os aspectos da linguagem corporal, tanto em sua oralidade quanto em sua gestualidade e ritmo, cada contador aprende a se conhecer, descobrindo quais recursos são mais eficientes para cada texto e contexto escolhido. O conhecimento desses recursos está intimamente relacionado com 0 autoconhecimento que cada um tem de si e de suas potencialidades. Nesse sentido, assumo que os caminhos para o conhecimento e desenvolvimento da linguagem corporal do narrador oral pertencem às escolhas e particularidades de cada um. Ao reconhecer seus limites, o contador pode se decidir por respeitá-los ou ampliá-los com trabalhos específicos. As experiências, aqui relatadas, são ideias ou pontos de partidas, para serem experimentadas e/ou adaptadas a cada realidade, não para serem copiadas, como em um modelo. Cada corpo carrega sua biografia e a direção proposta para a aprendizagem do narrador, que do meu ponto de vista, tem que respeitar e recuperar o respeito por sua própria história. Autoconhecimento é o fundamento para a construção das técnicas da linguagem corporal do contador de histórias.

Concluo que a linguagem corporal do contador de histórias oferece inúmeros recursos a serem empregados em uma narração de histórias. As decisões de quais serão os melhores recursos pertencem a cada contador.

Passo, então, a um ponto final, em todo este processo, porque fechar é preciso, embora uma conclusão também esteja sujeita a abertura de novos caminhos e novas transformações. 


\section{CONSIDERAÇÕES FINAIS}

Conto o que me encontra e me encanta, de tudo aquilo que me contam...!

Quando se fala em contar histórias, o momento final pode trazer também o significado de novos inícios e aqui, ao elaborar uma síntese sobre o processo da pesquisa, reencontro o desejo de continuar ouvindo e contando histórias... Nesta síntese encontro novas forças e possibilidades de encantamento por meio das reflexões e estudos desenvolvidos durante o processo.

No início da pesquisa, ainda na fase da definição do projeto, a ideia da țese girava em torno da teorização dos elementos expostos em um quadro de recursos (Anexo 1) que foi por mim construído, utilizado e modificado nos cursos e oficinas durante vinte anos como Contadora de Histórias. Entretanto, ao aprofundar as investigações, com as leituras, orientações, análises e reflexões, outras necessidades foram se impondo, e a consequente reestruturação resultou na organização apresentada, que embora conserve a maioria dos recursos ali explicitados como elementos constitutivos das técnicas corporais dos contadores, traz outras compreensões que não ficam limitadas à uma forma ou modelo, explícito em um quadro.

A estrutura apresentada no sumário é resultado de longas e profundas reflexões sobre os resultados das práticas dos alunos nas oficinas e cursos, dos planejamentos e práticas que possibilitaram as experiências desses alunos e em minha própria experiência como contadora. $E$, se a intenção da presente investigação é apresentar contribuições àqueles que querem se assumir como contadores de histórias são os princípios e fundamentos (entendidos como aqueles que orientam, explicam, dão sentido e significado às nossas práticas) que devem estar presentes nas ações do contador do início ao fim da narração.

Assim, para que cada um possa se assumir contador de histórias por meio de sua escolha, ofereço algumas considerações sobre os princípios que orientam a prática do contar e, os fundamentos que dão subsídios e elucidam essas práticas respeitando os diversos objetivos, estéticas e éticas de cada contador.

A estrutura apresentada na pesquisa encontra em seus princípios descritos nos dois primeiros capítulos, o esclarecimento do contexto da investigação e do sujeito que determina seu objeto. O contexto da pesquisa verificado pelos conceitos 
de cultura, educação e arte são acatados como princípios que apoiaram minhas escolhas e direções, onde encontro embasamento: na dinamicidade da cultura; na educação como troca e transformação das pessoas, por meio de experiências pessoais e coletivas; na contação de histórias na perspectiva do ensino de arte (na escola), com possibilidades de vivência de emoções e subjetividades nem sempre permitidas nos espaços escolares; da ludicidade como estratégia na aprendizagem de contar, inseparável na constituição e descoberta de potencialidades individuais e coletivas, por ser condição inerente ao ser humano, com poucos espaços para sua manifestação.

Isso quer dizer que quanto mais a cultura for considerada como diferente diversa no lugar de estranha ou qualquer outro adjetivo qualificativo; quanto mais o professor ouvir seus alunos contando histórias; quanto mais o contador conseguir envolver o ouvinte em sua história, mais eficiente será a ação de contar. Ou seja, mais o ouvinte é atraído para dentro da história, chegando a vivenciá-la, por meio das imagens e emoções suscitadas pelo conto. Outro ponto que fica claro em minha experiência é a importância de um clima descontraído e propício à criação, conquistado pela presença das atividades lúdicas desenvolvidas, por exemplo, para trabalhar os recursos da linguagem corporal e outras técnicas.

$\mathrm{Na}$ definição do sujeito da pesquisa o contador de histórias é aquele que escolhe ser um narrador oral e se prepara para isso, sendo grande parte da experiência relatada justamente a preparação do contador e da história a ser contada. Sendo a escolha uma condição para ser um contador, podemos dizer que a audição é o primeiro fundamento para 0 aprendiz de contador na contemporaneidade.

Saber ouvir é significar o conto junto com contador. É na comunhão do conto que o contador se faz presente, por meio do "contar com". A esta presença do narrador, atribuo os fundamentos da memória, imaginação, emoção e espontaneidade.

Nesse sentido, o contar com é se fazer presente na significação do conto, correspondendo simultaneamente à significação de ambos, contador e ouvinte, perante a obra narrada. A presença é atribuída à memória do contador, que traz à tona a memória coletiva dos ouvintes por meio do imaginário do conto, suscitado pelas emoções e imagens provocadas pelas técnicas da linguagem corporal. A espontaneidade entra como fundamento que conecta contador e ouvinte na 
comunhão do conto, ou seja, na compreensão de seus significados. Isso dá a entender que o contador além de estudar muito, continua improvisando e acompanhando o contexto de seu público.

Entretanto, para a conquista dessa presença é necessário saber escolher e preparar uma história, sem, contudo, atender a um modelo. Saber escolher respeitando a direção de seus objetivos exige do contador, além da ampliação do repertório, o conhecimento de estilos, estéticas, éticas, estruturas de textos e formas variadas de compreensão e conhecimento do conto. O fundamento: "conhecer para escolher" se relaciona ao princípio da educação que acredito, e que mantém o professor em constante reflexão ${ }^{145}$, pois envolve autonomia do aluno em relação à elaboração de seus próprios critérios de escolha, para sua atuação no mundo, por meio de sua identidade.

Levando-se em conta a diversidade de objetivos e contextos, o fundamento que orienta a escolha e a preparação do conto é o conhecimento. Autonomia é construída com responsabilidade que pressupõe estudo de um amplo repertório para ampliar escolhas. Conhecer a língua e as discussões sobre ela faz parte do conhecimento de um contador preocupado com o entendimento das diferenças entre o mundo letrado e a cultura oral.

A preparação do conto toma como base o conhecimento da estrutura do texto e definição dos objetivos de cada narração oral, assim como a escolha da linguagem e das técnicas corporais a serem empregadas na narração da história. $O$ conhecimento e a atitude reflexiva do contador de histórias orientam as consequências de seu fazer.

Deste modo, apontar a escolha e preparação de um conto como fundamentos na descoberta do contador de histórias pressupõe: conhecer a diversidade de contos existentes dentre os populares e/ou autorais, nas mais variadas culturas e etnias; definir a linguagem a ser utilizada com base em seus próprios objetivos e/ou contextos, compreendendo as diferenças entre oralidade e escrita; e, elaborar formas de preparar cada história, que vão sendo organizadas com as experiências práticas de contar, ouvir e refletir seu próprio fazer. A responsabilidade da

\footnotetext{
145 Reflexão permanente mantida pelas perguntas: que sociedade eu tenho? Que sociedade eu quero ajudar a construir? Que aluno eu tenho? Que aluno eu quero ajudar a construir? (Questões apresentadas no primeiro capítulo, que considero ser uma síntese da experiência da mãe/educadora que ainda tenho a meu lado, em um permanente diálogo, questionamentos, reflexões...).
} 
preparação de uma história está na eficiência de sua contação, no envolvimento de seus ouvintes e na significação do conto.

Considerar a contação de histórias na perspectiva da arte é apreciar as várias possibilidades de interpretação por parte dos ouvintes e contadores na presença e ação do contar, assim como avaliar ou ponderar, sobre a eficiência das formas, linguagens e técnicas utilizadas na narração.

O emprego das técnicas da linguagem corporal por meio da oralidade, gestualidade e ritmo, se constitui por meio do fundamento do autoconhecimento, das potencialidades de seu corpo e de sua disposição para ampliar suas possibilidades de significação simultânea do conto. Ao admitir a existência de um corpo que conta junto com o contador, explorar suas possibilidades técnicas pode permitir a ampliação da eficiência na narração de histórias, conduzindo o ouvinte para dentro dela, suscitando-Ihe as imagens e emoções do conto.

Ao pesquisar as técnicas corporais para a constituição de um contador de histórias na contemporaneidade, assumo o campo das Artes Cênicas, como grande possibilidade de aprofundamento em suas contribuições recíprocas, para o ator e para o contador de histórias. As teorias que envolvem o conhecimento da oralidade por meio dos parâmetros do som e de uma gestualidade e ritmo são constituídas com base em uma experiência pessoal intransferível. E, é com base nesse conhecimento e nessa experiência que o contador de histórias se constitui, se conhece e consegue conversar com a história dentro de si, consequentemente conversar também com o ouvinte.

Os recursos técnicos são descritos com base em experiências empíricas, mas os resultados ao longo destes anos me apontam que nem todos os recursos descritos são utilizados ao mesmo tempo ou em uma mesma história. O contador vai se constituindo, se enriquecendo de elementos que atraem o ouvinte para dentro da narração.

A preparação é o momento das experimentações. Depois de escolhidas e treinadas as técnicas são deixadas de lado e o contador acaba descobrindo que tudo "isso ou aquilo" já existia dentro dele, às vezes à espera de ser acordado. Ele é que não sabia que sabia!

Outra conclusão a que cheguei foi possibilitada pela observação constante na interação entre ouvinte e contador, com relação às características dos ouvintes. Contar histórias para as crianças é estimular a abertura de seus olhos, deixando-os 
curiosos e inquietos diante das imagens e emoções que vão se formando; contar histórias aos jovens e adultos é exercitar os olhos abertos para as coisas novas do mundo. Portanto, acredito que contar e ouvir histórias não se direciona à uma idade específica ou qualquer indicação exclusiva, como na maioria das atividades do mundo contemporâneo, uma vez que esta atividade sempre esteve envolvida no fazer humano, independentemente de suas características. É possível afirmar que contar e ouvir histórias é uma arte sem idade!

As questões levantadas ao longo da redação, que serviram de direção na busca dos fundamentos que orientam a prática de um narrador oral são agora retomadas para averiguação e síntese de possíveis respostas. $\mathrm{Na}$ investigação do problema proposto identifico que somos parte de um movimento de novos contadores de histórias na contemporaneidade, que aparece em várias partes do mundo (Américas e Europa). São novos estudos que aproximam e/ou distanciam dos contadores de histórias tradicionais, ampliando perspectivas, resignificando fazeres, dinamizando culturas. Pertencem à várias áreas do conhecimento, sendo caracterizada como atividade humana, que no contexto desta pesquisa foi considerada como atividade artística a ser desenvolvida na educação, seja dentro ou fora da escola.

Ao entender a educação em seus significados mais amplos, reconhecendo sua ação tanto dentro como fora da escola, considero a narração oral como um ato educativo, identificando a força de transformação e envolvimento presentes nesta atividade. E é neste sentido que afirmo que qualquer pessoa que se disponha pode se tornar um contador de histórias na contemporaneidade, sendo encontradas uma grande diversidade de propostas em cursos e oficinas, por todo o Brasil. Assim aluno e professor, são ao mesmo tempo sujeitos nesta pesquisa, uma vez que os dois podem assumir a arte de contar histórias como protagonistas de suas ações.

Outra observação que pode ajudar a relativizar possíveis generalizações diz respeito à diversidade e/ou multiplicidade de realidades brasileiras, no que se refere à educação, não sendo possível identificar um único tipo de escola, de professor ou de aluno. Minha experiência com a educação básica encontra referências no Estado de Goiás, do qual situo e contextualizo as críticas e denúncias, que são parte de minha luta pessoal de artista e educadora.

Uma das dificuldades recorrentes no percurso foi a importância de deixar clara as restrições e limites que circundam o objeto, uma vez que a prática revela: 
uma formação sem forma; uma construção que não seja rígida; uma descoberta que não precisa necessariamente ser uma novidade; um desenvolvimento sem linearidade. Uma elaboração do contador de histórias da atualidade, se for possível que este seja considerado em sua dinamicidade e maleabilidade de fronteiras. Uma dificuldade que acabou simplificando o título, na intenção de não comprometer ou definir o contador de histórias, sem antes alertar para o fato de que cada um entra em contato com o seu próprio contador, por meio de suas escolhas.

Como educadora, não quero certezas. Reivindico o direito garantido a dúvida! Essa sim me faz seguir adiante e me faz: narradora oral.

Que cada vez mais se cultivem rodas de histórias nos mais variados e inusitados espaços, com mais contadores e ouvintes envolvidos nas tramas, emoções e imagens suscitadas pela narração, ampliando possibilidades de visões de mundo que respeitem a diversidade existente se valendo desta para expandir conhecimentos e experiências. 


\section{REFERÊNCIAS}

ABREU, Joana. Teatro e culturas populares: diálogos para a formação do ator. Brasília: Teatro Caledoscópio: Editora Dulcina, 2010. p. 37/172;

ANDRADE, Aldanei Menegaz. Quem conta um conto aumenta um ponto: contadores de histórias no Distrito Federal (1991 a 2011). Brasília: Dissertação de Mestrado - UnB - história cultural, 2012. p. 67/91/92102/105/230;

ARAÚJO, Silvana Silva de Farias. O embate norma popular/ norma culta/ norma padrão: implicações no trabalho com análise linguística para falantes do português rural afro-brasileiro. Florianópolis: UEFS, 2008. p. 169/170;

BACHELARD, Gaston. A poética do devaneio. São Paulo: Martins Fontes, 2000. p. 132/145;

. Os Pensadores. São Paulo: Nova Cultural, 1988. p. 212/247;

BAIRD, Margarida. "Contando e aprendendo." In: Baús e chaves da narração de histórias, por Gilka GIRARDELLO, 72 à 80. Florianópolis: SESC/SC, 2004. p. 152/154/195/242;

BANDINI, Alice. "Rumo de uma escolha." In: $A$ arte de encantar: o contador de histórias contemporâneo e seus olhares., por Fabiano e GOMES, Lenice MORAES, 79 à 95. São Paulo: Cortez, 2012. p. 103/160;

BARBOSA, Ana Mae. (Org). Inquietações e mudanças no ensino da arte. 4a . São Paulo: Cortez, 2008. p. 26/45/73/125/165;

BEDRAN, Bia. "Impressões de uma contadora de histórias." In: Contadores de histórias: um exercício para muitas vozes, por Benita PRIETO, 59 à 65. Rio de Janeiro: Prieto Produções Artísticas, 2011. p. 57/93/102/104/115/117/155;

BELLO, Sérgio Carneiro. "Por que devemos contar histórias na escola?" In: Baús e chaves da narração de histórias, por Gilka GIRARDELLO, 156 à 162. Florianópolis: SESC/SC, 2004. p. 138/211/228;

BENJAMIN, Walter. O narrador (coleção Os pensadores). São Paulo: Abril Cultural, 1975. p. 52/73/74/123/124/129/130/141/142/147/172/210;

BETHELHEIM, Bruno. A psicanálise dos contos de fadas. Rio de Janeiro: Paz e Terra, 1984. p. 151/152/177;

BORTONI-RICARDO, Stella Maris. Nós cheguemu na escola, e agora? Sociolinguística \& Educação. São Paulo: Parábola Editorial, 2005. p. 169; 
BRANDÃO, Carlos Rodrigues. Lutar com a palavra. 2ed. Rio de Janeiro: Graal, 1985. 28/30/38/69/70;

. O que é educação? São Paulo : Brasiliense, 1995. p. 30/33/38/191;

. O que é folclore. São Paulo: Brasiliense, 1982. p. 31/36;

BRANT, Mauro. "A terceira margem da cena." In: Contadores de histórias: um exercício para muitas vozes, por Benita. (Org) PRIETO, 67 à 71. Rio de Janeiro: Prieto Produções Artísticas, 2011. p. 105/125/207/208;

BRENMAN, Illan. Através da vidraça da escola: formando novos leitores. Belo Horizonte: Aletria, 2012a. p. 164;

- Ilan. A condenação de Emília: O politicamente correto na literatura infantil. Belo Horizonte: Aletria, 2012b. p. 209;

BUSATTO, Cleo. A arte de contar histórias no século XXI: tradição e ciberespaço. Petrópolis: Vozes, 2006. p. 69/70/73/76/102/104/105/107/108/109/110/113 /114/119/122/133/137/139/141/191/229/230/231/232/243/245/247;

Cleo. "Paiquerê, Piquiri, Fietó: um experimento com as linguagens." In: Contadores de histórias: um exercício para muitas vozes., por Benita. PRIETTO, 101 à 103. Rio de Janeiro: Prieto Produções Artísticas, 2011. p. 123/130/131/148;

Cléo. Contar e Encantar: Pequenos segredos da narrativa. Petrópolis RJ: Vozes, 2012. p. 103/190/2041/205/207/212/230/231/250;

CAFÉ, Ângela Barcellos. Dos contadores de histórias e das histórias dos contadores. Goiânia: Cegraf/UFG, 2005. p. 15

CASCUDO, Luis da Câmara. Lendas Brasileiras. 8. São Paulo: Global, 2002. p. 70/87/91/179;

CAVALCANTI, Maria Auxiliadora da Silva. ebookbrose. Edição: UFAL. 2011. http://ebookbrose.com/contibuicoes-da-sociolinguistica-educacional-para-oprocesso-ensino-e-aprendizagem-da-linguagem-doc-d39332490 (acesso em 6 de Abril de 2013). p. 169/170;

CHEKHOV, Michael. Para o Ator. São Paulo: Martins Fontes, 2010. p. 239;

COELHO, Beth. Contar histórias: uma arte sem idade. São Paulo: Ática, 1999. p.250;

COELHO, Nely Novaes. Os contos de fadas: símbolos, mitos e arquétipos. São Paulo, DCL, 2003. p. ???? 
CORALINA, Cora. Poemas dos Becos de Goiás e estórias mais. São Paulo: Global, 1997. p. $122 / 144 / 158 / 188 / 241$;

COSTTA, Sílvio. Como contar histórias usando sons: uma introdução à percepção e educação sonora. São Paulo: Editora Ave Maria, 2008. p. 228;

DA MATTA, Roberto. Você tem cultura? Rio de Janeiro: Jornal da Embratel, 1981. p. 33;

DELEUZE, Giles, e Felix GUATTARI. O que é filosofia? São Paulo: Editorial Presença, 1992. p. 20;

DOHME, Vânia. Técnicas de contar histórias: um guia para desenvolver suas habilidades e obter sucesso na apresentação de uma história. São Paulo: Informal editora, 2000. p. 191/196;

DUARTE JR, João Francisco. Fundamentos estéticos da educação. Campinas SP: Papirus, 1988. p. 125;

DUMAZEDIER, J. Valores e conteúdos culturais do lazer. São Paulo: Sesc, 1986.

FARIAS, Carlos Ademir. "Contar histórias é alimentar a humanidade da humanidade." In: Contadores de histórias: um exercício para muitas vozes., por Benita PRIETO, 19 à 22. Rio de Janeior: Prieto roduções Artísticas, 2011. p. $123 / 124$;

FARIAS, Vitória, e Fátima SALLES. "Currículo na Educação Infantil: diálogos com os demais elementos da proposta pedagógica." Percursos (Scipione), 2007. p. $47 / 48 / 51$;

FERREIRA, Aurélio Buarque H., e Renan. RÓNAI. Mar de histórias: antologia do conto mundial. Rio de Janeiro: Nova Fronteira, 1998. p. 174/175/219;

FOX, Geof. IN CABRAL, Beatriz. (org). $O$ ensino do teatro: experiências interculturais. Florianópolis: Imprensa Universitária, 1999. p. 79;

, Geoff, e Gilka GIRARDELLO. "A narração de histórias na sala de aula." In: Baús e chaves da narração de histórias, por Gilka GIRARDELLO, 116 à 154. Florianópolis: SESC/SC, 2004. p. 119/130/136/140/155/160/194;

FRANCO JR., Hilário. A eva barbada: Ensaios de mitologia medieval. São Paulo: EDUSP, 1996. p. 38;

GARCIA, Carles. In GOMES, Lenice e MORAES, Fabiano. (orgs). A arte de encantar: o contador de histórias contemporâneo e seus olhares. São Paulo: Cortez, 2012. p. 90;

GEERTZ, Cliford. A interpretação das culturas. Rio de Janeiro: Guanabara Hoogan, 1989. p. 30/31/34; 
GIORDANO, Alessandra. Contar histórias:um recurso terapeutico de transformação e cura. São Paulo: Artes Médicas, 2007. p. 152/178;

GIRARDELLO, Gilka. Televisão e Imaginação Infantil: Histórias da Costa da Lagoa. Tese de Doutorado. São Paulo: USP, 1998. p. 54/118/122/130/131/ 132/135/139/140/141/190/197/210;

, Gilka. Baús e chaves da narração de histórias. Florianópolis: SESC/SC, 2004. p. 69/72/104/115/120/136/140/156/194/241;

, Gilka. "Na clareira do presente: o diálogo narrativo entre as gerações." In: A arte de encantar: o contador de histórias contemporâneo e seus olhares., por Fabiano \& GOMES, Lenice. MORAES, 41 à 58. São Paulo: Cortez, 2012. p. 100/107/118/128/130;

Gilka. Um roteiro teórico-literário para pensar o papel da narração oral hoje. Signo, 2014: 3 à 21. p. 48/50/52/57/58/60/65/110/111/121/ 132/137/189/190;

GOMES, Lenice. Cantares e contares: brincadeiras faladas - A arte de contar histórias e as brincadeiras faladas. In: $A$ arte de encantar o contar histórias contemporâneo e seus olheres., por Fabiano \& GOMES, Lenice MORAES, 23 à 40. São Paulo: Cortêz, 2012. p. 118/123/210;

GROTAWSKI, Jerzy. O teatro laboratório de Jerzy Grotowski (1959-1969). São Paulo: SESC/Perspectiva, 2007. p. 214;

HADDAD, Amir. Espaço." In: Testro de rua: olhares e perspectivas, por Narciso E CARNEIRO, Ana TELLES, 60 à 74. Rio de Janeiro: E-Papers Serviços editoriais, 2005. p. 240;

HARTMANN, Luciana. Gesto, palavra e memória: performances narrativas de contadores de causos. Florianópolis: Ed. Da UFSC, 2011. p. 65/83/84/ 129/179;

HUIZINGA, Johan. Homo Ludens. São Paulo: Perspectiva, 1971. p. 30/62;

JOSÉ, Elias. Memória, cultura e literatura: o prazer de ler e recriar o mundo. São Paulo: Paulus, 2012. p. 114/116/118/120/121/122/123/125/128/131/136/ 197/200;

KRAMER, Sônia. Profissionais da Educação Infantil: gestão e formação. São Paulo: Ática, 2005. p. 47/49;

LAKATOS, Eva Maria, e Marina de Andrade MARCONI. Fundamentos de Metodologia científica. 5ạ. São Paulo: Atlas, 2003. p. 20/21;

LARAIA, Roque de Barros. Cultura: Um conceito antropológico. Rio de Janeiro: Zahar, 2004. p. 35; 
LATERZA, Moacir, e Terezinha. RIOS. Filosofia da educação: fundamentos. São Paulo: Herder, 1971. p. 30/33/174;

LIGNELLI, César. Sons \& Cenas: apreensão e produção de sentido a partir da dimensão acústica. Tese de Doutorado, Brasília: UnB, 2011. p. 205/214/215/ 216/217/218/219/220/221/222/223/226/244/250;

MACHADO, Ana Maria, e Ruth ROCHA. Contando histórias, formando leitores. São Paulo: Papirus 7 Mares, 2011. p. 54/67;

MACHADO, Regina. Acordais: fundamentos teóricos-poéticos da arte de contar histórias. São Paulo: DCL, 2004a. p. 50/51/63/69/70/73/100/109/112/115/133/ 134/135/136/137/138/140/146/151/153/182/190/191/195/198/200/203/204/207 /227/237242/243/245/247/248;

Regina. "No tempo em que não havia tempo." In: Baús e chaves da narração de histórias, por Gilka GIRARDELLO, 38 à 53. Florianópolios: SESC/SC, 2004b. p. 142/150/199;

Regina. "E eles foram felizes para sempre." In: Contadores de histórias: um exercício para nuitas vozes, por Benita PRIETO, 196 à 201. Rio de Janeiro: Prieto Produções Artísticas, 2011. p. 134;

MAGALHÃES, Ivani. “"Era uma vez” um breve histórico das histórias para crianças.” In: $A$ arte de contar histórias: abordagens poética, literária e performática., por Giuliano (Org.) TIERNO. São Paulo: Ícone, 2010. p. 175;

MARCELLINO, Nelson de Carvalho. Estudos do Lazer: Uma nova introdução. Campinas: Autores Associados, 1996. p. 30; , Lazer \& Educação. Campinas: Papirus, 1987. p. 30; , Pedagogia da animação. Campinas: Papirus, 1991. p. 30;

MARCUSE, H. Algumas implicações sociais da tecnologia moderna. In: Tecnologia, Guerra e Fascismo. São Paulo: Unesp, 1999. p. 49;

MARIANO, Conrado. "O paciente como contador de sua própria história: o olhar de um médico homeopata." In: Contadores de histórias: um exercício para muitas vozes., por Benita PRIETO, 209 à 212. Rio de Janeiro: Prieto Produções Artísticas, 2011. p. 148;

MARTINS, Georgina. "Jornal da creche da UFMG." Contos de fadas mal assombrados. Belo Horizonte: UFMG, outubro de 1994. p. 70/232;

MATOS, Gislayne Avelar. A palavra do contador de histórias. São Paulo: Martins Fontes, 2006. p. 70/99/139/151/190; 
, Gislayne Avelar, e Inno SORSY. O ofício do contador de histórias. São Paulo: Martina Fontes, 2009. p. 69/73/173/176/178/179/191/195;

, Gislayne Avelar. "Mergulhados em beleza." In: $A$ arte de encantar: 0 contador de histórias contemporâneo e seus olhares., por Fabiano \& GOMES, Lenice MORAES, 111 à 131. São Paulo: Cortez, 2012. p. 79/90/205/212;

MELLON, Nancy. A arte de contar histórias. Rio de Janeiro : Rocco, 2006. p. 153;

MENDES, Cristiano Mota. "O ofício de viver contando histórias." In: Contadores de histórias: um exercício para muitas vozes, por Benita Prieto, 240. Rio de Janeiro: Prieto Produções Artísticas, 2011. p. 108/119;

MENDONÇA, Marina Célia. A luta pelo direito de dizer a língua: a linguística e o purismo linguístico na passagem do século XX para o século XXI. Vers. v. 12. Sínteses - Revista dos cursos de pós graduação. 2007. http://www.google.com/search?q=A+LUTA+PELO+DIREITO+DE+DIZER+A+L $\%$ C2\%8DNGUA\%3A+A+LING\%C3\%9C\%C3\%8DSTICA+E+OPURISMO+LIN G\%C3\%9C\%C3\%8DSTICO+NA+PASSAGEM+DO+S\%C3\%89CULO+XX+PA RA+OS\%C3\%89CULO+XXI1\&ie=utf-8\&aq=t\&rls=org.mozilla:pt-

BR:official\&client=firefox-a\&channe (acesso em 6 de Abril de 2013). p. 170;

MENESES apud GIRARDELLO, Gilka. Televisão e imaginação infantil: histórias da Costa da Lagoa; São Paulo: ECA/USP, 1998. p. 118;

MORAES, Fabiano. Contar histórias: a arte de brincar com a palvras. Petrópolis RJ: Vozes, 2012. p. 120/122/189/197/200;

MORIN, Edgar. A cabeça bem feita: repensar a reforma - reformar o pensamento. Rio de Janeiro: Bertrand do Brasil, 2000. p. 131;

NÓBREGA, Antônio. Entrevista Roda Viva. Rio de Janeiro: TV Cultura, 2015. p. 37;

NOVAES, Ana Maria Pires. "Intercâmbio entre oralidades e escrita em práticas discursivas escolares." 2011. http://www.xiconlab.eventos.dype.com.br/resources/anais/3/1308360342_AR QUIVO_INTERCAMBIOENTREORALIDADEEESCRITAEMPRATICASDISCU SIVASESCOLARES.pdf (acesso em 8 de Abril de 2013). p. 170;

ONG, Walter. Oralidade e cultura escrita. Campinas, SP: Papirus, 1998. p. 209;

ORTIZ, Estrella. "Ler, interpretar, recitar..." In: Baús e chaves da narração de histórias, por Gilka GIRARDELLO, 104 à 114. Florianóolis: SESC/SC, 2004. p. 114/116/117/157/187/214/227;

PATRINI, Maria de Lourdes. A renovação do conto: emergência de uma prática oral. São Paulo: Cortez, 2005. p. 70/89/90/91/92/93/94; 
PÉREZ, Elvia. "El arte de contar histórias y el teatro." In: $A$ arte de encantar: o contador de histórias contemporâneo e seus olhares, por Lenice e MORAES, Fabiano GOMES, 133 à 173. São Paulo: Cortez, 2012. p. 210;

PESSOA, Augusto. "Contando na telinha." In: Contadores de histórias: um exercício para muitas vozes, por Benita PRIETO, 79 à 83. Rio de Janeiro: Prieto Produções Artísticas, 2011. p. 135;

PIACENTINI, Tânia. "Histórias e mais histórias." In: Baús e chaves da narração de histórias, por Gilka Girardello, 185. Florianópolis: SESC/SC, 2004. p. 117;

PRIETO, Benita (org.). Contadores de histórias: um exercício para muitas vozes. Rio de Janeiro: Prieto Produções Artísticas, 2011. p. 69/79/94/95/177;

RABETTI, Beti. Memórias e culturas do "popular" no teatro: o típico e as técnicas. Vol. 8. X: O Percevejo, 2000. p. 35/36;

RAMALHO, Daniele. "Contos indígenas, uma experiência com narrativas dos primeiros povos brasileiros." In: Contadores de histórias: um exercício para muitas vozes., por Benita PRIETO, 25 à 29. Rio de Janeiro: Prieto Produções Artísticas, 2012. p. 120

RIGOLET, Sylviane A. Ler livros e contar histórias com as crianças: como formar leitores activos e envolvidos. Porto - Portugal: Porto Editora, 2009.

ROCHA, Gilmar. Cultura Popular: do folclore ao patrimônio. x: y, 2007. p. 31/36;

ROCHA, Vivian Munhoz. "Aprender pela arte a arte de narrar: educação estética e artística na formação de contadores de histórias." Tese de Doutorado. São Paulo: Escola de comunicação e artes da Universidade de São Paulo, 2010. p. 37/69/70/71/78/81/82/104;

SANT'ANA, Afonso Romano de. "Contação de histórias: Vida e realidade." In: Contadores de Histórias: Um exercício para muitas vozes, por Benita. (Org) PRIETO, 13-17. Rio de Janeiro: Prieto Organizações, 2011. p. 70/75/91/177;

SANTOS, Daniel Rosa dos. "Casos dos cursos de formação: conjecturas de um contador." In: Baús e chaves da narração de histórias, por Gilka GIRADELLO, 164 à 180. Florianópolis: ESEC/SC, 2004. p. 104/138/150;

SANTOS, Robson. IN PRIETO, Benita. (org). Contadores de histórias: um exercícios para muitas vozes. Rio de Janeiro: Prieto Produções Artísticas, 2011. p. 70/80;

SCHAFF, Adam. História e verdade. São Paulo: Martins Fontes, 1986. p. 163;

SCHCOLNIC, Clarice, e Fernando BEZERRA. Contadores de História: Sobre a Arte da Narrativa. São Paulo: All Print Editora, 2008. 
SCIESZKA, Jon. A verdadeira história dos três porquinhos. São Paulo: Cia das Letrinhas, 2005. p. 201;

SHELDLOK, Marie. "Da introdução à arte de contar histórias." In: Baús e chaves da narração de histórias, por Gilka GIRARDELLO, 20 à 35. Florianópolis: SESC/SC, 2004. p. 106/138/154/157/159/197/227/246;

SIMMS, Laura. "Através do terror da história." In: Baús e chaves da narração de histórias., por Gilka GIRARDELLO, 58 à 68. Florianópolis: SESC/SC, 2004. p. 113/152/156/158/205;

SISTO, Celso. "O misterioso momento: a história do ponto de vista de quem ouve (e também vê!)." In: Baús e chaves da narração de histórias, por Gilka Girardello, 82 a 93. Florianópolis: SESC, $2004 . \quad p$. 79/101/109/112/139/151/233/247;

, Celso. Textos \& pretextos: sobre a arte de contar histórias. Belo Horizonte: Aletria, 2012a. p. 111/134/137/146/147/149/150/154/159/160/191/194/204/ 210/212/224/232/233;

SLADE, Peter. O jogo dramático infantil. São Paulo: Summus, 1978. p. 56;

SOARES, Maria de Lourdes. "As águas da memória e os guardadores da corrente de histórias." In: Contadores de histórias: um exercício para muitas vozes., 215 à 221. Rio de Janeiro: Prieto Produções Artísticas, 2011. p. 125;

SPOLIN, Viola. Improvisação para o teatro. São Paulo: Perspectiva, 2005. p. 154;

STORT, Eliana Viera Ribeiro. "Cultura, Imaginação e Conhecimento: A educação e a formalização da experiência." Tese de Doutorado. Campinas: UNICAMP, 1989. p. 141/207;

SUNDERLAND, Margot. O valor terapeutico de contar histórias: para as crianças; pelas crianças. São Paulo: Cultrix, 2005. p. 153;

TAHAN, Malba. A arte de contar histórias. Rio de Janeiro: Conquista, 1964. p. 70/ 91/178;

TATAR, Maria. Contos de fadas: edição comentada e ilustrada. Rio de Janeiro: Zahar, 2004. p. 152/175/176/177;

TIBAJI, Alberto. Teatro valor e pluralidade: rumo a uma política e a uma estética do popular. In RABETTI, Beti. Teatro e comicidade 3: Facécias, faceirices e divertimentos. Rio de Janeiro: 7letra, 2010. p. 35;

TIERNO, Giuliano. "Pegadas reflexivas acerca da arte de contar histórias." In: A arte de contar histórias: abordagem poética, literária e performática., por Giuliano TIERNO, 13 à 28. São Paulo: Ícone, 2010. p. 70/97/113/129/133; 
TITZMANN, Vera Maria. Literatura infantil brasileia: um guia para professores e promotores de leitura. Goiânia: Cânone, 2008. p. 67;

TURCHI, Maria Zaíra. In: TURCHI, M. Z., e V. M. T. SILVA. O estatuto da arte na literatura infantil e juvenil. Goiânia: Cegraf/UFG, 2002. p. 184;

VAZ, Henrique Lims. Cultura e Universidade. Petrópolis: Vozes, 1966. p. 30/174;

VELOSO, Jorge das Graças. A vista do divino. Brasília: Thesaurus, 2009. p. 83/84;

VYGOTSKY, Lev S. Imaginación y el arte en la infância. México: Hispanicas, 1987. p. $137 / 191$;

YUNES, Eliana. "Contar para ler - A arte de contar histórias e as práticas de leitura." In: Aartte de encantar: o contador de histórias contemporâneo e seus olhares., por Fabiano \& GOMES, Lenice MORAES, 59 à 78. São Paulo: Cortez, 2012. p. 79/94/103/119/157/185/209/210/215;

ZARATIN, Terezinha Nackéd. Comunicação verbal - Educação vocal. São Paulo: Paulus, 2010. p. 214/219;

ZUMTHOR, Paul. A letra e a voz. São Paulo: Companhia das letra, 1993. p. 209/ 211/213/230;

ZUMTHOR, PAUL. Performance, recepção, leitura. São Paulo: Cosac Naify, 2007. p. 210;

ZURK, Bernardo. "Imagina enquanto eu te conto." In: Educação e Arte: linguagens artísticas na formação humana., por Celdon e MOREIRA, Janini FRITZEN, 119 à 130. Campinas SP: Papirus, 2008. p. 107/140/142/151. 


\section{ANEXOS}

Anexo 1 - quadro de recursos para se contar histórias;

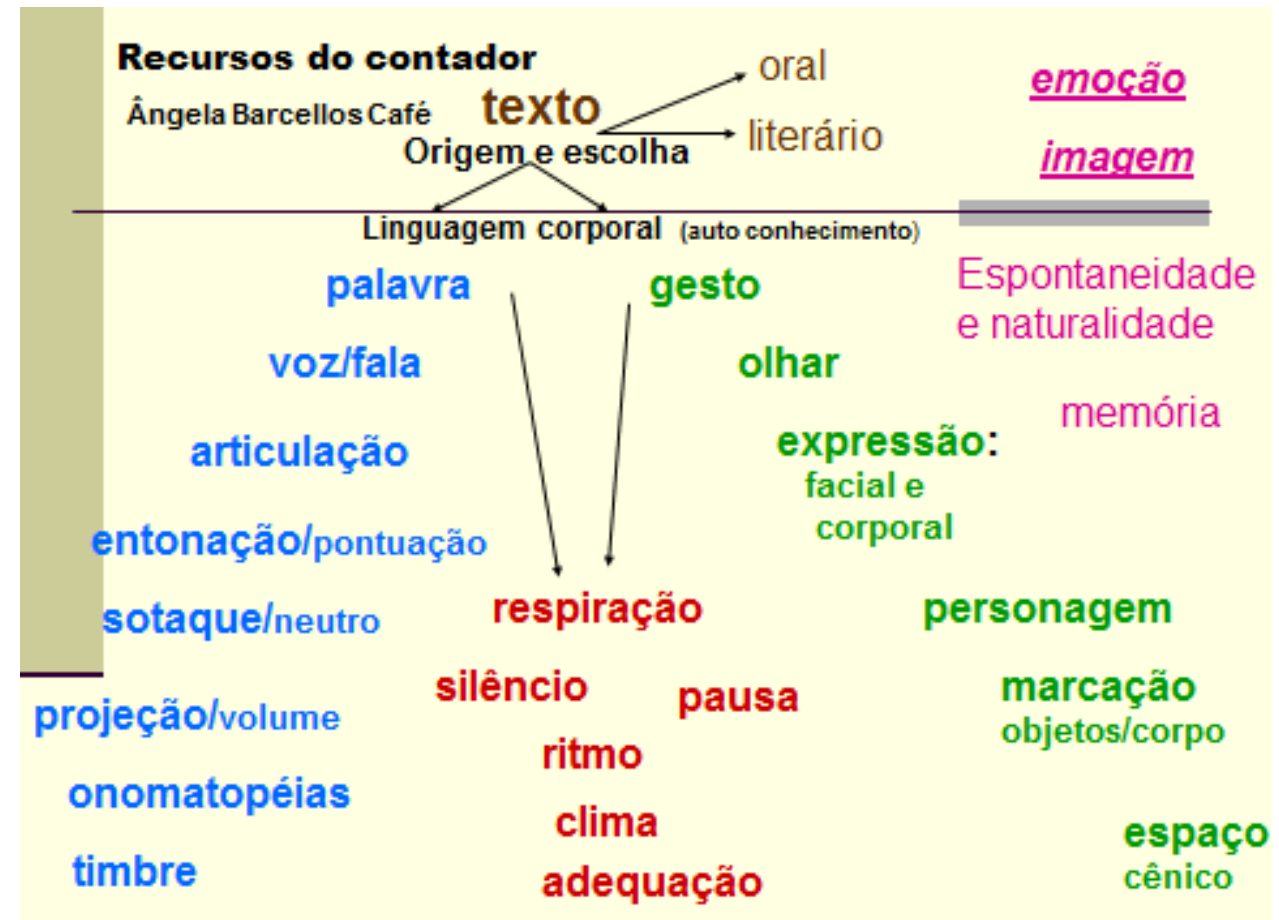


Anexo 2 - algumas histórias orais da pesquisa de Pirenópolis.

DONA CAROCHINHA - versão oral

Versão original: S. Ico

Contadora: Fernanda Fonseca (aluna de Artes Cênicas) e Ângela Barcellos

Um dia Dona Carochinha resolveu fritá uns bolinho, uns trem lá, ela colocô óleo na frigideira e começô a subi um chero, mais um chero tão bom que atiçô a curiosidade de Don Rato. Então, ele subiu pelo telhado pra ver o que Dona Carochinha 'tava fazeno. Só que, de repente, ele caiu dentro da panela quente. Aí Dona Carochinha ficô chorona:

- Ai meu Deus do céu! Que eu faço agora? - Sentou perto da porta e num parô mais de chorá.A porta ficô curiosa, né? E resolveu perguntá:

- O que aconteceu, Dona Carochinha?

- Don Rato caiu dentro da panela quente, agora eu num paro de chorá.

- Então, em luto a Don Rato, eu vou bater - bater.

Tinha uma porteira lá perto. Ela viu a agitação da porta e resolveu perguntá:

- Porque bate - bate, porta?

- Em luto a Don Rato, que caiu dentro da panela quente, Dona Carochinha não para de chorá e eu bato - bato.

- Em sinal de luto a Don Rato, eu vou abri e fechar.

Tinha um passarinho que era acostumado a descansá poso na porteira, só que naquele dia ele não deu conta, porque a porteira não parava queta. Então, ele resolveu perguntá:

- Porque abre e fecha, porteira?

- Em luto a Don Rato, que caiu dentro da panela quente, Dona Carochinha não pára de chorá, a porta bate - bate e eu resolvi abri e fechar.

- Em Sinal de luto a Don Rato, eu vou ficar sem minhas penas.

Quando o passarinho tentô ir para seu ninho, que ficava em cima de uma árvore ali perto, o coitadinho não conseguiu, porque, afinal, ele 'tava sem suas penas não conseguia voá. A árvore perguntô:

- Porque está sem suas penas, hein, passarinho? 
- Em sinal de luto a Don Rato, que caiu dentro da panela quente, Dona Carochinha não pára de chorá, a porta bate - bate, a porteira abre e fecha e eu resolvi ficar sem minhas penas.

- Em sinal de luto a Don Rato, eu vou ficar sem minhas folhas.

Um boi era acostumado a aproveitar a sombrinha da árvore, quando viu que ela não tinha mais sombra, resolveu perguntá:

- O que 'tá aconteceno, árvore, que você 'tá sem suas folhas?

- Em sinal de luto a Don Rato, que caiu dentro da panela quente, Dona Carochinha não pára de chorá, a porta bate - bate, a porteira abre e fecha, o passarinho ficô sem suas penas e eu resolvi ficar sem minhas folhas.

- Em sinal de luto a Don Rato eu vou perder os chifres.

Quando o boi foi no rio bebê água, ele estranhô e resolveu perguntá:

- O que aconteceu com seu chifre, boi?

- Em sinal de luto a Don Rato, que caiu dentro da panela quente, Dona Carochinha não pára de chorá, a porta bate - bate, a porteira abre e fecha, o passarinho ficô sem as penas, a árvore ficô sem as folhas e eu perdi os chifres.

- Em sinal de luto a Don Rato, eu vou secar.

A pedido da mãe, uma menina foi buscá água no rio e, quando chegou lá e viu ele seco, resolveu perguntá:

- Porque você secô, rio?

- Em sinal de luto a Don Rato, que caiu dentro da panela quente, Dona Carochinha não pára de chorá, a porta bate - bate, a porteira abre e fecha, o passarinho ficô sem as penas, a árvore ficô sem as folhas, o boi perdeu os chifres e eu resolvi secar.

- Em sinal de luto a Don rato, eu vou quebrar meu pote.

Quando chegô em casa, a mãe da menina estranhô que ela não tinha levado a água e perguntô:

- Cadê a água que te pedi?

- Em sinal de luto a Don Rato, que caiu dentro da panela quente, Dona Carochinha não pára de chorá, a porta bate - bate, a porteira abre e fecha, 0 passarinho ficô sem as penas, a árvore ficô sem as folhas, o boi perdeu os chifres, o rio secô e eu resolvi quebrar a pote.

- E o que eu tenho a ver com isso? Nem conheço esse tal de Don Rato. Você vai já para seu quarto de castigo e eu vô ali pegá uma vara pra te batê, porque, 
agora, como que eu vô afogá meu arroz?

A menina obedeceu, né? E foi pro quarto. Quando é fé, começa um redemoinho do lado dela. Era o Saci, rino e falano assim:

- Vai mais... Isso é pro cê largá mão de ser fofoqueira e falá que sou eu que pego os bolo. Fui eu que inventei essa história toda e, se ocê prometê que vai guardá um pedaço de bolo pra mim todo dia, eu desfaço essa história. Conto ela de trás pra frente e ocê num apanha.

A menina mais que na hora concordô. E sai sol, entra lua e o saci 'tá contano essa história todinha de trás pra frente. Danado esse saci. não?!

$$
*_{\text {fim }}^{*}
$$

MOÇA TRÔXA - versão oral

Versão original: D Benta

Contadora: Larissa Gebrim (aluna de Artes Cênicas) e Ângela Barcellos

Tinha um casal e o pai da moça trabalhava com esses trem de construção, tinha enxó, martelo, esses trem, ferramenta tudo pinduradu na parede. Aí o casal ta lá namoranu já tinha uns oito meses de namoru e o rapaz resolveu pedi a moça em casamentu. A moça danou a chorá e a mãe dela veio querenu sabê que qui ela tanto chorava e ela disse:

_ É que eu vou casá, vou ter um fii e quando ele tivé andano esses trem espindurado na parede vai caí na cabeça dele e ele vai morrê.

A mãe garrô a chorá também falanu:

_ Meu netim vai morrê.

Com essa choradeira toda o pai vei de lá querenu saber que qui tava acontecenu e contaram o mesmo detalhe da história e ele garrô a chorá juntu.

O rapaz dizia que tinha entradu numa fria e que agora tinha que dar um jeito de iscapulir desse povu. Então ele falo pra moça que ia dá uma volta pelo mundo e quando encontrar gente mais trôxa que ela, ele vorta pra casá. Ela trôxa mesmo, concordô e ainda perguntô do que qui ele pricisava. Ele disse que quiria uma agulha e um galo e ela entregô pra ele os dois. 
Cheganu na primeira casa pra pedir um pouso ele pediu pra mulher guardá a agulha debaixo da asa do galo. Quando é lá pras meia-noite o galo cantô e a agulha sumiu. De manhã quando ele foi procurá a agulha, cadê a agulha? Ele começo a fazer papeu de louco dizenu:

_ Ai minha agulha eu não vivo sem minha agulha.

E a mulher disse que pagava déis mil réis pela agulha. Ele pegô o dinheiro e continuo a andar com o galim debaixo do braço.

Quando ele chego na próxima casa pra pedir um pouso o povo falo pra ele que eles tem a moda de lá pras meia-noite cantá pra chamá o dia. O rapaz falô que não que ele tem um bichim que chama o dia e que ele vende pra eles. Eles assim compraram o bichim dele.

Na próxima casa que ele foi pedir pouso tava sainu uma leitoa com cinco leitãozim e ele começo a falar:

_ Ai minha mãe!!! Minha mãe...

A mulher então pergunto se a leitoa é mãe dele porque se for ela tinha dado déis leitãozim e eles já tinham comido cinco. O rapaz falô que ela vai ter que pagá pelos irmãozim dele, que ela comeu. Essa mais trôxa que todas!... Pagô com medo de ser presa porque comeu os irmãozim dele, meu Deus.

Cheganu na próxima casa ele começo a falar:

_ Ai meu pai do céu.

E a moça pergunto pra ele se ele veio do céu e ele disse que sim que veio do céu. Ela pediu notícias do marido que já tinha morrido fazia uns dois anos e ela nem tinha noticias dele.

O rapaz falo que ele tá lá no céu peladim que as roupa dele cabou tudo que tava precisado de um dinheirinho de um garriado. A mulher foi e pego as roupa, do segundo marido, a mula arriada, um dinheiro e deu pra ele levar.

Quando deu umas cinco da tarde o marido chego e ela foi contá que teve notícias do marido falecido e ele fico enfurecido dizenu que era ladrão que tinha roubado eles tudo e que ia atrás dele. O rapaz ficou desconfiado que o marido vinha atrás dele escondeu os trem dele tudo no mato e ficou peladim. O marido foi chegando e pergunto pro rapaz se ele tinha visto um ladrão que disse que tinha vindo do céu e ele disse que não porque pro céu a gente só ia pelado e que ele mesmo tava tentando ir. 
O marido querendo ir pro céu também tirou a roupa e pediu pro rapais vigiá as coisas dele. O rapais disse pra ele que pra i pro céu ele tinha que i por lá e ele foi $\mathrm{i}$ indo, o rapaz então pego as coisas dele tudo e foi embora, vortanu pra casa com a moça porque tinha visto que existia gente mais trôxa que ela nu mundo.

\section{$*_{\mathrm{fim}}^{*}$}

CAÇANDO UMA ESPOSA - versão oral

Versão original: Safia - 06/ 08/ 2000.

Contador: Taiom Tawera (aluno de Artes Cênicas)

Praticamente se chamava priguiça o meninu... Tô te falanu moço, o menino era priguiçoso dimais... Moço o meninu durmia de olhu abertu porque tinha priguiça de fechá... Moço, a coisa que ele mais tinha priguiça era de conversá, tu a de vê... $\mathrm{A}$ mãe dele via aquilo, e num guentava mais... Aí um dia ela falô assim:

_ Oh... meu filho! Vai arranjá uma namorada, fica aí toda vida sozinho, num pega nem aranha que já carrega a rede armada. Ocê tá na hora de se casá. O seus irmão tudo já se casô... ocê num vai tê eu toda vida não!

O danado olhô pra ela assim e disse:

_Hum, hum...

Pegô a violinha dele, deitô na rede, colocô as perna pra cima e foi tocá... A mãe dele ficô nervosa dum tan,tan cum aquilo... Todo dia falava as coisa, e nada do menino dá jeito. Então ela passô a mão num porreti pra dá nele. Quano ele viu saiu correnu, tropeçô, achô uma agúia e gritô:

_ Achei meu casamento!

_ Isso lá é casamento? Pocaria...

_ É sim, um casamento dos bão. Olha aqui minha agúia! A senhora me prepara umas matulinha aí, e há de vê meu casamento.

Mesmo sem concordá a mãe preparô a comida, e colocô numas latas, pra ele carregá. Aí o menino começô a se camuflá de feiúra, rapaiz, tu num há de vê? Ele fez uma pasta de mel, açuca e pó de cerragi e tacô na cara, nos braçu, passô ni tudo, passô ni tudo... num tinha quem disconfiáce... Aí ele foi embora, levanu a agúia, e as lata de matula tudo batenu fazenu aquele baruio, tan, tan, tan... Num 
tinha quem aguentace... Não rapaiz, e ele ainda vinha cantarolanu, mais num dava pra iscutá direito o que ele cantava, por causa do barúio das lata de matula:

_ Eu vim de tan, tan, levei pra tan, tan. Eu vim de tan, tan, levei pra tan, tan...

Dispois de muito andá, já di tardinha ele chega numa fazenda, bate palma lá... e diz:

_ Me dá um pôso?

Mais quanu a muié abriu a janela e viu aquele home todo isquisito, ela ficô com medo dimais da conta, e começô a fechá a janela bem devagarzim pra ele num percebê, assim ele pensava que num tinha ninguem ali. Mais ele percebeu e falô assim:

_ O pôso num é pra mim não! É pra minha agúia, eu mesmo vô dormi ali no mato. É porque ela tá custumada a dormi de bacho da asa do galo. Dá pôso pra minha aguinha dá?

A muié aceitô. Ela colocô a agúia na asa do galo da manera qui ele falô.

No outro dia ele envem.

_ Eu vou buscar, meu casamento! Eu vim de tan, tan levei pra tan, tan, eu vim de tan,tan levei pra tan,tan... Cadê minha agúia?

Quano a dona da fazenda foi buscá, quem disse que ela encontrô? O galo rapaiz bateu as asas de manhã e agúia no palheiro.

Então ele falô:

_ Já que sumiu minha agúia, ou mim dá um galim desse o a vida docê?!

A muié mais que depressa disse:

_ O que é um galim desse pra mim? Pode levá.

Então ele pegô o galo e saiu cantarolando:

_ Eu vou buscar, meu casamento! Eu vim de tan,tan levei pra tan,tan, eu vim de tan,tan levei pra tan,tan... Chegô na segunda fazenda. Quem viu ele primeiro foi uma menininha e logo foi avisá pra mãe:

_ Mainhê? Tem um bicho feio pedindo um pôso.

Dispois de dormir no mato cum aquele mel no corpo, o menino voltô ainda mais feio, cheio de pedrinha pelo corpo, fazendo cada calombo nos braço... O mel da cara escorreu ficano aquela cara torta empolada, nan só veno mesmo viu...?! Quano a mãe da menina foi vê, quase dá um ataque. A coitada pensô que ele num era nem gente de tão feioso que tava. E ela só não saiu correnu porque as perna começô a tremê e ela teve que ficar ali mesmo. 
_ O pôso num é pra mim não, é pro meu galim, eu mesmo vou dormir ali no mato. É que ele tá custumado a dormir no curral, juntim cus boi. Dá pôso pro meu galo?

Disse o deformado do rapaiz... A muié aceito, ela colocô o galo no curral da maneira que ele falô. No outro dia de manhã ele envem:

_ Cadê meu galim?

Quando a dona da fazenda foi buscar o galo, quem disse que ela encontrô? Na verdade encontrá encontrô, só que num tava vivo. Os boi mais as vaca matô ele de noite.

Então ele falô assim:

_ Já que matou meu galim, ou me dá um gadim desse ou a vida docê?

Ela mais que dipressa respondeu:

_O que qui é um boi desse pra mim? Pode levá.

Então ele pegô o boi e saiu cantarolando:

_ Eu vou buscar, meu casamento! Eu vim de tan,tan levei pra tan,tan, eu vim de tan,tan levei pra tan,tan...

E ele foi tocanu o boi dele pelo caminho até que encontrô dois homi carreganu um caixão. Aí ele perguntou:

_Que é?

Um dos moço respondeu:

_ É uma moça que morreu, ela bebeu venenu.

_ Ocêis que trocá essa moça pelo boi?

Aí, eles pensaro assim: num tinha ninguém lá perto pra contá o trem que eles feiz, os dois podia vendê o boi e reparti o dinheiro. Então eles aceitaro negociação.

Ele pegô a moça nos braço e saiu cantarolando:

_Eu vou buscar, meu casamento! Eu vim de tan, tan levei pra tan, tan, eu vim de tan, tan levei pra tan, tan...

Dispois de muito andá, ele chegou numa fazenda cheia de carro de boi, mas um monte mesmo de moça nesses carro, tinha mais ou menos uns dois ou treis...

Quano ele apareceu na frente delas, elas ficô assustada qui nem calango, sem sabê pra onde corre. Aí logo o pai das moça aproximô e eles foi prosiá.

_ Eu quiria um pôso, pra minha filhinha. Eu mesmo vou dormir ali no mato, dá um pôso pra minha filhinha dá? Ela tá tão amuadinha, óia aqui já até durmiu nos 
meus braços. É porque ela tá custumada a dormir sozinha, sem ninguém fica conversanu com ela.

O Homi aceitô, e deu o pôso pra menina.

No outro dia de manhã ele envem:

_ Cadê minha fia?

Quano o dono da fazenda foi buscá, quem disse que ele encontrô? Na verdade, encontrá encontrô, só que num tava viva não.

Então o danado do rapaiz disse:

_ Já que matou minha filha ou você me dá uma moça dessas pra eu casá, ou a vida dôces tudão aí?!!!

Aí o homi mais que depressa falô assim:

_ O que qui é uma moça dessa pra mim, pode levá.

O problema é que as moça num queria í com o rapaiz, assaltadô de beleza.

Eu sei que as minina aprontaram um impurra impurra, e a caçulinha, a mais bunitinha das moça, tropeçô no rumo do melado do rapaiz, que pegô a minina antis de cair no chão... aí ela olhou pra ele e disse ao pai:

_ Eu caso cum ele pai...

Aí o danado do rapaiz pegou um taquim de água que tinha na cumbuquinha tacô na cara, tirô o melado do rosto e mostrou sua beleza, aí as irmã da moça se ruêro...

E o danado ainda saiu contarolanu:

Eu busquei meu casamento! Eu vim de tan,tan levei pra tan,tan e voltei pra $\tan , \tan \ldots$

E foi isso e tá acabádu...!!!!!!!!!!!!!!!!!!!!!!!! 